Keywords: DWPF, Tank 48, FBSR, WAC coal limit, off-gas flammability

Retention: Permanent

\title{
DWPF Coal-Carbon Waste Acceptance Criteria Limit Evaluation Based on Experimental Work (Tank 48 Impact Study)
}

D. P. Lambert

A. S. Choi

October 2010

Savannah River National Laboratory Savannah River Nuclear Solutions, LLC Aiken, SC 29808

Prepared for the U.S. Department of Energy under contract number DE-AC09-08SR22470.

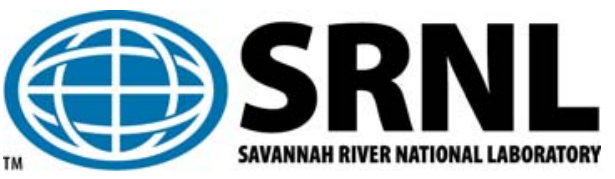


SRNL-STI-2010-00589

Revision 0

\section{DISCLAIMER}

This work was prepared under an agreement with and funded by the U.S. Government. Neither the U.S. Government or its employees, nor any of its contractors, subcontractors or their employees, makes any express or implied:

1. warranty or assumes any legal liability for the accuracy, completeness, or for the use or results of such use of any information, product, or process disclosed; or

2. representation that such use or results of such use would not infringe privately owned rights; or

3. endorsement or recommendation of any specifically identified commercial product, process, or service.

Any views and opinions of authors expressed in this work do not necessarily state or reflect those of the United States Government, or its contractors, or subcontractors.

\section{Printed in the United States of America \\ Prepared for \\ U.S. Department of Energy}




\section{REVIEWS AND APPROVALS}

\section{AUTHORS:}

D. P. Lambert, Process Technology Programs

Date

A. S. Choi, Engineering Process Development

Date

TECHNICAL REVIEW:

M. E. Stone, Process Technology Programs

Date

B. R. Pickenheim, Process Technology Programs

Date

F. G. Smith, Process Modeling and Computational Chemistry

Date

APPROVAL:

C. C. Herman, Manager

Date

Process Technology Programs

A. B. Barnes, Manager

Date

Engineering Process Development

S. L. Marra, Manager

Date

Environmental \& Chemical Process Technology Research Programs

R. T. McNew, Manager

Date

Tank 48 Projects

J. E. Occhipinti, Manager

Date

Waste Solidification Engineering 


\section{EXECUTIVE SUMMARY}

This report summarizes the results of both experimental and modeling studies performed using Sludge Batch 10 (SB10) simulants and FBSR product from Tank 48 simulant testing in order to develop higher levels of coal-carbon that can be managed by DWPF. Once the Fluidized Bed Steam Reforming (FBSR) process starts up for treatment of Tank 48 legacy waste, the FBSR product stream will contribute higher levels of coal-carbon in the sludge batch for processing at DWPF. Coal-carbon is added into the FBSR process as a reductant and some of it will be present in the FBSR product as unreacted coal.

The FBSR product will be slurried in water, transferred to Tank Farm and will be combined with sludge and washed to produce the sludge batch that DWPF will process. The FBSR product is high in both water soluble sodium carbonate and unreacted coal-carbon. Most of the sodium carbonate is removed during washing but all of the coal-carbon will remain and become part of the DWPF sludge batch.

A paper study was performed earlier to assess the impact of FBSR coal-carbon on the DWPF Chemical Processing Cell (CPC) operation and melter off-gas flammability by combining it with SB10-SB13. The results of the paper study are documented in Ref. 7 and the key findings included that SB10 would be the most difficult batch to process with the FBSR coal present and up to $5,000 \mathrm{mg} / \mathrm{kg}$ of coal-carbon could be fed to the melter without exceeding the off-gas flammability safety basis limits.

In the present study, a bench-scale demonstration of the DWPF CPC processing was performed using SB10 simulants spiked with varying amounts of coal, and the resulting seven CPC products were fed to the DWPF melter cold cap and off-gas dynamics models to determine the maximum coal that can be processed through the melter without exceeding the off-gas flammability safety basis limits. Based on the results of these experimental and modeling studies, the presence of coal-carbon in the sludge feed to DWPF is found to have both positive (+) and negative (-) impact as summarized below:

- Coal-carbon is a melter reductant. If excess coal-carbon is present, the resulting melter feed may be too reducing, potentially shortening the melter life. During this study, the Reduction/Oxidation Potential (REDOX) of the melter could be controlled by varying the ratio of nitric and formic acid.

- The addition of coal-carbon increases the amount of nitric acid added and decreases the amount of formic acid added to control melter REDOX. This means that the CPC with the FBSR product is much more oxidizing than current $\mathrm{CPC}$ processing. In this study, adequate formic acid was present in all experiments to reduce mercury and manganese, two of the main goals of CPC processing.

- Coal-carbon will be oxidized to carbon dioxide or carbon monoxide in the melter. The addition of coal-carbon to the FBSR product will lead to approximately $55 \%$ higher offgas production from formate, nitrate and carbon due to the decomposition of the carbon at the maximum levels in this testing. Higher offgas production could lead to higher cold cap coverage or melter foaming which could decrease melt rate. No testing was performed to evaluate the impact of the higher melter offgas flow.

+ The hydrogen production is greatly reduced in testing with coal as less formic acid is added in CPC processing. In the high acid run without coal, the peak hydrogen generation was 15 times higher than in the high acid run with added coal-carbon. 
+ Coal-carbon is a less problematic reducing agent than formic acid, since the content of both carbon and hydrogen are important in evaluating the flammability of the melter offgas. Processing with coal-carbon decreases the amount of formic acid added in the $\mathrm{CPC}$, leading to a lower flammability risk in processing with coal-carbon compared to the current DWPF flowsheet.

+ The seven SB10 formulations which were tested during the bench-scale CPC demonstration were all determined to be within the off-gas flammability safety basis limits during the $9 \mathrm{X} / 5 \mathrm{X}$ off-gas surge for normal bubbled melter operation. The concentration of coal-carbon in these baseline melter feeds varied widely from 0 to $17,863 \mathrm{ppm}$, depending on the acid addition strategy used and the extent to which the required reductant (formic acid) was replaced with coal-carbon. All baseline feeds were redox-adjusted and three of them contained TOC higher than the current theoretical TSR limit of $18,900 \mathrm{ppm}$.

- Additional coal-carbon was then added to each baseline feed until the calculated off-gas flammability equaled the safety basis limit of $60 \%$ of the LFL at the peak of off-gas surge ("max-coal"). In doing so, however, no counterbalancing nitrate was added, thus simulating the scenario where slugs of coal enter the melter as a result of uneven distribution of coal in the slurry. The results of these "max-coal" feed simulations showed that the maximum coalcarbon concentration that can be processed through the DWPF melter without exceeding the safety basis limits varies from 3,400 ppm (SB10-8) to 19,032 ppm (SB10-1). The resulting TOC exceeded the current TSR limit in all max-coal feeds except SB10-8, whose TOC was just below the TSR limit.

- The results of flammability assessment also showed that the theoretical maximum coalcarbon limit for DWPF melter should occur when the formic acid addition is kept to a minimum, as required by the reduction of $\mathrm{Hg}$ and $\mathrm{Mn}$ and the destruction of nitrite, while maintaining as high a nitrate level as possible at a given target redox.

It should be noted that the maximum coal-carbon concentrations stated above represent the theoretical limits and the actual field limits of coal-carbon will be lower since appropriate analytical and instrument uncertainties must be subtracted from the theoretical limits.

Recommendations:

1. The results of this feasibility analysis indicate that the processing of SB10 sludge together with the FBSR product using a coal-carbon concentration of $9.5 \mathrm{wt} \%$ total solids basis and SWPF products is possible in the CPC. However, since every sludge batch has a different composition, this limit should be reevaluated with each new sludge batch as part of the sludge batch qualification program.

2. Minimize the coal-carbon content in the FBSR product. Minimizing the coal-carbon concentration will also limit the nonradioactive impurities added in waste processing (coal ash, carbon, sulfur, etc.).

3. Develop a method to measure the carbon concentration in washed sludge and CPC slurries. Analytical Development (AD) has been unable to accurately measure the carbon concentration with existing instruments and methods. Understanding the concentration of the carbon will be critical in DWPF processing.

4. Experimentally assess the impact of FBSR product on melt rate. Melt rate was not measured as part of this study, nor was the optimum frit used during this study.

5. Use a melter for in-situ sampling or post-mortem (destructive) analysis to assess the potential for localized reduction, the formation of metallic precipitates, and/or possible interactions of reduced species (such as nickel sulfides) on materials of construction.

6. Testing of the sludge wash material that was collected during sludge preparation should be used in testing to determine whether this large quantity of sodium carbonate produced 
during sludge washing will impact the HLW evaporators or Waste Tanks. The decanted supernate from washing SB10-B simulant has been collected and retained.

7. This preliminary study should be reassessed if a new CPC flowsheet is defined and when the FBSR product stream is finalized. 


\section{TABLE OF CONTENTS} ix

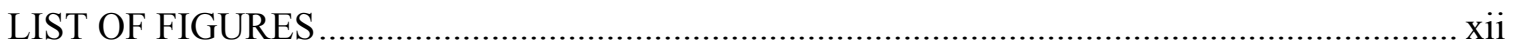

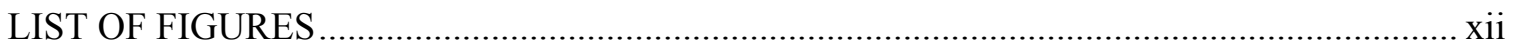

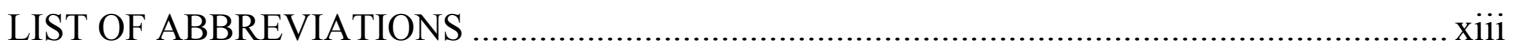

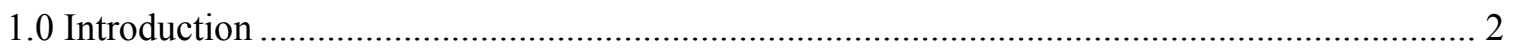

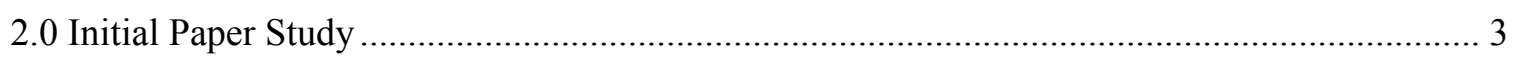

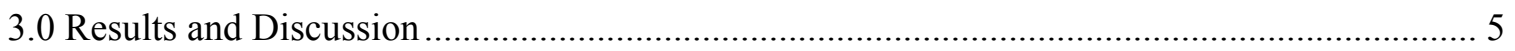

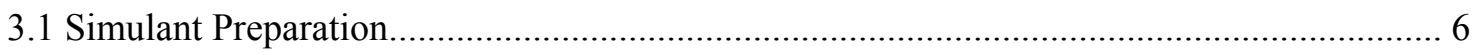

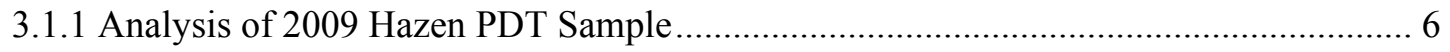

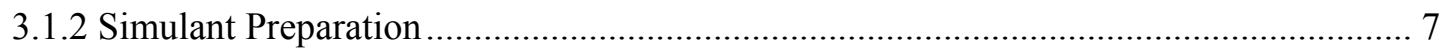

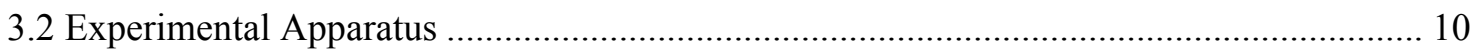

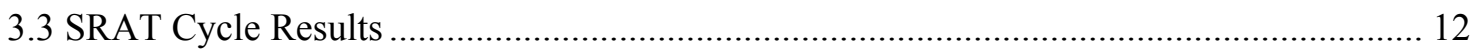

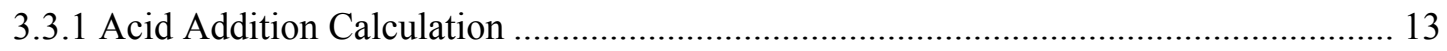

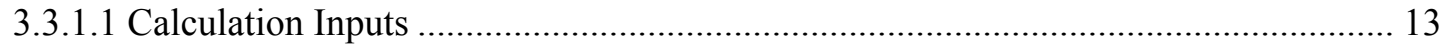

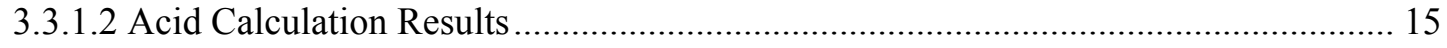

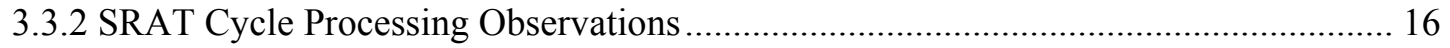

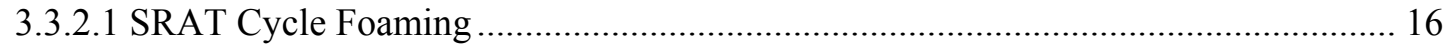

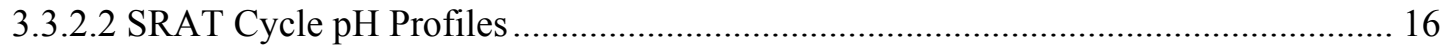

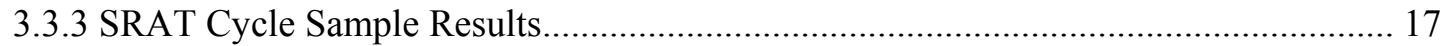

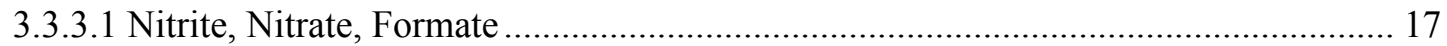

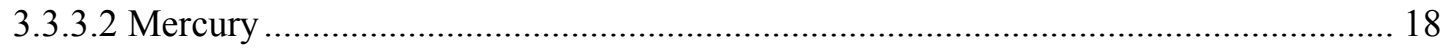

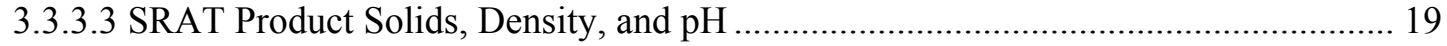

3.3.3.4 SRAT Slurry and Filtrate Sample ICP-AES Results................................................. 19

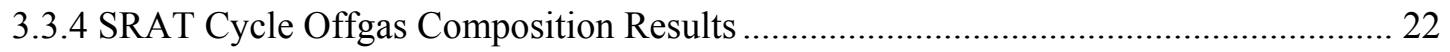

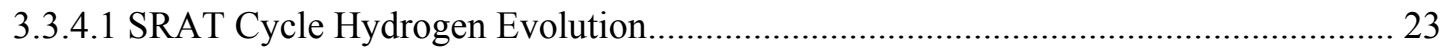

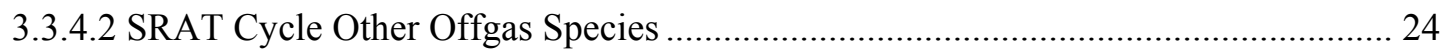

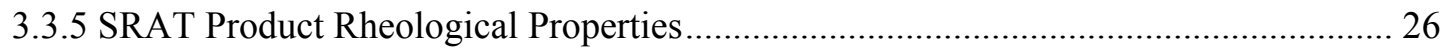

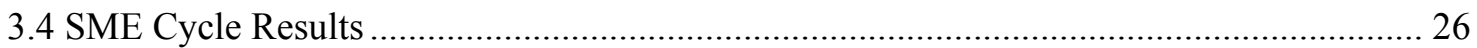

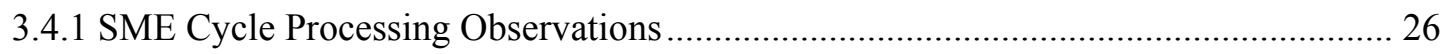

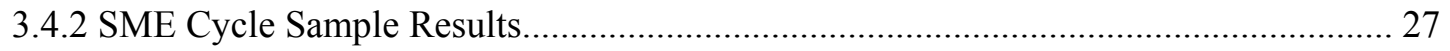

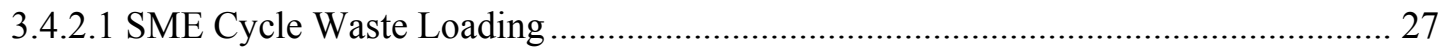

3.4.2.2 SME Cycle Anion Concentrations and Anion Conversion Results ........................... 28

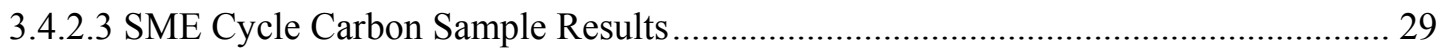


3.4.2.4 SME Sample Solids, Density and pH Results .......................................................... 29

3.4.2.5 SME Slurry and Filtrate Sample ICP-AES Results and Calculated Percent Soluble. 30

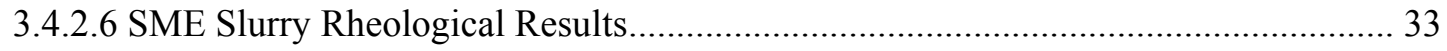

3.4.3 SME Cycle Offgas Composition Results ……............................................................... 34

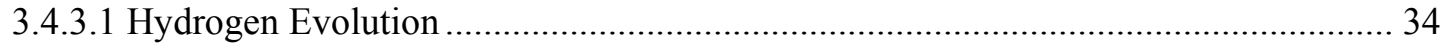

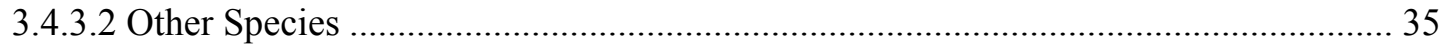

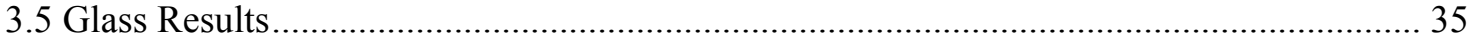

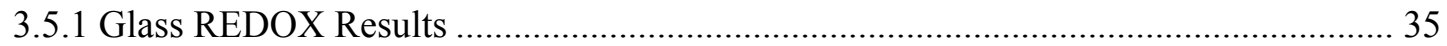

3.5.2 SME Product MAR Assessment of Sectioned Glass Samples ...................................... 36

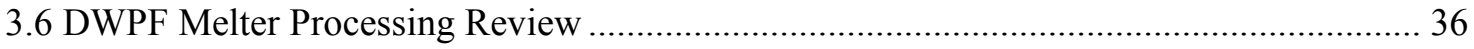

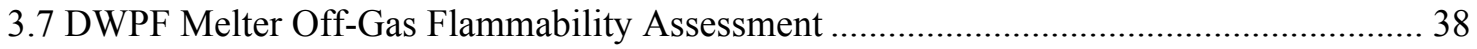

3.7.1 Flammability Assessment of Baseline Feeds ............................................................... 39

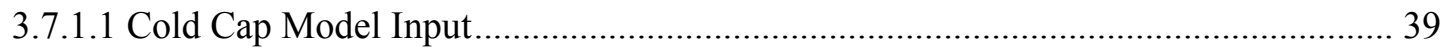

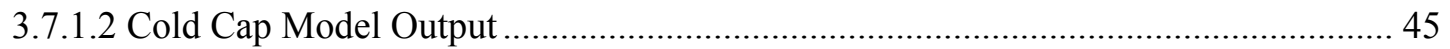

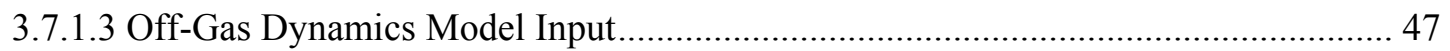

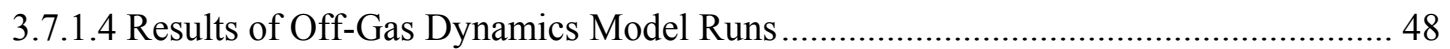

3.7.2 Flammability Assessment of Max-Coal Feeds............................................................. 50

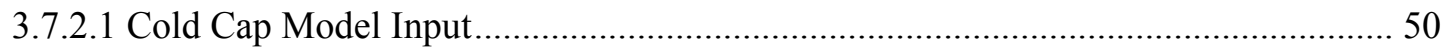

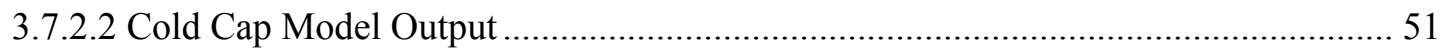

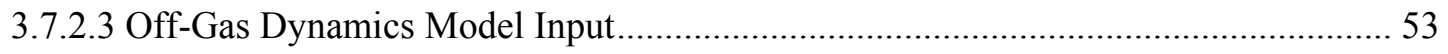

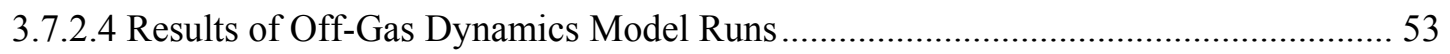

3.8 Impact of FBSR Stream on Tank Farm and Other Processing Facilities............................ 56

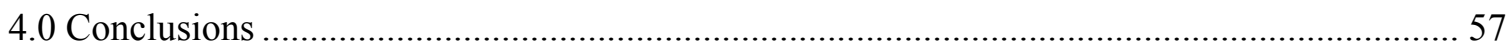

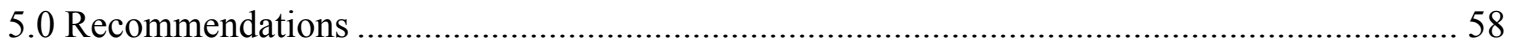

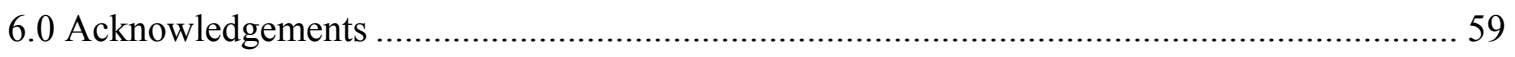

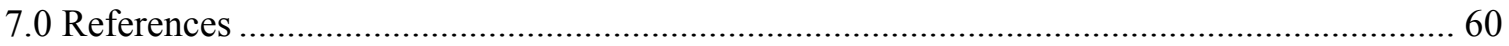

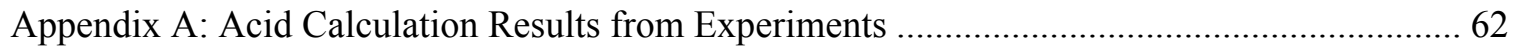

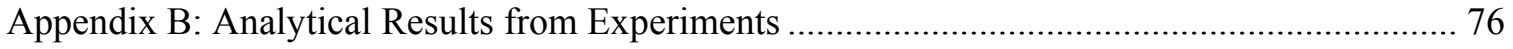

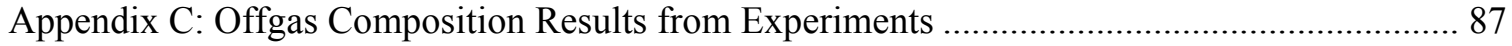

Appendix D: Predicted Compositions of SB10 Baseline Melter Feeds ........................................ 92 


\section{LIST OF TABLES}

Table 2-1. DWPF Processing Streams during FBSR Processing ................................................. 4

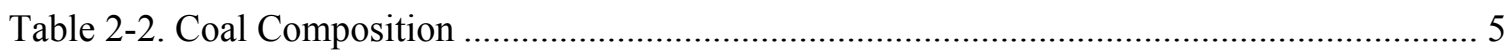

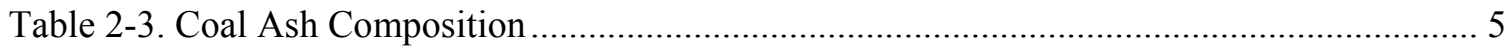

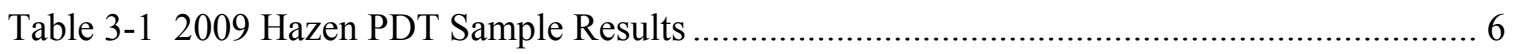

Table 3-2 Simulant Composition for Flowsheet Testing ........................................................... 9

Table 3-3 Trim Chemical Additions, wt \% on Total Solids Basis .............................................. 9

Table 3-4 Calculated Blended Sludge Composition............................................................... 10

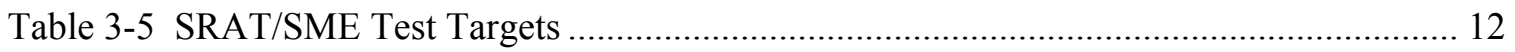

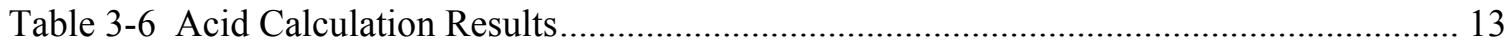

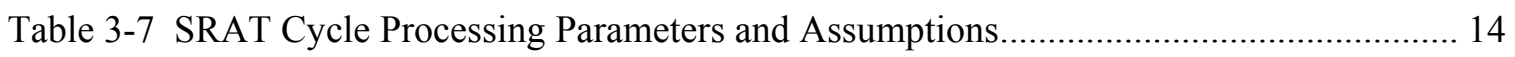

Table 3-8 SME Processing Parameters and Assumptions.......................................................... 15

Table 3-9 Selected Process Values for Testing .......................................................................... 16

Table 3-10 SRAT Product Anion Concentration from Tests, mg/kg slurry ............................... 17

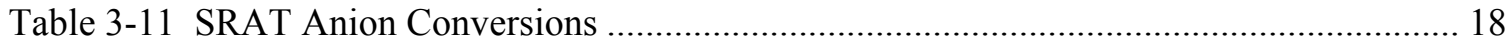

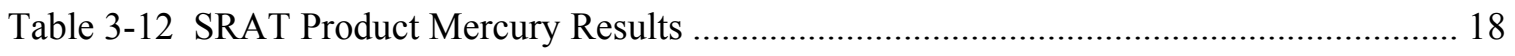

Table 3-13 SRAT Product Solids, Density, and pH Results ..................................................... 19

Table 3-14 SRAT ICP-AES Slurry Results, wt \% Calcined Solids Basis................................... 20

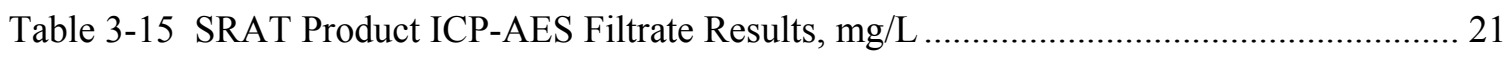

Table 3-16 SRAT Product Percent of ICP-ES Elements Soluble................................................ 22

Table 3-17 SRAT Cycle Hydrogen Peak Generation Rate ……................................................ 24

Table 3-18 SRAT Cycle Nitrous Oxide and Carbon Dioxide Peak Generation Rates................. 25

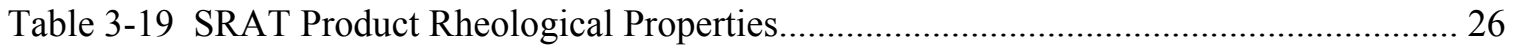

Table 3-20 SME Product Lithium Oxide Concentration and Waste Loading Results ................. 28

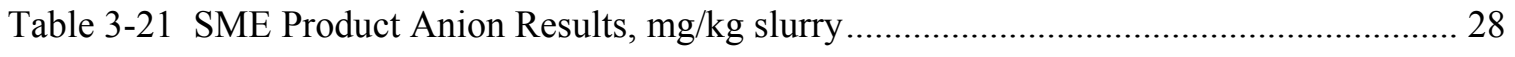

Table 3-22 SME Product Anion Conversions (\%) ................................................................... 28

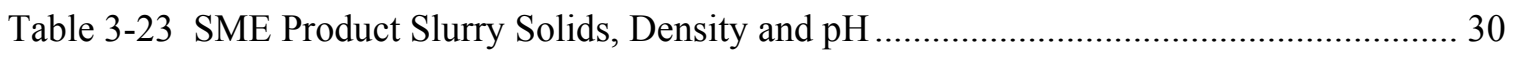

Table 3-24 SME ICP-AES Slurry Results, wt \% Calcined Solids Basis....................................... 31 
Table 3-25 SME Product ICP-AES Filtrate Results, mg/L ..................................................... 32

Table 3-26 SME Product Percent of ICP-AES Elements Soluble ................................................. 33

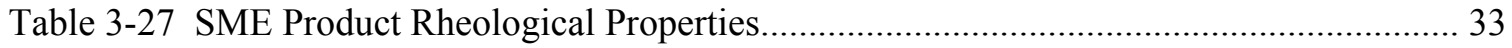

Table 3-28 SME Cycle Hydrogen Peak Generation Rate …..................................................... 35

Table 3-29 SME Cycle Nitrous Oxide and Carbon Dioxide Peak Generation Rates, $\mathrm{lb} / \mathrm{hr}$......... 35

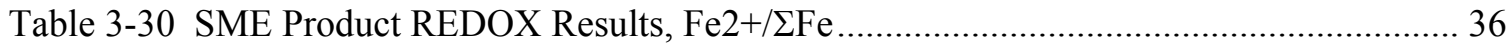

Table 3-31. Results of Charge Balance of SB10 SRAT Products............................................... 39

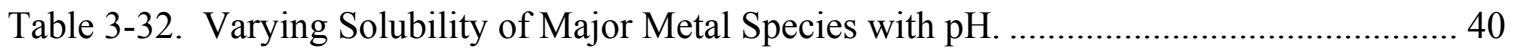

Table 3-33. Recipe for Coal-carbon Addition to SB10 SRAT Product. ........................................ 40

Table 3-34. 4-Stage Cold Cap Model Input for SB10-1 at 1.5 GPM........................................... 41

Table 3-35. 4-Stage Cold Cap Model Input for SB10-2 at 1.5 GPM.......................................... 42

Table 3-36. 4-Stage Cold Cap Model Input for SB10-3 at 1.5 GPM......................................... 42

Table 3-37. 4-Stage Cold Cap Model Input for SB10-5 at 1.5 GPM....................................... 43

Table 3-38. 4-Stage Cold Cap Model Input for SB10-7 at 1.5 GPM........................................ 43

Table 3-39. 4-Stage Cold Cap Model Input for SB10-8 at 1.5 GPM....................................... 44

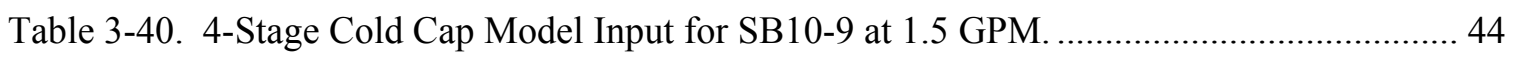

Table 3-41. Calculated Calcine Gas Compositions of Baseline Feeds at 1.5 GPM................... 45

Table 3-42. Calculated Glass Compositions of Baseline Feeds at 1.5 GPM.............................. 46

Table 3-43. Calculated Peak Flammability of Baseline SB10 Off-Gas @ OGCT during 9X/5X

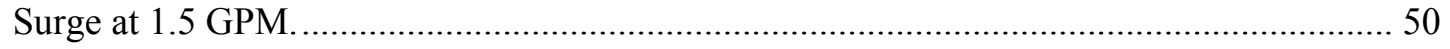

Table 3-44. Calculated Calcine Gas Compositions for Max-Coal Feeds at 1.5 GPM. ............... 51

Table 3-45. Calculated Glass Compositions of Max-Coal Feeds at 1.5 GPM............................ 52

Table 3-46. Maximum Coal-carbon Limits for SB10 Feeds at 60\% of LFL. ............................. 54

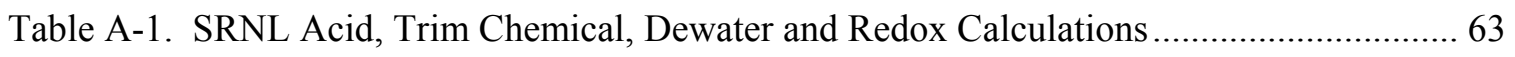

Table B-1. Analytical Results for SRAT Product and SME Product Filtered Slurries ................ 77

Table B-2. Analytical Results for Composite Dewater Samples................................................. 82

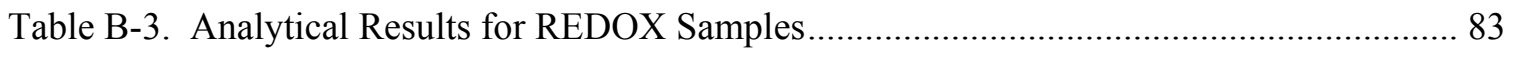

Table B-4. Analytical Results for $\mathrm{NaOH}$ Quenched Samples ................................................. 85

Table D-1. Composition of SB10-1 Baseline Melter Feed at 1.5 GPM ..................................... 94 
Table D-2. Composition of SB10-2 Baseline Melter Feed at 1.5 GPM ...................................... 95

Table D-3. Composition of SB10-3 Baseline Melter Feed at 1.5 GPM ....................................... 96

Table D-4. Composition of SB10-5 Baseline Melter Feed at 1.5 GPM ....................................... 97

Table D-5. Composition of SB10-7 Baseline Melter Feed at 1.5 GPM ...................................... 98

Table D-6. Composition of SB10-8 Baseline Melter Feed at 1.5 GPM ...................................... 99

Table D-7. Composition of SB10-9 Baseline Melter Feed at 1.5 GPM ................................... 100 


\section{LIST OF FIGURES}

Figure 3-1. 2009 PDT Sample Particle Size Distribution Results............................................... 7

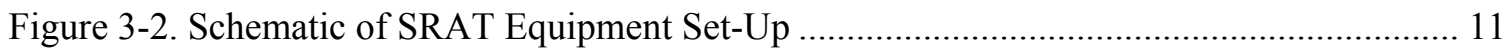

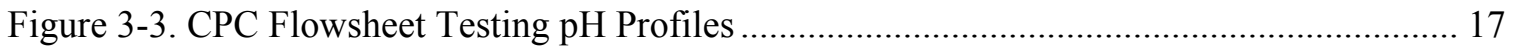

Figure 3-4. Typical SRAT Offgas Profile 100\% Acid Stoichiometry, no coal ............................ 23

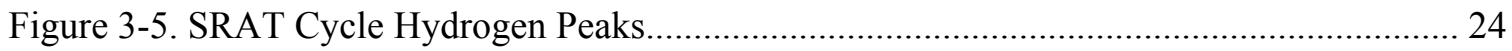

Figure 3-6. Carbon Dioxide and Nitrous Oxide Concentration in Runs SB10-2 and SB10-8 SRAT

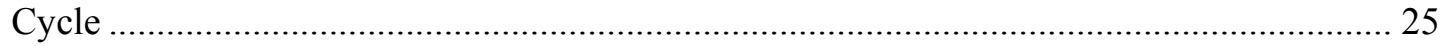

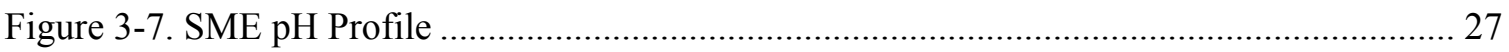

Figure 3-8. Typical SME Offgas Profile 100\% Acid Stoichiometry............................................ 34

Figure 3-9. Calculated, Predicted, and Measured Redox vs. Net Reducing Potential of Baseline

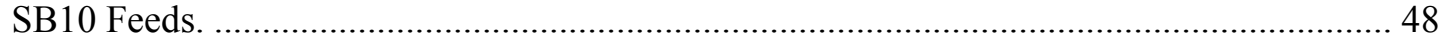

Figure 3-10. Results of 9X/5X Off-Gas Surge Simulation with Baseline SB10-1 Feed............. 49

Figure 3-11. Calculated Redox vs. Net Reducing Potential of Max-Coal SB10 Feeds. .............. 53

Figure 3-12. Results of 9X/5X Off-Gas Surge Simulation with SB10-1 Max-Coal Feed.......... 55

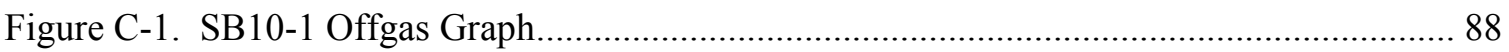

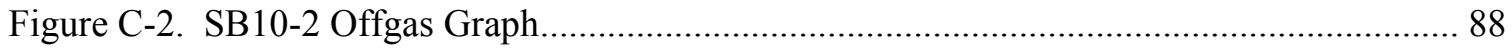

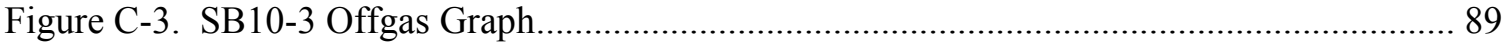

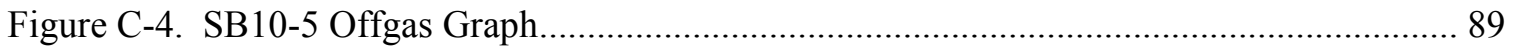

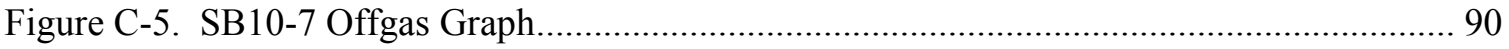

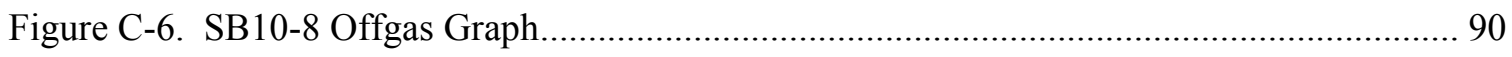

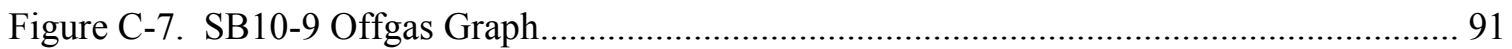




\section{LIST OF ABBREVIATIONS}

\begin{tabular}{|c|c|}
\hline ACTL & Aiken County Technical Laboratory \\
\hline $\mathrm{AD}$ & Analytical Development \\
\hline $\mathrm{CPC}$ & Chemical Processing Cell \\
\hline CSTR & Continuous Stirred Tank Reactor \\
\hline DOE-SR & Department of Energy - Savannah River \\
\hline DWPF & Defense Waste Processing Facility \\
\hline DCS & Distributed Control System \\
\hline FBSR & Fluidized Bed Steam Reformer \\
\hline FAVC & Formic Acid Vent Condenser \\
\hline ICP-AES & Inductively Couple Plasma - Atomic Emission Spectroscopy \\
\hline LFL & Lower Flammability Limit \\
\hline MCU & Modular Caustic Side Solvent Extraction Unit \\
\hline MOG & Melter Off-Gas \\
\hline MWWT & Mercury Water Wash Tank \\
\hline OGCT & Offgas Condensate Tank \\
\hline PSAL & Process Support Analytical Laboratory \\
\hline PTDT & Product Dissolution Tank \\
\hline REDOX & Reduction/Oxidation Potential (Ratio of $\mathrm{Fe}^{+2} / \Sigma \mathrm{Fe}$ ) \\
\hline SB & Sludge Batch \\
\hline SME & Slurry Mix Evaporator \\
\hline SMECT & Slurry Mix Evaporator Condensate Tank \\
\hline SRAT & Sludge Receipt and Adjustment Tank \\
\hline SRNL & Savannah River National Laboratory \\
\hline SRNS & Savannah River Nuclear Solutions \\
\hline SRR & Savannah River Remediation, LLC \\
\hline SRS & Savannah River Site \\
\hline SWPF & Salt Waste Processing Facility \\
\hline TPE & Tank 48 Project Engineering \\
\hline TSR & Technical Safety Requirement \\
\hline TIC & Total Inorganic Carbon \\
\hline TOC & Total Organic Carbon \\
\hline ТPB & Tetraphenylborate \\
\hline TT\&QAP & Task Technical and Quality Assurance Plan \\
\hline TTR & Technical Task Request \\
\hline
\end{tabular}


UDS

Undissolved Solids

WAC

Waste Acceptance Criteria 


\subsection{Introduction}

Currently Tank 48 has approximately 250,000 gallons of legacy waste containing organic potassium and cesium (K and $\mathrm{Cs}$ ) tetraphenyl borate (TPB) solids from the In-Tank Precipitation (ITP) project. The waste is incompatible with other Tank Farm treatment operations. The tank has been isolated from the Tank Farm service since 1998. In order to make space in the Savannah River Site (SRS) Tank Farm, the Tank 48 waste must be processed to eliminate its organic content for downstream processing, including Tank Farm and Defense Waste Processing Facility (DWPF) processes. On June 10, 2009, the Department of Energy-Savannah River (DOE-SR) concurred with Savannah River Remediation (SRR) Business Decision Recommendation to select the THOR ${ }^{\circledR}$ sodium carbonate based Fluidized Bed Steam Reforming (FBSR) technology to treat the Tank 48 waste. ${ }^{1}$ The FBSR processing of the Tank 48 content is expected to be completed over a two-year period from 2014 to 2016.

The FBSR process will treat the Tank 48 organic laden waste and generate organic free sodium carbonate based solid. The solids product will be slurried with water and sent to the Tank Farm for further processing. In the Tank Farm, the FBSR product slurry will be combined with sludge, washed as part of the sludge preparation process, and fed to DWPF. The FBSR product slurry will be blended with other sludge tanks to produce Sludge Batches 10-13 (SB10-SB13). Current projections of SB10-SB13 ${ }^{2}$ combined with expected composition of the FBSR product ${ }^{3}$ will be used to predict the resulting sludge composition for SB10-SB13.

DWPF will process the washed sludge concurrently with two products from salt waste, the cesium rich strip effluent stream and the actinide rich actinide removal product from the Salt Waste Processing Facility (SWPF). Both of these streams contain organic species that must be accounted for in the requested analysis. Until the SWPF begins processing, the products from the Actinide Removal Process (ARP) and the Modular Caustic-Side Solvent Extraction Unit (MCU) will be used. These streams will be defined as salt processing streams in the rest of the report.

DWPF targets the production of a melter feed that has a balanced REDOX (defined as 0.2 $\mathrm{Fe}^{+2} / \Sigma \mathrm{Fe}$ ). An acceptable REDOX range is $0.09-0.30$. It accomplishes this by using a blend of formic acid and nitric acid using a REDOX algorithm ${ }^{4}$ shown in Eq. (1) below. If the melter feed is too reducing (REDOX $>0.3$ ), metals such as copper, nickel and the noble metals can become reduced, accumulate in the bottom of the melter, and short out the electrodes, shortening the life of the melter. If the melter feed is too oxidizing (REDOX $<0.09$ ), the glass will release oxygen, causing melter foaming, pressure upsets, and slowing melt rate.

REDOX $=0.2358+0.1999 *\left(\left(2 * \mathrm{C}_{\text {formate }}+4 * \mathrm{C}_{\text {oxalate }}+4 * \mathrm{C}_{\text {Carbon }}-5 *\left(\mathrm{C}_{\text {Nitrate }}+\mathrm{C}_{\text {Nitrite }}\right)-5 * \mathrm{C}_{\mathrm{Mn}}\right)\right) *(45 / \mathrm{TS})$

Where $\mathrm{C}=$ species concentration, $\mathrm{g}$-mole $/ \mathrm{kg}$ melter feed, $\mathrm{TS}=$ total solids in melter feed in $\mathrm{wt} \%$, and $\mathrm{REDOX}$ is a molar ratio of $\mathrm{Fe}+2 / \Sigma \mathrm{Fe}$

Tank 48 contains a high organic concentration, due mainly to the potassium tetraphenylborate present. Approximately 40,000 lb of tetraphenylborate carbon is currently present in Tank 48 . Processing of the waste in the FBSR will produce approximately $80,000 \mathrm{lb}$ of carbon in the form of carbonate and another $120,000 \mathrm{lbs}$ of carbon in the form of residual coal-carbon ${ }^{13}$. Neither the carbon from coal or carbonate will wind up in the final glass waste form but may impact 
processing in DWPF and could lead to pluggage during CPC sampling and transferring due to the large particle size $\left(10 \%\right.$ greater than $\left.177 \mu \mathrm{m}^{1}\right)$ of the FBSR product.

The FBSR process uses coal-carbon as a reaction additive for promoting a reducing environment in the reformer as well as for maintaining the process in an auto-thermal mode. Some levels of coal-carbon (@100\% carbon) will be present in the FBSR product slurry to the Tank Farm / DWPF processing. The purpose of this study is to estimate a coal-carbon limit in the FBSR product for DWPF sludge receipt to ensure the sludge can be safely processed without impacting the DWPF safety basis. The primary products of this study are the results of the off-gas flammability assessment for the DWPF melter and the Chemical Processing Cell (CPC) demonstrations with simulant, which will provide an estimate of the total organic carbon (TOC) limit along with the associated coal-carbon limit. It should be noted that the TOC varies from sludge batch to sludge batch due to composition changes in oxalate, coal-carbon, and other carbon sources but the main contributor to the TOC in the melter feed is the formate salts originating from the addition of formic acid.

Tank 48 Projects Engineering (TPE) of Savannah River Remediation (SRR) has requested this demonstration via Technical Task Request (TTR) X-TTR-H-2009-00006. ${ }^{5}$ The scope of the study is being controlled with the Task Technical and Quality Assurance Plan (TT\&QAP). ${ }^{6}$

This work is Technical Baseline Research and Development (R\&D) for an onsite customer (Tank 48 and DWPF).

\subsection{Initial Paper Study}

A paper study ${ }^{7}$ was completed to estimate the impact of the FBSR coal-carbon on DWPF CPC processing. The paper study included a prediction of SME product composition and REDOX, a melter offgas flammability model, a cold cap model, and an off-gas dynamics model. However, a number of estimates were made for anion destruction that needed to be validated by experiments. The results of the paper study are not reproduced in this revision for brevity and because the experimental results are closer to expected processing parameters.

Four waste streams will be added to the DWPF CPC once the FBSR begins processing the Tank 48 contents. The four streams and their expected volumes are summarized in Table 2-1. As part of this study, it was assumed that DWPF will be producing 325 canisters per year $(1.25$ million $\mathrm{lb} / \mathrm{yr}$ of glass) using the current DWPF chemical processing flowsheet and that the FBSR and salt streams will be processing at design capacity. In addition, it is assumed that no other processing facilities are providing waste to DWPF.

\footnotetext{
${ }^{1}$ Maximum frit particle size is 80 mesh or $177 \mu \mathrm{m}$
} 
Table 2-1. DWPF Processing Streams during FBSR Processing

\begin{tabular}{|c|c|c||}
\hline Waste Stream & $\begin{array}{c}\text { Annual Production } \\
\text { Rate, gal/yr }\end{array}$ & Primary carbon source \\
\hline Sludge & $\begin{array}{c}\text { Depends on sludge } \\
\text { batch }\end{array}$ & Carbonate, oxalate \\
\hline $\begin{array}{c}\text { FBSR Product Dissolution } \\
\text { Tank (PDT) }\end{array}$ & 160,000 & Unreacted Coal, carbonate \\
\hline Strip Effluent & 564,000 & $\begin{array}{c}\text { Solvent (Isopar, modifier, } \\
\text { extractant, and suppressor) }\end{array}$ \\
\hline Actinide Removal Stream & 121,000 & Oxalate, carbonate \\
\hline
\end{tabular}

Note that the assumption of 325 canisters per year in DWPF is lower than the ultimate SRR plan of 400 canisters per year. At 325 canisters per year, $19 \%$ less sludge will be processed compared to 400 canisters per year. Since the FBSR processing rate is assumed constant, production at the higher throughput will effectively dilute the coal-carbon, leading to lower coal-carbon concentrations being fed into DWPF. However, if the 325 canister per year production rate can not be achieved, the coal-carbon concentration will be higher than estimated in this study. Also it should be noted that the sludge production rate (noted in the table above as "depends on sludge batch") was calculated by difference, setting the SWPF and FBSR streams at their flowsheet targets, and calculating the volume of sludge that can be processed to achieve the 325 canister per year production rate.

The Hazen testing FBSR product ${ }^{3}$ was between 9.3 and $17.1 \mathrm{wt} \%$ coal-carbon-carbon so $15 \%$ coal-carbon was used as a basis in this study. Coal is added in the FBSR product and some of this coal is unreacted and exits with the FBSR product. The coal-carbon in the 2008 Hazen product $^{3}$ was much higher than was measured in earlier processing. As a result, this study was initiated to develop waste acceptance criteria (WAC) to prevent a flammable mixture from forming in the DWPF melter offgas system.

Not all of the carbon fed to DWPF is fed to the melter. For example, formic acid, another carbon source, and nitric acid are added to the CPC to neutralize the waste. Neutralization of the waste destroys all of the carbonate and a portion of the oxalate. The addition of formic acid adds a large quantity of organic that will be fed to the melter. Also, volatile organics such as Isopar are steam stripped during processing so they do not reach the melter. However, the coal-carbon is inert during CPC processing and will be fed to the melter. The melter will oxidize all the remaining carbon to $\mathrm{CO}$ and $\mathrm{CO}_{2}$ which may lead to a flammable offgas mixture if the carbon concentration in the melter feed is too high. The coal also adds other impurities that impact DWPF processing including hydrogen (impacts melter offgas flammability), sulfur, and coal ash. The coal composition of two coal sources used in FBSR testing is summarized in Table 2-2. ${ }^{3}$ The ash content of the coal, similar to the solids present in sludge, is summarized in Table 2-3. 
Table 2-2. Coal Composition, wt \%

\begin{tabular}{|l|l|l|}
\hline Component & Erwin & Bestac \\
\hline Moisture & 7.35 & 8.37 \\
\hline Ash & 7.77 & 9.12 \\
\hline $\mathrm{Al}$ & 0.81 & 1.26 \\
\hline $\mathrm{Ca}$ & 0.17 & 0.14 \\
\hline $\mathrm{Fe}$ & 0.15 & 0.44 \\
\hline $\mathrm{K}$ & 0.01 & 0.03 \\
\hline $\mathrm{Mg}$ & 0.06 & 0.01 \\
\hline $\mathrm{Na}$ & 0.10 & 0.03 \\
\hline $\mathrm{P}$ & 0.01 & 0.05 \\
\hline $\mathrm{Si}$ & 2.14 & 2.59 \\
\hline Ti & 0.04 & 0.04 \\
\hline Other & 0.31 & 0.01 \\
\hline Carbon & 80.45 & 78.59 \\
\hline Hydrogen & 1.58 & 2.09 \\
\hline Oxygen & 1.69 & 0.39 \\
\hline Nitrogen & 0.84 & 0.72 \\
\hline Sulfur & 0.30 & 0.72 \\
\hline Total & 103.8 & 104.6 \\
\hline
\end{tabular}

Table 2-3. Coal Ash Composition, wt \%

\begin{tabular}{|l|c|c|}
\hline \multirow{2}{*}{ Component } & \multicolumn{2}{|c|}{$\begin{array}{c}\text { Normalized SRNL Ash Analysis } \\
\text { 2006 Erwin } \\
\text { Ash@525 }\end{array}$} \\
\hline $\mathrm{Al}_{2} \mathrm{O}_{3}$ & $\begin{array}{c}\mathbf{2 0 0 8} \text { Bestac } \\
\text { Ash@525 }\end{array}$ \\
\hline $\mathrm{CaO}$ & $2.99 \%$ & $\mathbf{C} \%$ \\
\hline $\mathrm{Fe}_{2} \mathrm{O}_{3}$ & $2.70 \%$ & $2.21 \%$ \\
\hline $\mathrm{K}_{2} \mathrm{O}$ & $0.13 \%$ & $6.91 \%$ \\
\hline $\mathrm{MgO}$ & $1.24 \%$ & $0.34 \%$ \\
\hline $\mathrm{Na}_{2} \mathrm{O}$ & $1.69 \%$ & $0.18 \%$ \\
\hline $\mathrm{P}_{2} \mathrm{O}_{5}$ & $0.39 \%$ & $0.49 \%$ \\
\hline $\mathrm{SO}_{4}$ & $7.50 \%$ & $1.15 \%$ \\
\hline $\mathrm{SiO}_{2}$ & $58.91 \%$ & $1.02 \%$ \\
\hline $\mathrm{TiO}_{2}$ & $0.76 \%$ & $60.77 \%$ \\
\hline Other & $4.05 \%$ & $0.73 \%$ \\
\hline Total & $100.00 \%$ & $0.10 \%$ \\
\hline \multicolumn{2}{|c|}{} \\
\hline
\end{tabular}

\subsection{Results and Discussion}

Seven SRAT/SME runs (SB10-1,2,3,5,7,8 and 9) were completed during this study using acid stoichiometries of $100 \%$ and $150 \%$ with a blend of SB10-A (no added FBSR) and SB10-B (added FBSR) simulant. The SB10-B simulant was prepared by producing an unwashed SB10 simulant, adding Hazen FBSR PDT slurry (high coal-carbon and sodium carbonate content), and washing to $\sim 1 \mathrm{M}$ sodium with inhibited water. These runs were completed and samples analyzed using the practices and procedures typical for CPC simulations at the Aiken County Technology Laboratory (ACTL), as described below. 


\subsection{Simulant Preparation}

Two simulant batches were prepared, one simulating the best estimate of the SB10 composition without added FBSR PDT (SB10-A coal-free sludge simulant) and the other simulating the expected sludge composition with FBSR PDT added to the sludge preparation tank (SB10-B coal added sludge simulant). The SB10-A sludge simulant used targets were specified by the Tank 48 Project Team. ${ }^{8}$

\subsubsection{Analysis of 2009 Hazen PDT Sample}

A sample was pulled from one of the Hazen PDT sample drums for combining with the sludge simulant to produce a sludge simulant for this testing. Two critical analyses were performed of the PDT sample, namely a carbon estimate and a particle size measurement. The composition of the FBSR PDT product is shown in Table 3-1. A particle size distribution graph is shown in Figure 3-1.

Table 3-1 2009 Hazen PDT Sample Results

\begin{tabular}{||l||c|}
\hline \multicolumn{1}{|c|}{ Component } & FBSR PDT \\
\hline Total Solids, wt \% & 18.73 \\
\hline Dissolved Solids, wt \% & 12.75 \\
\hline Undissolved Solids, wt \% & 5.98 \\
\hline Carbon Undissolved Solids, wt TS\% & 21.95 \\
\hline Non-carbon Undissolved Solids, wt \% TS & 10.03 \\
\hline Dissolved Solids, wt \% TS & 68.02 \\
\hline Carbon Undissolved Solids $>80$ mesh, wt \% TS & 0.91 \\
\hline Carbon Undissolved Solids $80-100$ mesh, wt \% TS & 0.97 \\
\hline Carbon Undissolved Solids 100-120 mesh, wt \% TS & 7.40 \\
\hline Carbon Undissolved Solids $<120$ mesh, wt \% TS & 12.68 \\
\hline Non-carbon Undissolved Solids $>80$ mesh, wt \% TS & 0.02 \\
\hline Non-carbon Undissolved Solids $80-100$ mesh, wt \% TS & 0.12 \\
\hline Non-carbon Undissolved Solids $100-120$ mesh, wt \% TS & 1.44 \\
\hline Non-carbon Undissolved Solids $<120$ mesh, wt \% TS & 8.44 \\
\hline
\end{tabular}




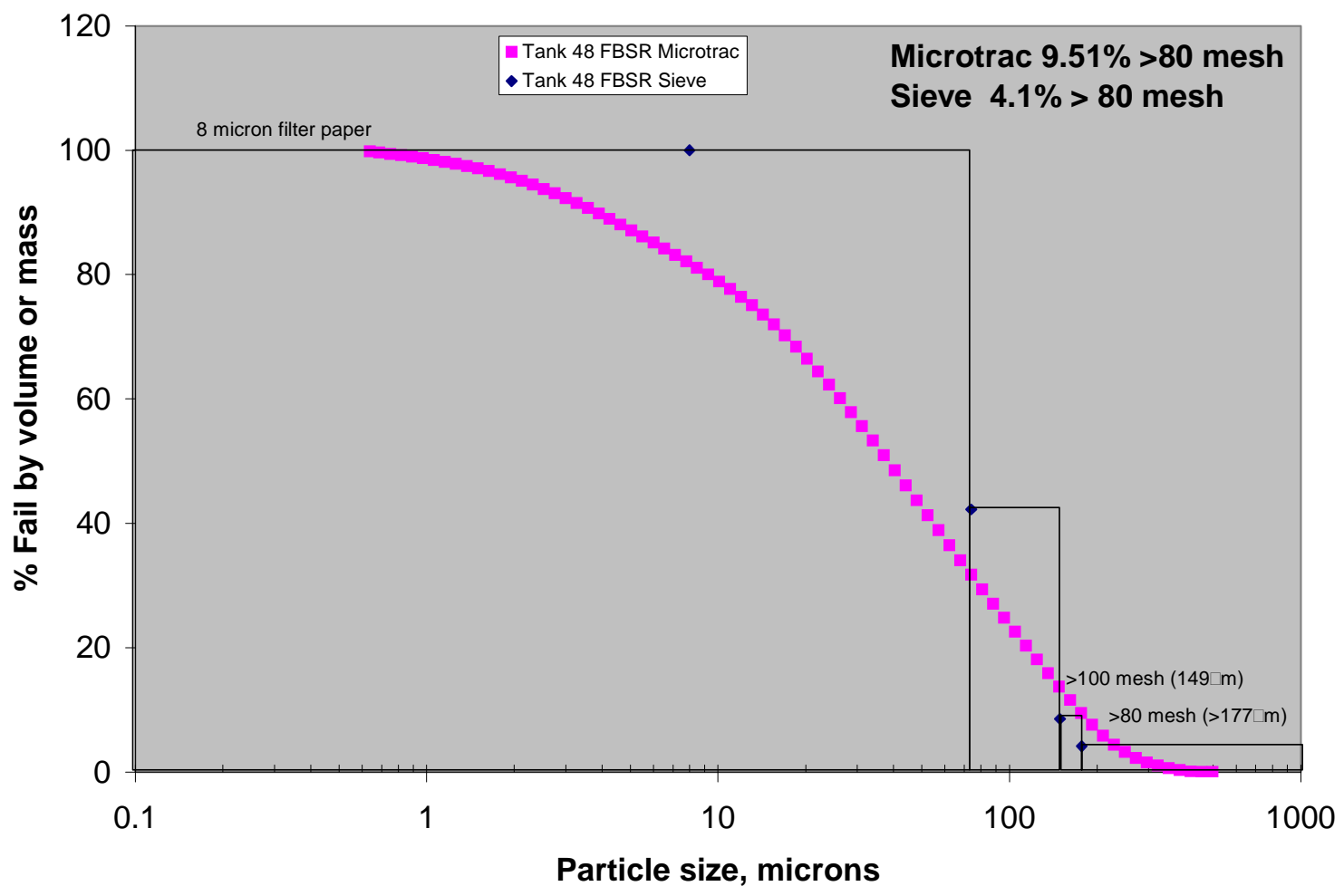

Figure 3-1. 2009 PDT Sample Particle Size Distribution Results

The concentration of the residual coal-carbon in the FBSR PDT is of critical importance to this study. The analysis of the coal-carbon in Tank 48 PDT products have led to variable results by different laboratories and different methods. The method used for estimating the coal-carbon in the FBSR PDT was developed by SRNL for coal-carbon analysis of FBSR PDT product ${ }^{9}$. The SRNL analysis avoids the complications of having hydrous carbonates present during the analysis and accounts for the non-carbon undissolved solids (UDS). This procedure has several steps which include (1) drying the product at $110^{\circ} \mathrm{C}$ to achieve a constant weight, (2) dissolution of solids at a ratio of 1 gram to $100 \mathrm{~mL}$ of water (considered infinite dilution), (3) filtration of the dissolved product to purge the sample of the soluble carbonates (anhydrous and hydrous), (4) redrying to a constant weight at $110^{\circ} \mathrm{C}$, and (5) roasting the UDS at $525^{\circ} \mathrm{C}$ for two days to determine the $\mathrm{wt} \%$ volatile carbon UDS from the wt\% noncarbon UDS. The concentration of coal-carbon in the SB10-B slurry and all blends of the SB10-A and SB10-B slurries were calculated by mass balance knowing the mass of sludge and FBSR PDT solids in the SB10-B slurry.

\subsubsection{Simulant Preparation}

The preparation of a simulant for Sludge Batch 10-A involved six steps: precipitation of manganese (IV) oxide, caustic precipitation of a metal nitrate solution, addition of sodium carbonate, washing of the precipitated solids, addition of minor insoluble species, and addition of soluble species. The precipitation of metal nitrates to form insoluble oxides and hydroxides was conducted in a Continuous Stirred Tank Reactor (CSTR) and involved generation of a metal nitrate solution followed by precipitation of the metal nitrates through the addition of sodium hydroxide. Following the addition of sodium carbonate, the material was washed then 
soluble/insoluble species were added. Procedure L29 ITS-00124 ${ }^{10}$, "SRS HLW Sludge Simulant Preparation" was utilized to perform the tests.

The preparation of a simulant for Sludge Batch 10-B involved eight steps. This is different than typical sludge preparation to mimic the washing of the combined unwashed sludge and FBSR PDT material that will be completed in the sludge preparation tank. The first four steps of the preparation for both sludges were identical, so the sludges were prepared as a single batch and split once step 4 met the nitrate target for SB10-B prewashing. Once SB10-B slurry was separated from the SB10-A batch, the soluble salts were added to the SB10-B slurry to produce a $5 \mathrm{M}$ supernate. The Tank 48 Hazen produced FBSR PDT solution was added to the sludge mixture which was washed with inhibited water down to approximately $1 \mathrm{M} \mathrm{Na}$, decanted, and the soluble/insoluble species were added.

The simulants were prepared using facilities at both ACTL and in 735-11A. The $\mathrm{MnO}_{2}$ precipitation, the precipitation in the CSTR and the precipitation of the insoluble carbonate species were each completed in one day. The washing and concentration of the precipitate took approximately three weeks, while the final insoluble and soluble species were added in one day. The final slurry was sampled and analyzed at ACTL, the Process Science Analytical Laboratory (PSAL), and by Analytical Development (AD). The results of these analyses are summarized in Table 3-2. The SB10 simulants were very thin rheologically. The mercury and noble metals were not added to the simulant. Noble metals, mercury, and rinse water were added to the sludge simulant prior to performing the SRAT cycle. The noble metal concentrations were based on $100 \%$ of the SB6 estimated noble metals. Since the SB10 mercury content is not known, the mercury concentration was chosen so that the mercury could be steam stripped down to $0.6 \mathrm{wt} \%$ assuming a mercury strip factor of 750 pounds steam per pound mercury in 12 hours. The concentrations of each trim chemical added are shown in Table 3-3. Note that SB10-B has lower noble metal and mercury concentration since the FBSR product contains negligible noble metals and mercury.

In preparation for the experiments, the SB10-A and SB10-B sludge simulants were blended to provide four levels of carbon (from 0 to $9.545 \mathrm{wt} \% \mathrm{C}$ ) as calculated from the PDT analysis. The projected composition of the four sludge blends is summarized in Table 3-4. 
Table 3-2 Simulant Composition for Flowsheet Testing

\begin{tabular}{|c|c|c|c|c|c|}
\hline Analyses & SB10-A & SB10-B & Analyses & SB10-A & SB10-B \\
\hline Elemental & \multicolumn{2}{|c|}{ Wt\% calcined solids } & Solids Data & \multicolumn{2}{|c|}{ Wt \% } \\
\hline $\mathrm{Al}$ & 6.66 & 4.42 & Total Solids & 17.84 & 15.45 \\
\hline $\mathrm{Ba}$ & 0.222 & 0.252 & Insoluble Solids & 14.37 & 11.65 \\
\hline $\mathrm{Ca}$ & 2.50 & 2.92 & Calcined Solids & 11.16 & 11.58 \\
\hline $\mathrm{Ce}$ & 0.742 & 0.802 & Soluble Solids & 3.47 & 3.80 \\
\hline $\mathrm{Cr}$ & 0.138 & 0.150 & Anions & \multicolumn{2}{|c|}{ mg/kg slurry } \\
\hline $\mathrm{Cu}$ & 0.056 & 0.059 & Nitrite & 9,430 & 6,680 \\
\hline $\mathrm{Fe}$ & 27.9 & 30.9 & Nitrate & 5,690 & 4,890 \\
\hline $\mathrm{K}$ & 0.202 & 0.253 & Formate & 0 & 0 \\
\hline $\mathrm{La}$ & 0.250 & 0.278 & Sulfate & 312 & 323 \\
\hline $\mathrm{Mg}$ & 0.330 & 0.367 & Chloride & 0 & 352 \\
\hline $\mathrm{Mn}$ & 5.35 & 5.83 & Phosphate & 0 & 0 \\
\hline $\mathrm{Na}$ & 14.7 & 13.6 & Oxalate & 0 & 140 \\
\hline $\mathrm{Ni}$ & 0.736 & 0.830 & Total Carbonate & 6,960 & 11,500 \\
\hline $\mathrm{P}$ & $<0.100$ & $<0.100$ & Other Results & & \\
\hline $\mathrm{Pb}$ & 0.186 & 0.190 & Base Equivalents (molar) & 0.909 & 0.664 \\
\hline $\mathrm{S}$ & 0.066 & 0.071 & Slurry Density $(\mathrm{g} / \mathrm{ml})$ & 1.153 & 1.125 \\
\hline $\mathrm{Si}$ & 2.24 & 3.51 & Supernate Density $(\mathrm{g} / \mathrm{ml})$ & 1.058 & 1.036 \\
\hline $\mathrm{Ti}$ & $<0.010$ & 0.141 & Slurry TIC, mg/kg & 1,347 & 2,219 \\
\hline $\mathrm{Zn}$ & 0.067 & 0.049 & Soluble TIC, $\mathrm{mg} / \mathrm{kg}$ & 1,151 & 1,719 \\
\hline \multirow[t]{2}{*}{$\mathrm{Zr}$} & 0.450 & 0.483 & $\mathrm{pH}$ & 13.4 & 13.3 \\
\hline & & & $\begin{array}{l}\text { Calculated Coal-carbon, wt \% } \\
\text { TS }\end{array}$ & 0 & 9.545 \\
\hline
\end{tabular}

Table 3-3 Trim Chemical Additions, wt \% on Total Solids Basis

\begin{tabular}{|l|c|c|}
\hline \multicolumn{1}{|c|}{ TRIM CHEMICAL } & SB10-A & SB10-B \\
\hline Trimmed Sludge Target Ag metal content & 0.0142 & 0.0108 \\
\hline Trimmed Sludge Target wt $\%$ Hg dry basis & 1.6188 & 1.2272 \\
\hline Trimmed Sludge Target Pd metal content & 0.0066 & 0.0050 \\
\hline Trimmed Sludge Target Rh metal content & 0.0233 & 0.0177 \\
\hline Trimmed Sludge Target Ru metal content & 0.1121 & 0.0850 \\
\hline
\end{tabular}


Table 3-4 Calculated Blended Sludge Composition

\begin{tabular}{|c|c|c|c|c|}
\hline Analyses & SB10-1,2 & SB10-3,9 & SB10-5 & SB10-7,8 \\
\hline Composition & $0 \% \mathrm{~A}, 100 \% \mathrm{~B}$ & $32.0 \% \mathrm{~A}, 68.0 \% \mathrm{~B}$ & $66.3 \% \mathrm{~A}, 33.7 \% \mathrm{~B}$ & $100 \% \mathrm{~A}, 0 \% \mathrm{~B}$ \\
\hline Solids Data & \multicolumn{4}{|c|}{ Wt \% } \\
\hline Total Solids & $15.45 \%$ & $16.21 \%$ & $17.04 \%$ & $17.84 \%$ \\
\hline Insoluble Solids & $11.58 \%$ & $11.44 \%$ & $11.30 \%$ & $11.16 \%$ \\
\hline Calcined Solids & $3.87 \%$ & $4.77 \%$ & $5.74 \%$ & $6.69 \%$ \\
\hline Soluble Solids & $11.65 \%$ & $12.52 \%$ & $13.45 \%$ & $14.37 \%$ \\
\hline Anions & \multicolumn{4}{|c|}{ mg/kg slurry } \\
\hline Chloride & 351.5 & 238.9 & 118.4 & $<100$ \\
\hline Nitrite & 6680 & 7562 & 8507 & 9435 \\
\hline Nitrate & 4895 & 5150 & 5422 & 5690 \\
\hline Formate & 0 & 0 & 0 & 0 \\
\hline Sulfate & 323 & 319 & 316 & 312 \\
\hline Oxalate & 137 & 95 & 47 & $<100$ \\
\hline Phosphate & $<100$ & 0 & 0 & $<100$ \\
\hline Total Carbonate & 2219 & 1940 & 1641 & 1347 \\
\hline \multicolumn{5}{|l|}{ Other Results } \\
\hline Base Equivalents (molar) & 0.590 & 0.741 & 0.825 & 0.789 \\
\hline Slurry Density $(\mathrm{g} / \mathrm{ml})$ & 1.125 & 1.134 & 1.144 & 1.153 \\
\hline $\mathrm{pH}$ & 13.3 & 13.1 & 12.8 & 13.4 \\
\hline $\begin{array}{l}\text { Soluble Total Inorganic C, } \\
\mathrm{mg} / \mathrm{kg} \text { slurry }\end{array}$ & 1719 & 1539 & 1345 & 1151 \\
\hline $\begin{array}{l}\text { Calculated Coal-Carbon, } \\
\mathrm{Wt} \%\end{array}$ & 9.59 & 6.21 & 2.93 & 0.00 \\
\hline
\end{tabular}

\subsection{Experimental Apparatus}

The testing was performed at the ACTL using the four-liter kettle setup. The SRAT rigs were assembled following the guidelines of SRNL-PSE-2006-00074 ${ }^{11}$. The intent of the equipment is to functionally replicate the DWPF processing vessels. The 4-liter glass kettle is used to replicate both the SRAT and SME, and it is connected to the SRAT Condenser, the Mercury Water Wash Tank (MWWT), and the Formic Acid Vent Condenser (FAVC). The Slurry Mix Evaporator Condensate Tank (SMECT) is represented by a sampling bottle that is used to remove condensate through the MWWT. For the purposes of this paper, the condensers and wash tank are referred to as the offgas components. A sketch of the experimental setup is given as Figure 3-2. 


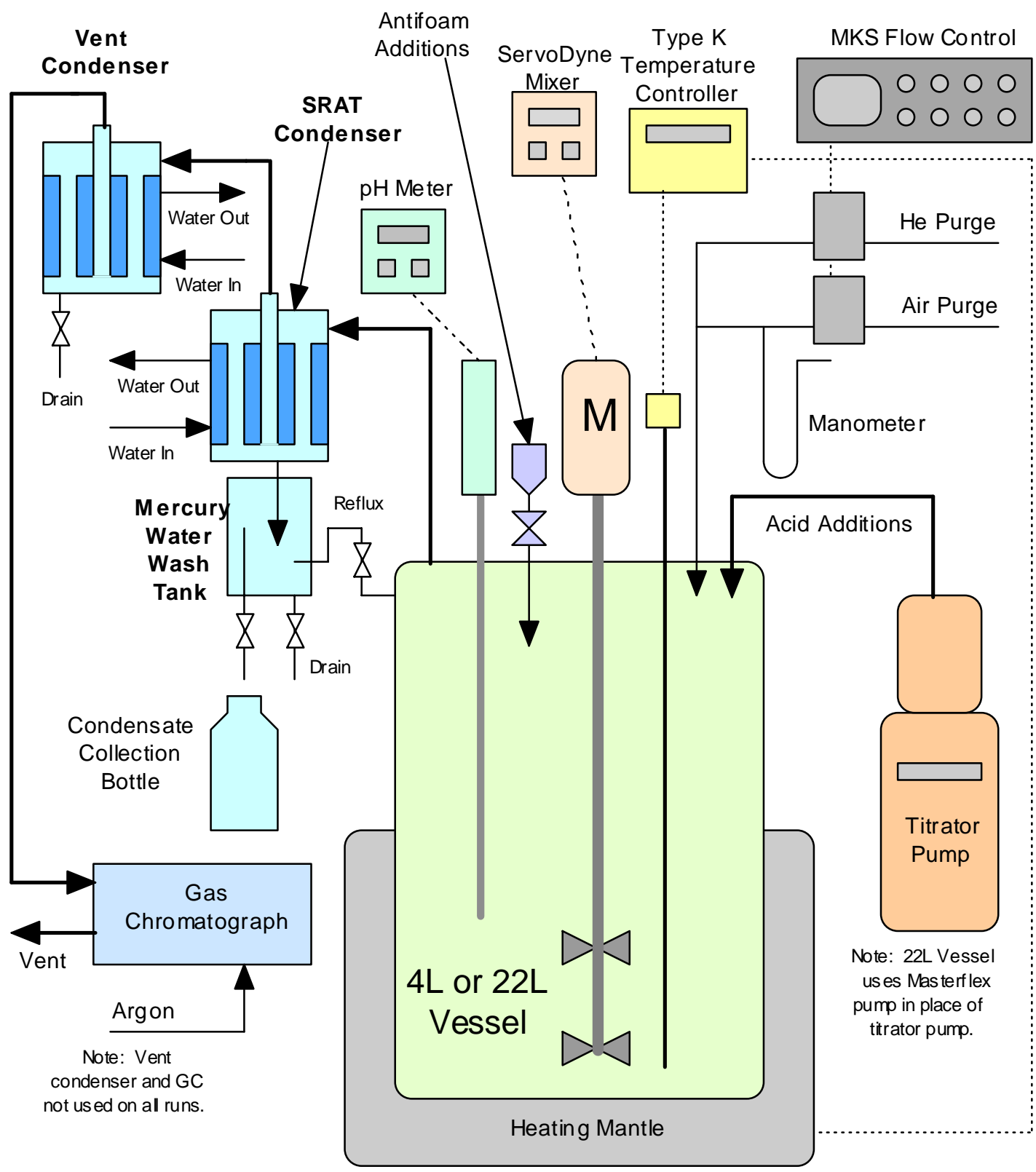

Figure 3-2. Schematic of SRAT Equipment Set-Up

The flowsheet runs were performed using the guidance of Procedure ITS-0094 (2 (Laboratory Scale Chemical Process Cell Simulations") of Manual L29. Offgas hydrogen, oxygen, nitrogen, nitrous oxide, and carbon dioxide concentrations were measured during the experiments using inline instrumentation. Helium was introduced at a concentration of $0.5 \%$ of the total air purge as an inert tracer gas so that total amounts of generated gas and peak generation rates could be calculated. During the runs, the kettle was monitored to observe reactions that were occurring to include foaming, air entrainment, rheology changes, loss of heat transfer capabilities, and offgas carryover. Observations were recorded on data sheets and pasted into a laboratory notebook. ${ }^{13}$ 
Concentrated nitric acid $(50-\mathrm{wt} \%)$ and formic acid $(90-\mathrm{wt} \%)$ were used to acidify the sludge and perform neutralization and reduction reactions during processing. The amounts of acid to add for each run were determined using the proposed Koopman DWPF acid addition equation. ${ }^{14}$ The split of the acid was determined using the REDOX equation currently being used in DWPF processing. ${ }^{15}$ The REDOX target $\left(\mathrm{Fe}^{2+} / \Sigma \mathrm{Fe}\right)$ was 0.2 . To account for the reactions and anion destructions that occur during processing, assumptions about nitrite destruction, nitrite to nitrate conversion, and formate destruction were made for each run.

To prevent foaming during SRAT processing, 200 ppm IIT 747 antifoam was added before acid addition, $100 \mathrm{ppm}$ was added after nitric acid addition was complete and $500 \mathrm{ppm}$ was added at the completion of formic acid addition. SRAT processing included 12-hours at boiling (dewater time plus reflux time). The SME processing did not include the addition of canister dewaters. The frit addition was split into two equal portions. The frit was added with water and formic acid at DWPF prototypical conditions. Concentration was performed after each frit addition and then heat was removed to allow for the next frit addition. A final concentration was performed at the end of the run to meet the 50 weight percent total solids target. The SRAT condenser was maintained at $25^{\circ} \mathrm{C}$ during the run, while the vent condenser was maintained at $4^{\circ} \mathrm{C}$.

\subsection{SRAT Cycle Results}

Seven SRAT/SME runs (SB10-1, 2, 3, 5, 7, 8, and 9) were completed during this study using acid stoichiometries of $100 \%$ and $150 \%$. A unique run number was assigned to each run. SB10-1 and SB10-2 were SRAT/SME Cycles with sludge SB10-B only. SB10-7 and SB10-8 were SRAT/SME Cycles with sludge SB10-A only. SB10-3, SB10-5 and SB10-9 were SRAT/SME Cycles with blends of sludge SB10-A and SB10-B as shown in Table 3-4. All runs targeted a predicted glass REDOX $\left(\mathrm{Fe}^{2+} / \Sigma \mathrm{Fe}\right)$ of 0.2 by adjusting the ratio of formic to nitric acid during the SRAT cycle and using the current REDOX equation. ${ }^{4}$ The runs targeted a waste loading of $38 \%$ instead of the $40 \%$ specified in the Task Plan.

Table 3-5 SRAT/SME Test Targets

\begin{tabular}{|c|c|c|c|c|}
\hline Run Number & Acid Stoichiometry & $\begin{array}{c}\text { REDOX } \\
\text { Target }\end{array}$ & $\begin{array}{c}\text { Sludge } \\
\text { Predicted Coal- } \\
\text { carbon, mg/kg }\end{array}$ & Waste Loading \\
\hline SB10-1 & $97 \%$ & 0.2 & 19,800 & $38 \%$ \\
\hline SB10-2 & $150 \%$ & 0.2 & 18,500 & $38 \%$ \\
\hline SB10-3 & $103 \%$ & 0.2 & 12,900 & $38 \%$ \\
\hline SB10-5 & $100 \%$ & 0.2 & 5,870 & $38 \%$ \\
\hline SB10-7 & $100 \%$ & 0.2 & 0 & $38 \%$ \\
\hline SB10-8 & $150 \%$ & 0.2 & 0 & $38 \%$ \\
\hline SB10-9 & $150 \%$ & 0.2 & 10,000 & $38 \%$ \\
\hline
\end{tabular}

The SRAT cycles were completed using conservative design basis inputs such as acid addition flowrates, air purges, and steam flowrates.

Two processing issues were noted in this series of tests. For SB10-A sludge (no coal) runs, the high acid stoichiometry (i.e., 150\%) led to high hydrogen generation and low recovery of mercury. For SB10-A sludge (no coal), the low acid stoichiometry (i.e., 100\%) SRAT product had approximately $13 \%$ of the nitrite still present after 12 hours of processing. 


\subsubsection{Acid Addition Calculation}

An acid calculation was completed prior to each experiment to estimate a number of scaled parameters necessary to complete each experiment at the conditions specified with the inputs such as kettle power (designed to simulate steam flow), acid addition flowrate, offgas purge, acid volume, etc. Results from the acid calculation and other run data are summarized in Appendix A.

\subsubsection{Calculation Inputs}

The SRAT cycle acid calculation utilizes the amount of nitrite, mercury, manganese, carbonate, and base equivalents to calculate the stoichiometric amount of acid to be added. Nitric acid and formic acid amounts are calculated ${ }^{16}$ based on the applied stoichiometric factor and the ratio needed to achieve the predicted glass REDOX target of $0.2 \mathrm{Fe}^{+2} / \Sigma \mathrm{Fe}$. The equation for prediction of glass REDOX utilizes estimates of the amount of formate, oxalate, nitrate, nitrite, manganese, and total solids in the SME product. The estimation of the final concentration for the anions requires assumptions to be made concerning how these species will react during the SRAT and SME cycles. Formate and oxalate are destroyed by reactions with oxidizing species and by catalytic reactions with noble metals. Nitrite is typically consumed during the SRAT cycle, but can react to form different species including nitrate, $\mathrm{NO}, \mathrm{NO}_{2}$ and $\mathrm{N}_{2} \mathrm{O}$.

Three different acid addition predictions were used. The Hsu equation, an equation with inputs for total base, slurry carbonate, nitrite, manganese and mercury, has been used for estimating the acid requirement in DWPF since startup. Two new acid equations ${ }^{14}$, which more accurately predict the acid requirement in DWPF, have been developed. The Koopman equation adds inputs for supernate (not slurry) carbonate, calcium and magnesium to better predict the acid requirement. The cation equation uses cations (manganese, sodium, potassium, mercury, cesium, strontium, calcium, nickel, and magnesium) to predict the acid demand with credits for anions (nitrite, nitrate, sulfate, chloride, formate and phosphate). Both of these new equations were developed for minimum acid (just enough acid to destroy nitrite with very little hydrogen generation) and nominal acid (enough acid to destroy nitrite, reduce mercury, and without making too much hydrogen). The minimum Koopman equation's prediction of acid requirement was used throughout the testing and the other results are summarized in Table 3-6. The acid calculation inputs and assumptions are shown in Table 3-7 for the SRAT cycle and Table 3-8 for the SME cycle. It should be noted that the anion conversion predictions were changed between the two sets of experiments (SB10-1, SB10-2, SB10-7 and SB10-8) and the second set of experiments (SB10-3, SB10-5, and SB10-9). Sample results from the first set of experiments were used to predict the anion conversions for the second set of experiments.

Table 3-6 Acid Calculation Results

\begin{tabular}{|l|c|c|c|c|c|c|c|}
\hline Equation & SB10-1 & SB10-2 & SB10-3 & SB10-5 & SB10-7 & SB10-8 & SB10-9 \\
\hline Hsu Equation, M & 3.87 & 3.87 & 3.87 & 3.87 & 3.87 & 3.87 & 3.65 \\
\hline Nominal Koopman, M & 4.51 & 4.51 & 4.51 & 4.51 & 4.51 & 4.51 & 4.38 \\
\hline Minimum Koopman, M & 3.80 & 3.80 & 3.80 & 3.80 & 3.80 & 3.80 & 3.73 \\
\hline Nominal Cation, M & 3.74 & 3.74 & 3.74 & 3.74 & 3.74 & 3.74 & 4.06 \\
\hline Minimum Cation, M & 3.16 & 3.16 & 3.16 & 3.16 & 3.16 & 3.16 & 3.53 \\
\hline
\end{tabular}


Table 3-7 SRAT Cycle Processing Parameters and Assumptions

\begin{tabular}{|c|c|c|c|c|c|c|c|c|}
\hline Description & Units & $\begin{array}{c}\text { SB10- } \\
1\end{array}$ & $\begin{array}{l}\text { SB10- } \\
2\end{array}$ & $\begin{array}{c}\text { SB10- } \\
3\end{array}$ & $\begin{array}{l}\text { SB10- } \\
5\end{array}$ & $\begin{array}{c}\text { SB10- } \\
7\end{array}$ & $\begin{array}{c}\text { SB10- } \\
8\end{array}$ & $\begin{array}{c}\text { SB10- } \\
9\end{array}$ \\
\hline Sludge SB10-A & & $\mathbf{0 \%}$ & $0 \%$ & $32.0 \%$ & $66.3 \%$ & $100 \%$ & $100 \%$ & $32.0 \%$ \\
\hline Sludge SB10-B & & $100 \%$ & $100 \%$ & $68.0 \%$ & $33.7 \%$ & $\mathbf{0 \%}$ & $\mathbf{0 \%}$ & $68.0 \%$ \\
\hline $\begin{array}{l}\text { Conversion of Nitrite to Nitrate } \\
\text { in SRAT Cycle }\end{array}$ & $\begin{array}{c}\mathrm{gmol} \mathrm{NO}_{3} / 100 \\
\mathrm{gmol} \mathrm{NO}_{2} \\
\end{array}$ & 22.0 & 25.0 & -6.0 & -5.9 & 22.0 & 28.0 & -27.3 \\
\hline $\begin{array}{l}\text { Destruction of Nitrite in SRAT } \\
\text { and SME cycle }\end{array}$ & $\begin{array}{c}\% \text { of starting } \\
\text { nitrite }\end{array}$ & 100 & 100 & 91.1 & 100 & 100 & 100 & 100 \\
\hline $\begin{array}{l}\text { Destruction of Formic acid } \\
\text { charged in SRAT }\end{array}$ & $\%$ & 100 & 60 & 20.7 & 20.7 & 20.0 & 35.0 & 27.2 \\
\hline Destruction of oxalate charged & $\%$ & 50 & 50 & 50 & 50 & 50 & 50 & 50 \\
\hline $\begin{array}{lll}\text { Percent Koopman Acid in } \\
\text { Excess Stoichiometric Ratio }\end{array}$ & $\%$ & 97 & 150 & 103 & 100 & 100 & 150 & 150 \\
\hline SRAT Product Target Solids & $\%$ & 25 & 25 & 25 & 25 & 25 & 25 & 25 \\
\hline Nitric Acid Molarity & Molar & 10.53 & 10.60 & 10.40 & 10.40 & 10.60 & 10.53 & 10.40 \\
\hline Formic Acid Molarity & Molar & 23.80 & 23.80 & 23.84 & 23.84 & 23.80 & 23.80 & 23.84 \\
\hline $\begin{array}{llll}\text { Scaled Nitric } & \text { Acid addition } \\
\text { Rate } & & & \\
\end{array}$ & gallons per minute & 2 & 2 & 2 & 2 & 2 & 2 & 2 \\
\hline $\begin{array}{l}\text { Scaled Formic Acid addition } \\
\text { Rate }\end{array}$ & gallons per minute & 2 & 2 & 2 & 2 & 2 & 2 & 2 \\
\hline REDOX Target & $\mathrm{Fe}^{+2} / \Sigma \mathrm{Fe}$ & 0.2 & 0.2 & 0.2 & 0.2 & 0.2 & 0.2 & 0.2 \\
\hline $\begin{array}{lll}\text { Trimmed Sludge } & \text { Target } \mathrm{Ag} \\
\text { metal content } & & \\
\end{array}$ & $\begin{array}{c}\text { total } w \mathrm{t} \% \text { dry } \\
\text { basis } \\
\end{array}$ & 0.0108 & 0.0108 & 0.0123 & 0.0119 & 0.0142 & 0.0142 & 0.0119 \\
\hline $\begin{array}{l}\text { Trimmed Sludge Target } \mathrm{wt} \% \\
\text { Hg dry basis }\end{array}$ & $\begin{array}{c}\text { total } \mathrm{wt}_{\mathrm{t}} \% \text { dry } \\
\text { basis }\end{array}$ & 1.23 & 1.23 & 1.40 & 1.35 & 1.62 & 1.62 & 1.35 \\
\hline $\begin{array}{lll}\text { Trimmed Sludge } & \text { Target } & \text { Pd } \\
\text { metal content }\end{array}$ & $\begin{array}{c}\text { total } \mathrm{wt} \% \text { dry } \\
\text { basis } \\
\end{array}$ & 0.0050 & 0.0050 & 0.0057 & 0.0055 & 0.0066 & 0.0066 & 0.0055 \\
\hline $\begin{array}{lll}\begin{array}{l}\text { Trimmed Sludge } \\
\text { metal content }\end{array} & \text { Target } \mathrm{Rh} \\
\end{array}$ & $\begin{array}{c}\text { total } \mathrm{wt}_{\mathrm{t}} \% \text { dry } \\
\text { basis } \\
\end{array}$ & 0.0177 & 0.0177 & 0.0202 & 0.0195 & 0.0233 & 0.0233 & 0.0195 \\
\hline $\begin{array}{l}\text { Trimmed Sludge } \text { Target } \mathrm{Ru} \\
\text { metal content }\end{array}$ & $\begin{array}{l}\text { total } w t \% \text { dry } \\
\text { basis }\end{array}$ & 0.0850 & 0.0850 & 0.0962 & 0.0937 & 0.1121 & 0.1121 & 0.0937 \\
\hline $\begin{array}{l}\text { Wt\% Active Agent In Antifoam } \\
\text { Solution }\end{array}$ & $\%$ & 10 & 10 & 10 & 10 & 10 & 10 & 10 \\
\hline 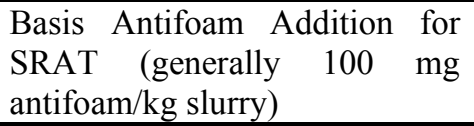 & $\mathrm{mg} / \mathrm{kg}$ slurry & 100 & 100 & 100 & 100 & 100 & 100 & 100 \\
\hline $\begin{array}{l}\text { Number of basis antifoam ad } \\
\text { SRAT cycle }\end{array}$ & ns added during & 8 & 8 & 8 & 8 & 8 & 8 & 1212 \\
\hline
\end{tabular}


SRNL-STI-2010-00589

Revision 0

Table 3-8 SME Processing Parameters and Assumptions

\begin{tabular}{|c|c|c|}
\hline Description & Units & $\begin{array}{c}\text { SB10- } \\
1,2,3,5,7,8,9\end{array}$ \\
\hline Frit type & $\mathrm{N} / \mathrm{A}$ & 418 \\
\hline Destruction of Formic acid in SME & $\%$ & 5.0 \\
\hline Destruction of Nitrate in SME & $\%$ & 5.0 \\
\hline Assumed SME density & $\mathrm{kg} / \mathrm{L}$ & 1.450 \\
\hline Basis Antifoam Addition for SME cycle & $\mathrm{mg} / \mathrm{kg}$ slurry & 100 \\
\hline Number of basis antifoam additions added during SME cycle & $\mathrm{N} / \mathrm{A}$ & 6 \\
\hline Sludge Oxide Contribution in SME (Waste Loading) & $\%$ & 38 \\
\hline Frit Slurry Formic Acid Ratio & g $90 \mathrm{wt} \% \mathrm{FA} / 100 \mathrm{~g}$ Frit & 1.50 \\
\hline Target SME Solids total $\mathrm{Wt} \%$ & $\mathrm{wt} \%$ & 50.0 \\
\hline Number of frit additions in SME Cycle & N/A & 2 \\
\hline
\end{tabular}

\subsubsection{Acid Calculation Results}

Three different acid addition predictions were used. The Hsu equation, an equation with inputs for total base, slurry carbonate, nitrite, manganese and mercury, has been used for estimating the acid requirement in DWPF since startup. Two new acid equations ${ }^{9}$, which more accurately predict the acid requirement in DWPF, have been developed. The Koopman equation adds inputs for supernate (not slurry) carbonate, calcium and magnesium to better predict the acid requirement. The acid calculation determines the values for a large number of processing parameters as well as the amount of formic and nitric acid to be used. Selected values are shown in Table 3-6. The stoichiometric acid addition for the sludge simulant was calculated to be 1.61 moles per liter for SB6-A and 1.83 moles per liter for SB6-B. The cation equation uses cations (manganese, sodium, potassium, mercury, cesium, strontium, calcium, nickel, and magnesium) to predict the acid demand with credits for anions (nitrite, nitrate, sulfate, chloride, formate and phosphate). Both of these new equations were developed for minimum acid (just enough acid to destroy nitrite with very little hydrogen generation) and nominal acid (enough acid to destroy nitrite, reduce mercury, and without making too much hydrogen). The minimum Koopman equation's prediction of acid requirement was used throughout the testing and the other results are summarized in Table 3-6.

The acid calculation determines the values for a large number of processing parameters as well as the amount of formic and nitric acid to be used. Selected values are shown in Table 3-9. The stoichiometric acid addition for the sludge simulant was calculated to be 1.61 moles per liter for SB10-A and 1.83 moles per liter for SB10-B. The minimum stoichiometric acid requirement is based on a new acid addition equation developed by David Koopman. ${ }^{14}$ As acid stoichiometry increased, the ratio of formic acid to the total amount of acid decreased. This decrease is due to the presence of nitrate and nitrite in the initial sludge simulant lowering the amount of nitrate or oxidizers needed to balance the formic acid at lower acid stoichiometries. The frit addition increased slightly due to the process samples being more dilute in terms of the original feed as acid stoichiometry increased. 
Table 3-9 Selected Process Values for Testing

\begin{tabular}{|c|c|c|c|c|c|}
\hline $\begin{array}{c}\text { Run } \\
\text { Number }\end{array}$ & $\begin{array}{c}\text { Sludge } \\
\text { Blend }\end{array}$ & $\begin{array}{c}\text { Acid } \\
\text { Stoichiometry }\end{array}$ & $\begin{array}{c}\text { Total Acid } \\
\text { Required } \\
\text { (mol/L) }\end{array}$ & $\begin{array}{c}\text { Formic Acid } \\
\text { Ratio (\% of } \\
\text { Total Acid) }\end{array}$ & $\begin{array}{c}\text { Frit Addition } \\
\text { Amount (grams) }\end{array}$ \\
\hline SB10-1 & $0 \% \mathrm{~A}$ & 97 & 1.31 & $14.09 \%$ & 535.92 \\
\hline SB10-2 & $0 \% \mathrm{~A}$ & 150 & 2.03 & $25.60 \%$ & 543.55 \\
\hline SB10-3 & $32.03 \% \mathrm{~A}$ & 103 & 1.46 & $23.40 \%$ & 587.31 \\
\hline SB10-5 & $66.30 \% \mathrm{~A}$ & 100 & 1.57 & $44.70 \%$ & 637.62 \\
\hline SB10-7 & $100 \% \mathrm{~A}$ & 100 & 1.69 & $73.53 \%$ & 691.16 \\
\hline SB10-8 & $100 \% \mathrm{~A}$ & 150 & 2.53 & $74.41 \%$ & 695.81 \\
\hline SB10-9 & $32.02 \% \mathrm{~A}$ & 150 & 2.50 & $38.79 \%$ & 593.56 \\
\hline
\end{tabular}

\subsubsection{SRAT Cycle Processing Observations}

Overall processing during the testing went smoothly with no interruptions or upsets occurring during process runs. The sludge became less viscous during acid additions and no problems were noted with mixing during the runs. Agitator speeds of $250 \mathrm{RPM}^{2}$ were sufficient to mix the sludge simulants.

\subsubsection{SRAT Cycle Foaming}

The FBSR PDT slurry is high in carbonate. Approximately $80 \%$ of the soluble carbonate is washed out of the slurry during sludge preparation. However the carbonate concentration in the SB10-B slurry was approximately $1.5 \mathrm{X}$ higher than the SB10-A slurry. Since carbonate is neutralized during acid addition and $\mathrm{CO}_{2}$ is evolved, the excess carbonate means that $\mathrm{CO}_{2}$ continues evolving for a long time during acid addition so there is a potential for more foaming in testing with the SB10-B slurry. However, no foaming was noted in any of the experiments. No additional antifoam was required during any of the seven experiments. Note that the SB10-9 experiment had additional antifoam added because of the longer processing time and higher antifoam addition during caustic boiling (ARP addition).

\subsubsection{SRAT Cycle pH Profiles}

The $\mathrm{pH}$ profiles of the seven runs in general matched profiles noted during previous CPC simulations. ${ }^{17}$ As shown in Figure 3-3 the $\mathrm{pH}$ of the runs was lower for runs with coal and little change in $\mathrm{pH}$ occurred during boiling in runs with coal. Formic acid decomposition during high acid, no coal runs resulted in a higher final $\mathrm{pH}$.

\footnotetext{
${ }^{2}$ The mixing geometry of the lab-scale apparatus is not prototypic of the DWPF SRAT/SME vessels and mixing was adjusted as required during testing to ensure that the process chemistry was captured. Agitator speed is reported only to give an indication of changes in rheological properties during the testing.
} 


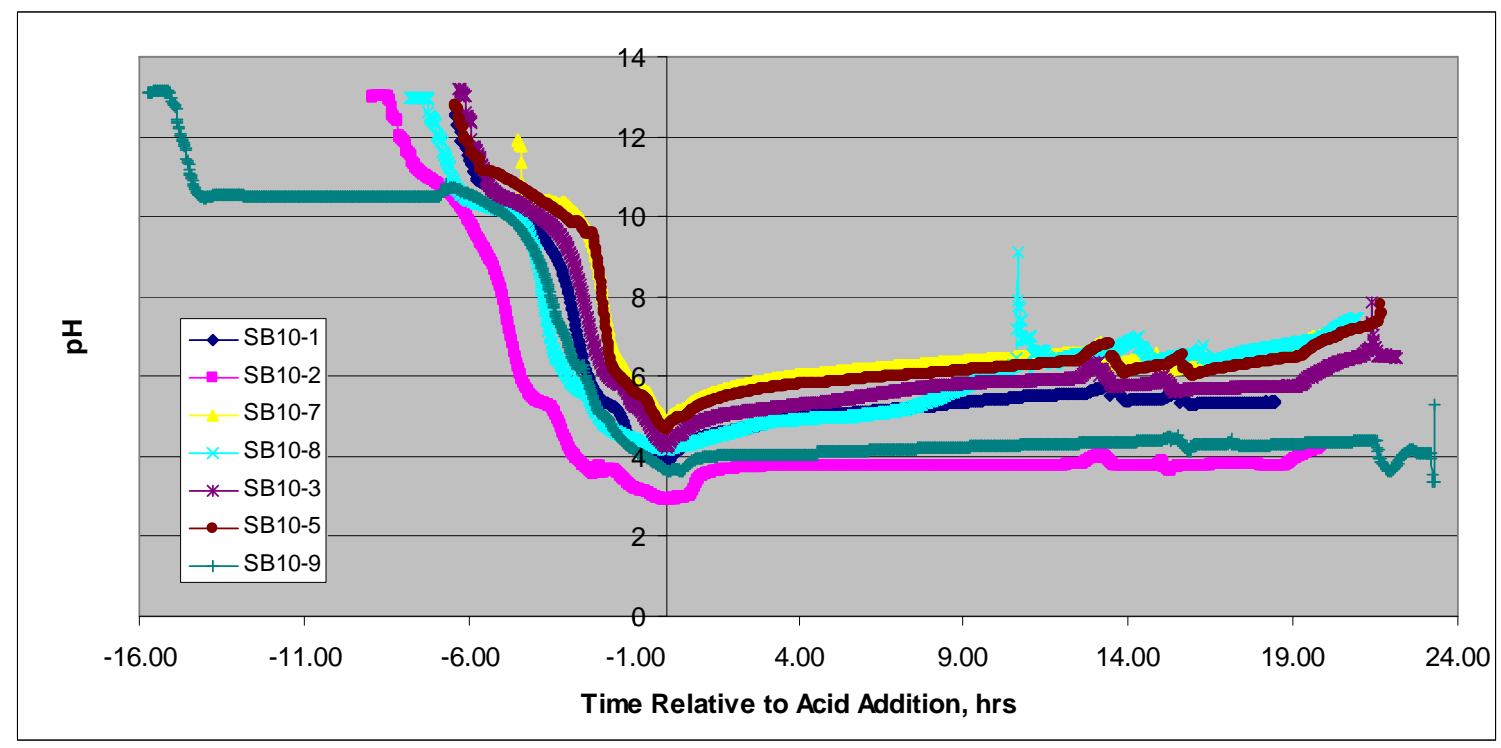

Figure 3-3. CPC Flowsheet Testing pH Profiles

\subsubsection{SRAT Cycle Sample Results}

Samples were pulled throughout and at the conclusion of the SRAT cycle. The total solids, mercury, anions, and soluble elemental species were analyzed for all samples. Samples were taken of the SRAT dewater and the MWWT contents at the completion of the SRAT cycle. All sample results are tabulated in Appendix B.

\subsubsection{Nitrite, Nitrate, Formate}

Nitrite destruction met the process requirement of $<1000 \mathrm{mg} / \mathrm{kg}$ slurry at the end of the SRAT cycle for all runs except the low acid stoichiometry run with SB10-A simulant (no coal). For all runs with coal, there was no detectable nitrite at the end of the SRAT cycle. Note that the total time at boiling was 12 hours for each of these experiments. Anion results are summarized in Table 3-10.

Table 3-10 SRAT Product Anion Concentration from Tests, mg/kg slurry

\begin{tabular}{|c|c|c|c|c|c|c|c|}
\hline $\begin{array}{c}\text { Run ID \& Acid } \\
\text { Stoichiometry }\end{array}$ & $\mathbf{F}$ & $\mathbf{C l}$ & $\mathbf{N O}_{2}$ & $\mathbf{N O}_{3}$ & $\mathbf{S O}_{4}$ & $\mathbf{P O}_{4}$ & $\mathbf{H C O}_{2}$ \\
\hline $100 \%$ SB10-1 & $<100$ & $<100$ & $<100$ & 68,100 & $<100$ & $<100$ & 11,800 \\
\hline $150 \%$ SB10-2 & $<100$ & $<100$ & $<100$ & 65,450 & $<100$ & $<100$ & 24,800 \\
\hline $100 \%$ SB10-3 & $<100$ & 361 & $<100$ & 64,100 & $<100$ & $\mathrm{NM}$ & 18,350 \\
\hline $100 \%$ SB10-5 & $<100$ & 291 & $<100$ & 41,450 & $<100$ & $\mathrm{NM}$ & 37,100 \\
\hline $100 \%$ SB10-7 & $<100$ & $<100$ & 1315 & 18,150 & $<100$ & $<100$ & 53,250 \\
\hline $150 \%$ SB10-8 & $<100$ & $<100$ & $<100$ & 17,150 & $<100$ & $<100$ & 59,300 \\
\hline $150 \%$ SB10-9 & $<100$ & 295 & $<100$ & 56,800 & $<100$ & $\mathrm{NM}$ & 36,200 \\
\hline
\end{tabular}

In a "typical run", approximately one-third of the nitrite is converted to nitrate and the other twothirds are converted to $\mathrm{NO}_{\mathrm{x}}$ and $\mathrm{N}_{2} \mathrm{O}$. In all of these runs (Table 3-11), some additional nitrate was present in the SRAT product due to the destruction of nitrite. However, in four of these runs, 
(SB10-1, 2, 7, and 8) all lost significant nitrate (negative nitrite to nitrate conversion) suggesting that ammonia was likely produced during testing both with and without coal.

Formate is destroyed by reduction of $\mathrm{Mn}, \mathrm{Hg}$ and catalytic destruction of nitrite ion to primarily produce $\mathrm{NO}, \mathrm{N}_{2} \mathrm{O}, \mathrm{NO}_{2}$, and $\mathrm{CO}_{2}$. Formic acid is destroyed catalytically to produce primarily $\mathrm{CO}_{2}$, and hydrogen. An overall trend of higher formate loss with higher acid stoichiometry is indicated, which matches previous results and the amount of formate loss is consistent with previous testing.

Table 3-11 SRAT Anion Conversions

\begin{tabular}{|c|c|c|c|}
\hline \multirow{2}{*}{$\begin{array}{c}\text { Run ID \& } \\
\text { Acid } \\
\text { Stoichiometry }\end{array}$} & $\begin{array}{c}\text { Sormate } \\
\text { Destruction }\end{array}$ & $\begin{array}{c}\text { SRAT Cycle } \\
\text { Nitrite to } \\
\text { Nonversion }\end{array}$ & $\begin{array}{c}\text { Nitrite } \\
\text { Destruction }\end{array}$ \\
\cline { 2 - 4 } & $36.6 \%$ & $-7.9 \%$ & $100 \%$ \\
\hline SB10-1 97\% & $36.0 \%$ & $-32.4 \%$ & $100 \%$ \\
\hline SB10-2 150\% & $42.5 \%$ & $1.2 \%$ & $100 \%$ \\
\hline SB10-3 103\% $\%$-5 100\% & $24.9 \%$ & $7.6 \%$ & $100 \%$ \\
\hline SB10-7 100\% & $13.4 \%$ & $-5.3 \%$ & $87.0 \%$ \\
\hline SB10-8 150\% & $28.9 \%$ & $-37.2 \%$ & $100 \%$ \\
\hline SB10-9 150\% & $26.3 \%$ & $22.8 \%$ & $100 \%$ \\
\hline
\end{tabular}

\subsubsection{Mercury}

The SRAT product samples were analyzed for mercury content to evaluate the stripping of mercury during the SRAT cycle. The current DWPF SRAT product target is $0.6 \mathrm{wt} \%$ (solids basis) mercury to meet process specifications. The mercury concentration in the six hour sample and in the SRAT product sample (12-hour of boiling) is summarized in Table 3-12 and Figure 3-4.

Table 3-12 SRAT Product Mercury Results

\begin{tabular}{|c|c|c|c|c|}
\hline $\begin{array}{c}\text { Run ID \& Acid } \\
\text { Stoichiometry }\end{array}$ & $\begin{array}{c}\text { Calculated } \\
\text { Initial Mercury } \\
\text { (Wt \% Total } \\
\text { Solid Basis) }\end{array}$ & $\begin{array}{c}\text { SRAT 6-hour } \\
\text { Mercury } \\
\text { (Wt \% Total } \\
\text { Solids Basis) }\end{array}$ & $\begin{array}{c}\text { SRAT Product } \\
\text { Mercury } \\
\text { (Wt \% Total } \\
\text { Solids Basis) }\end{array}$ & $\begin{array}{c}\text { SME Product } \\
\text { Mercury } \\
\text { (Wt \% Total } \\
\text { Solids Basis) }\end{array}$ \\
\hline SB10-1 97\% & $1.05 \%$ & $0.62 \%$ & $0.45 \%$ & $0.22 \%$ \\
\hline SB10-2 150\% & $0.92 \%$ & $0.60 \%$ & $0.39 \%$ & $0.01 \%$ \\
\hline SB10-3 103\% & $1.09 \%$ & $0.80 \%$ & $0.65 \%$ & $0.19 \%$ \\
\hline SB10-5 150\% & $1.26 \%$ & $0.86 \%$ & $0.59 \%$ & $0.18 \%$ \\
\hline SB10-7 100\% & $1.38 \%$ & $1.02 \%$ & $0.89 \%$ & $0.52 \%$ \\
\hline SB10-8 $150 \%$ & $1.28 \%$ & $0.01 \%$ & $0.01 \%$ & $0.00 \%$ \\
\hline SB10-9 $150 \%$ & $1.03 \%$ & $0.68 \%$ & $0.27 \%$ & $0.06 \%$ \\
\hline
\end{tabular}




\subsubsection{SRAT Product Solids, Density, and $p H$}

The solids, density and $\mathrm{pH}$ results are summarized in Table 3-13. The total solids target for the runs was $25 \mathrm{wt} \%$ so the measured solids is higher than targeted for all runs. The insoluble solids and $\mathrm{pH}$ results are lowest for run SB10-2 (highest coal-carbon, 150\% acid stoichiometry) and the supernate density was highest. This demonstrates that more of the insoluble solids were dissolved in the high acid runs with coal-carbon. Nitric acid is a stronger acid (pKa -1.5) compared to formic acid (pKa 3.75). In addition, less nitric acid is consumed due to catalytic reactions so the resulting SRAT product $\mathrm{pH}$ is much lower for the runs with coal-carbon than without coal-carbon.

Table 3-13 SRAT Product Solids, Density, and pH Results

\begin{tabular}{||c|c|c|c|c||c|c|c||}
\hline \hline Run ID & $\begin{array}{c}\text { Total } \\
\text { Solids } \\
\text { wt \% }\end{array}$ & $\begin{array}{c}\text { Insoluble } \\
\text { Solids } \\
\text { wt \% }\end{array}$ & $\begin{array}{c}\text { Soluble } \\
\text { Solids } \\
\text { wt \% }\end{array}$ & $\begin{array}{c}\text { Calcined } \\
\text { Solids } \\
\text { wt \% }\end{array}$ & $\begin{array}{c}\text { Slurry } \\
\text { Density } \\
\text { g/mL }\end{array}$ & $\begin{array}{c}\text { Supernate } \\
\text { Density } \\
\text { g/mL }\end{array}$ & pH \\
\hline SB10-1 & 27.87 & 15.69 & 12.19 & 17.29 & 1.165 & 1.1001 & 6.52 \\
\hline SB10-2 & 25.29 & 11.99 & 13.30 & 17.43 & 1.213 & 1.1159 & 3.85 \\
\hline SB10-3 & 26.98 & 15.25 & 11.74 & 18.70 & 1.214 & Not Measured & 6.87 \\
\hline SB10-5 & 27.18 & 15.57 & 11.61 & 17.48 & 1.207 & Not Measured & 7.47 \\
\hline SB10-7 & 27.63 & 16.79 & 10.85 & 16.94 & 1.232 & 1.0856 & 7.37 \\
\hline SB10-8 & 26.49 & 15.46 & 11.03 & 17.48 & 1.210 & 1.0865 & 7.91 \\
\hline SB10-9 & 26.82 & 13.31 & 13.51 & 16.63 & 1.221 & Not Measured & 4.61 \\
\hline
\end{tabular}

\subsubsection{SRAT Slurry and Filtrate Sample ICP-AES Results}

The slurry elemental results from Inductively Coupled Plasma - Atomic Emission Spectroscopy (ICP-AES) analyses are summarized in Table 3-14, and the filtrate elemental results from ICPAES analyses are summarized in Table 3-15. The solubility of each element was then calculated based on these results and summarized in Table 3-16. In runs SB10-2 and SB10-9, both high acid runs with coal-carbon, iron and nickel are moderately soluble compared to being insoluble in the rest of the experiments. 
SRNL-STI-2010-00589

Revision 0

Table 3-14 SRAT ICP-AES Slurry Results, wt \% Calcined Solids Basis

\begin{tabular}{|c|c|c|c|c|c|c|c|}
\hline Element & SB10-1 & SB10-2 & SB10-3 & SB10-5 & SB10-7 & SB10-8 & SB10-9 \\
\hline $\mathrm{Ag}$ & $<0.0100$ & $<0.0100$ & $\mathrm{NM}$ & $\mathrm{NM}$ & $<0.0100$ & $<0.0100$ & $\mathrm{NM}$ \\
\hline $\mathrm{Al}$ & 4.94 & 4.82 & 5.51 & 6.28 & 6.98 & 6.96 & 5.81 \\
\hline $\mathrm{Ba}$ & 0.24 & 0.23 & 0.23 & 0.22 & 0.21 & 0.22 & 0.20 \\
\hline $\mathrm{Ca}$ & 2.79 & 2.84 & 2.15 & 2.08 & 2.64 & 2.64 & 2.03 \\
\hline $\mathrm{Cd}$ & $<0.0100$ & $<0.0100$ & $<0.0100$ & $<0.0100$ & $<0.0100$ & $<0.0100$ & $<0.0100$ \\
\hline $\mathrm{Cr}$ & 0.16 & 0.17 & 0.14 & 0.14 & 0.16 & 0.17 & 0.12 \\
\hline $\mathrm{Cu}$ & 0.06 & 0.05 & $\mathrm{NM}$ & $\mathrm{NM}$ & 0.06 & $<0.0100$ & $\mathrm{NM}$ \\
\hline $\mathrm{Fe}$ & 30.00 & 29.80 & 29.96 & 29.27 & 28.65 & 28.35 & 25.24 \\
\hline $\mathrm{K}$ & 0.25 & 0.23 & 0.27 & 0.21 & 0.16 & 0.16 & 0.20 \\
\hline $\mathrm{Mg}$ & 0.37 & 0.39 & 0.32 & 0.31 & 0.35 & 0.40 & 0.37 \\
\hline $\mathrm{Mn}$ & 5.55 & 5.46 & 3.72 & 3.79 & 5.45 & 5.37 & 3.16 \\
\hline $\mathrm{Na}$ & 12.75 & 12.60 & 13.78 & 14.46 & 13.25 & 13.30 & 16.52 \\
\hline $\mathrm{Ni}$ & 0.80 & 0.83 & 0.72 & 0.71 & 0.76 & 0.84 & 0.61 \\
\hline $\mathrm{P}$ & $<0.100$ & $<0.100$ & $<0.100$ & $<0.100$ & $<0.100$ & $<0.100$ & $<0.100$ \\
\hline $\mathrm{Pb}$ & $\mathrm{NM}$ & $\mathrm{NM}$ & 0.14 & 0.18 & $\mathrm{NM}$ & $\mathrm{NM}$ & 0.18 \\
\hline $\mathrm{Pd}$ & $<0.100$ & $<0.100$ & $<0.100$ & $<0.100$ & $<0.100$ & $<0.100$ & $<0.100$ \\
\hline $\mathrm{Rh}$ & 0.02 & 0.02 & 0.09 & 0.09 & 0.02 & 0.02 & 0.07 \\
\hline $\mathrm{Ru}$ & $<0.100$ & $<0.100$ & $<0.100$ & $<0.100$ & $<0.100$ & $<0.100$ & $<0.100$ \\
\hline $\mathrm{S}$ & 0.08 & 0.08 & $<0.100$ & $<0.100$ & 0.07 & 0.08 & $<0.100$ \\
\hline $\mathrm{Si}$ & 3.05 & 3.02 & 2.56 & 2.31 & 2.02 & 2.04 & 2.22 \\
\hline $\mathrm{Sn}$ & 0.04 & 0.04 & 0.08 & 0.04 & 0.03 & 0.04 & 0.18 \\
\hline $\mathrm{Ti}$ & 0.15 & 0.15 & 0.085 & 0.037 & $<0.0100$ & $<0.0100$ & 2.33 \\
\hline $\mathrm{Zn}$ & 0.08 & 0.08 & 0.07 & 0.07 & 0.07 & 0.08 & 0.07 \\
\hline $\mathrm{Zr}$ & 0.44 & 0.44 & 0.44 & 0.46 & 0.47 & 0.51 & 0.40 \\
\hline
\end{tabular}

Note that the sum of the oxides was between 87.6 and 92.5 for all analyses. Typically this is between 95 and 105 so the samples may not have been completely digested. Note that the sum of the oxides for the SME products were all between 95 and 105. 
Table 3-15 SRAT Product ICP-AES Filtrate Results, mg/L

\begin{tabular}{|c|c|c|c|c|c|c|c|}
\hline Element & SB10-1 & SB10-2 & SB10-3 & SB10-5 & SB10-7 & SB10-8 & SB10-9 \\
\hline $\mathrm{Ag}$ & $<0.010$ & $<0.010$ & $<0.100$ & $<0.100$ & $<0.010$ & $<0.010$ & $<0.100$ \\
\hline $\mathrm{Al}$ & 0.98 & 92.37 & 1.86 & 1.90 & 0.88 & 0.92 & 26.83 \\
\hline $\mathrm{B}$ & 7.13 & 37.55 & 54.53 & 18.97 & 3.71 & 3.50 & 0.71 \\
\hline $\mathrm{Ca}$ & 5,455 & 5,180 & 5,550 & 5,132 & 4,380 & 4,505 & 3,796 \\
\hline $\mathrm{Cd}$ & $\mathrm{NM}$ & $\mathrm{NM}$ & $<0.010$ & $<0.010$ & $\mathrm{NM}$ & $\mathrm{NM}$ & $<0.010$ \\
\hline $\mathrm{Ce}$ & 2.38 & 403.55 & $\mathrm{NM}$ & $\mathrm{NM}$ & 0.28 & 1.73 & $\mathrm{NM}$ \\
\hline $\mathrm{Cr}$ & $<0.010$ & 0.55 & 0.26 & $<0.010$ & $<0.010$ & $<0.010$ & 0.84 \\
\hline $\mathrm{Cu}$ & 0.08 & 6.84 & 0.95 & 0.93 & 0.07 & 0.15 & 5.51 \\
\hline $\mathrm{Fe}$ & $<0.010$ & 5,160 & $<0.010$ & $<0.010$ & $<0.010$ & $<0.010$ & 674 \\
\hline $\mathrm{K}$ & 975 & 826 & 1,142 & 973 & 848 & 811 & 852 \\
\hline $\mathrm{La}$ & 0.17 & 205.20 & $\mathrm{NM}$ & $\mathrm{NM}$ & $<0.010$ & $<0.010$ & $\mathrm{NM}$ \\
\hline $\mathrm{Li}$ & 3.54 & 3.87 & $\mathrm{NM}$ & $\mathrm{NM}$ & 2.36 & 2.48 & $\mathrm{NM}$ \\
\hline $\mathrm{Mg}$ & 562 & 625 & 471 & 436 & 503 & 571 & 635 \\
\hline $\mathrm{Mn}$ & 4,215 & 11,000 & 3,796 & 1,008 & 670 & 2,615 & 9,579 \\
\hline $\mathrm{Mo}$ & 0.59 & 0.35 & $\mathrm{NM}$ & $\mathrm{NM}$ & 0.70 & 0.41 & $\mathrm{NM}$ \\
\hline $\mathrm{Na}$ & 32,600 & 25,300 & $\mathrm{NM}$ & $\mathrm{NM}$ & 38,450 & 35,900 & $\mathrm{NM}$ \\
\hline $\mathrm{Ni}$ & 0.42 & 675 & 0.26 & $<0.010$ & $<0.010$ & $<0.010$ & 167 \\
\hline $\mathrm{Pr}$ & $\mathrm{NM}$ & $\mathrm{NM}$ & $<1.00$ & $<1.00$ & $\mathrm{NM}$ & $\mathrm{NM}$ & $<1.00$ \\
\hline $\mathrm{Pb}$ & $\mathrm{NM}$ & $\mathrm{NM}$ & $<0.010$ & $<0.010$ & $\mathrm{NM}$ & $\mathrm{NM}$ & $<0.010$ \\
\hline $\mathrm{Pd}$ & $\mathrm{NM}$ & $\mathrm{NM}$ & 0.15 & 0.14 & $\mathrm{NM}$ & $\mathrm{NM}$ & 0.09 \\
\hline $\mathrm{Pr}$ & 2.02 & 5.79 & 2.74 & 2.30 & 1.54 & 1.56 & 1.57 \\
\hline $\mathrm{Rh}$ & $\mathrm{NM}$ & $\mathrm{NM}$ & 0.52 & 0.48 & $\mathrm{NM}$ & $\mathrm{NM}$ & 0.51 \\
\hline $\mathrm{Ru}$ & $\mathrm{NM}$ & $\mathrm{NM}$ & $<0.010$ & $<0.010$ & $\mathrm{NM}$ & $\mathrm{NM}$ & $<0.010$ \\
\hline $\mathrm{S}$ & 19.67 & 23.62 & 24.83 & 35.37 & 41.04 & 30.94 & 263.1 \\
\hline $\mathrm{Si}$ & 25.48 & 77.01 & 22.16 & 13.10 & 9.04 & 23.84 & 94.67 \\
\hline $\mathrm{Sr}$ & 17.50 & 18.40 & $\mathrm{NM}$ & $\mathrm{NM}$ & 3.69 & 4.16 & $\mathrm{NM}$ \\
\hline $\mathrm{Ti}$ & $<0.010$ & $<0.010$ & $<0.010$ & $<0.010$ & $<0.010$ & $<0.010$ & $<0.010$ \\
\hline $\mathrm{Zn}$ & $<0.010$ & 15.34 & $<0.010$ & $<0.010$ & $<0.010$ & $<0.010$ & 7.40 \\
\hline $\mathrm{Zr}$ & $<0.010$ & 0.16 & 0.02 & 0.02 & $<0.010$ & $<0.010$ & 0.06 \\
\hline
\end{tabular}

$\mathrm{NM}=$ Not Measured 
Table 3-16 SRAT Product Percent of ICP-ES Elements Soluble

\begin{tabular}{|c|c|c|c|c|c|c|c|}
\hline Element & SB10-1 & SB10-2 & SB10-3 & SB10-5 & SB10-7 & SB10-8 & SB10-9 \\
\hline $\mathrm{Al}$ & $0.0 \%$ & $1.0 \%$ & $0.0 \%$ & $0.0 \%$ & $0.0 \%$ & $0.0 \%$ & $0.2 \%$ \\
\hline B & $1.3 \%$ & $8.3 \%$ & $10.6 \%$ & $3.5 \%$ & $0.7 \%$ & $0.7 \%$ & $0.2 \%$ \\
\hline $\mathrm{Ca}$ & $86.8 \%$ & $94.6 \%$ & $113.7 \%$ & $101.2 \%$ & $65.1 \%$ & $71.2 \%$ & $88.8 \%$ \\
\hline $\mathrm{Cr}$ & LDL & $0.2 \%$ & $0.1 \%$ & LDL & LDL & LDL & $0.3 \%$ \\
\hline $\mathrm{Cu}$ & $0.1 \%$ & $7.0 \%$ & $\mathrm{NM}$ & $\mathrm{NM}$ & $0.0 \%$ & LDL & NM \\
\hline $\mathrm{Fe}$ & LDL & $9.0 \%$ & LDL & LDL & LDL & LDL & $1.3 \%$ \\
\hline K & $171.1 \%$ & $190.1 \%$ & $187.6 \%$ & $189.9 \%$ & $202.0 \%$ & $211.2 \%$ & $200.1 \%$ \\
\hline $\mathrm{La}$ & $\mathrm{NM}$ & NM & $0.0 \%$ & $0.0 \%$ & LDL & LDL & $0.0 \%$ \\
\hline $\mathrm{Li}$ & NM & $\mathrm{NM}$ & $0.0 \%$ & $0.0 \%$ & $\mathrm{NM}$ & NM & $0.0 \%$ \\
\hline $\mathrm{Mg}$ & $67.7 \%$ & $83.9 \%$ & $65.2 \%$ & $57.6 \%$ & $55.6 \%$ & $59.4 \%$ & $80.8 \%$ \\
\hline $\mathrm{Mn}$ & $33.7 \%$ & $104.6 \%$ & $45.0 \%$ & $10.9 \%$ & $4.8 \%$ & $20.3 \%$ & $143.7 \%$ \\
\hline Mo & NM & NM & $0.0 \%$ & $0.0 \%$ & NM & NM & $0.0 \%$ \\
\hline $\mathrm{Na}$ & $113.3 \%$ & $104.2 \%$ & $\mathrm{NM}$ & $\mathrm{NM}$ & $113.7 \%$ & $112.3 \%$ & $\mathrm{NM}$ \\
\hline $\mathrm{Ni}$ & $0.0 \%$ & $42.2 \%$ & $0.0 \%$ & $0.0 \%$ & LDL & LDL & $12.9 \%$ \\
\hline $\mathrm{Pb}$ & $0.0 \%$ & $0.0 \%$ & LDL & LDL & $0.0 \%$ & $0.0 \%$ & LDL \\
\hline $\mathrm{Rh}$ & $0.0 \%$ & $0.0 \%$ & $0.8 \%$ & $0.8 \%$ & $0.0 \%$ & $0.0 \%$ & $1.1 \%$ \\
\hline S & $11.2 \%$ & $15.3 \%$ & $16.8 \%$ & $24.7 \%$ & $23.0 \%$ & $16.7 \%$ & $68.8 \%$ \\
\hline $\mathrm{Si}$ & $0.4 \%$ & $1.3 \%$ & $0.4 \%$ & $0.2 \%$ & $0.2 \%$ & $0.5 \%$ & $2.0 \%$ \\
\hline $\mathrm{Sn}$ & $0.0 \%$ & $0.0 \%$ & $0.0 \%$ & $0.0 \%$ & $0.0 \%$ & $0.0 \%$ & $0.0 \%$ \\
\hline $\mathrm{Sr}$ & NM & NM & $0.0 \%$ & $0.0 \%$ & NM & NM & $0.0 \%$ \\
\hline $\mathrm{Zn}$ & LDL & $10.3 \%$ & LDL & LDL & LDL & LDL & $5.1 \%$ \\
\hline $\mathrm{Zr}$ & LDL & $0.0 \%$ & $0.0 \%$ & $0.0 \%$ & LDL & LDL & $0.0 \%$ \\
\hline
\end{tabular}

\subsubsection{SRAT Cycle Offgas Composition Results}

A typical offgas concentration profile is shown in Figure 3-5, while charts from all runs are shown in Appendix C. Helium and nitrogen show reduced concentrations during periods with large quantities of offgas generation due to dilution, while oxygen showed reduced concentrations during these periods due to dilution and from consumption. In general, hydrogen generation began after nitrous oxide emissions had ceased and carbon dioxide emission was noted in conjunction with the hydrogen. The patterns of offgas emissions noted during the runs were typical of offgas generation during the SRAT cycle. 


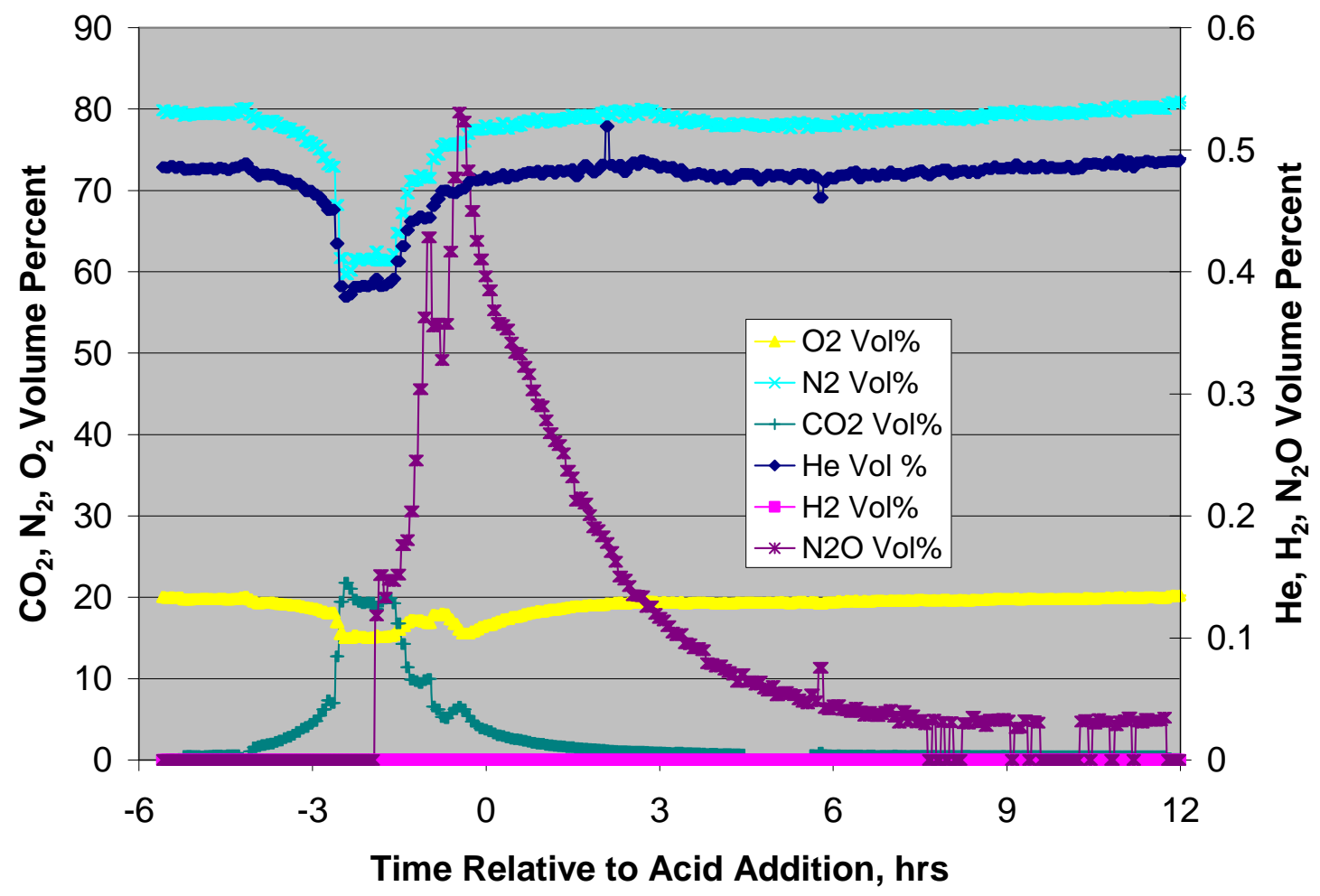

Figure 3-4. Typical SRAT Offgas Profile 100\% Acid Stoichiometry, no coal

\subsubsection{SRAT Cycle Hydrogen Evolution}

The peak hydrogen concentration for each run is shown in Figure 3-6. In general, the peak hydrogen generation rate increased with increased acid addition. Also, in runs with SB10-B sludge, very little hydrogen was formed. In the SB10-8 run with SB10-A simulant (no FBSR coal) at $150 \%$ acid stoichiometry, the hydrogen generation exceeded the DWPF SRAT processing limits of $0.65 \mathrm{lb} / \mathrm{hr}$, which shows the peak hydrogen generation after scaling to the DWPF process. It should be noted that the noble metal concentrations for these runs was conservative (SB6 levels of noble metals were used). Processing with the SB10-B simulant significantly decreased the hydrogen generation due to the low formic acid addition amounts resulting from REDOX adjustment with nitric acid due to the presence of coal. Results are shown in Table 3-17. 


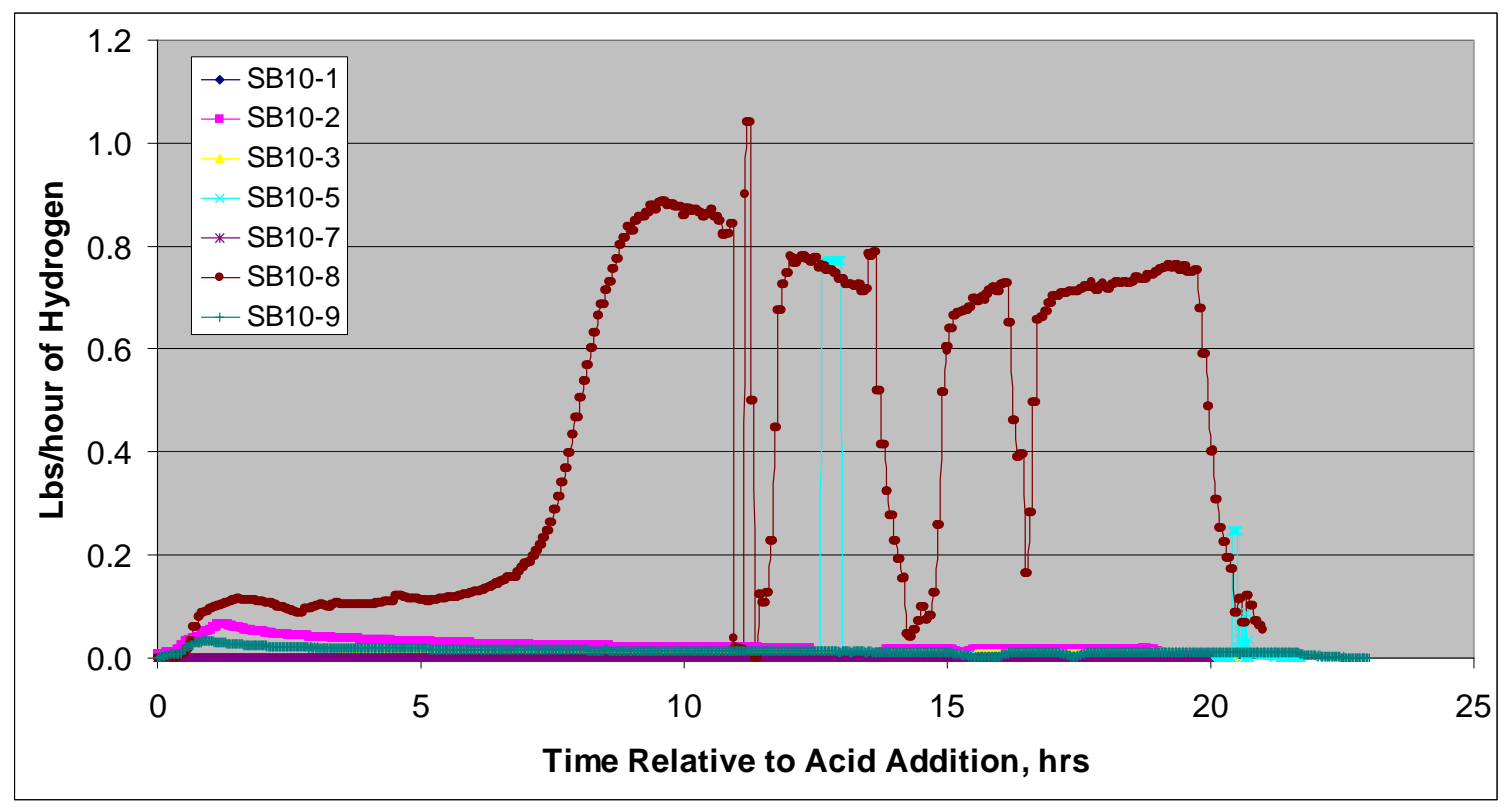

Figure 3-5. SRAT Cycle Hydrogen Peaks

Table 3-17 SRAT Cycle Hydrogen Peak Generation Rate

\begin{tabular}{|l|c|c|c|c|}
\hline Run ID & $\begin{array}{c}\text { Sludge } \\
\text { Composition }\end{array}$ & $\begin{array}{c}\text { Slurry Predicted } \\
\text { Coal, mg/kg }\end{array}$ & $\begin{array}{c}\text { Acid } \\
\text { Stoichiometry }\end{array}$ & $\begin{array}{c}\text { Hydrogen } \\
\text { (lb/hr) }\end{array}$ \\
\hline SB10-1 & $0.00 \%$ A, 100\% B & 19,800 & $97 \%$ & 0.01 \\
\hline SB10-2 & $0.00 \%$ A, 100\% B & 18,500 & $150 \%$ & 0.07 \\
\hline SB10-3 & $32.0 \%$ A, 68.0\% B & 12,900 & $103 \%$ & 0.01 \\
\hline SB10-5 & $66.3 \%$ A, 33.7\% B & 5,870 & $100 \%$ & 0.00 \\
\hline SB10-7 & $100 \%$ A, 0.00\% B & 0 & $100 \%$ & 0.00 \\
\hline SB10-8 & $100 \%$ A, 0.00\% B & 0 & $150 \%$ & 1.04 \\
\hline SB10-9 & $32.0 \%$ A, 68.0\% B & 10,000 & $150 \%$ & 0.03 \\
\hline
\end{tabular}

\subsubsection{SRAT Cycle Other Offgas Species}

The nitrous oxide peak concentrations slightly increased as acid addition was increased. The carbon dioxide peak was very similar for all runs. The peak generation of these species is less dependent on acid concentration than hydrogen since more acid is added than needed to destroy carbonate and nitrite, the compounds that are responsible for the highest emissions. The peak generation rates are shown in Table 3-18 after scaling to the DWPF process scale. 
Table 3-18 SRAT Cycle Nitrous Oxide and Carbon Dioxide Peak Generation Rates

\begin{tabular}{|c|c|c|c|c|c|}
\hline Run ID & $\begin{array}{c}\text { Sludge } \\
\text { Composition }\end{array}$ & $\begin{array}{l}\text { Slurry Predicted } \\
\text { Coal-carbon, } \\
\text { mg/kg }\end{array}$ & $\begin{array}{c}\text { Acid } \\
\text { Stoichiometry }\end{array}$ & $\begin{array}{c}\text { CO } \\
\text { (lb/hr) }\end{array}$ & $\begin{array}{c}\mathbf{N}_{\mathbf{2}} \text { O Peak } \\
\text { (lb/hr) }\end{array}$ \\
\hline SB10-1 & $0.00 \%$ A, 100\% B & 19,800 & $97 \%$ & 323 & 6.95 \\
\hline SB10-2 & $0.00 \%$ A, 100\% B & 18,500 & $150 \%$ & 500 & 13.14 \\
\hline SB10-3 & $32.0 \%$ A, 68.0\% B & 12,900 & $103 \%$ & 422 & 10.50 \\
\hline SB10-5 & $66.3 \%$ A, 33.7\% B & 5,870 & $100 \%$ & 438 & 7.19 \\
\hline SB10-7 & $100 \%$ A, 0.00\% B & 0 & $100 \%$ & 533 & 10.56 \\
\hline SB10-8 & $100 \%$ A, 0.00\% B & 0 & $150 \%$ & 459 & 47.79 \\
\hline SB10-9 & $32.0 \%$ A, 68.0\% B & 10,000 & $150 \%$ & 233 & 19.23 \\
\hline
\end{tabular}

The volumes of both carbon dioxide and nitrous oxide generated were smaller in runs with coal (SB10-1, SB10-2) compared to runs without coal (SB10-7, SB10-8), Figure 3-7. Since the sodium carbonate concentration in runs with coal was $1.5 \mathrm{X}$ the runs without coal, this was unexpected. It was expected that more $\mathrm{CO}_{2}$ would be produced during runs with the coal but that did not happen. More $\mathrm{CO}_{2}$ production would increase the potential for foam during acid addition.

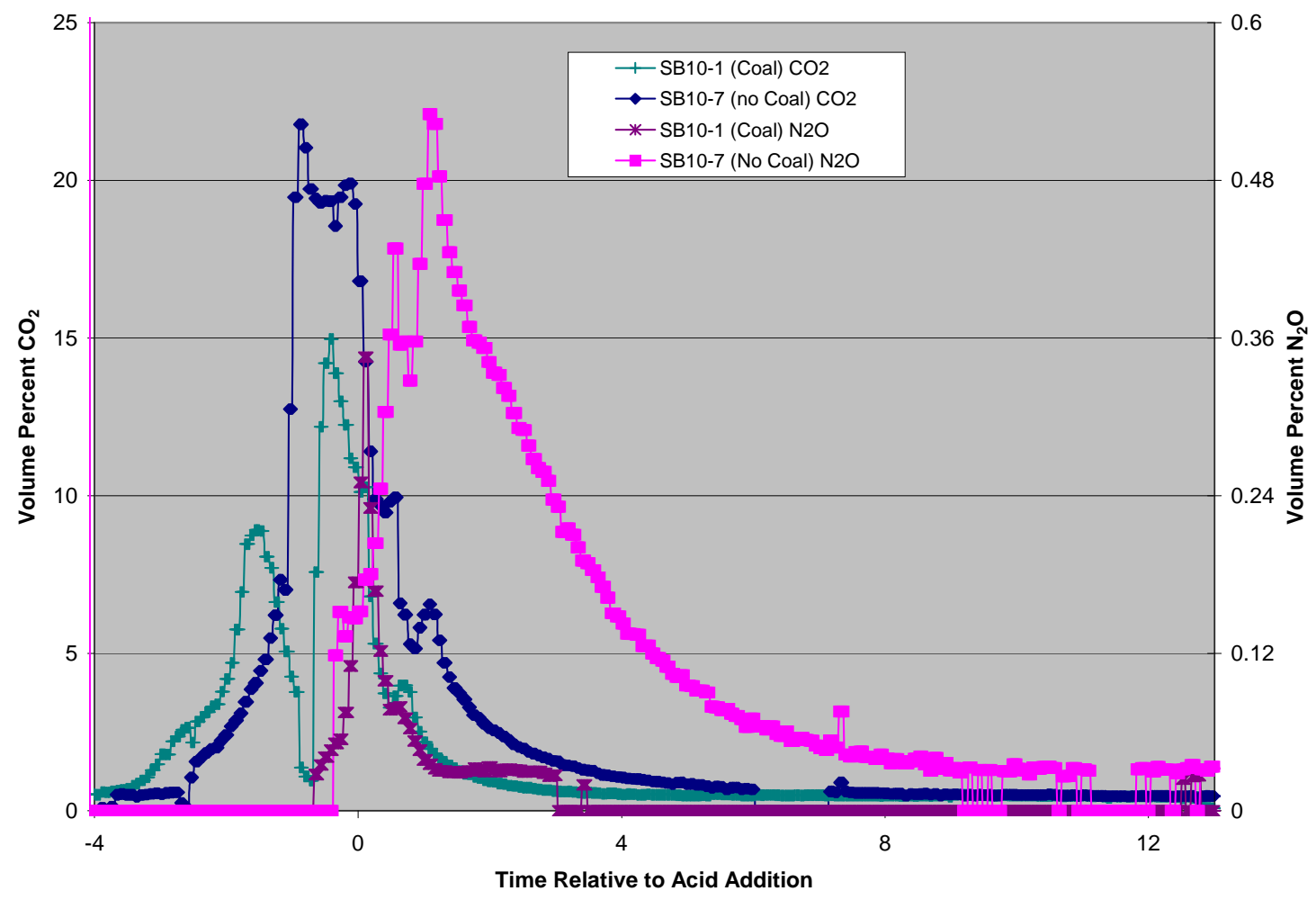

Figure 3-6. Carbon Dioxide and Nitrous Oxide Concentration in Runs SB10-2 and SB10-8 SRAT Cycle 


\subsubsection{SRAT Product Rheological Properties}

The rheological properties of SRAT products were measured for the four runs produced with the simulant (SB10-A). The rheological properties were outside the design basis limits for yield stress or consistency for SRAT products (yield stress 1.5 to $5 \mathrm{~Pa}$ and Consistency 5 to $12 \mathrm{cP}$ ) except for the low acid, high coal run (SB10-1) and the high acid, no coal run (SB10-8) which was within the limits for yield stress and consistency. The yield stress and consistency of the SRAT products are shown in Table 3-19. Note that the high acid runs with coal had very low yield stress values so could have been further concentrated.

Table 3-19 SRAT Product Rheological Properties

\begin{tabular}{|c|c|c|c|c|c|}
\hline Run ID & $\begin{array}{c}\text { Acid } \\
\text { \% }\end{array}$ & $\begin{array}{c}\text { Yield Stress, } \\
\text { Pa }\end{array}$ & $\begin{array}{c}\text { Consistency, } \\
\text { cP }\end{array}$ & $\begin{array}{c}\text { Total Solids, } \\
\text { wt \% }\end{array}$ & $\begin{array}{c}\text { Insoluble Solids, } \\
\text { wt \% }\end{array}$ \\
\hline SB10-1 & 97 & 2.60 & 10.22 & 27.87 & 15.69 \\
\hline SB10-2 & 150 & 0.34 & 5.21 & 25.29 & 11.99 \\
\hline SB10-3 & 103 & 8.65 & 3.47 & 26.98 & 15.25 \\
\hline SB10-5 & 100 & 7.89 & 33.42 & 27.18 & 15.57 \\
\hline SB10-7 & 100 & 10.52 & 25.16 & 27.63 & 16.79 \\
\hline SB10-8 & 150 & 1.59 & 8.48 & 26.49 & 15.46 \\
\hline SB10-9 & 150 & 0.56 & 5.85 & 26.82 & 13.31 \\
\hline
\end{tabular}

\subsection{SME Cycle Results}

The seven SME cycles were performed immediately following the SRAT cycle and utilized the estimated amount of frit based on the initial sludge additions and the expected amount of SRAT samples. The SME cycles did not include the addition of water simulating decon water additions but all included two frit slurry additions. As stated earlier, the SME cycle targeted a final solids concentration of $50 \mathrm{wt} \%$ total solids. $^{18}$

\subsubsection{SME Cycle Processing Observations}

Only hydrogen generation was noted as a potential processing issue during the SME cycle. The hydrogen generation in the highest acid run with the SB10-A simulant (no coal) exceeded the DWPF hydrogen limit during the final dewater at the completion of the SME cycle. Mixing was not an issue during processing. Mixer speed was maintained at 250 RPM throughout each run.

As shown in Figure 3-8, the $\mathrm{pH}$ profile of each SME cycle followed a similar profile with a dip in $\mathrm{pH}$ as the frit is added due to the formic acid content of the frit slurry followed by a gradual rise in $\mathrm{pH}$ as the slurry mix is concentrated. 


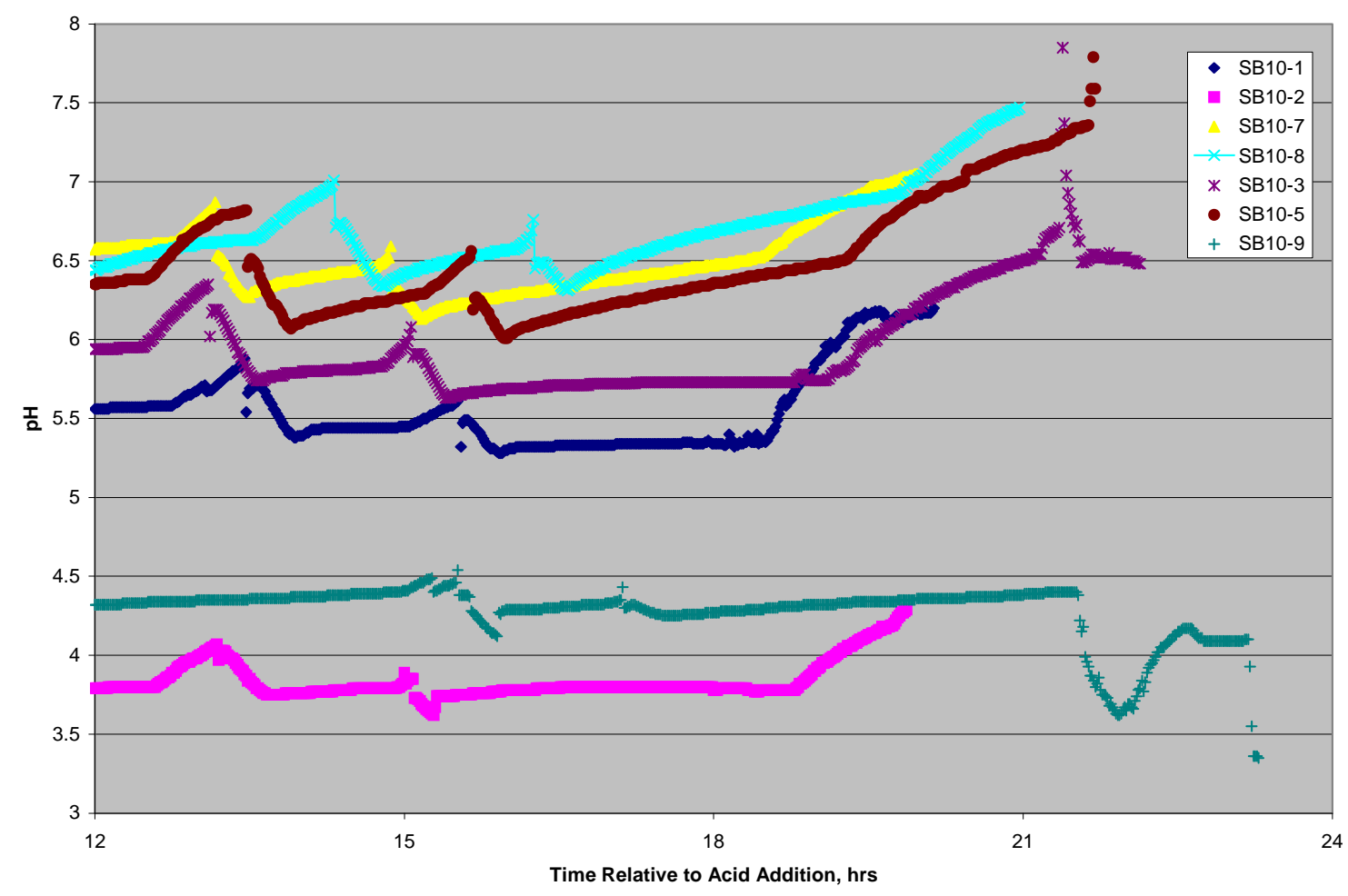

Figure 3-7. SME pH Profile

\subsubsection{SME Cycle Sample Results}

Samples were pulled at the conclusion of the SME cycle and analyzed for total solids, anions, soluble elemental species, and mercury. Samples were also taken of the composite SME dewater and the FAVC contents at the completion of the SME cycle.

\subsubsection{SME Cycle Waste Loading}

The lithium oxide content of the SME products is shown in Table 3-20 along with the calculated waste loading. The solids contents generally were higher than targeted, and the waste loading targets were slightly higher than the $38 \%$ target. Waste loadings were calculated from the PSAL analyzed lithium content of the SME product (the frit 418 was $7.42 \% \mathrm{Li}$ ). The waste loadings were within $2 \%$ of the planned targets. 
Table 3-20 SME Product Lithium Oxide Concentration and Waste Loading Results

\begin{tabular}{|c|c|c|}
\hline Run & $\begin{array}{c}\text { Lithium Oxide Content (wt \% } \\
\text { Calcined solids) }\end{array}$ & $\begin{array}{c}\text { Waste Loading, } \\
\text { Wt \% }\end{array}$ \\
\hline SB10-1 & 4.55 & 38.7 \\
\hline SB10-2 & 4.52 & 37.5 \\
\hline SB10-3 & 4.60 & 38.0 \\
\hline SB10-5 & 4.51 & 39.2 \\
\hline SB10-7 & 4.46 & 39.8 \\
\hline SB10-8 & 4.53 & 38.9 \\
\hline SB10-9 & 4.54 & 38.8 \\
\hline
\end{tabular}

\subsubsection{SME Cycle Anion Concentrations and Anion Conversion Results}

The SME products anion results are shown in Table 3-21. Loss of formate varied during the SME cycles, as shown in Table 3-22. The range of values noted during the testing is similar to results from previous runs.

Table 3-21 SME Product Anion Results, mg/kg slurry

\begin{tabular}{|c|c|c|c|c|c|c|c|c|}
\hline $\begin{array}{c}\text { Run ID \& Acid } \\
\text { Stoichiometry }\end{array}$ & $\mathbf{F}$ & $\mathbf{C l}$ & $\mathbf{N O}_{\mathbf{2}}$ & $\mathbf{N O}_{3}$ & $\mathbf{S O}_{\mathbf{4}}$ & $\mathbf{P O}_{\mathbf{4}}$ & $\mathbf{H C O}_{\mathbf{2}}$ & $\mathbf{C}_{\mathbf{2}} \mathbf{O}_{\mathbf{4}}{ }^{2-}$ \\
\hline SB10-1 97\% & $<100$ & 348 & $<100$ & 78,650 & $<100$ & $<100$ & 13,100 & $<100$ \\
\hline SB10-2 150\% & $<100$ & 307 & $<100$ & 76,300 & $<100$ & $<100$ & 24,850 & $<100$ \\
\hline SB10-3 103\% & $<100$ & 389 & $<100$ & 67,900 & $<100$ & $<100$ & 22,800 & $<100$ \\
\hline SB10-5 100\% & $<100$ & 298 & $<100$ & 41,650 & $<100$ & $<100$ & 40,100 & $<100$ \\
\hline SB10-7 100\% & $<100$ & 276 & $<100$ & 20,600 & $<100$ & $<100$ & 55,350 & $<100$ \\
\hline SB10-8 100\% & $<100$ & 286 & $<100$ & 17,850 & $<100$ & $<100$ & 52,400 & $<100$ \\
\hline SB10-9 150\% & $<100$ & 320 & $<100$ & 61,950 & $<100$ & $<100$ & 36,200 & $<100$ \\
\hline
\end{tabular}

Table 3-22 SME Product Anion Conversions (\%)

\begin{tabular}{|l|c|c|c|c|}
\hline \multirow{2}{*}{ Run ID } & \multicolumn{2}{|c|}{ Formate Destruction } & \multicolumn{2}{c|}{ Nitrate Destruction } \\
\cline { 2 - 5 } & Planned & Actual & Planned & Actual \\
\hline SB10-1 & 5 & 21.0 & 5 & -3.8 \\
\hline SB10-2 & 5 & 24.9 & 5 & 5.6 \\
\hline SB10-3 & 5 & 2.2 & 5 & 0.9 \\
\hline SB10-5 & 5 & 8.5 & 5 & 6.6 \\
\hline SB10-7 & 5 & 19.7 & 5 & 7.2 \\
\hline SB10-8 & 5 & 30.9 & 5 & 14.3 \\
\hline SB10-9 & 5 & 24.5 & 5 & 11.3 \\
\hline
\end{tabular}




\subsubsection{SME Cycle Carbon Sample Results}

The measurement of the carbon content of the SME product is the key to predicting the glass REDOX. REDOX is important since a melter feed with an oxidizing REDOX melts slower and a melter feed with a reducing REDOX may shorten melter life as the reduction of $\mathrm{Ni}, \mathrm{Cu}$ and noble metals to their elemental state have the potential to short the melter. Of key importance in this analysis is the determination of the nitrite, nitrate, formate, oxalate, and coal-carbon concentration of the SME product. The SME product anions were summarized in Table 3-21.

No reliable carbon data was available for the starting sludge with coal (SB10-B), SRAT products or SME products. As a result of this, coal-carbon estimates were used in all calculations throughout this report based on the coal-carbon measurement of the PDT sample. No estimates can be made of any possible decomposition of the coal during SRAT and SME processing. It is recommended that a coal-carbon method be developed for sludge, SRAT products and SME products.

Estimates of the carbon concentration were performed using two different methods. The first method used an $\mathrm{AD}$ carbon analyzer to measure the $\mathrm{CO}_{2}$ produced when heating the sample to $900^{\circ} \mathrm{C}$ (total carbon or TC) and to add acid to the sample to measure the $\mathrm{CO}_{2}$ evolved from the carbonate present (TIC). The TOC is calculated by subtracting TIC from TC. The TOC value includes all organic forms of carbon including oxalate and formate. To determine the coal-carbon concentration, the carbon in the oxalate and formate must be subtracted from the TOC. The second method was a thermal method to determine the coal-carbon concentration. This method dries the sample at $110^{\circ} \mathrm{C}{ }^{\circ}$ for $>2$ hours. Approximately $5 \mathrm{~g}$ of dried solids are added to $500 \mathrm{ml}$ of water. The slurry is filtered to remove soluble carbonate, formate and oxalate from the dried solids. Lastly, the solids are put in a $525{ }^{\circ} \mathrm{C}{ }^{\circ}$ furnace for two days to oxidize the coal-carbon to $\mathrm{CO}_{2}$. The coal-carbon concentration is estimated by measuring the mass loss at $525^{\circ} \mathrm{C}$.

The $\mathrm{AD}$ method is specific for carbon since it measures $\mathrm{CO}_{2}$. The Ion Chromatography (IC) anion analysis is another technique specific for the other forms of organic carbon (formate, oxalate) that are present in the SME products. Thus the coal-carbon estimate is expected to be an accurate measurement. However, the thermal method is not specific for coal-carbon. A number of other reactions can occur including anion decomposition and loss of waters of hydration so this method may overestimate the coal-carbon concentration. For example, the two sludges were each analyzed by this method. The mass loss of the SB10-B sludge simulant was $15.21 \%$ and the mass loss of the SB10-A sludge simulant (no coal) had a mass loss of $10.61 \%$.

Due to analytical difficulties, no reliable carbon data was available at the time this report was issued. As a result of this, coal-carbon estimates were used in all calculations throughout this report based on the coal-carbon measurement of the PDT sample.

\subsubsection{SME Sample Solids, Density and pH Results}

The SME Product solids, density and $\mathrm{pH}$ results are summarized in Table 3-23. The experiments with the highest $\mathrm{pH}$ were the two experiments without coal. The general trend in these experiments is that the more nitric acid added (less formic acid), the lower the final $\mathrm{pH}$. 
Table 3-23 SME Product Slurry Solids, Density and pH

\begin{tabular}{|l|c|c|c|c|c|c|c|}
\hline Run ID & $\begin{array}{c}\text { Total } \\
\text { Solids } \\
\text { wt \% }\end{array}$ & $\begin{array}{c}\text { Insoluble } \\
\text { Solids } \\
\text { wt \% }\end{array}$ & $\begin{array}{c}\text { Calcined } \\
\text { Solids } \\
\text { wt \% }\end{array}$ & $\begin{array}{c}\text { Supernate } \\
\text { Solids } \\
\text { wt \% }\end{array}$ & $\begin{array}{c}\text { Soluble } \\
\text { Solids } \\
\text { wt \% }\end{array}$ & $\begin{array}{c}\text { Density } \\
\text { g/mL }\end{array}$ & pH \\
\hline SB10-1 & 52.56 & 40.50 & 42.28 & 20.27 & $12.06 \%$ & 1.480 & 6.38 \\
\hline SB10-2 & 50.53 & 37.44 & 40.09 & 20.93 & $13.10 \%$ & 1.435 & 4.44 \\
\hline SB10-3 & 54.39 & 42.06 & 44.76 & 21.28 & $12.33 \%$ & 1.510 & 6.68 \\
\hline SB10-5 & 53.85 & 41.66 & 45.74 & 20.89 & $12.19 \%$ & 1.504 & 7.33 \\
\hline SB10-7 & 53.33 & 42.73 & 45.56 & 18.50 & $10.59 \%$ & 1.495 & 7.68 \\
\hline SB10-8 & 54.34 & 45.03 & 46.62 & 16.93 & $9.30 \%$ & 1.508 & 8.19 \\
\hline SB10-9 & 53.50 & 40.75 & 42.83 & 21.53 & $12.76 \%$ & 1.466 & 5.42 \\
\hline
\end{tabular}

\subsubsection{SME Slurry and Filtrate Sample ICP-AES Results and Calculated Percent Soluble}

The slurry elemental results from ICP-AES analyses are summarized in Table 3-24, the filtrate elemental results from ICP-AES analyses are summarized in Table 3-25, and the fraction of each element that is soluble is summarized in Table 3-26. In runs SB10-2 and SB10-9, both high acid runs with coal, iron and nickel are moderately soluble compared to being insoluble in the rest of the experiments. Note that the fraction of elements that are soluble decreased during the SME cycle. For example, the iron solubility dropped from $9.0 \%$ in the SB10-2 post SRAT sample to $1.33 \%$ in the SB10-2 post SME sample. 
Table 3-24 SME ICP-AES Slurry Results, wt \% Calcined Solids Basis

\begin{tabular}{|c|c|c|c|c|c|c|c|}
\hline Element & SB10-1 & SB10-2 & SB10-3 & SB10-5 & SB10-7 & SB10-8 & SB10-9 \\
\hline $\mathrm{Al}$ & 2.15 & 2.11 & 2.44 & 2.72 & 3.04 & 3.03 & 2.62 \\
\hline $\mathrm{B}$ & 1.35 & 1.37 & 1.35 & 1.32 & 1.32 & 1.32 & 1.32 \\
\hline $\mathrm{Ba}$ & 0.105 & 0.103 & 0.100 & 0.100 & 0.101 & 0.098 & 0.091 \\
\hline $\mathrm{Ca}$ & 1.20 & 1.17 & 1.14 & 1.11 & 1.07 & 1.09 & 1.01 \\
\hline $\mathrm{Cr}$ & 0.0682 & 0.0713 & 0.0694 & 0.0707 & 0.0750 & 0.0733 & 0.0644 \\
\hline $\mathrm{Fe}$ & 12.7 & 12.5 & 12.1 & 12.1 & 12.4 & 12.1 & 10.7 \\
\hline $\mathrm{K}$ & 0.168 & 0.165 & 0.170 & 0.121 & 0.105 & 0.122 & 0.128 \\
\hline $\mathrm{Li}$ & 2.12 & 2.13 & 2.14 & 2.10 & 2.08 & 2.11 & 2.11 \\
\hline $\mathrm{Mg}$ & 0.169 & 0.165 & 0.160 & 0.163 & 0.164 & 0.158 & 0.194 \\
\hline $\mathrm{Mn}$ & 1.96 & 1.99 & 1.88 & 1.92 & 1.97 & 1.88 & 1.74 \\
\hline $\mathrm{Na}$ & 8.87 & 8.78 & 8.91 & 9.09 & 9.22 & 8.91 & 9.72 \\
\hline $\mathrm{Ni}$ & 0.324 & 0.326 & 0.348 & 0.342 & 0.353 & 0.363 & 0.294 \\
\hline $\mathrm{Pb}$ & 0.164 & 0.162 & 0.157 & 0.162 & 0.168 & 0.158 & 0.140 \\
\hline $\mathrm{S}$ & 0.0309 & 0.0280 & 0.0266 & 0.0263 & 0.0226 & 0.0318 & 0.0643 \\
\hline $\mathrm{Si}$ & 24.18 & 24.09 & 24.00 & 23.87 & 23.48 & 23.62 & 23.76 \\
\hline $\mathrm{Ti}$ & 0.102 & 0.100 & 0.076 & 0.058 & 0.036 & 0.041 & 1.183 \\
\hline $\mathrm{Zn}$ & 0.0347 & 0.0317 & 0.0298 & 0.0290 & 0.0299 & 0.0301 & 0.0320 \\
\hline $\mathrm{Zr}$ & 0.299 & 0.294 & 0.285 & 0.295 & 0.285 & 0.285 & 0.268 \\
\hline
\end{tabular}


Table 3-25 SME Product ICP-AES Filtrate Results, mg/L

\begin{tabular}{|c|c|c|c|c|c|c|c|}
\hline Element & SB10-1 & SB10-2 & SB10-3 & SB10-4 & SB10-5 & SB10-6 & SB10-7 \\
\hline $\mathrm{Ag}$ & $<0.100$ & $<0.100$ & $<0.100$ & $<0.100$ & $<0.100$ & $<0.100$ & $<0.100$ \\
\hline $\mathrm{Al}$ & $<1.00$ & 3.87 & $<1.00$ & $<1.00$ & $<1.00$ & $<1.00$ & 7.82 \\
\hline B & 10.7 & 76.7 & 9.5 & 5.5 & 13.6 & 5.4 & 66.4 \\
\hline $\mathrm{Ba}$ & 65.9 & 112.1 & 44.8 & 15.3 & 8.5 & 8.9 & 0.9 \\
\hline $\mathrm{Ca}$ & 8220 & 7935 & 8265 & 6850 & 6675 & 3770 & 5250 \\
\hline $\mathrm{Cd}$ & $<0.100$ & $<0.100$ & $<0.100$ & $<0.100$ & $<0.100$ & $<0.100$ & $<0.100$ \\
\hline $\mathrm{Cr}$ & $<1.00$ & $<1.00$ & $<1.00$ & $<1.00$ & $<1.00$ & $<1.00$ & $<1.00$ \\
\hline $\mathrm{Fe}$ & $<1.00$ & 1170 & $<1.00$ & $<1.00$ & $<1.00$ & $<1.00$ & 2.72 \\
\hline K & 1155 & 984 & 1275 & 1015 & 936 & 995 & 974 \\
\hline $\mathrm{Li}$ & 251 & 256 & 296 & 300 & 344 & 259 & 290 \\
\hline $\mathrm{Mg}$ & 781 & 866 & 827 & 676 & 720 & 393 & 985 \\
\hline $\mathrm{Mn}$ & 6810 & 11350 & 6105 & 2500 & 1675 & 202 & 7520 \\
\hline $\mathrm{Na}$ & 47700 & 40700 & 51150 & 53850 & 57100 & 57850 & 57450 \\
\hline $\mathrm{Ni}$ & $<1.00$ & 536.35 & $<1.00$ & $<1.00$ & $<1.00$ & $<1.00$ & 179.82 \\
\hline $\mathrm{P}$ & $<10.0$ & $<10.0$ & $<10.0$ & $<10.0$ & $<10.0$ & $<10.0$ & $<10.0$ \\
\hline $\mathrm{Pb}$ & $<1.00$ & 3.37 & $<1.00$ & $<1.00$ & $<1.00$ & $<1.00$ & $<1.00$ \\
\hline $\mathrm{Pd}$ & $<1.00$ & $<1.00$ & $<1.00$ & $<1.00$ & $<1.00$ & $<1.00$ & $<1.00$ \\
\hline $\operatorname{Pr}$ & $<0.100$ & $<0.100$ & $<0.100$ & $<0.100$ & $<0.100$ & $<0.100$ & $<0.100$ \\
\hline $\mathrm{Rh}$ & $<1.00$ & $<1.00$ & $<1.00$ & $<1.00$ & $<1.00$ & 3.31 & $<1.00$ \\
\hline $\mathrm{Ru}$ & $<1.00$ & $<1.00$ & $<1.00$ & $<1.00$ & $<1.00$ & 11.44 & $<1.00$ \\
\hline $\mathrm{S}$ & 33.16 & 33.01 & 40.73 & 53.18 & 66.07 & 54.15 & 547.95 \\
\hline $\mathrm{Si}$ & 83.85 & 87.29 & 43.21 & 34.61 & 21.06 & 54.41 & 120.58 \\
\hline $\mathrm{Ti}$ & $<0.100$ & $<0.100$ & $<0.100$ & $<0.100$ & $<0.100$ & $<0.100$ & $<0.100$ \\
\hline $\mathrm{Zn}$ & $<0.100$ & 7.18 & $<0.100$ & $<0.100$ & $<0.100$ & $<0.100$ & 3.66 \\
\hline $\mathrm{Zr}$ & $<0.100$ & $<0.100$ & $<0.100$ & $<0.100$ & $<0.100$ & $<0.100$ & $<0.100$ \\
\hline
\end{tabular}


Table 3-26 SME Product Percent of ICP-AES Elements Soluble

\begin{tabular}{|c|c|c|c|c|c|c|c|}
\hline Element & SB10-1 & SB10-2 & SB10-3 & SB10-5 & SB10-7 & SB10-8 & SB10-9 \\
\hline $\mathrm{Al}$ & LDL & $0.03 \%$ & LDL & LDL & LDL & LDL & $0.03 \%$ \\
\hline $\mathrm{B}$ & $0.10 \%$ & $0.79 \%$ & $0.08 \%$ & $0.05 \%$ & $0.11 \%$ & $0.04 \%$ & $0.63 \%$ \\
\hline $\mathrm{Ba}$ & $8.05 \%$ & $15.5 \%$ & $5.03 \%$ & $1.73 \%$ & $0.97 \%$ & $0.95 \%$ & $0.11 \%$ \\
\hline $\mathrm{Ca}$ & $87.5 \%$ & $96.3 \%$ & $81.0 \%$ & $67.9 \%$ & $66.8 \%$ & $36.5 \%$ & $61.8 \%$ \\
\hline $\mathrm{Fe}$ & LDL & $1.33 \%$ & LDL & LDL & LDL & LDL & $0.00 \%$ \\
\hline $\mathrm{K}$ & $88.3 \%$ & $84.7 \%$ & $89.6 \%$ & $71.4 \%$ & $62.9 \%$ & $88.3 \%$ & $117 \%$ \\
\hline $\mathrm{Li}$ & $1.51 \%$ & $1.71 \%$ & $1.65 \%$ & $1.64 \%$ & $1.84 \%$ & $1.33 \%$ & $1.76 \%$ \\
\hline $\mathrm{Mg}$ & $59.2 \%$ & $74.5 \%$ & $57.7 \%$ & $47.5 \%$ & $51.3 \%$ & $25.9 \%$ & $75.5 \%$ \\
\hline $\mathrm{Mn}$ & $44.5 \%$ & $81.0 \%$ & $36.7 \%$ & $14.6 \%$ & $10.2 \%$ & $1.13 \%$ & $48.1 \%$ \\
\hline $\mathrm{Na}$ & $68.8 \%$ & $65.8 \%$ & $67.8 \%$ & $71.1 \%$ & $73.2 \%$ & $68.2 \%$ & $78.4 \%$ \\
\hline $\mathrm{Ni}$ & LDL & $23.37 \%$ & LDL & LDL & LDL & LDL & $6.47 \%$ \\
\hline $\mathrm{P}$ & LDL & LDL & LDL & LDL & LDL & LDL & LDL \\
\hline $\mathrm{Pb}$ & LDL & $0.30 \%$ & LDL & LDL & LDL & LDL & LDL \\
\hline $\mathrm{S}$ & $13.8 \%$ & $16.8 \%$ & $15.6 \%$ & $22.1 \%$ & $28.4 \%$ & $22.1 \%$ & $311 \% \wedge$ \\
\hline $\mathrm{Si}$ & $0.04 \%$ & $0.05 \%$ & $0.02 \%$ & $0.02 \%$ & $0.01 \%$ & $0.02 \%$ & $0.06 \%$ \\
\hline $\mathrm{Ti}$ & LDL & LDL & LDL & LDL & LDL & LDL & LDL \\
\hline $\mathrm{Zn}$ & LDL & $3.24 \%$ & LDL & LDL & LDL & LDL & $1.54 \%$ \\
\hline
\end{tabular}

$\mathrm{LDL}=$ Below Lower Detection Limit

${ }^{\wedge}$ Supernate $\mathrm{S}$ was approximately $3 \mathrm{x}$ higher than slurry $\mathrm{S}$ or Slurry $\mathrm{S}$ from $\mathrm{SO}_{4}$.

\subsubsection{SME Slurry Rheological Results}

The rheological properties of each SME product were measured. Higher acid stoichiometry lowered the yield stress and consistency of the SME products. Most of the runs were outside the design basis limits for yield stress $(2.5$ to $15 \mathrm{~Pa})$ and consistency $(10 \text { to } 40 \mathrm{cP})^{19}$ as shown in Table 3-27. Note that all samples were higher than the $50 \mathrm{wt} \%$ total solids target which contributed to the high yield stress values. The high acid runs with coal (SB10-2 and SB10-9) had the lowest (and acceptable) yield stress values. The products with added coal had higher yield stress values, but also had slightly higher total solids measurements.

Table 3-27 SME Product Rheological Properties

\begin{tabular}{|c|c|c|c|c|c|}
\hline Run ID & $\begin{array}{c}\text { Acid } \\
\text { \% }\end{array}$ & $\begin{array}{c}\text { Yield Stress, } \\
\text { Pa }\end{array}$ & $\begin{array}{c}\text { Consistency, } \\
\text { cP }\end{array}$ & $\begin{array}{c}\text { Total Solids, } \\
\text { wt \% }\end{array}$ & $\begin{array}{c}\text { Insoluble Solids, } \\
\text { wt \% }\end{array}$ \\
\hline SB10-1 & 97 & 23.1 & 34.4 & 52.56 & 40.50 \\
\hline SB10-2 & 150 & 4.43 & 30.9 & 50.53 & 37.44 \\
\hline SB10-3 & 103 & 44.0 & 28.1 & 54.39 & 42.06 \\
\hline SB10-5 & 100 & 34.0 & 87.0 & 53.85 & 41.66 \\
\hline SB10-7 & 100 & 29.5 & 51.6 & 53.33 & 42.73 \\
\hline SB10-8 & 150 & 25.8 & 40.7 & 54.34 & 45.03 \\
\hline SB10-9 & 150 & 7.44 & 40.5 & 53.50 & 40.75 \\
\hline
\end{tabular}




\subsubsection{SME Cycle Offgas Composition Results}

The offgas stream was analyzed for nitrogen, oxygen, hydrogen, helium, nitrous oxide, carbon dioxide using a gas chromatograph. The amount of offgas generated during the runs generally increased as acid stoichiometry increased, as indicated by the helium concentration in the offgas since helium is added at a constant $0.5 \mathrm{wt} \%$ of the incoming air purge. A typical offgas concentration profile is shown in Figure 3-9. The patterns of offgas emissions noted during the runs were typical of offgas generation during the SME cycle with hydrogen and carbon dioxide emissions occurring during dewatering after each frit slurry (with formic) addition.

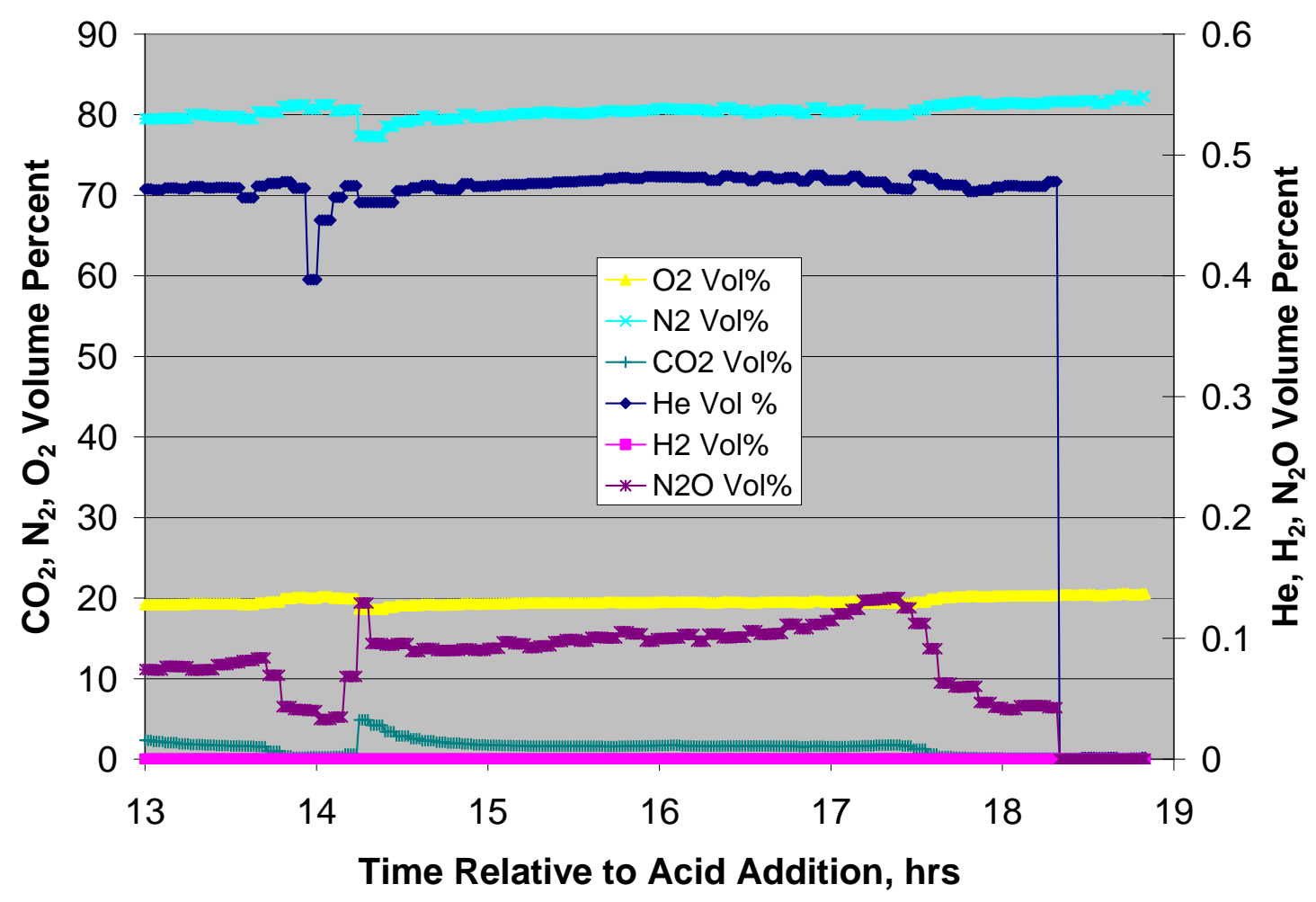

Figure 3-8. Typical SME Offgas Profile 100\% Acid Stoichiometry

\subsubsection{Hydrogen Evolution}

The peak hydrogen generation rates were generally noted as sharp spikes in the data immediately following the start of dewater, as shown in Figure 3-9. Peak generation rates scaled to the DWPF process are shown in Table 3-28 and were all below the SME process limit of $0.223 \mathrm{lb} / \mathrm{hr}$, except for the SB10-A (no coal) sludge at 150\% stoichiometry run (run SB10-8). This run exceeded the SME limit by $3.5 \mathrm{X}$. 
Table 3-28 SME Cycle Hydrogen Peak Generation Rate

\begin{tabular}{|c|c|c|c|}
\hline Run ID & $\begin{array}{c}\text { Sludge Predicted } \\
\text { Coal-carbon, mg/kg }\end{array}$ & $\begin{array}{c}\text { \% Acid } \\
\text { Stoichiometry }\end{array}$ & $\begin{array}{c}\text { Hydrogen } \\
\text { (lb/hr) }\end{array}$ \\
\hline SB10-1 & 19,800 & 97 & 0.0197 \\
\hline SB10-2 & 18,500 & 150 & 0.0215 \\
\hline SB10-3 & 12,900 & 103 & 0.0110 \\
\hline SB10-5 & 5,870 & 100 & 0.0010 \\
\hline SB10-7 & 0 & 100 & 0.0010 \\
\hline SB10-8 & 0 & 150 & 0.7915 \\
\hline SB10-9 & 10,000 & 150 & 0.0115 \\
\hline
\end{tabular}

\subsubsection{Other Species}

Carbon dioxide, as shown in Table 3-29, was generally the only other gas of any significance emitted during the SME cycle (the lower acid runs contained a small amount of nitrous oxide emissions)

Table 3-29 SME Cycle Nitrous Oxide and Carbon Dioxide Peak Generation Rates, lb/hr

\begin{tabular}{|c|c|c|c|c|}
\hline Run ID & $\begin{array}{c}\text { Sludge Predicted } \\
\text { Coal-carbon, mg/kg }\end{array}$ & $\begin{array}{c}\text { \% Acid } \\
\text { Stoichiometry }\end{array}$ & $\begin{array}{c}\mathbf{C O}_{\mathbf{2}} \text { Peak } \\
(\mathbf{l b} / \mathbf{h r} \mathbf{)}\end{array}$ & $\begin{array}{c}\mathbf{N}_{2} \mathbf{O} \text { Peak } \\
\mathbf{( l b / h r})\end{array}$ \\
\hline SB10-1 & 19,800 & 97 & 29.6 & 1.37 \\
\hline SB10-2 & 18,500 & 150 & 30.3 & 2.17 \\
\hline SB10-3 & 12,900 & 103 & 37.2 & 2.71 \\
\hline SB10-5 & 5,870 & 100 & 118.5 & 0.23 \\
\hline SB10-7 & 0 & 100 & 28.6 & 0.80 \\
\hline SB10-8 & 0 & 150 & 128.5 & 0.36 \\
\hline SB10-9 & 10,000 & 150 & 0.0 & 0.68 \\
\hline
\end{tabular}

\subsection{Glass Results}

Glass was produced from the SME products to allow the measurement of REDOX. In addition, the glass was sectioned and visually observed to look for crystals and reduced metals. Note that Frit 418 was used and no attempt was made to optimize the glass formulation. The glass shop noted that the glass was very hard compared to other glasses they have been sectioning.

\subsubsection{Glass REDOX Results}

The SME products were dried and melted using the REDOX Measurement Procedure. ${ }^{20}$ This method can produce overly oxidizing results (REDOX of 0 ) if the sample is overdried or the crucible seal is inadequate during melting. For example the two replicates might have a REDOX of 0.25 and 0.28 , while the third result is 0.00 . The procedure utilizes a nepheline gel seal which can be lost if excessive offgas is produced during melting (a problem with high acid stoichiometry runs, SB10-2, SB10-8, and SB10-9). In runs where the seal was obviously 
inadequate, no measure of the REDOX was performed. The measured and predicted REDOX results are summarized in Table 3-30. Note that the maximum REDOX result is reported as this might be the best REDOX measurement as problems with the seal during melting might lead to overly oxidized results.

Most of the REDOX results $\left(\mathrm{Fe}^{2+} / \Sigma \mathrm{Fe}\right)$ were within 0.1 of the predicted values. However, some of the values were higher than predicted and some were lower than predicted. A concern in using coal-carbon as a reductant is that the coal-carbon is such a good reductant that it can be difficult to control. It is similar to a $\mathrm{pH}$ titration curve where a small amount of acid near $\mathrm{pH} 7$ can make a big change in $\mathrm{pH}$. Based on the results of this study, the REDOX can likely be controlled in processing sludge with added coal-carbon.

Table 3-30 SME Product REDOX Results, $\mathrm{Fe}^{2+} / \Sigma \mathrm{Fe}$

\begin{tabular}{|l|c|c|c|c|c|}
\hline Run ID & $\begin{array}{c}\text { Average } \\
\text { Measured } \\
\mathbf{F e}^{2+} / \Sigma \mathbf{F e}\end{array}$ & $\begin{array}{c}\text { Standard } \\
\text { Deviation }\end{array}$ & $\begin{array}{c}\text { \% Relative } \\
\text { Standard } \\
\text { Deviation }\end{array}$ & $\begin{array}{c}\text { Maximum } \\
\mathbf{F e}^{2+} / \Sigma \mathbf{F e}\end{array}$ & $\begin{array}{c}\text { Predicted } \\
\mathbf{F e}^{2+} / \Sigma \mathbf{F e}\end{array}$ \\
\hline SB10-1 & 0.300 & 0.082 & 27.4 & 0.373 & 0.310 \\
\hline SB10-2 & 0.208 & 0.049 & 23.5 & 0.268 & 0.318 \\
\hline SB10-3 & $0.225^{*}$ & 0.117 & 52.0 & 0.328 & 0.124 \\
\hline SB10-5 & 0.235 & 0.147 & 62.4 & 0.352 & 0.178 \\
\hline SB10-7 & 0.237 & 0.039 & 16.4 & 0.288 & 0.225 \\
\hline SB10-8 & $0.218 \#$ & 0.002 & 0.9 & 0.219 & 0.251 \\
\hline SB10-9 & $0.332 \#$ & 0.002 & 0.5 & 0.333 & 0.113 \\
\hline
\end{tabular}

* Average of two glasses, not three as one was overly oxidized.

\# Only one glass was analyzed as the seal was lost during melting for the other two glasses.

\subsubsection{SME Product MAR Assessment of Sectioned Glass Samples}

A Measurement Acceptability Region (MAR) assessment approach for glass systems was developed by Peeler and Edwards to facilitate formulation of waste glasses for DWPF ${ }^{21}$. The MAR approach allows for efficient evaluation of glass compositions against the Product Composition Control System (PCCS) constraints developed for DWPF ${ }^{22}$ for various glass quality and processing properties. A MAR assessment was conducted for the compositions of the seven experiments in this study. The MAR assessment concluded that all of the MAR criteria were met for all seven experiments.

\subsection{DWPF Melter Processing Review}

A review was completed by SRNL concerning the processing of a melter feed containing the Tank 48 FBSR product in the DWPF melter. From a glass formulation and melter processing perspective, the introduction of the FSBR product into the DWPF flowsheet does require a review of the possible impacts to current operations. Jantzen ${ }^{23}$ indicates that the current flowsheet for Tank 48 FBSR processing produces a sodium carbonate based granular product that is $85-90 \mathrm{wt} \%$ soluble in water. The remaining 10-15 wt $\%$ are insolubles composed of (1) insoluble carbonates and sulfates such as $\mathrm{PbCO}_{3}$ and $\mathrm{BaSO}_{4}$, (2) alumina/bauxite bed material, (3) coal used to generate heat for autothermal processing, and (4) aluminosilicate containing coal ash and sodium aluminosilicates. From a glass formulation and melter processing perspective, the introduction of 
the FSBR product into the DWPF flowsheet does require a review of the possible impacts to current operations. Potential impacts or technical areas to assess include (but are not limited to):

(a) redox control primarily associated with the introduction of coal-carbon into the melter which, if not accounted for, could led to precipitation of metallic species within the melter or (if over compensated for) foaming within the melter,

(b) flammability concerns within the melter plenum again primarily due to the presence of coal-carbon in the incoming melter feed,

(c) the possibility of localized reduction within the glass pool from coal and the impact of precipitated phases (such as nickel sulfides on melter operation or materials of corrosion),

(d) the ability of frit development efforts to compensate for the FBSR secondary stream with respect to melter processing (e.g., viscosity, ability to attain waste loading requirements, melt rate, cold cap behavior, etc) and product performance (durability) constraints.

The potential impacts on the FBSR product on REDOX control (via modifications or changes to the acid addition strategy to ensure REDOX of the melter feed is maintained within acceptable limits) and melter flammability (through off-gas flammability calculations) are addressed in Section 3.7 of this report.

With respect to the ability of frit development efforts to accommodate the FBSR product, the current flowsheet has the FBSR product being added to Tank 51 followed by a washing strategy that ultimately establishes the same $\mathrm{Na}$ concentration (endpoint) as a flowsheet without the FBSR product. If this is the case, then the impact of $\mathrm{Na}_{2} \mathrm{O}$ from the FBSR product on glass formulation is not anticipated to be an issue.

The remaining issues that have been identified thus far are the potential impacts of the FSBR product on melt rate (for example, will the aluminate based products dissolve easily into the melt) and the potential for localized REDOX reductions assuming coal-carbon accumulation in the cold cap or within the glass pool. Given DWPF contractual agreements for canister production rates, the impact of the FBSR product on melt rate should be experimentally assessed. Historically, melt rate impacts have utilized a simulant SRAT product coupled with a candidate frit composition (targeting the anticipated waste loading). It is recommended that a slurry-fed, joule heated melter be utilized to assess the impact of the FBSR product on melt rate given the form of the FBSR product and potential processing impacts. A baseline flowsheet (specific sludge batch - frit system without the FBSR product) could be compared to the FBSR-based flowsheet (including acid additions strategy modifications to control REDOX) with respect to melt rate and other melter processing issues. Based on potential issues of localized reduction due to the presence of coal, one should consider the possible use of a melter platform that could allow for in-situ sampling or post-mortem (destructive) analysis to assess the potential for localized reduction, the formation of metallic precipitates, and/or possible interactions of reduced species (such as nickel sulfides) on materials of construction. To minimize programmatic risks, preliminary testing using small scale testing (crucibles and/or smaller melters) should be considered when technically feasible to address this latter issue. 


\subsection{DWPF Melter Off-Gas Flammability Assessment}

Melter off-gas flammability is determined largely by: (1) total organic carbon (TOC) in the feed, (2) feed rate, (3) air purges for combustion and cooling, (4) melter vapor space temperature, and (5) off-gas surge. In essence, all these variables are controlled either by the choice of flowsheet or by the mode of operation, and their impact on off-gas flammability is highly interdependent. For example, when TOC is increased at fixed air flows, the melter vapor space temperature would have to be increased in order to burn excess carbon. The melter vapor space temperature can be increased by reducing the feed rate, thereby exposing a greater area of melt surface for increased radiation shine into the vapor space. Reduced feed rate in turn not only reduces the rate of TOC fed to the melter but decreases the likelihood of off-gas surging as well. It is also to be noted that the degree of variability in TOC without counterbalancing changes in nitrate is limited since a proper balance between the reductant (carbon) and oxidant (nitrate) is required to ensure that the redox $\left(\mathrm{Fe}^{+2} / \Sigma \mathrm{Fe}\right)$ of the resulting glass remains within the acceptable range of 0.09-0.33.

Two computer models have been used to describe these complex interdependencies quantitatively and further set the operating limits of these variables in the form of feed interlocks and technical safety requirements (TSR). ${ }^{24,25}$ The first model, called the 4-stage cold cap model, describes the chemistry of cold cap reactions thermodynamically and predicts the compositions of both glass and calcine gases from a given feed chemistry. The composition of calcine gases thus calculated is used as the input to the second model, called the off-gas dynamics model, which predicts the transient behavior of the DWPF melter off-gas system, including the off-gas flammability, under various upset scenarios. The baseline upset scenario used in the off-gas flammability assessment for bubbled melter operation is the $9 \mathrm{X} / 5 \mathrm{X}$ off-gas surge, which is defined later in this section.

The following theoretical limits have been established for SB6 in order to ensure full compliance with the off-gas flammability safety bases for both normal and seismic melter operations: ${ }^{26}$

- $\quad$ TOC $\leq 18,900 \mathrm{ppm}$ (SME product).

- Melter Feed rate $\leq 1.5$ GPM

- Total melter air purge (FIC3221A) $\geq 900 \mathrm{lb} / \mathrm{hr}$ (nominally at $1,070 \mathrm{lb} / \mathrm{hr}$ )

- Backup film cooler air purge (FIC3221B) $\geq 233 \mathrm{lb} / \mathrm{hr}$ (nominally at $340 \mathrm{lb} / \mathrm{hr}$ )

- Melter vapor space temperature (TI4085D) $\geq 460{ }^{\circ} \mathrm{C}$.

It is noted that the actual TSR and feed interlock limits used in the field are set by applying appropriate analytical or instrument uncertainties to these theoretical limits.

Of those variables affecting off-gas flammability listed above, the focus of this assessment is on TOC, particularly the maximum amount of coal-carbon that can be fed to the DWPF melter without exceeding the off-gas flammability safety basis limits. Specifically, the potential for offgas flammability for all seven SB10 feed formulations that were tested during the bench-scale CPC demonstration was assessed in this study. In addition, if the calculated off-gas flammability for any of the feeds was below the safety basis limit of $60 \%$ of the lower flammability limit (LFL) for normal operation, additional coal was added to each "baseline" feed until the safety basis limit was reached. It is to be noted that coal-carbon was added without any redox considerations, i.e., without the addition of counterbalancing nitrate for redox control. These hypothetical feeds containing extra coal-carbon are termed the "max-coal" feeds in this study. 


\subsubsection{Flammability Assessment of Baseline Feeds}

\subsubsection{Cold Cap Model Input}

The input to the cold cap model was constructed by blending the SRAT products with Frit 418 at specified waste loadings to simulate the melter feed compositions. This required reconciling the SRAT product analytical data given in Table 3-10 to Table 3-16 until electroneutrality was achieved in the resulting slurries. Since the anion data particularly the formate has a direct impact on TOC and off-gas flammability, any charge imbalances were reconciled by adjusting the sodium data.

The results of charge balance are shown in Table 3-31. The sum of formate and nitrate accounted for practically $100 \%$ of the total anion charges in all SRAT products. The calculated charge imbalances were all quite large, except for SB10-1 and SB10-5, requiring significant adjustments in sodium concentration; for example, the reported sodium data for SB10-2 had to be reduced by $44.1 \%$ to achieve charge balance. It is noted that the SB10-2 SRAT product had the lowest $\mathrm{pH}$ at 3.85 and had the highest concentration of dissolved metals.

Table 3-31. Results of Charge Balance of SB10 SRAT Products.

\begin{tabular}{|c|c|c|c|c|c|c|c|c|}
\hline Run \# & $\begin{array}{c}\text { COOH } \\
\text { (ppm) }\end{array}$ & $\begin{array}{c}\text { NO3 } \\
\mathbf{( p p m )}\end{array}$ & $\begin{array}{c}\text { Total } \\
\text { Anion } \\
\text { (equiv } \\
\mathbf{M})\end{array}$ & $\begin{array}{c}\text { Na } \\
\mathbf{( M )}\end{array}$ & $\begin{array}{c}\text { Dissolved } \\
\text { Metals } \\
\text { (equiv } \\
\mathbf{M})\end{array}$ & $\begin{array}{c}\text { Total } \\
\text { Cation } \\
\text { (equiv } \\
\mathbf{M})\end{array}$ & $\begin{array}{c}\text { Cation- } \\
\text { Anion } \\
\text { (equiv } \\
\mathbf{M})\end{array}$ & $\begin{array}{c}\text { Charge } \\
\text { Imbalance } \\
\text { (\% Na) }\end{array}$ \\
\hline SB10-1 & 11,800 & 68,100 & 1.59 & 1.26 & 0.48 & 1.74 & 0.15 & 12.1 \\
\hline SB10-2 & 24,800 & 65,450 & 1.95 & 1.41 & 1.16 & 2.57 & 0.62 & 44.1 \\
\hline SB10-3 & 18,350 & 64,100 & 1.76 & 1.75 & 0.54 & 2.30 & 0.53 & 30.4 \\
\hline SB10-5 & 37,100 & 41,450 & 1.81 & 1.61 & 0.36 & 1.96 & 0.15 & 9.4 \\
\hline SB10-7 & 53,250 & 18,150 & 1.86 & 1.27 & 0.29 & 1.56 & -0.30 & -23.2 \\
\hline SB10-8 & 59,300 & 17,150 & 1.93 & 1.31 & 0.37 & 1.68 & -0.25 & -19.2 \\
\hline SB10-9 & 36,200 & 56,800 & 2.13 & 1.80 & 0.63 & 2.43 & 0.30 & 16.9 \\
\hline
\end{tabular}

Table 3-32 shows that $7.67 \%$ of the iron in SB10 was soluble at the $\mathrm{pH}$ of 3.85 and, as expected, its solubility fell to $1.25 \%$ at the $\mathrm{pH}$ of 4.61 in SB10-9, while iron remained essentially insoluble at higher $\mathrm{pH}$ 's. Since iron was by far the most abundant element in the SB10 feeds making up 25-30 wt $\%$ of the calcine solids (Table 3-14), its impact on the overall charge balance of SB10-2 was significant. The solubility of manganese also increased in general with decreasing $\mathrm{pH}$, while both calcium and magnesium remained quite soluble in the measured $\mathrm{pH}$ range. It is noted that the calculated solubilities in the charge-balanced slurries are somewhat lower than those given in Table 3-16 which are based on analytical data. 
Table 3-32. Varying Solubility of Major Metal Species with pH.

\begin{tabular}{|c|c|c|c|c|c|c|}
\hline Run \# & $\begin{array}{c}\text { Acid } \\
\text { Stoichiometry }\end{array}$ & $\mathbf{p H}$ & $\begin{array}{c}\text { Soluble Fe } \\
\text { (\% total } \\
\text { Fe) }\end{array}$ & $\begin{array}{c}\text { Soluble Ca } \\
\text { (\% total } \\
\text { Ca) }\end{array}$ & $\begin{array}{c}\text { Soluble } \\
\text { Mn } \\
\text { (\% total } \\
\text { Mn) }\end{array}$ & $\begin{array}{c}\text { Soluble Mg } \\
\text { (\% total } \\
\text { Mg) }\end{array}$ \\
\hline SB10-1 & $100 \%$ & 6.52 & 0.00 & 84.44 & 32.80 & 65.60 \\
\hline SB10-2 & $150 \%$ & 3.85 & 7.67 & 80.81 & 89.26 & 71.00 \\
\hline SB10-3 & $100 \%$ & 6.87 & 0.00 & 103.82 & 41.04 & 65.60 \\
\hline SB10-5 & $100 \%$ & 7.47 & 0.00 & 105.72 & 11.40 & 65.60 \\
\hline SB10-7 & $100 \%$ & 7.37 & 0.00 & 73.18 & 5.42 & 65.60 \\
\hline SB10-8 & $150 \%$ & 7.91 & 0.00 & 74.24 & 21.19 & 62.11 \\
\hline SB10-9 & $150 \%$ & 4.61 & 1.25 & 87.61 & 142.01 & 80.40 \\
\hline
\end{tabular}

The resulting charge-reconciled SB10 melter feed compositions are shown in Tables D-1 to D-7 in Appendix D. It is to be noted that the given feed component flows are set to give the current DWPF maximum feed rate of 1.5 GPM. Both SB10-7 and SB10-8 feeds did not contain any coal, while SB10-9 was the only feed that contained the ARP/MCU streams. The amount of coalcarbon in each feed was calculated based on the actual recipe given in Table 3-33, since available analytical results of coal-carbon were not conclusive.

Table 3-33. Recipe for Coal-carbon Addition to SB10 SRAT Product.

\begin{tabular}{|c|c|c|c|c|c|c|c|}
\hline & SB10-1 & SB10-2 & SB10-3 & SB10-5 & SB10-7 & SB10-8 & SB10-9 \\
\hline Coal added $($ gmol) & 3.467 & 3.517 & 2.403 & 1.203 & 0 & 0 & 1.940 \\
\hline SRAT Product $(\mathrm{g})$ & $2,124.55$ & $2,535.51$ & $2,244.60$ & $2,311.69$ & $2,696.96$ & $2,799.22$ & $2,570.92$ \\
\hline Density $(\mathrm{g} / \mathrm{ml})$ & 1.165 & 1.213 & 1.214 & 1.207 & 1.232 & 1.210 & 1.221 \\
\hline
\end{tabular}

The feed compositions given in Tables D-1 to D-7 were further decomposed into the final input form for the 4-stage cold cap model, as shown in Table 3-34 to Table 3-40. As described elsewhere $^{27}$ the model approximates the complex melting process as a continuous, 4-stage countercurrent equilibrium reactor, and the temperature of each stage is set progressively higher from the top (Stage 1) to bottom stage (Stage 4 ) at $1,150^{\circ} \mathrm{C}$. The non ideality that exists among various melt phases that form is partially accounted for in lower stages with the use of the Gibbs free energy database for the complex liquids, which was developed at the National Institute of Standards and Technology (NIST). ${ }^{27}$ In forming these model input vectors, all salts except sulfates were pre-decomposed into oxides and corresponding gases as follows:

$$
\begin{aligned}
& 2 \mathrm{Fe}(\mathrm{OH})_{3}=\mathrm{Fe}_{2} \mathrm{O}_{3}+3 \mathrm{H}_{2} \mathrm{O} \\
& 2 \mathrm{NaCOOH}=\mathrm{Na}_{2} \mathrm{C}_{2} \mathrm{O}_{4}+\mathrm{H}_{2} \\
& \mathrm{Na}_{2} \mathrm{C}_{2} \mathrm{O}_{4}=\mathrm{Na}_{2} \mathrm{O}+\mathrm{CO}+\mathrm{CO}_{2} \\
& 2 \mathrm{NaNO}_{3}=2 \mathrm{NaNO}_{2}+\mathrm{O}_{2}
\end{aligned}
$$




$$
2 \mathrm{NaNO}_{2}=\mathrm{Na}_{2} \mathrm{O}+\mathrm{NO}+\mathrm{NO}_{2}
$$

In particular, the decomposition of sodium nitrate is known to begin with the release of oxygen, thereby converting to nitrite at low temperatures, e.g., $\sim 350{ }^{\circ} \mathrm{C}$, and the subsequent decomposition of nitrite, which can take several different routes depending on the presence or absence of air and other gases, can persist beyond $850{ }^{\circ} \mathrm{C}$. Based on this ample experimental evidence, the model assumes that the decomposition of nitrite shown in Rxn. (6) occurs at 40:60 split between Stages 1 and 2, respectively. Coal-carbon was assumed to react over a wider temperature range, and the cold cap model input vectors reflect a 60:30:10 split of coal-carbon among Stages 1 to 3, respectively. It is also to be noted that the $\mathrm{H}_{2} \mathrm{O}$ shown in the model input vectors represent water produced from the decomposition reactions, e.g., Rxn. (2), not the free $\mathrm{H}_{2} \mathrm{O}$ that constituted $\sim 50 \mathrm{wt} \%$ of the slurry feed. Although SB10-9 contained $\mathrm{NaTi}_{2} \mathrm{O}_{5} \mathrm{H}$ as part of the MCU/ARP streams (Table B-7), one of its decomposition products, $\mathrm{TiO}_{2}$, was omitted from the cold cap model input vector (Table 3-40), since it is not known to affect glass redox or off-gas flammability.

Table 3-34. 4-Stage Cold Cap Model Input for SB10-1 at 1.5 GPM.

\begin{tabular}{|c|c|c|c|}
\hline Species & $\begin{array}{c}\text { Stage } 1 \\
\text { (gmole/hr) }\end{array}$ & $\begin{array}{c}\text { Stage } 2 \\
\text { (gmole/hr) }\end{array}$ & $\begin{array}{c}\text { Stage } 3 \\
\text { (gmole/hr) }\end{array}$ \\
\hline $\mathrm{Al} 2 \mathrm{O} 3$ & 0 & 82.086 & 0 \\
\hline B2O3 & 144.613 & 0 & 0 \\
\hline $\mathrm{CaO}$ & 0 & 61.955 & 0 \\
\hline $\mathrm{CuO}$ & 0.847 & 0 & 0 \\
\hline Fe2O3 & 240.815 & 0 & 0 \\
\hline $\mathrm{K} 2 \mathrm{O}$ & 2.866 & 0 & 0 \\
\hline $\mathrm{Li} 2 \mathrm{O}$ & 0 & 336.945 & 0 \\
\hline $\mathrm{MgO}$ & 0 & 0 & 13.647 \\
\hline $\mathrm{MnO} 2$ & 0 & 60.870 & 0 \\
\hline $\mathrm{MnO}$ & 29.708 & 0 & 0 \\
\hline $\mathrm{Na} 2 \mathrm{O}$ & 218.386 & 162.438 & 0 \\
\hline $\mathrm{NiO}$ & 12.218 & 0 & 0 \\
\hline $\mathrm{SiO} 2$ & 1689.056 & 0 & 0 \\
\hline $\mathrm{CaSO} 4$ & 0 & 0 & 0.460 \\
\hline $\mathrm{Na} 2 \mathrm{SO} 4$ & 0 & 0 & 0.210 \\
\hline Coal-Carbon & 450.330 & 225.165 & 75.055 \\
\hline $\mathrm{H} 2 \mathrm{O}$ & 519.322 & 0 & 0 \\
\hline $\mathrm{CO}$ & 0 & 60.248 & 0 \\
\hline $\mathrm{CO} 2$ & 0 & 60.248 & 0 \\
\hline $\mathrm{H} 2$ & 60.248 & 0 & 0 \\
\hline $\mathrm{O} 2$ & 100.946 & 151.420 & 0 \\
\hline $\mathrm{NO}$ & 100.946 & 151.420 & 0 \\
\hline $\mathrm{NO} 2$ & 100.946 & 151.420 & 0 \\
\hline
\end{tabular}


Table 3-35. 4-Stage Cold Cap Model Input for SB10-2 at 1.5 GPM.

\begin{tabular}{|c|c|c|c|}
\hline Species & $\begin{array}{c}\text { Stage } 1 \\
\text { (gmole/hr) }\end{array}$ & $\begin{array}{c}\text { Stage } 2 \\
\text { (gmole/hr) }\end{array}$ & $\begin{array}{c}\text { Stage } 3 \\
\text { (gmole/hr) }\end{array}$ \\
\hline $\mathrm{Al} 2 \mathrm{O} 3$ & 0 & 77.915 & 0 \\
\hline B2O3 & 137.676 & 0 & 0 \\
\hline $\mathrm{CaO}$ & 0 & 61.326 & 0 \\
\hline $\mathrm{CuO}$ & 0.645 & 0 & 0 \\
\hline $\mathrm{Fe} 2 \mathrm{O} 3$ & 232.706 & 0 & 0 \\
\hline $\mathrm{K} 2 \mathrm{O}$ & 2.565 & 0 & 0 \\
\hline $\mathrm{Li} 2 \mathrm{O}$ & 0 & 320.783 & 0 \\
\hline $\mathrm{MgO}$ & 0 & 0 & 13.993 \\
\hline $\mathrm{MnO} 2$ & 0 & 9.314 & 0 \\
\hline $\mathrm{MnO}$ & 77.372 & 0 & 0 \\
\hline $\mathrm{Na} 2 \mathrm{O}$ & 133.393 & 154.714 & 0 \\
\hline $\mathrm{NiO}$ & 12.331 & 0 & 0 \\
\hline $\mathrm{SiO} 2$ & 1609.128 & 0 & 0 \\
\hline $\mathrm{CaSO} 4$ & 0 & 0 & 0.481 \\
\hline $\mathrm{Na} 2 \mathrm{SO} 4$ & 0 & 0 & 0.235 \\
\hline Coal-Carbon & 343.559 & 171.779 & 57.260 \\
\hline $\mathrm{H} 2 \mathrm{O}$ & 480.058 & 0 & 0 \\
\hline $\mathrm{CO}$ & 0 & 113.649 & 0 \\
\hline $\mathrm{CO} 2$ & 0 & 113.605 & 0 \\
\hline $\mathrm{H} 2$ & 113.649 & 0 & 0 \\
\hline $\mathrm{O} 2$ & 97.778 & 146.667 & 0 \\
\hline $\mathrm{NO}$ & 87.067 & 130.601 & 0 \\
\hline $\mathrm{NO} 2$ & 87.067 & 130.601 & 0 \\
\hline
\end{tabular}

Table 3-36. 4-Stage Cold Cap Model Input for SB10-3 at 1.5 GPM.

\begin{tabular}{|c|c|c|c|}
\hline Species & $\begin{array}{c}\text { Stage } 1 \\
\text { (gmole/hr) }\end{array}$ & $\begin{array}{c}\text { Stage } 2 \\
\text { (gmole/hr) }\end{array}$ & $\begin{array}{c}\text { Stage } 3 \\
(\text { gmole/hr) }\end{array}$ \\
\hline $\mathrm{A} 12 \mathrm{O} 3$ & 0 & 109.860 & 0 \\
\hline $\mathrm{B} 2 \mathrm{O} 3$ & 156.444 & 0 & 0 \\
\hline $\mathrm{CaO}$ & 0 & 57.712 & 0 \\
\hline $\mathrm{CuO}$ & 0.000 & 0 & 0 \\
\hline $\mathrm{Fe} 2 \mathrm{O} 3$ & 288.567 & 0 & 0 \\
\hline $\mathrm{K} 2 \mathrm{O}$ & 3.715 & 0 & 0 \\
\hline $\mathrm{Li} 2 \mathrm{O}$ & 0 & 364.513 & 0 \\
\hline $\mathrm{MgO}$ & 0 & 0 & 14.162 \\
\hline $\mathrm{MnO} 2$ & 0 & 42.949 & 0 \\
\hline $\mathrm{MnO}$ & 29.898 & 0 & 0 \\
\hline $\mathrm{Na} 2 \mathrm{O}$ & 221.941 & 175.699 & 0 \\
\hline $\mathrm{NiO}$ & 13.194 & 0 & 0 \\
\hline $\mathrm{SiO} 2$ & 1724.607 & 0 & 0 \\
\hline $\mathrm{CaSO} 4$ & 0 & 0 & 0 \\
\hline $\mathrm{Na} 2 \mathrm{SO} 4$ & 0 & 0 & 0.260 \\
\hline Coal-Carbon & 286.884 & 143.442 & 47.814 \\
\hline $\mathrm{H} 2 \mathrm{O}$ & 643.299 & 0 & 0 \\
\hline $\mathrm{CO}$ & 0 & 90.980 & 0 \\
\hline $\mathrm{CO} 2$ & 0 & 90.951 & 0 \\
\hline $\mathrm{H} 2$ & 90.980 & 0 & 0 \\
\hline $\mathrm{O} 2$ & 92.268 & 138.402 & 0 \\
\hline $\mathrm{NO}$ & 92.268 & 138.402 & 0 \\
\hline $\mathrm{NO} 2$ & 92.268 & 138.402 & 0 \\
\hline
\end{tabular}


Table 3-37. 4-Stage Cold Cap Model Input for SB10-5 at 1.5 GPM.

\begin{tabular}{|c|c|c|c|}
\hline Species & $\begin{array}{c}\text { Stage } 1 \\
\text { (gmole/hr) }\end{array}$ & $\begin{array}{c}\text { Stage } 2 \\
\text { (gmole/hr) }\end{array}$ & $\begin{array}{c}\text { Stage } 3 \\
\text { (gmole/hr) }\end{array}$ \\
\hline $\mathrm{Al} 2 \mathrm{O} 3$ & 0 & 120.241 & 0 \\
\hline $\mathrm{B} 2 \mathrm{O} 3$ & 152.082 & 0 & 0 \\
\hline $\mathrm{CaO}$ & 0 & 53.617 & 0 \\
\hline $\mathrm{CuO}$ & 0.000 & 0 & 0 \\
\hline $\mathrm{Fe} 2 \mathrm{O} 3$ & 270.729 & 0 & 0 \\
\hline $\mathrm{K} 2 \mathrm{O}$ & 2.774 & 0 & 0 \\
\hline $\mathrm{Li} 2 \mathrm{O}$ & 0 & 354.349 & 0 \\
\hline $\mathrm{MgO}$ & 0 & 0 & 13.175 \\
\hline $\mathrm{MnO} 2$ & 0 & 63.150 & 0 \\
\hline $\mathrm{MnO}$ & 8.122 & 0 & 0 \\
\hline $\mathrm{Na} 2 \mathrm{O}$ & 291.946 & 170.519 & 0 \\
\hline $\mathrm{NiO}$ & 12.494 & 0 & 0 \\
\hline $\mathrm{SiO} 2$ & 1676.119 & 0 & 0 \\
\hline CaSO4 & 0 & 0 & 0 \\
\hline $\mathrm{Na} 2 \mathrm{SO} 4$ & 0 & 0 & 0.403 \\
\hline Coal-Carbon & 152.559 & 76.279 & 25.426 \\
\hline $\mathrm{H} 2 \mathrm{O}$ & 654.873 & 0 & 0 \\
\hline $\mathrm{CO}$ & 0 & 201.224 & 0 \\
\hline $\mathrm{CO} 2$ & 0 & 200.915 & 0 \\
\hline $\mathrm{H} 2$ & 201.224 & 0 & 0 \\
\hline $\mathrm{O} 2$ & 65.270 & 97.905 & 0 \\
\hline $\mathrm{NO}$ & 65.270 & 97.905 & 0 \\
\hline $\mathrm{NO} 2$ & 65.270 & 97.905 & 0 \\
\hline
\end{tabular}

Table 3-38. 4-Stage Cold Cap Model Input for SB10-7 at 1.5 GPM.

\begin{tabular}{|c|c|c|c|}
\hline Species & $\begin{array}{c}\text { Stage } 1 \\
\text { (gmole/hr) }\end{array}$ & $\begin{array}{c}\text { Stage } 2 \\
(\mathrm{gmole} / \mathrm{hr})\end{array}$ & $\begin{array}{c}\text { Stage } 3 \\
\text { (gmole/hr) }\end{array}$ \\
\hline $\mathrm{A} 12 \mathrm{O} 3$ & 0 & 119.431 & 0 \\
\hline $\mathrm{B} 2 \mathrm{O} 3$ & 151.519 & 0 & 0 \\
\hline $\mathrm{CaO}$ & 0 & 60.703 & 0 \\
\hline $\mathrm{CuO}$ & 0.872 & 0 & 0 \\
\hline $\mathrm{Fe} 2 \mathrm{O} 3$ & 236.813 & 0 & 0 \\
\hline $\mathrm{K} 2 \mathrm{O}$ & 1.889 & 0 & 0 \\
\hline $\mathrm{Li} 2 \mathrm{O}$ & 0 & 353.037 & 0 \\
\hline $\mathrm{MgO}$ & 0 & 0 & 13.293 \\
\hline $\mathrm{MnO} 2$ & 0 & 86.622 & 0 \\
\hline $\mathrm{MnO}$ & 4.966 & 0 & 0 \\
\hline $\mathrm{Na} 2 \mathrm{O}$ & 327.377 & 170.196 & 0 \\
\hline $\mathrm{NiO}$ & 11.952 & 0 & 0 \\
\hline $\mathrm{SiO} 2$ & 1734.112 & 0 & 0 \\
\hline $\mathrm{CaSO} 4$ & 0 & 0 & 0.112 \\
\hline $\mathrm{Na} 2 \mathrm{SO} 4$ & 0 & 0 & 0.492 \\
\hline Coal-Carbon & 0 & 0 & 0 \\
\hline $\mathrm{H} 2 \mathrm{O}$ & 634.246 & 0 & 0 \\
\hline $\mathrm{CO}$ & 0 & 304.482 & 0 \\
\hline $\mathrm{CO} 2$ & 0 & 304.482 & 0 \\
\hline $\mathrm{H} 2$ & 304.482 & 0 & 0 \\
\hline $\mathrm{O} 2$ & 30.131 & 45.196 & 0 \\
\hline $\mathrm{NO}$ & 33.073 & 49.609 & 0 \\
\hline $\mathrm{NO} 2$ & 33.073 & 49.609 & 0 \\
\hline
\end{tabular}


Table 3-39. 4-Stage Cold Cap Model Input for SB10-8 at 1.5 GPM.

\begin{tabular}{|c|c|c|c|}
\hline Species & $\begin{array}{c}\text { Stage } 1 \\
\text { (gmole/hr) }\end{array}$ & $\begin{array}{c}\text { Stage } 2 \\
\text { (gmole/hr) }\end{array}$ & $\begin{array}{c}\text { Stage } 3 \\
\text { (gmole/hr) }\end{array}$ \\
\hline $\mathrm{A} 12 \mathrm{O} 3$ & 0 & 121.208 & 0 \\
\hline $\mathrm{B} 2 \mathrm{O} 3$ & 158.555 & 0 & 0 \\
\hline $\mathrm{CaO}$ & 0 & 61.427 & 0 \\
\hline $\mathrm{CuO}$ & 0.000 & 0 & 0 \\
\hline $\mathrm{Fe} 2 \mathrm{O} 3$ & 238.503 & 0 & 0 \\
\hline $\mathrm{K} 2 \mathrm{O}$ & 1.923 & 0 & 0 \\
\hline $\mathrm{Li} 2 \mathrm{O}$ & 0 & 369.431 & 0 \\
\hline $\mathrm{MgO}$ & 0 & 0 & 15.462 \\
\hline $\mathrm{MnO} 2$ & 0 & 72.390 & 0 \\
\hline $\mathrm{MnO}$ & 19.460 & 0 & 0 \\
\hline $\mathrm{Na} 2 \mathrm{O}$ & 323.700 & 178.100 & 0 \\
\hline $\mathrm{NiO}$ & 13.445 & 0 & 0 \\
\hline $\mathrm{SiO} 2$ & 1813.407 & 0 & 0 \\
\hline CaSO4 & 0 & 0 & 0.470496 \\
\hline $\mathrm{Na} 2 \mathrm{SO} 4$ & 0 & 0 & 0.369 \\
\hline Coal-Carbon & 0 & 0 & 0 \\
\hline $\mathrm{H} 2 \mathrm{O}$ & 642.661 & 0 & 0 \\
\hline $\mathrm{CO}$ & 0 & 331.134 & 0 \\
\hline $\mathrm{CO} 2$ & 0 & 331.134 & 0 \\
\hline $\mathrm{H} 2$ & 331.134 & 0 & 0 \\
\hline $\mathrm{O} 2$ & 27.803 & 41.705 & 0 \\
\hline $\mathrm{NO}$ & 27.803 & 41.705 & 0 \\
\hline $\mathrm{NO} 2$ & 27.803 & 41.705 & 0 \\
\hline
\end{tabular}

Table 3-40. 4-Stage Cold Cap Model Input for SB10-9 at 1.5 GPM.

\begin{tabular}{|c|c|c|c|}
\hline Species & $\begin{array}{c}\text { Stage } 1 \\
\text { (gmole/hr) }\end{array}$ & $\begin{array}{c}\text { Stage } 2 \\
(\mathrm{gmole} / \mathrm{hr})\end{array}$ & $\begin{array}{c}\text { Stage } 3 \\
\text { (gmole/hr) }\end{array}$ \\
\hline $\mathrm{A} 12 \mathrm{O} 3$ & 0 & 106.149 & 0 \\
\hline $\mathrm{B} 2 \mathrm{O} 3$ & 145.157 & 0 & 0 \\
\hline $\mathrm{CaO}$ & 0 & 43.743 & 0 \\
\hline $\mathrm{CuO}$ & 0.000 & 0 & 0 \\
\hline $\mathrm{Fe} 2 \mathrm{O} 3$ & 222.765 & 0 & 0 \\
\hline $\mathrm{K} 2 \mathrm{O}$ & 2.521 & 0 & 0 \\
\hline $\mathrm{Li} 2 \mathrm{O}$ & 0 & 338.214 & 0 \\
\hline $\mathrm{MgO}$ & 0 & 0 & 15.005 \\
\hline $\mathrm{MnO} 2$ & 0 & 0.000 & 0 \\
\hline $\mathrm{MnO}$ & 56.703 & 0 & 0 \\
\hline $\mathrm{Na} 2 \mathrm{O}$ & 289.103 & 174.735 & 0 \\
\hline $\mathrm{NiO}$ & 10.243 & 0 & 0 \\
\hline $\mathrm{SiO} 2$ & 1604.011 & 0 & 0 \\
\hline $\mathrm{CaSO} 4$ & 0 & 0 & 6.191 \\
\hline $\mathrm{Na} 2 \mathrm{SO} 4$ & 0 & 0 & 3.080 \\
\hline Coal-Carbon & 218.234 & 109.117 & 36.372 \\
\hline $\mathrm{H} 2 \mathrm{O}$ & 569.411 & 0 & 0 \\
\hline $\mathrm{CO}$ & 0 & 193.703 & 0 \\
\hline $\mathrm{CO} 2$ & 0 & 193.798 & 0 \\
\hline $\mathrm{H} 2$ & 193.703 & 0 & 0 \\
\hline $\mathrm{O} 2$ & 89.908 & 134.863 & 0 \\
\hline $\mathrm{NO}$ & 88.236 & 132.354 & 0 \\
\hline $\mathrm{NO} 2$ & 88.236 & 132.354 & 0 \\
\hline
\end{tabular}




\subsubsection{Cold Cap Model Output}

The compositions of both calcine gases and glasses predicted by the cold cap model are shown in Table 3-41 and Table 3-42, respectively, for the seven SB10 cases considered. It is noted that the calculated TOC's were much higher than that of the SB6; the TOC's for SB10-1 and SB10-2 were even higher than the current DWPF TSR limit of $18,900 \mathrm{ppm}$. The molar ratios of $\mathrm{CO} / \mathrm{CO}_{2}$ and $\mathrm{H}_{2} /\left(\mathrm{CO}+\mathrm{CO}_{2}\right)$ represent the relative flammability of calcine gas flows, and they are expected to increase as TOC increases. However, no clear trend can be seen between those ratios and TOC in SB10 feeds, since the makeup of TOC and the counterbalancing nitrate level were all different from one feed to the next. It is interesting to note that both SB10-3 and SB10-9 calcine gases had no flammable components despite high TOC levels. These seemingly-counterintuitive results illustrate the fact that not only the TOC but the nitrate (oxidant) levels determine the flammability potential of each feed. Therefore, the TOC data must be taken in along with the corresponding nitrate data in order to provide an accurate measure of the flammability potential of each feed.

Table 3-41. Calculated Calcine Gas Compositions of Baseline Feeds at 1.5 GPM.

\begin{tabular}{|l|r|r|r|r|r|r|r|}
\hline & $\begin{array}{r}\text { SB10-1 } \\
\text { (gmole/hr) }\end{array}$ & $\begin{array}{r}\text { SB10-2 } \\
(\mathrm{gmole} / \mathrm{hr})\end{array}$ & $\begin{array}{r}\text { SB10-3 } \\
(\mathrm{gmole} / \mathrm{hr})\end{array}$ & $\begin{array}{r}\text { SB10-5 } \\
(\mathrm{gmole} / \mathrm{hr})\end{array}$ & $\begin{array}{r}\text { SB10-7 } \\
(\mathrm{gmole} / \mathrm{hr})\end{array}$ & $\begin{array}{r}\text { SB10-8 } \\
(\mathrm{gmole} / \mathrm{hr})\end{array}$ & $\begin{array}{r}\text { SB10-9 } \\
\text { (gmole/hr) }\end{array}$ \\
\hline $\mathrm{H}_{2} \mathrm{O}$ & 453.749 & 492.030 & 734.330 & 835.214 & 870.868 & 882.308 & 763.104 \\
\hline $\mathrm{CO}_{2}$ & 743.117 & 708.993 & 659.952 & 646.399 & 580.776 & 622.017 & 751.069 \\
\hline $\mathrm{H}_{2}$ & 125.799 & 101.674 & 0 & 20.806 & 67.894 & 91.473 & 0 \\
\hline $\mathrm{N}_{2}$ & 252.405 & 217.649 & 230.712 & 163.164 & 82.683 & 69.505 & 220.557 \\
\hline $\mathrm{CO}$ & 127.964 & 90.998 & 0 & 10.001 & 28.123 & 40.054 & 0 \\
\hline $\mathrm{O}_{2}$ & 0 & 0.000 & 40.987 & 0 & 0 & 0 & 7.312 \\
\hline $\mathrm{SO}_{2}$ & 0.014 & 0.016 & 0.011 & 0.009 & 0 & 0 & 0.014 \\
\hline $\mathrm{NO}$ & 0 & 0 & 0.006 & 0 & 0 & 0 & 0.003 \\
\hline $\mathrm{NO}_{2}$ & 0 & 0 & 0 & 0 & 0 & 0 & 0 \\
\hline $\mathrm{NaBO}_{2}$ & 0 & 0 & 0.001 & 0 & 0 & 0 & 0.001 \\
\hline $\mathrm{Total}^{2}$ & $1,703.049$ & 1611.360 & 1665.999 & 1675.594 & 1630.344 & 1705.357 & 1742.059 \\
\hline $\mathrm{CO} / \mathrm{CO}_{2}$ & 0.172 & 0.128 & 0 & 0.015 & 0.048 & 0.064 & 0 \\
\hline $\begin{array}{l}\mathrm{H}_{2} / \\
\left(\mathrm{CO}+\mathrm{CO}_{2}\right)\end{array}$ & 0.144 & 0.127 & 0 & 0.032 & 0.112 & 0.138 & 0 \\
\hline $\mathrm{TOC}(\mathrm{ppm})$ & 20,727 & 19,628 & 15,393 & 15,370 & 14,332 & 15,452 & 18,037 \\
\hline
\end{tabular}

This point is further illustrated in Table 3-41; the molar ratios of $\mathrm{CO} / \mathrm{CO}_{2}$ and $\mathrm{H}_{2} /\left(\mathrm{CO}+\mathrm{CO}_{2}\right)$ are generally low for their TOC, since all SB10 baseline feeds were redox-adjusted. By contrast, the existing method of determining the maximum TOC limit is by increasing the concentrations of all formate salts in the baseline feed by the same ratio without any redox considerations until the peak flammable gas concentration during the design basis off-gas surge equals the safety basis limits. As a result, the calculated REDOX of such a maximum-TOC feed would become much higher than that of the baseline feed, and the resulting calcine gases more flammable. This approach of increasing the formate level without the accompanying increase in nitrate level was originally used to simulate the situation where slugs of insoluble, high-boiling aromatic carbon species from the precipitate hydrolysis process enter the melter. Since the formate salts are highly 
SRNL-STI-2010-00589

Revision 0

Table 3-42. Calculated Glass Compositions of Baseline Feeds at 1.5 GPM.

\begin{tabular}{|c|c|c|c|c|c|c|c|}
\hline & $\begin{array}{r}\text { SB10-1 } \\
\text { (gmole/hr) } \\
\end{array}$ & $\begin{array}{r}\text { SB10-2 } \\
\text { (gmole/hr) } \\
\end{array}$ & $\begin{array}{r}\text { SB10-3 } \\
\text { (gmole/hr) } \\
\end{array}$ & $\begin{array}{r}\text { SB10-5 } \\
\text { (gmole/hr) } \\
\end{array}$ & $\begin{array}{r}\text { SB10-7 } \\
\text { (gmole/hr) } \\
\end{array}$ & $\begin{array}{r}\text { SB10-8 } \\
\text { (gmole/hr) } \\
\end{array}$ & $\begin{array}{r}\text { SB10-9 } \\
\text { (gmole/hr) } \\
\end{array}$ \\
\hline \multicolumn{8}{|l|}{ Melt Phase } \\
\hline $\mathrm{SiO}_{2} 1$ & $1,265.016$ & $1,279.120$ & $1,286.718$ & $1,178.336$ & $1,197.349$ & $1,249.091$ & $1,105.081$ \\
\hline $\mathrm{Na}_{2} \mathrm{SiO}_{3}$ & 381.051 & 288.283 & 397.946 & 462.828 & 498.093 & 502.163 & 466.910 \\
\hline $\mathrm{LiBO}_{2} 1$ & 288.824 & 275.084 & 312.440 & 303.650 & 302.663 & 316.643 & 289.950 \\
\hline $\mathrm{LiAlO}_{2} 1$ & 164.167 & 155.813 & 219.758 & 240.578 & 238.900 & 242.381 & 212.356 \\
\hline $\mathrm{Fe}_{3} \mathrm{O}_{4} \mathrm{l}$ & 116.925 & 90.086 & 76.324 & 41.870 & 92.334 & 121.127 & 58.769 \\
\hline $\mathrm{MgSiO}_{3} 1$ & 10.848 & 11.023 & 11.607 & 10.880 & 10.695 & 12.175 & 13.152 \\
\hline $\mathrm{FeO} 1$ & 25.174 & 19.396 & 16.433 & 9.015 & 19.880 & 58.364 & 12.653 \\
\hline $\mathrm{CaFe}_{2} \mathrm{O}_{4}$ & 14.562 & 13.590 & 14.138 & 13.609 & 15.132 & 7.603 & 11.502 \\
\hline $\mathrm{B}_{2} \mathrm{O}_{3} \mathrm{l}$ & $8.8 \mathrm{E}-05$ & $8.4 \mathrm{E}-05$ & $1.2 \mathrm{E}-04$ & $1.3 \mathrm{E}-04$ & $1.3 \mathrm{E}-04$ & $1.3 \mathrm{E}-04$ & $1.1 \mathrm{E}-04$ \\
\hline $\mathrm{Ca}_{2} \mathrm{SiO}_{4}$ & 19.550 & 19.427 & 17.943 & 16.468 & 18.770 & 21.796 & 11.925 \\
\hline $\mathrm{Ca}_{3} \mathrm{MgSi}_{2}{ }^{*}$ & 2.718 & 2.890 & 2.481 & 2.222 & 2.524 & 3.287 & 1.777 \\
\hline $\mathrm{Fe}_{2} \mathrm{SiO}_{4}$ & 4.551 & 3.082 & 1.888 & 0.563 & 2.512 & 19.975 & 1.124 \\
\hline $\mathrm{KBO}_{2}$ & 0.404 & 0.360 & 0.528 & 0.492 & 82.273 & 89.955 & 0.442 \\
\hline $\mathrm{Li}_{2} \mathrm{O} 1$ & 110.375 & 105.316 & 98.465 & 82.334 & 1.685 & 1.716 & 87.139 \\
\hline $\mathrm{K}_{2} \mathrm{SiO}_{3}$ & 2.664 & 2.385 & 3.449 & 2.528 & 0.408 & 0.416 & 2.300 \\
\hline \multicolumn{8}{|c|}{ Spinel Phase } \\
\hline $\mathrm{NiFe}_{2} \mathrm{O}_{4}$ & 12.218 & 12.332 & 13.185 & 12.502 & 11.951 & 0 & 10.243 \\
\hline $\mathrm{Mn}_{3} \mathrm{O}_{4}$ & 30.193 & 28.894 & 24.283 & 23.756 & 30.530 & 0 & 18.900 \\
\hline $\mathrm{CuFe}_{2} \mathrm{O}_{4}$ & 0.846 & 0.645 & 0 & 0 & 0.873 & 0 & 0 \\
\hline $\mathrm{MgFe}_{2} \mathrm{O}_{4}$ & 0.081 & 0.079 & 0.074 & 0.073 & 0.085 & 0 & 0.076 \\
\hline \multicolumn{8}{|l|}{ ICP } \\
\hline $\mathrm{Fe}_{2} \mathrm{O}_{3}$ & 20.560 & 58.070 & 136.563 & 176.617 & 57.776 & 0 & 105.310 \\
\hline $\mathrm{CaSO}_{4}$ & 0.657 & 0.702 & 0.244 & 0.396 & 0.604 & 0.417 & 9.255 \\
\hline $\mathrm{Ni}$ & 0 & 0 & 0 & 0 & 0 & 0 & 0 \\
\hline $\mathrm{NiO}$ & 0 & 0 & 0 & 0 & 0 & 13.444 & 0 \\
\hline $\mathrm{Ni}_{3} \mathrm{~S}_{2}$ & 0 & 0 & 0 & 0 & 0 & 0 & 0 \\
\hline $\mathrm{Cu}$ & 0 & 0 & 0 & 0 & 0 & 0 & 0 \\
\hline $\mathrm{MnO}$ & 0 & 0 & 0 & 0 & 0 & 91.847 & 0 \\
\hline \multicolumn{8}{|c|}{$\operatorname{Redox}\left(\mathrm{Fe}^{+2} / \mathrm{Fe}^{\text {total }}\right)$} \\
\hline Calculated & 0.314 & 0.249 & 0.167 & 0.096 & 0.248 & 0.460 & 0.165 \\
\hline Predicted & 0.326 & 0.285 & 0.109 & 0.182 & 0.232 & 0.291 & 0.148 \\
\hline Measured & 0.300 & 0.208 & 0.225 & 0.235 & 0.237 & 0.218 & 0.332 \\
\hline TOC (ppm) & 20,727 & 19,628 & 15,393 & 15,370 & 14,332 & 15,452 & 18,037 \\
\hline
\end{tabular}

* The melt species $\mathrm{Ca}_{3} \mathrm{MgSi}_{2}$ is a truncated name for $\mathrm{Ca}_{3} \mathrm{MgSi}_{2} \mathrm{O}_{8}$ or $3 \mathrm{CaO} \cdot \mathrm{MgO} .2 \mathrm{SiO}_{2}$. 
soluble in aqueous solutions, applying the same approach to the formate carbon would make the resulting TOC limit conservative. However, the selective increase in reductant level without the accompanying increase in oxidant level seems more justified for coal-carbon, since it is insoluble and its wide particle size distribution makes its segregation in the slurry more likely. Therefore, the scenario of slugs of coal-carbon entering the melter is plausible.

The predicted SB10 glass oxides are split into groups or phases in Table 3-42. The letter I after each species in the melt phase denotes "liquid." These liquid or melt species were taken from the NIST database $;^{30}$ they do not necessarily represent independent molecular or ionic species but serve to represent the local associative order. Due to structural similarities, the spinels readily form solid solutions with one another and thus are assumed to form a separate phase of their own. On the other hand, each species included in the Invariant Condensed Phase (ICP) is assumed to form a separate phase by itself. Therefore, as more species are included in the ICP, the total number of phases to be considered in the equilibrium calculations increases, and this makes it more difficult to achieve convergence. It is noted that at the calculated redox of 0.46 for SB10-8 the glass was reducing enough to form no hematite and all manganese was in a +2 oxidation state as in $\mathrm{MnO}$, rather than in a hybrid of $+2(33 \%)$ and $+3(67 \%)$ oxidation states as in Hausmannite $\left(\mathrm{Mn}_{3} \mathrm{O}_{4}\right)$. Furthermore, at the redox ratio of 0.46 , nickel is predicted to precipitate as NiO instead of forming a multiple oxide with iron as $\mathrm{NiO} . \mathrm{Fe}_{2} \mathrm{O}_{3}$ as part of the spinel phase.

The calculated redox ratios using the cold cap model are next plotted in Figure 3-9 against the net reducing potential, which is defined as $\mathrm{F}-3 \mathrm{~N}+2 \mathrm{C}$ where $\mathrm{F}, \mathrm{N}$ and $\mathrm{C}$ are molar concentrations of formate, nitrate and coal-carbon, respectively. Also plotted are the redox ratios predicted from Eq. (1) along with measured data. As expected, both the calculated and predicted redox ratios increase with increasing net reducing potential, and the exponential functions that best fit each data set are quite similar until they begin to diverge at $(\mathrm{F}-3 \mathrm{~N}+2 \mathrm{C})>\sim 0.35$. On the other hand, the measured redox ratios remained more or less flat, showing no dependence on the net reducing potential.

\subsubsection{Off-Gas Dynamics Model Input}

The calculated calcine gas compositions given in Table 3-41 were next used as the input to the off-gas dynamics model in order to check if the off-gas flammability safety basis limit of $60 \%$ of the LFL for normal operation is exceeded during a design basis off-gas surge. Briefly, the model predicts the time-dependent responses of both the primary and backup DWPF melter off-gas systems under a variety of upset conditions. ${ }^{25}$ It calculates 5-component mass and energy balances for the condensable and non-condensable gases from first principles. It simulates all major DWPF melter off-gas system hardware, including 22 Proportional-Integral (PI) controllers and 26 valves, and the Distributed Control System (DCS) software logic to provide protection against extreme pressure transients and other operational anomalies such as equipment malfunction. It employs a 2-step global reaction scheme using the empirical first-order oxidation kinetics of $\mathrm{CO}$ and $\mathrm{H}_{2}$ to model combustion of calcine gases in the melter vapor space.

The design basis $9 \mathrm{X} / 5 \mathrm{X}$ off-gas surge for bubbled melter operation is assumed to proceed as follows: ${ }^{26}$

- At time zero, the baseline flow rates of steam and non-condensable gases increase 9- and 5-fold, respectively, instantly and then immediately start to decrease linearly to 3.5 times (3.5X) and 2 times $(2 \mathrm{X})$ the normal condensable and non-condensable flows during the first 1 minute.

- The flow rates of both steam and non-condensable gases further decrease linearly to the normal values (1X) during the next 7 minutes. 
SRNL-STI-2010-00589

Revision 0

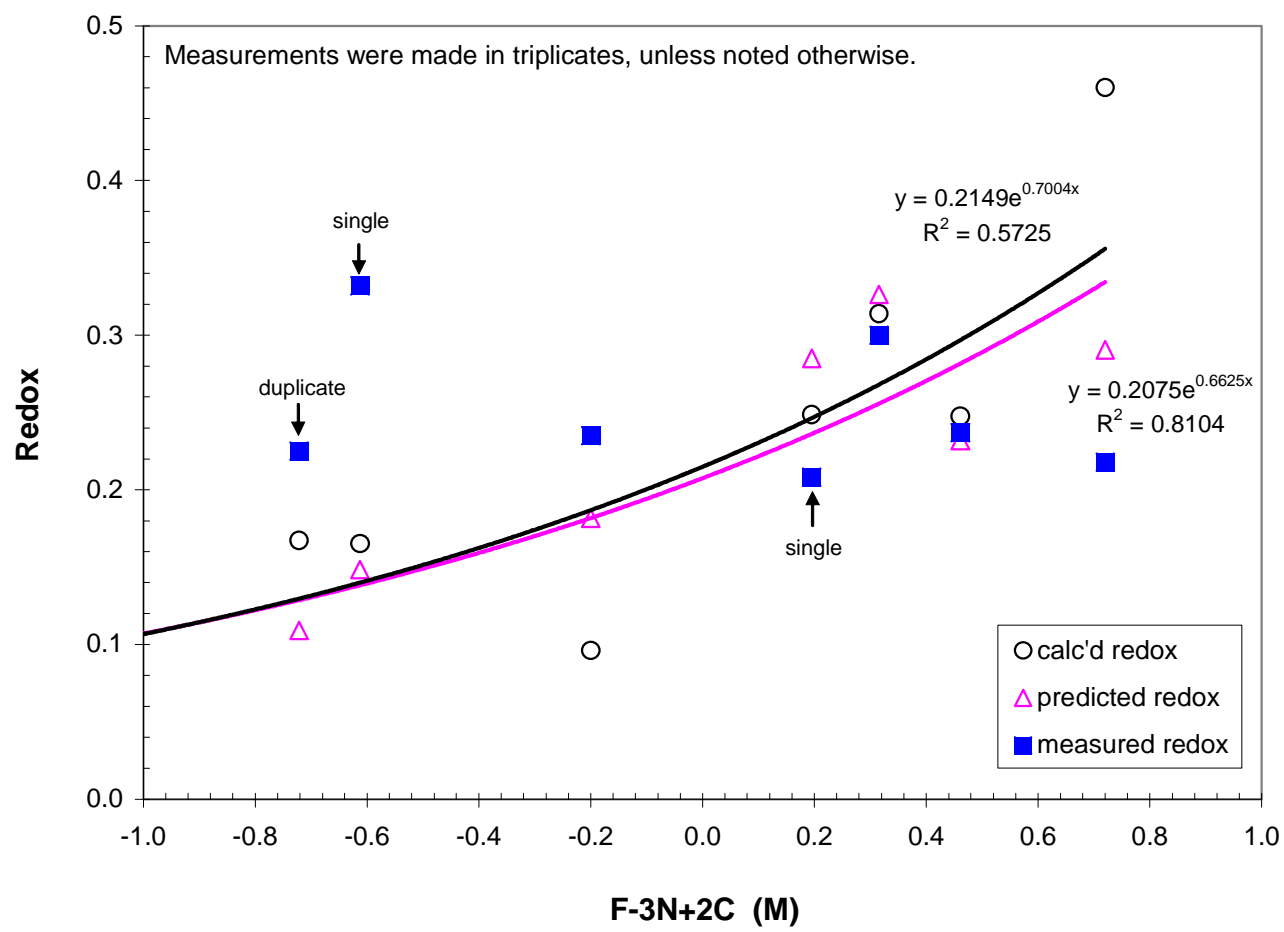
Figure 3-9. Calculated, Predicted, and Measured Redox vs. Net Reducing Potential of
Baseline SB10 Feeds.

\subsubsection{Results of Off-Gas Dynamics Model Runs}

Typical results of the $9 \mathrm{X} / 5 \mathrm{X}$ off-gas surge simulation for normal bubbled melter operation are shown in Figure 3-10 for the baseline SB10-1 feed as an example. It shows the transient profiles of the calcine gas flow into the melter vapor space, melter pressure, melter vapor space gas temperature and the concentration of flammable gases in the Off-Gas Condensate Tank (OGCT) in terms of percent of the LFL during the first 2 and $1 / 2$ minutes into the surge. The magnitude of $9 \mathrm{X} / 5 \mathrm{X}$ surge is clearly seen from the melter pressure peaking at over $+15^{\prime \prime} \mathrm{H}_{2} \mathrm{O}$, compared to $+2 "$ $\mathrm{H}_{2} \mathrm{O}$ for the $3 \mathrm{X}$ non-bubbled off-gas surge. After steam has condensed out in the quencher, the concentration of flammable gases in the remaining off-gas is shown to peak at $\sim 45 \%$ of the LFL from the initial value of $13 \%$ of the LFL about 20 seconds after the gas temperature reached its minimum during normal bubbled operation. It is noted that this peak off-gas flammability is well under the safety basis limit of $<60 \%$ of the LFL for normal operation.

The peak concentrations of flammable gases read off from these figures are summarized in Table 3-43 along with key input variables. It is shown that the calculated peak off-gas flammability for all seven SB10 baseline feeds is well under the safety basis limit. Although not presented here, the calculated peak flammability for seismic operation is also significantly below the safety basis limit of $<95 \%$ of the LFL. Therefore, it can be concluded that there is no flammability concern for all SB10 baseline feeds for both normal and seismic operations. Furthermore, there appears to 
Figure 3-10. Results of 9X/5X Off-Gas Surge Simulation with Baseline SB10-1 Feed. (Normal Operation, 100\% Acid Stoichiometry, 20,727 ppm TOC, 17,863 ppm Coal-carbon, 1.5 GPM Feed Rate; TI4085D $=460^{\circ}$ C; FIC3221A = 900 PPH; FIC3221B = 233 PPH).
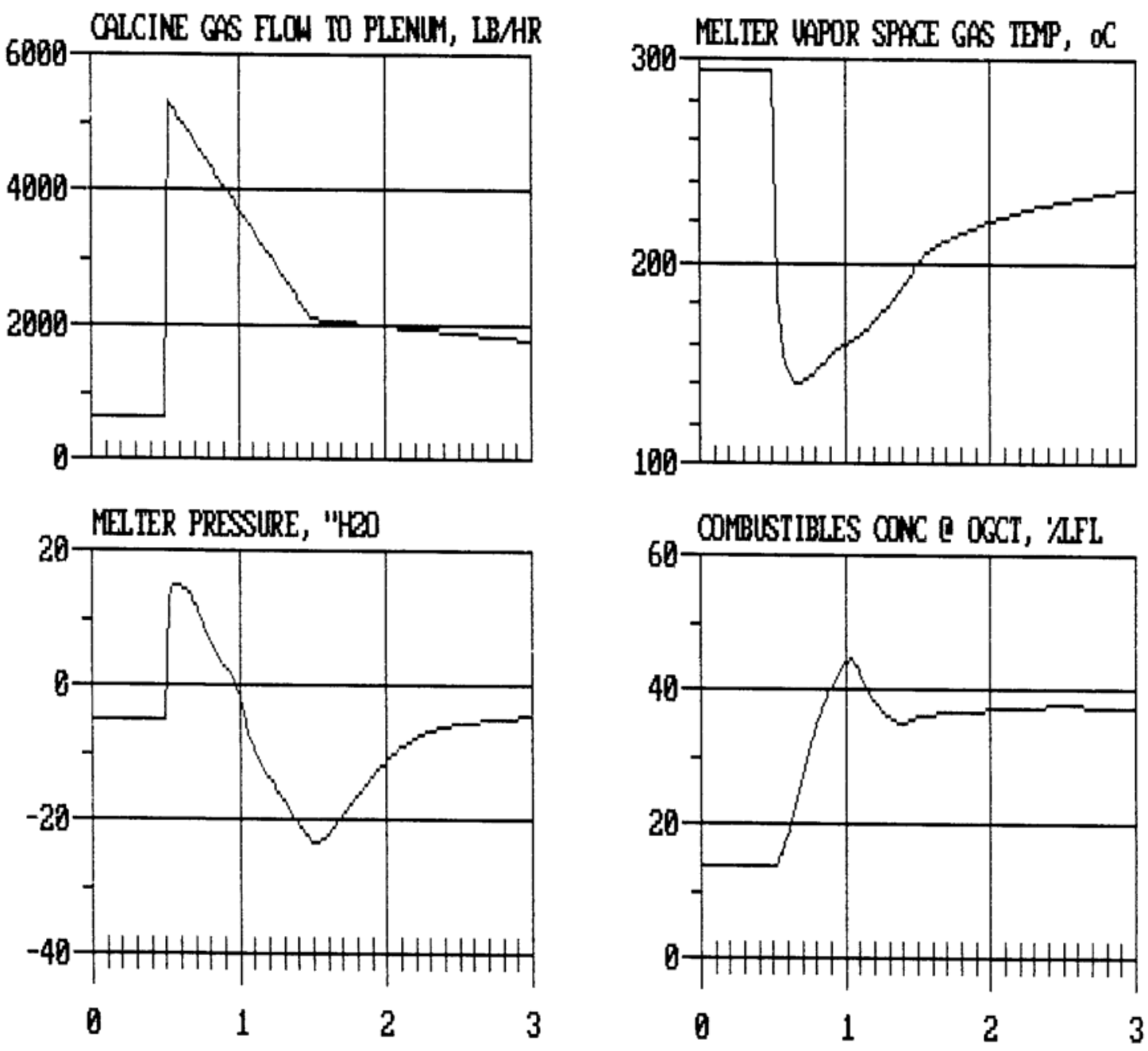

TIME IN MINUTES 
Table 3-43. Calculated Peak Flammability of Baseline SB10 Off-Gas @ OGCT during 9X/5X Surge at 1.5 GPM.

\begin{tabular}{|l|c|c|c|c|c|c|c||}
\hline Feed & $\begin{array}{c}\text { NO3 } \\
\text { (ppm) }\end{array}$ & $\begin{array}{c}\text { Formate } \\
\text { Carbon } \\
\text { (ppm) }\end{array}$ & $\begin{array}{c}\text { Coal- } \\
\text { carbon } \\
\text { (ppm) }\end{array}$ & $\begin{array}{c}\text { TOC } \\
\text { (ppm) }\end{array}$ & $\begin{array}{c}\text { F-3N+2C } \\
\mathbf{( M )}\end{array}$ & $\begin{array}{c}\text { Calculated } \\
\text { Redox }\end{array}$ & $\begin{array}{c}\text { Peak } \\
\text { Flammability } \\
\text { (\%LFL) }\end{array}$ \\
\hline SB10-1 & 62,064 & 2,865 & 17,863 & 20,727 & 0.315 & .314 & 45 \\
\hline SB10-2 & 55,209 & 5,573 & 14,055 & 19,628 & 0.195 & 0.249 & 34 \\
\hline SB10-3 & 55,601 & 4,240 & 11,153 & 15,393 & -0.721 & 0.167 & $\sim 0$ \\
\hline SB10-5 & 39,489 & 9,415 & 5,955 & 15,370 & -0.200 & 0.096 & 7 \\
\hline SB10-7 & 18,339 & 14,332 & 0 & 14,332 & 0.461 & 0.248 & 21 \\
\hline SB10-8 & 16,776 & 15,452 & 0 & 15,452 & 0.720 & 0.460 & 28 \\
\hline SB10-9 & 54,767 & 9,298 & 8,739 & 18,037 & -0.613 & 0.165 & $\sim 0$ \\
\hline
\end{tabular}

be no definite correlation between TOC and off-gas flammability. For example, despite high TOC, the peak flammability of SB10-9 off-gas is zero, while other feeds with lower TOC like SB10-7 are predicted to have much higher flammability potential. However, this is not unexpected since the TOC only reflects the reductant, whereas the reducing effect of TOC can be overwhelmed by a high concentration of nitrate as in SB10-9, resulting in a very oxidizing feed.

By contrast, the calculated peak off-gas flammability appears to be better correlated with the net reducing potential, as expected. It is also of interest to note that the model predicts more sharply increasing off-gas flammability with increasing net reducing potential for feeds with coal than those without coal. Table 3-43 also shows that the coal carbon has a greater reducing potential than the formate carbon, thus making glass more reducing and off-gas more flammable. For example, when SB10-2 and SB10-9 are compared, the former has only about 8\% higher TOC than the latter at a comparable nitrate level but the peak off-gas flammability of the former is $34 \%$ of the LFL compared to $0 \%$ for the latter. The difference is in the TOC makeup; the TOC of SB10-9 is split roughly 50:50 between the formate carbon and coal-carbon, while the split for SB10-2 is 28:72 in favor of coal-carbon. However, the impact of TOC makeup on redox does not appear to be as pronounced as on the off-gas flammability; the glass redox was increased from 0.165 (SB10-9) to 0.249 (SB10-2).

\subsubsection{Flammability Assessment of Max-Coal Feeds}

Since the potential for off-gas flammability of all baseline feeds was well below the safety basis limits, additional coal-carbon was added to each baseline feed iteratively until the calculated peak off-gas flammability equaled the safety basis limit for normal operation, $60 \%$ of the LFL. It is noted that in all the cases considered for DWPF the safety basis limit for normal operation has been more controlling than the seismic limit ( $95 \%$ of the LFL); therefore, the former limit was used here.

\subsubsection{Cold Cap Model Input}

Since coal-carbon was the only species added to the baseline feeds, the input vectors for the maxcoal feeds were identical to those shown in Table 3-34 to Table 3-40 except that the feed rate of coal-carbon to Stages 1 to 3 for each baseline feed were increased by the same factor. Therefore, the equivalent cold cap model input tables for the max-coal SB10 feeds are not repeated here. Likewise, the charge-reconciled max-coal SB10 melter feed compositions are identical to Tables D-1 to D-7 except for higher coal-carbon flows so they are not repeated in Appendix D either. 


\subsubsection{Cold Cap Model Output}

The compositions of both calcine gases and glasses predicted by the cold cap model are shown in Table 3-44 and Table 3-45, respectively, for the SB10 max-coal feed cases; these compositions or flow rates were found after several iterations to give the peak off-gas flammability equaling $60 \%$ of the LFL during the $9 \mathrm{X} / 5 \mathrm{X}$ off-gas surge. It is noted that the max-coal feeds have $6-33 \%$ higher TOC than the baseline feeds and all exceed or at least equal the TSR limit. As a result, the calcine gases for the max-coal feeds are more reduced, as indicated by higher molar ratios of $\mathrm{CO} / \mathrm{CO}_{2}$ and $\mathrm{H}_{2} /\left(\mathrm{CO}+\mathrm{CO}_{2}\right)$ than those of the baseline feeds, particularly for SB10-3 and SB10-9. The higher flammability potential of the max-coal feeds is due in part to the fact that additional coal-carbon was added without adding counterbalancing nitrate, whereas all baseline feeds were redox-balanced. As stated earlier, the intent of adding extra coal-carbon without the accompanying increase in nitrate is to simulate the scenario of slugs of coal-carbon entering the melter.

Table 3-44. Calculated Calcine Gas Compositions for Max-Coal Feeds at 1.5 GPM.

\begin{tabular}{|l|c|c|c|c|c|c|c|}
\hline & $\begin{array}{r}\text { SB10-1 } \\
(\mathrm{gmole} / \mathrm{hr})\end{array}$ & $\begin{array}{r}\text { SB10-2 } \\
(\mathrm{gmole} / \mathrm{hr})\end{array}$ & $\begin{array}{r}\text { SB10-3 } \\
(\mathrm{gmole} / \mathrm{hr})\end{array}$ & $\begin{array}{r}\text { SB10-5 } \\
(\mathrm{gmole} / \mathrm{hr})\end{array}$ & $\begin{array}{r}\text { SB10-7 } \\
(\mathrm{gmole} / \mathrm{hr})\end{array}$ & $\begin{array}{r}\text { SB10-8 } \\
(\mathrm{gmole} / \mathrm{hr})\end{array}$ & $\begin{array}{r}\text { SB10-9 } \\
(\mathrm{gmole} / \mathrm{hr})\end{array}$ \\
\hline $\mathrm{H}_{2} \mathrm{O}$ & 410.791 & 413.663 & 558.697 & 666.841 & 734.296 & 774.739 & 588.502 \\
\hline $\mathrm{CO}_{2}$ & 732.082 & 734.302 & 722.367 & 720.065 & 689.810 & 696.967 & 821.754 \\
\hline $\mathrm{H}_{2}$ & 164.188 & 177.294 & 169.661 & 184.629 & 197.497 & 199.408 & 185.414 \\
\hline $\mathrm{N}_{2}$ & 250.415 & 216.641 & 228.837 & 162.297 & 82.060 & 69.523 & 223.684 \\
\hline $\mathrm{CO}$ & 181.740 & 195.474 & 136.248 & 123.827 & 115.236 & 111.422 & 160.807 \\
\hline $\mathrm{O}_{2}$ & 0 & 0 & 0 & 0 & 0 & 0 & 0 \\
\hline $\mathrm{SO}_{2}$ & 0.015 & 0.003 & 0.022 & 0.007 & $4.32 \mathrm{E}-04$ & $4.43 \mathrm{E}-04$ & 0.008 \\
\hline $\mathrm{NO}^{2}$ & 0 & 0 & 0 & 0 & 0 & 0 & 0 \\
\hline $\mathrm{NO}_{2}$ & 0 & 0 & 0 & 0 & 0 & 0 & 0 \\
\hline $\mathrm{NaBO}_{2}$ & $3.20 \mathrm{E}-04$ & $3.09 \mathrm{E}-04$ & $3.68 \mathrm{E}-04$ & $3.89 \mathrm{E}-04$ & $3.86 \mathrm{E}-04$ & $3.99 \mathrm{E}-04$ & $3.99 \mathrm{E}-04$ \\
\hline $\mathrm{Total}^{2}$ & $1,739.231$ & 1737.378 & 1815.832 & 1857.666 & 1818.900 & 1852.059 & 1980.171 \\
\hline $\mathrm{CO} / \mathrm{CO}_{2}$ & 0.248 & 0.266 & 0.189 & 0.172 & 0.167 & 0.160 & 0.196 \\
\hline $\begin{array}{l}\mathrm{H}_{2} / \\
\left(\mathrm{CO}+\mathrm{CO}_{2}\right)\end{array}$ & 0.180 & 0.191 & 0.198 & 0.219 & 0.245 & 0.247 & 0.189 \\
\hline $\mathrm{TOC}(\mathrm{ppm})$ & 21,894 & 22,849 & 20,009 & 19,815 & 19,003 & 18,798 & 23,147 \\
\hline
\end{tabular}

The calculated redox ratios of the max-coal glasses are shown in Table 3-45 to be much higher than those of the baseline glasses. At redox ratio $>\sim 0.45$, all nickel and manganese spinels are converted to their oxides. At even higher redox ratios of SB10-7 and SB10-8, some or all of the nickel oxide is further reduced mostly to elemental $\mathrm{Ni}$ and some to $\mathrm{Ni}_{3} \mathrm{~S}_{2}$. At redox ratio $>\sim 0.35$ no hematite is predicted to form. The abundance ranking of the melt-phase species remains fairly constant except for those containing iron, e.g., ferrous oxide ( $\mathrm{FeOl}$ ), ferrous silicate $\left(\mathrm{Fe}_{2} \mathrm{SiO}_{4} \mathrm{l}\right)$, magnetite $\left(\mathrm{Fe}_{3} \mathrm{O}_{4} \mathrm{l}\right)$; this is not surprising since redox is the manifestation of how iron partitions itself among various oxidation states. It is also noted that the redox of all SB10 max-coal glasses except for SB10-3 exceeded the DWPF upper limit of 0.3. Furthermore, since both SB10-7 and SB10-8 baseline feeds did not contain any coal, the max-coal to baseline feed coal ratios for these feeds are infinite; for the remaining feeds the ratio ranged from 1.06 (SB10-1) to 1.75 (SB10-5). 
Table 3-45. Calculated Glass Compositions of Max-Coal Feeds at 1.5 GPM.

\begin{tabular}{|c|c|c|c|c|c|c|c|}
\hline & $\begin{array}{r}\text { SB10-1 } \\
\text { (gmole/hr) }\end{array}$ & $\begin{array}{r}\text { SB10-2 } \\
\text { (gmole/hr) }\end{array}$ & $\begin{array}{r}\text { SB10-3 } \\
\text { (gmole/hr) }\end{array}$ & $\begin{array}{r}\text { SB10-5 } \\
\text { (gmole/hr) }\end{array}$ & $\begin{array}{r}\text { SB10-7 } \\
\text { (gmole/hr) }\end{array}$ & $\begin{array}{r}\text { SB10-8 } \\
\text { (gmole/hr) }\end{array}$ & $\begin{array}{r}\text { SB10-9 } \\
\text { (gmole/hr) } \\
\end{array}$ \\
\hline \multicolumn{8}{|l|}{ Melt Phase } \\
\hline $\mathrm{SiO}_{2} 1$ & $1,254.511$ & $1,244.441$ & $1,274.699$ & $1,152.072$ & $1,067.715$ & $1,147.092$ & $1,103.854$ \\
\hline $\mathrm{Na}_{2} \mathrm{SiO}_{3}$ & 378.047 & 286.949 & 394.604 & 460.367 & 494.340 & 502.186 & 473.626 \\
\hline $\mathrm{LiBO}_{2} 1$ & 286.546 & 273.802 & 309.895 & 302.018 & 300.358 & 316.711 & 294.048 \\
\hline $\mathrm{LiAlO}_{2} 1$ & 162.873 & 155.092 & 217.970 & 239.299 & 237.099 & 242.444 & 215.365 \\
\hline $\mathrm{Fe}_{3} \mathrm{O}_{4} \mathrm{l}$ & 123.409 & 111.352 & 106.928 & 140.439 & 30.473 & 29.637 & 118.849 \\
\hline $\mathrm{MgSiO}_{3} 1$ & 10.772 & 10.538 & 11.551 & 10.614 & 9.660 & 11.570 & 13.076 \\
\hline $\mathrm{FeO} 1$ & 26.570 & 60.679 & 23.022 & 54.522 & 144.545 & 148.258 & 49.688 \\
\hline $\mathrm{CaFe}_{2} \mathrm{O}_{4}$ & 14.501 & 5.954 & 14.234 & 8.521 & 0.840 & 0.808 & 6.776 \\
\hline $\mathrm{B}_{2} \mathrm{O}_{3} \mathrm{l}$ & $8.72 \mathrm{E}-05$ & $8.31 \mathrm{E}-05$ & $1.14 \mathrm{E}-04$ & $1.29 \mathrm{E}-04$ & $1.28 \mathrm{E}-04$ & $1.30 \mathrm{E}-04$ & $1.14 \mathrm{E}-04$ \\
\hline $\mathrm{Ca}_{2} \mathrm{SiO}_{4}$ & 19.384 & 22.348 & 17.752 & 18.490 & 24.459 & 24.497 & 14.029 \\
\hline $\mathrm{Ca}_{3} \mathrm{MgSi}_{2}{ }^{*}$ & 2.687 & 3.390 & 2.423 & 2.476 & 3.532 & 3.896 & 2.140 \\
\hline $\mathrm{Fe}_{2} \mathrm{SiO}_{4}$ & 5.070 & 28.229 & 3.617 & 18.138 & 116.175 & 119.121 & 15.583 \\
\hline $\mathrm{KBO}_{2}$ & 0.402 & 0.366 & 0.528 & 0.508 & 0.429 & 0.432 & 0.459 \\
\hline $\mathrm{Li}_{2} \mathrm{O} 1$ & 109.505 & 104.925 & 97.667 & 81.905 & 81.665 & 89.986 & 88.380 \\
\hline $\mathrm{K}_{2} \mathrm{SiO}_{3}$ & 2.643 & 2.370 & 3.419 & 2.506 & 1.660 & 1.708 & 2.327 \\
\hline \multicolumn{8}{|c|}{ Spinel Phase } \\
\hline $\mathrm{NiFe}_{2} \mathrm{O}_{4}$ & 12.122 & 0 & 13.078 & 4.645 & 0 & $\overline{0}$ & 0.411 \\
\hline $\mathrm{Mn}_{3} \mathrm{O}_{4}$ & 29.955 & 0 & 24.086 & 9.234 & 0 & 0 & 0.912 \\
\hline $\mathrm{CuFe}_{2} \mathrm{O}_{4}$ & 0.839 & 0 & 0 & 0 & 0 & 0 & 0 \\
\hline $\mathrm{MgFe}_{2} \mathrm{O}_{4}$ & 0.080 & 0 & 0.074 & 0.015 & 0 & 0 & 0.002 \\
\hline \multicolumn{8}{|l|}{ ICP } \\
\hline $\mathrm{Fe}_{2} \mathrm{O}_{3}$ & 7.883 & 0 & 83.299 & 0 & 0 & 0 & 0 \\
\hline $\mathrm{CaSO}_{4}$ & 0.652 & 0.712 & 0.235 & 0.396 & 0 & 0 & 9.394 \\
\hline $\mathrm{Ni}$ & 0 & 0 & 0 & 0 & 4.779 & 12.822 & 0 \\
\hline $\mathrm{NiO}$ & 0.652 & 12.275 & 0 & 7.791 & 6.183 & 0 & 9.976 \\
\hline $\mathrm{Ni}_{3} \mathrm{~S}_{2}$ & 0 & 0 & 0 & 0 & 0.300 & 0.209 & 0 \\
\hline $\mathrm{Cu}$ & 0 & 0.642 & 0 & 0 & 0.866 & 0 & 0 \\
\hline $\mathrm{MnO}$ & 7.883 & 86.282 & 0 & 43.187 & 90.899 & 91.871 & 54.769 \\
\hline \multicolumn{8}{|c|}{$\operatorname{Redox}\left(\mathrm{Fe}^{+2} / \mathrm{Fe}^{\text {total }}\right)$} \\
\hline Calculated & 0.335 & 0.493 & 0.240 & 0.429 & 0.867 & 0.872 & 0.442 \\
\hline Predicted & 0.394 & 0.479 & 0.372 & 0.433 & 0.497 & 0.477 & 0.440 \\
\hline Measured & $\mathrm{n} / \mathrm{a}$ & $\mathrm{n} / \mathrm{a}$ & $\mathrm{n} / \mathrm{a}$ & $\mathrm{n} / \mathrm{a}$ & $\mathrm{n} / \mathrm{a}$ & $\mathrm{n} / \mathrm{a}$ & $\mathrm{n} / \mathrm{a}$ \\
\hline TOC (ppm) & 21,894 & 22,849 & 20,009 & 19,815 & 19,003 & 18,798 & 23,147 \\
\hline
\end{tabular}

* The melt species $\mathrm{Ca}_{3} \mathrm{MgSi}_{2}$ is a truncated name for $\mathrm{Ca}_{3} \mathrm{MgSi}_{2} \mathrm{O}_{8}$ or $3 \mathrm{CaO} \cdot \mathrm{MgO} .2 \mathrm{SiO}_{2}$. 
The calculated redox ratios of both the max-coal and baseline glasses using the cold cap model are next plotted in Figure 3-11 against the net reducing potential. Both data sets were regressed using an exponential function and the resulting curves are shown to maintain a good continuity at the net reducing potential between 0.6 and 0.7. However, the curve for the max-coal feed is seen to have a steeper slope than the baseline curve. Since no redox data are available at these high net reducing potentials, it is not certain that a sharper upturn in redox at high net reduction potential is a real trend or the model is simply over predicting redox. However, comparison of the calculated redox ratios for SB10-7 and SB10-8 against those predicted from Eq. (1) suggests that it is likely the latter.

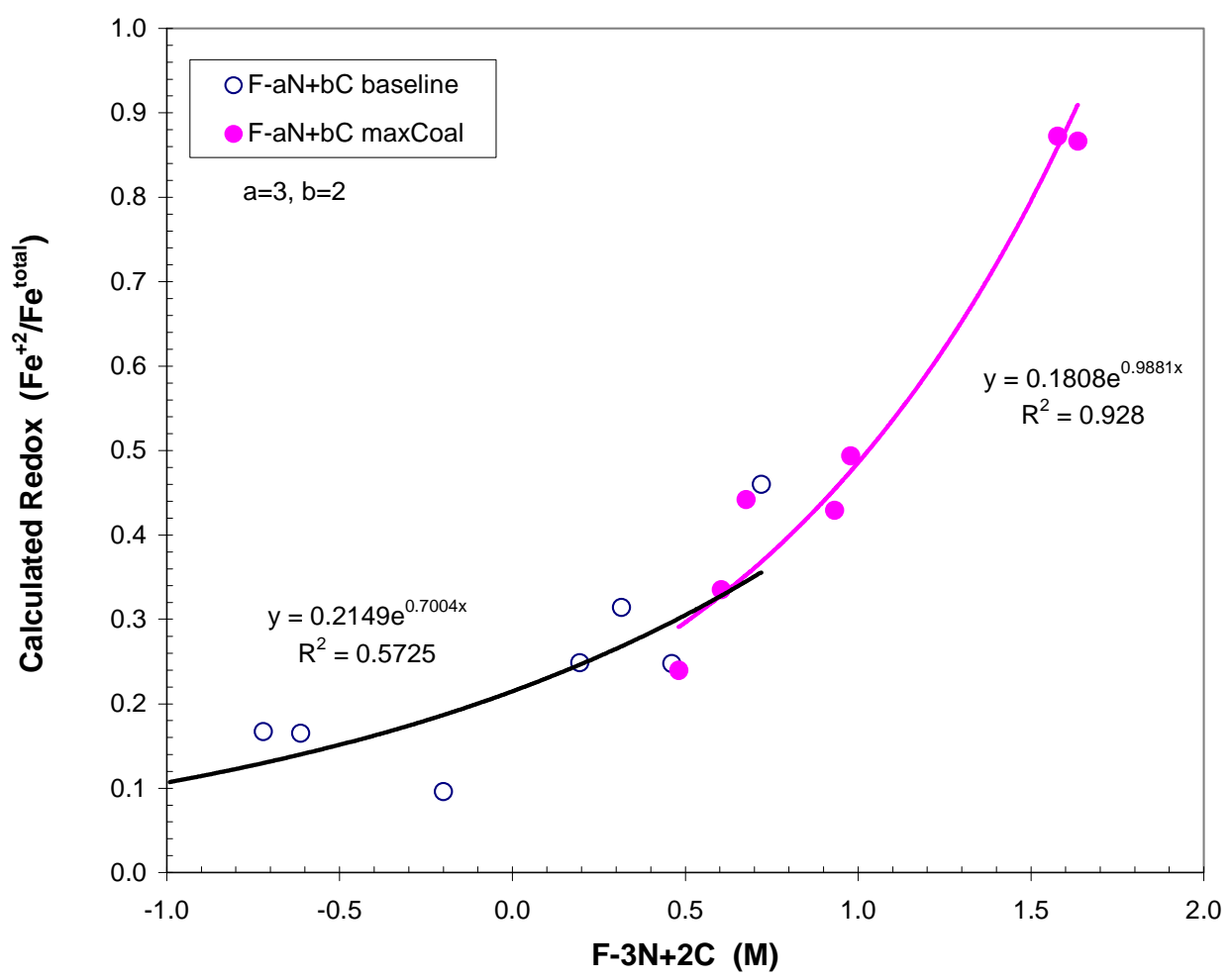

Figure 3-11. Calculated Redox vs. Net Reducing Potential of Max-Coal SB10 Feeds.

\subsubsection{Off-Gas Dynamics Model Input}

The calcine gas compositions given in Table 3-44 for the max-coal feeds were used as the input to the off-gas dynamics model. As stated above, these calcine gas flows were found to give the peak off-gas flammability equaling the safety basis limit for normal operation for each max-coal feed. It is to be noted that all other input parameters of the model such as process and controller constants remained the same as in the baseline feed cases.

\subsubsection{Results of Off-Gas Dynamics Model Runs}

Typical results of the $9 \mathrm{X} / 5 \mathrm{X}$ off-gas surge simulation for normal bubbled melter operation are shown in Figure 3-12 for the SB10-1 max-coal feed as an example. Since the amount of extra coal added to the baseline feeds was not large, ranging from 1,200 to 5,200 ppm, the transient profiles of the calcine gas flow into the melter vapor space, melter pressure, and melter vapor space gas temperature are virtually identical to those shown in Figure 3-10. The only difference 
is in the concentration profile for the flammable gases in the OGCT. As discussed earlier, the flammable gas concentration profile was set to peak at the safety basis limit of $60 \%$ of the LFL for each max-coal feed. It is interesting to note that while the melter pressure is shown to recover within $\sim 2$ minutes after the onset of surge, the flammable gas concentration remains relatively high for a longer period of time after the initial quick descent from its peak value in both the baseline and max-coal feed cases. It is not clear why this is the case but it could be the result of high surge magnitudes of bubbled melter operation coupled with the slow recovery of the melter vapor space temperature.

The maximum coal content that each SB10 feed can accommodate without exceeding the off-gas flammability safety basis for normal operation are summarized in Table 3-47 along with other input variables. The maximum coal content is further broken down into that included in each baseline feed and the extra added later. It is shown that the maximum coal limit can vary widely from 3,400 ppm to over 19,000 ppm, depending on how each feed was blended from two SB10 simulants and, more importantly, how the acid addition was done, as outlined in Table 3-10.

For example, the lower bound for the maximum coal limit is set by SB10-8 and this was expected since it contains the most formate carbon and least nitrate. As a result, SB10-8 has the smallest TOC and one of the largest net reducing potential. On the other hand, the upper bound for the maximum coal-carbon limit is set by SB10-1, since it contains the least formate carbon and most nitrate, resulting in the smallest net reducing potential. Because of this counterbalancing between the formate carbon and coal-carbon at a given nitrate level, the resulting TOC at the safety basis limit does not vary as widely as the maximum coal-carbon limit, ranging from 19,000 ppm to $23,100 \mathrm{ppm}$.

Table 3-46. Maximum Coal-carbon Limits for SB10 Feeds at 60\% of LFL.

\begin{tabular}{||c|c|c|c|c|c|c|c||}
\hline \hline Feed & $\begin{array}{c}\mathbf{N O}_{3} \\
\mathbf{( p p m )}\end{array}$ & $\begin{array}{c}\text { Formate } \\
\text { Carbon } \\
\mathbf{( p p m )}\end{array}$ & $\begin{array}{c}\text { Baseline } \\
\text { Coal } \\
\mathbf{( p p m )}\end{array}$ & $\begin{array}{c}\text { Additional } \\
\text { Coal- } \\
\text { carbon } \\
\mathbf{( p p m )}\end{array}$ & $\begin{array}{c}\text { Maximum } \\
\text { Coal- } \\
\text { carbon } \\
\mathbf{( p p m )}\end{array}$ & $\begin{array}{c}\text { TOC } \\
\mathbf{( p p m )}\end{array}$ & $\begin{array}{c}\text { F-3N+2C } \\
\mathbf{( M )}\end{array}$ \\
\hline SB10-1 & 61,990 & 2,861 & 17,841 & 1,191 & 19,032 & 21,894 & 0.605 \\
\hline SB10-2 & 55,028 & 5,555 & 14,009 & 3,285 & 17,294 & 22,849 & 0.979 \\
\hline SB10-3 & 55,115 & 4,203 & 11,056 & 4,750 & 15,806 & 20,009 & 0.481 \\
\hline SB10-5 & 39,310 & 9,372 & 5,928 & 4,515 & 10,443 & 19,815 & 0.932 \\
\hline SB10-7 & 18,252 & 14,264 & 0 & 4,739 & 4,739 & 19,003 & 1.635 \\
\hline SB10-8 & 16,719 & 15,399 & 0 & 3,399 & 3,399 & 18,798 & 1.577 \\
\hline SB10-9 & 54,482 & 9,249 & 8,694 & 5,204 & 13,898 & 23,147 & 0.675 \\
\hline
\end{tabular}


Figure 3-12. Results of 9X/5X Off-Gas Surge Simulation with SB10-1 Max-Coal Feed.

(Normal Operation, 100\% Acid Stoichiometry, 21,894 ppm TOC, 19,032 ppm Coal, 1.5 GPM Feed Rate; TI4085D $=460^{\circ} \mathrm{C}$; FIC3221A = 900 PPH; FIC3221B = 233 PPH).
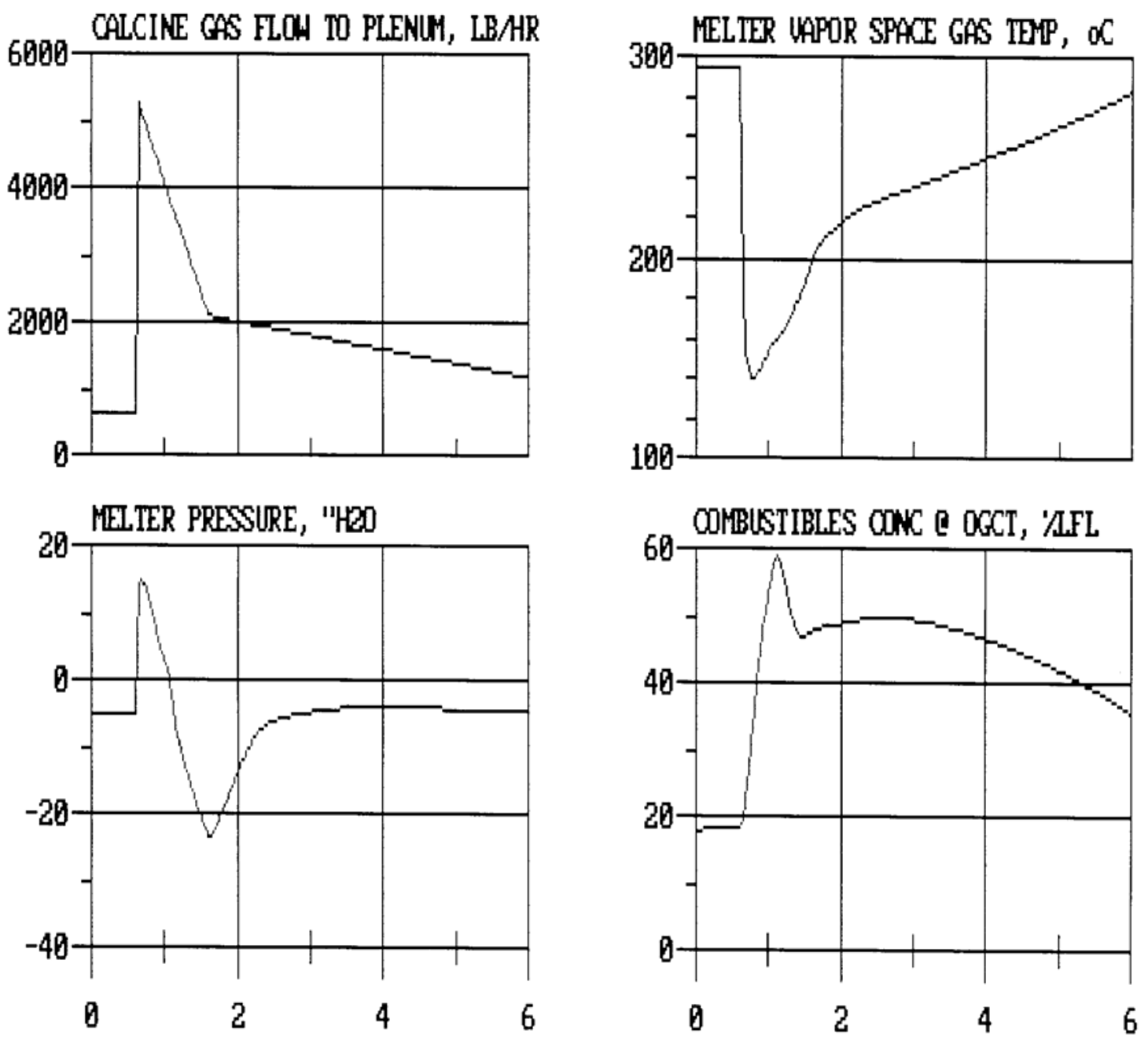

\section{TIME IN MINUTES}

However, the counterbalancing between the formate carbon and coal-carbon is not clearly seen in Table 3-47 for the remaining "non-extreme" cases. When SB10-2 and SB10-3 are compared, both have comparable nitrate levels but it is the former that can accommodate more coal-carbon despite having more formate carbon than the latter. As a result, SB10-2 has a higher TOC but still end up with the same peak off-gas flammability as SB10-3. Nevertheless, the larger net reducing potential of SB10-2 had the expected impact on glass redox, i.e., 0.49 vs. 0.24 for SB103 (see Table 3-46) and the resulting speciation in the spinel phase and ICP of SB10-2 glass was quite the opposite of SB10-3. This could mean that the larger net reducing potential of SB10-2 was affecting the glass phase more heavily, thus leaving more oxygen available for the oxidation of calcine gases. 
On the other hand, the impact of nitrate (oxidant) on the coal-carbon and TOC limits can be clearly seen when SB10-5 and SB10-9 are compared. Both have comparable formate carbon; however, since SB10-9 has 39\% higher nitrate, it could accommodate 33\% more coal-carbon, resulting in a $17 \%$ higher TOC. It is be noted that although the nitrate and format remained the same in the baseline and max-coal feeds, their concentrations given in Table 3-44 and Table 3-47 are not quite identical. The slight differences are due to the fact that just by adding additional coal-carbon the density of the max-coal feeds became a little higher than their baseline counterparts, thereby lowering their concentrations in the max-coal feed slightly.

\subsection{Impact of FBSR Stream on Tank Farm and Other Processing Facilities}

The FBSR PDT material will be transferred into Tank 42 and Tank 51 for washing prior to transferring to Tank 40 prior to feeding to DWPF. All three tanks will contain some coal-carbon once the FBSR facility begins transferring product. Large insoluble solids are harder to suspend and will settle faster if mixing is inadequate or not being performed. It should be noted that after redissolution of the PDT material and settling, the insoluble solids were difficult to resuspend. However, during SRNL washing and preparation of the sludge simulants, after combining the PDT material and the sludge, the settled solids were easily resuspended. They also settled quickly making the washing of this material much easier than many sludges. In addition, no solids were seen floating or sticking to the plastic vessels during washing nor did solids accumulate in the SRAT/SME glassware. Note that no carbon steel equipment was used in the testing.

One impact that may be significant is the quantity of sodium carbonate that will be transferred to the Tank Farm during the washing operations. Depending on the size of the decant, at least $90 \%$ of the sodium carbonate in the PDT material will be removed from the sludge and will need to be processed in the Tank Farm. It is recommended that future testing be completed with the wash solution to determine whether this large quantity of sodium carbonate will impact the HLW evaporators or evaporator drop tank. The decanted supernate from washing SB10-B simulant has been collected and retained. These could be used for future downstream testing. No analysis was completed on these decanted supernates. 


\subsection{Conclusions}

In order to determine the carbon limit for the Defense Waste Processing Facility (DWPF), seven different SB10 feed simulants were formulated at varying coal-carbon concentrations and tested during a bench-scale CPC demonstration to assess the impact of coal-carbon on the CPC processing goals such as nitrite destruction and redox. The resulting melter feed compositions were then assessed in terms of the potential for melter off-gas flammability using the DWPF cold cap and off-gas dynamics models. This report summarizes the results of these experimental and modeling studies and draws several conclusions including the maximum allowable coal-carbon limit for DWPF without exceeding the off-gas flammability safety basis limits.

Carbon (coal) will be added to the sludge processed by DWPF once the Fluidized Bed Steam Reformer (FBSR) process starts up in order to destroy the tetraphenylborate (TPB) present in Tank 48. Carbon is present in the FBSR product due to unreacted coal-carbon, an FBSR additive.

The FBSR product will be combined with sludge and washed together to produce the sludge batch that DWPF will process. The FBSR product is high in both sodium carbonate and coalcarbon. Most of the sodium carbonate is removed during washing but all of the coal-carbon will become part of the DWPF sludge batch.

An earlier report was issued based on paper studies with no insight from experimental data. This report adds the results and analysis of the experiments. The presence of coal-carbon in the sludge feed to DWPF has both positive and negative impact as summarized below:

- Coal-carbon is a melter reductant. If excess coal-carbon is present, the resulting melter feed may be too reducing, potentially shortening the melter life. During this study, the Reduction/Oxidation Potential (REDOX) of the melter could be controlled by varying the ratio of nitric and formic acid. However, higher coal-carbon concentrations than were studied could lead to glass that is too reducing if not balanced.

- The addition of coal-carbon increases the amount of nitric acid added and decreases the amount of formic acid added to control melter REDOX. This means the DWPF flowsheet with the FBSR product is much more oxidizing than current CPC processing. In this study, adequate formic acid was present in all experiments to reduce mercury and manganese, two of the main goals of CPC processing, but did not lead to adequate mercury stripping in the SRAT cycle in two of the experiments. However, higher coal-carbon concentrations than were studied could lead to glass that is too reducing if not balanced.

- Coal-carbon will decompose to carbon dioxide or carbon monoxide in the melter. The addition of coal-carbon to the FBSR product will lead to approximately $55 \%$ higher offgas production from formate, nitrate and carbon due to the decomposition of the carbon at the maximum levels in this testing. Higher offgas production could lead to higher cold cap coverage or melter foaming which could decrease melt rate. No testing was performed to evaluate the impact of the higher melter offgas flow.

- The FBSR product contains 4.1 to $9.5 \%$ by mass coal-carbon particles with a particle size $>177 \mu \mathrm{m}$ (maximum particle size for frit). There is concern that the large sludge particles may lead to localized reducing pockets as the large carbon particles react in the melt pool. In addition, the larger particles may plug smaller diameter piping in the DWPF sampling system and will settle faster than smaller particles. No testing was performed to evaluate the impact of the larger particle size on DWPF processing. 
- The hydrogen production is greatly reduced in testing with coal-carbon as less formic acid is added in CPC processing. In the high acid runs, the peak hydrogen generation was 15 times higher in the run with added coal-carbon.

- Coal-carbon is a better melter reducing agent than formic acid, since the content of both carbon and hydrogen are important in evaluating the flammability of the melter offgas. Processing with coal-carbon decreases the amount of formic acid added in the CPC, leading to a lower flammability risk in processing with coal-carbon compared to the current DWPF flowsheet.

A total of 14 cases were considered in the assessment of DWPF melter off-gas flammability using two computer models that describe the cold cap chemistry and off-gas combustion and dynamics. Seven of those cases involved the SB10 simulants which were tested during the bench-scale CPC demonstration, and the resulting baseline SB10 melter feeds were all shown to be well under the off-gas flammability safety basis limits at the peak of the $9 \mathrm{X} / 5 \mathrm{X}$ off-gas surge for bubbled melter operation. The concentration of coal-carbon in the baseline melter feeds varied widely from 0 to $17,863 \mathrm{ppm}$, depending on the acid addition strategy used and the extent to which the required reductant (formic acid) was replaced with coal-carbon. The highest coal-carbon concentration in the baseline SB10 melter feeds occurred when the least amount of formic acid was used at the highest nitrate concentration (SB10-1). On the other hand, the coal-carbon concentration was zero at the two highest formate concentrations coupled with the two lowest nitrate concentrations (SB10-7 and SB10-8). Therefore, the theoretical maximum coal-carbon limit for the melter feed will occur when the formic acid addition is kept to a minimum, as required by the reduction of $\mathrm{Hg}$ and $\mathrm{Mn}$ and the destruction of nitrite, while maintaining as high a nitrate level as possible at a target redox. All baseline feeds were redox-adjusted, and three of the seven baseline melter feeds contained TOC higher than the current DWPF theoretical limit of 18,900 ppm.

Since the off-gas flammability potential for all seven baseline feeds was below the safety basis limits, additional coal-carbon was added to each baseline feed next until the calculated peak offgas flammability during the $9 \mathrm{X} / 5 \mathrm{X}$ off-gas surge equaled the safety basis limit of $60 \%$ of the LFL for normal operation. In doing so, however, no counterbalancing nitrate was added, thus simulating the scenario where slugs of coal-carbon enter the melter as a result of uneven distribution of coal-carbon in the slurry. The results of this "max-coal" feed simulation showed that the amount of additional coal-carbon that can be added before the safety basis limit is exceeded varies from 1,190 ppm (SB10-1) to 5,200 ppm (SB10-9). Including the coal-carbon contained in the baseline feeds, the theoretical maximum coal-carbon concentration that can be processed through the DWPF melter without exceeding the safety basis limits varies from 3,400 ppm (SB10-8) to 19,032 ppm (SB10-1). The resulting TOC, including the excess coal-carbon, would exceed the current DWPF theoretical limit in all SB10 max-coal feeds except SB10-8 whose TOC is just below the theoretical maximum.

\subsection{Recommendations}

The following recommendations are the result of a number of lessons learned during the performance of this testing.

1. The results of this feasibility analysis indicate that the processing of SB10 sludge together with the FBSR product using a coal-carbon concentration of $<9.5 \mathrm{wt} \% \quad(<14,700 \mathrm{mg} / \mathrm{kg}$ carbon) and SWPF products is possible in the CPC. However, since every sludge batch has a different composition and requires different acid addition amounts, this limit should be reevaluated with each new sludge batch as part of the sludge batch qualification program. 
2. The Tank 48 team should attempt to minimize the coal-carbon content in the FBSR product. Minimizing the coal-carbon concentration will also limit the nonradioactive impurities added in waste processing (coal ash, carbon, sulfur, etc.).

3. Develop a method to measure the carbon concentration in washed sludge and CPC slurries. $\mathrm{AD}$ has been unable to accurately measure the carbon concentration with existing instruments and methods.

4. Limit the FBSR product particle size to $<177 \mu \mathrm{m}$. This may require FBSR product particle size reduction.

5. Given the contractual commitments for canister production and waste loading, the impact of FBSR product on melt rate should be experimentally assessed. Melt rate was not measured as part of this study, nor was the optimum frit used during this study.

6. Use a melter for in-situ sampling or post-mortem (destructive) analysis to assess the potential for localized reduction, the formation of metallic precipitates, and/or possible interactions of reduced species (such as nickel sulfides) on materials of construction.

7. Testing of the sludge wash material that was collected during sludge preparation should be used in testing to determine whether this large quantity of sodium carbonate produced during sludge washing will impact the HLW evaporators or Waste Tanks. The decanted supernate from washing SB10-B simulant have been collected and retained.

8. This preliminary study should be reassessed if a new CPC flowsheet is defined and when the FBSR product stream is finalized.

\subsection{Acknowledgements}

The sludge projections for future sludge batches were estimated by Jeff Gillam and David Larsen.

The SWPF cesium and actinide stream projections were provided by Azi Samadi and Celia Aponte.

The experiments were capably performed by SRNL technicians Phyllis Workman, Irene Reamer, Vickie Williams, Jon Duvall, David Healy and Tony Burkhalter. Their long hours, shift work, and careful control of the experiments are greatly appreciated.

The technical support offered by David Koopman, Michael Stone, and Brad Pickenheim in planning these experiments and reviewing the plans and results is very much appreciated.

The calibration, set up and post run analysis of the offgas data by Frances Williams and John Pareizs is appreciated.

The preparation of the simulants by David Healy and David Newell is also appreciated.

The analysis of the hundreds of samples by David Best, Whitney Riley, and Pat Simmons is greatly appreciated. In addition, analysis of rheology samples by Beverly Walls and the carbon analyses by Mike Williams, Sherry Vissage, Carol Jantzen and Kathy White were also appreciated.

The REDOX analysis by David Newell, Holly Hall, and Whitney Riley along with support from Gary Dobos and Curt Sexton of the SRNL glass shop was appreciated. 


\subsection{References}

1 WDPD-09-041, 'Letter of Direction - Tank 48 Business Decision (Re: Letter, Olson to Spears, LWO-EVP-2009-00025, 6/2/09)', June 10, 2009-07-28.

$2 \quad$ Sludge Batch Plan 2009, SRR-LWP-2009-00009, Rev. 0, Oct 2009.

3 Daniel W. E., M. R. Williams, C. M. Jantzen. 2009 THOR ${ }^{\circledR}$ (Thermal Organic Reduction) Engineering Scale Test Demonstration (ESTD) Fluidized Bed Steam Reformer (FBSR) Phase 3 Analytical Results, SRNL-TR-2009-00437, Revision 0, Savannah River Site, Aiken, SC 29808 (2010).

4 Jantzen, C. M. and J. D. Newell, Defense Waste Processing Facility (DWPF) Sludge Batch 5 (SB5) REDOX Validation, SRNL-PSE-2008-00184, Savannah River Site, Aiken, SC 29808 (2008).

5 Fellinger, T. L. 2009 Tank 7F Sludge Slurry Characterization and Wash Studies: Technical Task Request, HLW-DWPF-TTR-2009-0027, Rev. 0, Savannah River Site, Aiken, SC 29808 (2009).

6 Lambert, D. P. , Task Technical and Quality Assurance Plan for DWPF Coal-Carbon WAC Limit Evaluation (Tank 48 Impact Study), SRNL-RP-2010-0126, Rev. 0, Savannah River Site, Aiken, SC 29808 (2010).

7 Lambert, D. P., Choi, A. S., DWPF Coal-Carbon Waste Acceptance Criteria (WAC) Limit Evaluation (Tank 48 Impact Study), SRNL-RP-2010-00155, Rev. 0, Savannah River Site, Aiken, SC 29808 (2010).

8 Samadi, A, Input Sheet for DWPF Coal WAC limit Evaluation (Tank 48 Impact Study), SRRSPT-2010-00010, Rev 0, Savannah River Site, Aiken, SC 29808 (2010).

9 C. M. Jantzen, Comparative Laboratory Measurement of Coal in Tank 48 Fluidized Bed Steam Reformer Samples, SRNL-TR-2010-00165, Rev 0, Savannah River Site, Aiken, SC 29808 (2010).

10 Manual L29, Procedure ITS-00124, Rev 2, SRS HLW Sludge Simulant Preparation Savannah River Site, Aiken, SC 29808 (2008).

11 Stone, M. E., Lab-Scale CPC Equipment Set-up, SRNL-ITS-2006-00074, Savannah River Site, Aiken, SC 29808 (2008).

12 Manual L29, Procedure ITS-0094, Rev. 3, Laboratory Scale Chemical Process Cell Simulations, Savannah River Site, Aiken, SC 29808 (2006)

13 Tank 48 Coal Carbon Study, WSRC-NB-2010-00017.

14 Koopman, D.C., A.I. Fernandez, B.R. Pickenheim, Preliminary Evaluations of Two Proposed Stoichiometric Acid Equations, Revision 0, Savannah River Site, Aiken, SC 29808 (2009).

15 Jantzen, C.M., J.R. Zamecnik, D.C. Koopman, C.C. Herman, and J.B. Pickett, Electron Equivalents Model for Controlling Reduction-Oxidation (REDOX) Equilibrium during High Level Waste (HLW) Vitrification, WSRC-TR-2003-00126, Savannah River Site, Aiken, SC 29808 (2003).

16 Lambert, D. P., Acid Calculation Spreadsheet for DWPF Simulations, Revision 1 (Dated 8/14/06), SRNL-PSE-2006-00173, Savannah River Site, Aiken, SC 29808 (2006).

17 Lambert, D.P., M. E. Stone, B. R. Pickenheim, D. R. Best, D. C. Koopman, Sludge Batch 5 Simulant Flowsheet Studies, SRNS-STI-2008-00024, Revision 0, Savannah River Site, Aiken, SC 29808 (2008).

18 Stone, M. E., FY06 Feed Preparation for Melt Rate Testing, WSRC-STI-2006-0007, Savannah River Site, Aiken, SC 29808 (2006).

19 PT Technical Data Summary for the Defense Waste Processing Facility: Sludge Plant", DPSTD-80-38-2 
Manual L29, Procedure ITS-0052, Rev. 2, Heat Treatment of Waste Slurries for REDOX $\left(\mathrm{Fe}^{2+} / \Sigma \mathrm{Fe}\right) \&$ Chemical Composition Measurement, Savannah River Site, Aiken, SC 29808 (2009).

21 C.M. Jantzen, J.B. Pickett, K.G. Brown, T.B. Edwards and D.C. Beam, Process/Product Models for the Defense Waste Processing Facility (DWPF): Part I Predicting Glass Durability from Composition Using a Thermodynamic Hydration Energy Reaction Model (THERMO), WSRC-TR-93-672, Westinghouse Savannah River Company, Aiken, SC (1995).

22 D.K. Peeler AND T.B. Edwards, Frit Development for Sludge Batch 3, WSRC-TR-200200491, Westinghouse Savannah River Company, Aiken, SC (2002).

23 CM Jantzen, Comparative Laboratory Measurement of Coal in Tank 48 Fluidized Bed Steam Reforming Samples, SRNL-TR-2010-00165, Revision 0, Savannah River National Laboratory, Aiken, SC 29808 (2010).

24 Choi, A. S., Validation of DWPF Melter Off-Gas Combustion Model, WSRC-TR-200000100, Savannah River Site, Aiken, SC 29808 (2000).

25 Choi, A. S., Validation of DWPF MOG Dynamics Model - Phase I, WSRC-TR-96-0307, Savannah River Site, Aiken, SC 29808 (1997).

26 Choi, A. S., DWPF Melter Off-Gas Flammability Assessment, X-CLC-S-00164, Rev. 4 (2010).

27 Plante, E. R., Bonnell, D. W., and Hastie, J. W., Experimental and Theoretical Determination of Oxide Glass Vapor Pressures and Activities, Advances in the Fusion of Glass, Am. Cer. Soc., pp26.1-26.18 (1988). 
SRNL-STI-2010-00589

Revision 0

Appendix A: Acid Calculation Results from Experiments 


\begin{tabular}{|c|c|c|c|c|c|c|c|c|}
\hline \multicolumn{9}{|c|}{ Table A-1. SRNL Acid, Trim Chemical, Dewater and Redox Calculations } \\
\hline Run \# & SB10-1 & SB10-2 & SB10-3 & SB10-5 & SB10-7 & SB10-8 & SB10-9 & Units \\
\hline Run Description: & $\begin{array}{l}\text { Highest FBSR, } \\
100 \% \text { acid } \\
\text { stoichiometry, } \\
\text { redox } 0.2\end{array}$ & $\begin{array}{l}\text { Highest FBSR, } \\
150 \% \text { acid } \\
\text { stoichiometry, } \\
\text { redox } 0.2\end{array}$ & $\begin{array}{l}\text { Highest FBSR, } \\
100 \% \text { acid } \\
\text { stoichiometry, } \\
\text { redox } 0.2\end{array}$ & $\begin{array}{l}\text { Lowest FBSR, } \\
100 \% \text { acid } \\
\text { stoichiometry, } \\
\text { redox } 0.2\end{array}$ & $\begin{array}{l}\text { No FBSR, } \\
100 \% \text { acid } \\
\text { stoichiometry, } \\
\text { redox } 0.2\end{array}$ & $\begin{array}{l}\text { No FBSR, } \\
150 \% \text { acid } \\
\text { stoichiometry, } \\
\text { redox } 0.2\end{array}$ & $\begin{array}{l}\text { Med FBSR, } \\
150 \% \text { acid } \\
\text { stoichiometry, } \\
\text { redox } 0.2 \text { with } \\
\text { ARP/MCU }\end{array}$ & \\
\hline Sludge Feed Batch \# & SB10-B & SB10-B & $\begin{array}{l}\text { Blend of SB10- } \\
\text { A and SB10-B }\end{array}$ & $\begin{array}{l}\text { SB10-A and } \\
\text { Sludge 10-B } \\
\text { Lowest FBSR } \\
\text { Blend }\end{array}$ & SB10-A & SB10-A & $\begin{array}{l}\text { SB10-A/B } \\
\text { Blend }\end{array}$ & \\
\hline SRAT Vessel Volume, L & 4 & 4 & 4 & 4 & 4 & 4 & 4 & \\
\hline \multicolumn{9}{|c|}{ Table A-1a -- Sludge Analyses for Acid Calculations } \\
\hline $\begin{array}{l}\text { Fresh Sludge Mass } \\
\text { without trim } \\
\text { chemicals }\end{array}$ & $3,153.5$ & $3,152.2$ & $3,174.0$ & $3,202.8$ & $3,231.6$ & $3,230.4$ & $2,537.0$ & g slurry \\
\hline $\begin{array}{l}\text { Fresh Sludge Weight } \\
\% \text { Total Solids }\end{array}$ & 15.45 & 15.45 & 16.21 & 17.04 & 17.84 & 17.84 & 16.21 & wt $\%$ \\
\hline $\begin{array}{l}\text { Fresh Sludge Weight } \\
\% \text { Calcined Solids }\end{array}$ & 11.65 & 11.65 & 12.52 & 13.45 & 14.37 & 14.37 & 12.52 & $\mathrm{wt} \%$ \\
\hline $\begin{array}{l}\text { Fresh Sludge Weight } \\
\% \text { Insoluble Solids }\end{array}$ & 11.58 & 11.58 & 11.44 & 11.30 & 11.16 & 11.16 & 11.44 & wt $\%$ \\
\hline Fresh Sludge Density & 1.125 & 1.125 & 1.134 & 1.144 & 1.153 & 1.153 & 1.134 & $\mathrm{~kg} / \mathrm{L}$ slurry \\
\hline $\begin{array}{l}\text { Fresh Sludge } \\
\text { Supernate density }\end{array}$ & 1.036 & 1.036 & 1.043 & 1.051 & 1.058 & 1.058 & 1.043 & $\begin{array}{l}\mathrm{kg} / \mathrm{L} \\
\text { supernate }\end{array}$ \\
\hline Fresh Sludge Nitrite & 6,680 & 6,680 & 7,562 & 8,507 & 9,435 & 9,435 & 7,562 & $\mathrm{mg} / \mathrm{kg}$ slurry \\
\hline Fresh Sludge Nitrate & 4,895 & 4,895 & 5,150 & 5,422 & 5,690 & 5,690 & 5,150 & $\mathrm{mg} / \mathrm{kg}$ slurry \\
\hline Fresh Sludge Formate & 0 & 0 & 0 & 0 & & & 0 & $\mathrm{mg} / \mathrm{kg}$ slurry \\
\hline $\begin{array}{l}\text { Fresh Sludge Sulfate } \\
(\mathrm{mg} / \mathrm{kg})\end{array}$ & 323 & 323 & 319 & 316 & 312 & 312 & 319 & $\mathrm{mg} / \mathrm{kg}$ slurry \\
\hline $\begin{array}{l}\text { Fresh Sludge Chloride } \\
(\mathrm{mg} / \mathrm{kg})\end{array}$ & 352 & 352 & 239 & 118 & 0 & 0 & 239 & $\mathrm{mg} / \mathrm{kg}$ slurry \\
\hline $\begin{array}{l}\text { Fresh Sludge } \\
\text { Phosphate }(\mathrm{mg} / \mathrm{kg})\end{array}$ & 0 & 0 & 0 & 0 & 0 & 0 & 0 & $\mathrm{mg} / \mathrm{kg}$ slurry \\
\hline Fresh Sludge Oxalate & 140 & 140 & 95 & 47 & 0 & 0 & 95 & $\mathrm{mg} / \mathrm{kg}$ slurry \\
\hline $\begin{array}{l}\text { Fresh Sludge Slurry } \\
\text { TIC (treated as }\end{array}$ & 2,219 & 2,219 & 1,940 & 1,641 & 1,347 & 1,347 & 1,940 & $\mathrm{mg} / \mathrm{kg}$ slurry \\
\hline
\end{tabular}




\begin{tabular}{|c|c|c|c|c|c|c|c|c|}
\hline \multicolumn{9}{|c|}{ Table A-1. SRNL Acid, Trim Chemical, Dewater and Redox Calculations } \\
\hline Run \# & SB10-1 & SB10-2 & SB10-3 & SB10-5 & SB10-7 & SB10-8 & SB10-9 & Units \\
\hline \multicolumn{9}{|l|}{ carbonate) } \\
\hline $\begin{array}{l}\text { Fresh Supernate TIC } \\
\text { (treated as carbonate) }\end{array}$ & 1,719 & 1,719 & 1,539 & 1,345 & 1,151 & 1,151 & 1,539 & $\begin{array}{l}\mathrm{mg} / \mathrm{L} \\
\text { supernate }\end{array}$ \\
\hline $\begin{array}{l}\text { Fresh Sludge } \\
\text { Hydroxide (Base } \\
\text { Equivalents) } \mathrm{pH}=7\end{array}$ & 0.664 & 0.664 & 0.741 & 0.825 & 0.909 & 0.909 & 0.741 & $\begin{array}{l}\text { Equiv Moles } \\
\text { Base/L slurry }\end{array}$ \\
\hline $\begin{array}{l}\text { Fresh Sludge Coal- } \\
\text { carbon/Carbon source }\end{array}$ & 9.595 & 9.595 & 6.213 & 2.931 & 0.000 & 0.000 & 6.214 & wt $\%$ dry basis \\
\hline $\begin{array}{l}\text { Fresh Sludge } \\
\text { Manganese }(\% \text { of } \\
\text { Calcined Solids) }\end{array}$ & 5.825 & 5.825 & 5.652 & 5.492 & 5.355 & 5.355 & 5.652 & $\begin{array}{l}\text { wt } \% \text { calcined } \\
\text { basis }\end{array}$ \\
\hline $\begin{array}{l}\text { Fresh Sludge Mercury } \\
(\% \text { of Total Solids in } \\
\text { untrimmed sludge) }\end{array}$ & 0.0000 & 0.0000 & 0.0000 & 0.0000 & 0.0000 & 0.0000 & 0.0000 & wt $\%$ dry basis \\
\hline $\begin{array}{l}\text { Fresh Sludge } \\
\text { Magnesium ( } \% \text { of } \\
\text { Calcined Solids) }\end{array}$ & 0.367 & 0.367 & 0.353 & 0.340 & 0.330 & 0.330 & 0.353 & $\begin{array}{l}\text { wt } \% \text { calcined } \\
\text { basis }\end{array}$ \\
\hline $\begin{array}{l}\text { Fresh Sludge Sodium } \\
\text { (\% of Calcined Solids) }\end{array}$ & 13.600 & 13.600 & 14.021 & 14.410 & 14.745 & 14.745 & 14.021 & $\begin{array}{l}\text { wt } \% \text { calcined } \\
\text { basis }\end{array}$ \\
\hline $\begin{array}{l}\text { Fresh Sludge } \\
\text { Potassium (\% of } \\
\text { Calcined Solids) }\end{array}$ & 0.253 & 0.253 & 0.234 & 0.217 & 0.202 & 0.202 & 0.234 & $\begin{array}{l}\text { wt } \% \text { calcined } \\
\text { basis }\end{array}$ \\
\hline $\begin{array}{l}\text { Fresh Sludge Cesium } \\
\text { (\% of Calcined Solids) }\end{array}$ & 0.000 & 0.000 & 0.000 & 0.000 & 0.000 & 0.000 & 0.000 & $\begin{array}{l}\text { wt } \% \text { calcined } \\
\text { basis }\end{array}$ \\
\hline $\begin{array}{l}\text { Fresh Sludge Calcium } \\
\text { ( } \% \text { of Calcined Solids) }\end{array}$ & 2.915 & 2.915 & 2.762 & 2.620 & 2.499 & 2.499 & 2.762 & $\begin{array}{l}\text { wt } \% \text { calcined } \\
\text { basis }\end{array}$ \\
\hline $\begin{array}{l}\text { Fresh Sludge } \\
\text { Strontium (\% of } \\
\text { Calcined Solids) }\end{array}$ & 0.000 & 0.000 & 0.000 & 0.000 & 0.000 & 0.000 & 0.000 & $\begin{array}{l}\text { wt } \% \text { calcined } \\
\text { basis }\end{array}$ \\
\hline $\begin{array}{l}\text { Fresh Sludge Nickel } \\
\text { (\% of Calcined Solids) }\end{array}$ & 0.830 & 0.830 & 0.796 & 0.764 & 0.736 & 0.736 & 0.796 & $\begin{array}{l}\text { wt } \% \text { calcined } \\
\text { basis }\end{array}$ \\
\hline $\begin{array}{l}\text { Fresh Sludge } \\
\text { Supernate manganese }\end{array}$ & 0.000 & 0.000 & 0.000 & 0.000 & 0.000 & 0.000 & 0.000 & $\begin{array}{l}\mathrm{mg} / \mathrm{L} \\
\text { supernate }\end{array}$ \\
\hline
\end{tabular}




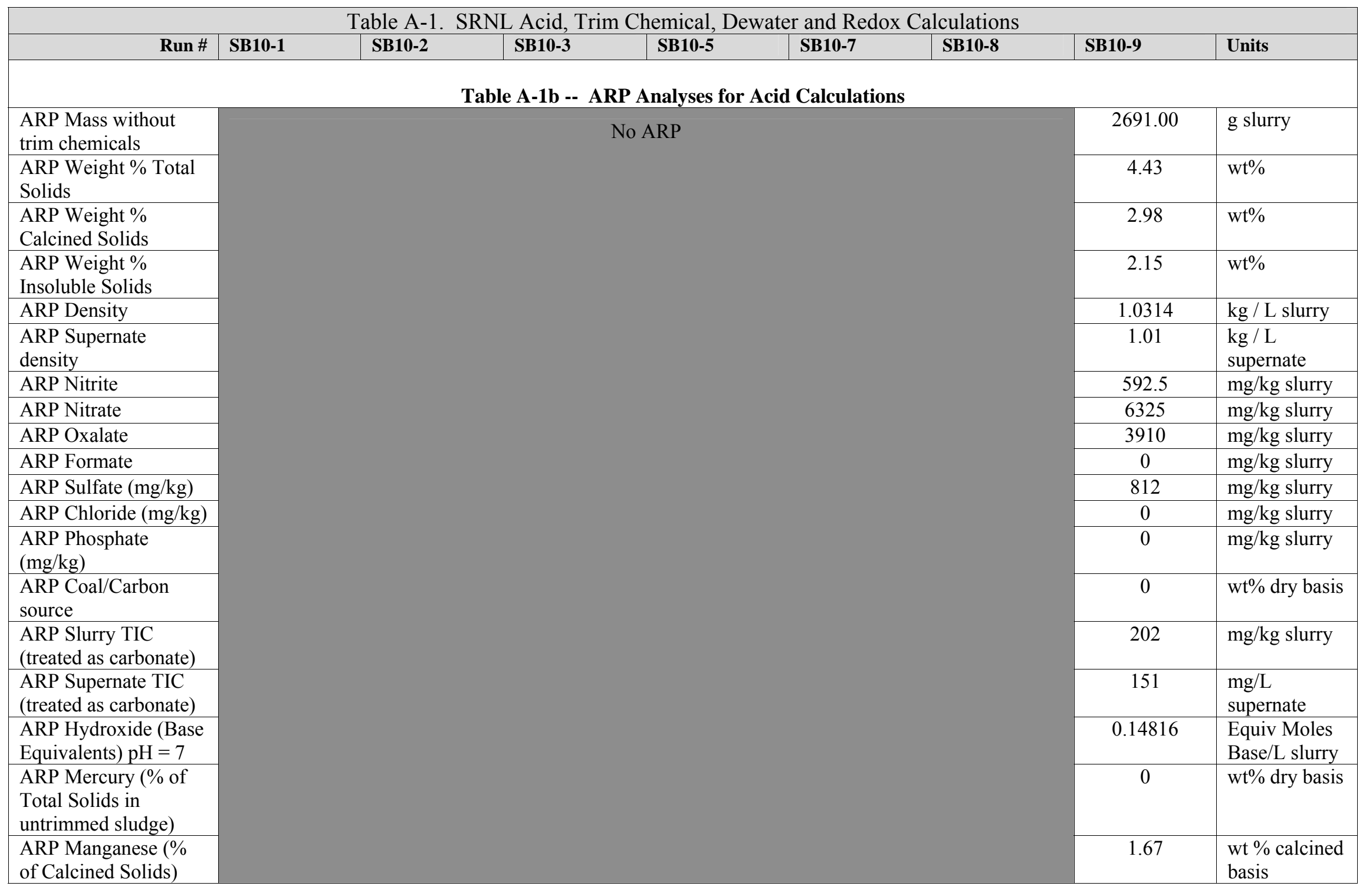




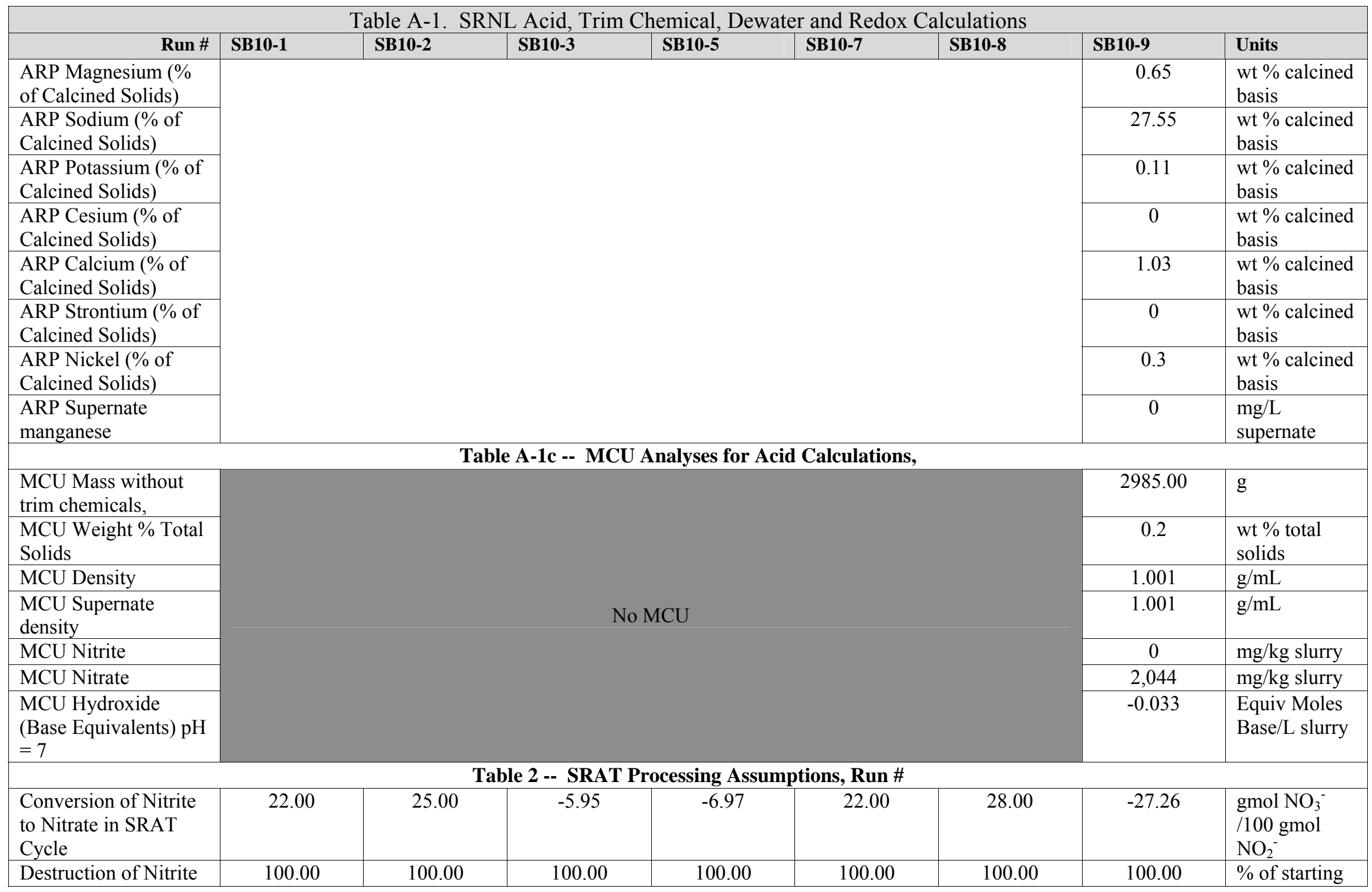




\begin{tabular}{|c|c|c|c|c|c|c|c|c|}
\hline \multicolumn{9}{|c|}{ Table A-1. SRNL Acid, Trim Chemical, Dewater and Redox Calculations } \\
\hline Run \# & SB10-1 & SB10-2 & SB10-3 & SB10-5 & SB10-7 & SB10-8 & SB10-9 & Units \\
\hline $\begin{array}{l}\text { in SRAT and SME } \\
\text { cycle }\end{array}$ & & & & & & & & $\begin{array}{l}\text { nitrite } \\
\text { destroyed }\end{array}$ \\
\hline $\begin{array}{l}\text { Destruction of Formic } \\
\text { acid charged in SRAT }\end{array}$ & 100.00 & 60.00 & 20.72 & 28.67 & 20.00 & 35.00 & 27.24 & $\begin{array}{l}\% \text { formate } \\
\text { converted to } \\
\mathrm{CO}_{2} \text { etc. }\end{array}$ \\
\hline $\begin{array}{l}\text { Destruction of Oxalate } \\
\text { charged }\end{array}$ & 50.00 & 50.00 & 50.00 & 50.00 & 50.00 & 50.00 & 50.00 & $\begin{array}{l}\% \text { of total } \\
\text { oxalate } \\
\text { destroyed }\end{array}$ \\
\hline $\begin{array}{l}\text { Percent Acid in } \\
\text { Excess Stoichiometric } \\
\text { Ratio }\end{array}$ & 96.78 & 150.00 & 100.00 & 100.00 & 100.00 & 150.00 & 150.00 & $\%$ \\
\hline $\begin{array}{l}\text { SRAT Product Target } \\
\text { Solids }\end{array}$ & 25.00 & 25.00 & 25.00 & 25.00 & 25.00 & 25.00 & 25.00 & $\%$ \\
\hline Nitric Acid Molarity & 10.534 & 10.600 & 10.400 & 10.400 & 10.600 & 10.534 & 10.400 & Molar \\
\hline Formic Acid Molarity & 23.800 & 23.800 & 23.840 & 23.840 & 23.800 & 23.800 & 23.840 & Molar \\
\hline $\begin{array}{l}\text { DWPF Nitric Acid } \\
\text { addition Rate }\end{array}$ & 2.0 & 2.0 & 2.0 & 2.0 & 2.0 & 2.0 & 2.0 & $\begin{array}{l}\text { gallons per } \\
\text { minute }\end{array}$ \\
\hline $\begin{array}{l}\text { DWPF Formic Acid } \\
\text { addition Rate }\end{array}$ & 2.0 & 2.0 & 2.0 & 2.0 & 2.0 & 2.0 & 2.0 & $\begin{array}{l}\text { gallons per } \\
\text { minute }\end{array}$ \\
\hline REDOX Target & 0.200 & 0.200 & 0.200 & 0.200 & 0.200 & 0.200 & 0.200 & $\mathrm{Fe}^{+2} / \Sigma \mathrm{Fe}$ \\
\hline $\begin{array}{l}\text { Trimmed Sludge } \\
\text { Target Ag metal } \\
\text { content }\end{array}$ & 0.0108 & 0.0108 & 0.0119 & 0.0130 & 0.0142 & 0.0142 & 0.0119 & $\begin{array}{l}\text { total wt } \% \text { dry } \\
\text { basis after } \\
\text { trim }\end{array}$ \\
\hline $\begin{array}{l}\text { Trimmed Sludge } \\
\text { Target } \mathrm{wt} \% \mathrm{Hg} \text { dry } \\
\text { basis }\end{array}$ & 1.2272 & 1.2272 & 1.3526 & 1.4868 & 1.6188 & 1.6188 & 1.3526 & $\begin{array}{l}\text { total } \mathrm{wt} \% \text { dry } \\
\text { basis after } \\
\text { trim }\end{array}$ \\
\hline $\begin{array}{l}\text { Trimmed Sludge } \\
\text { Target Pd metal } \\
\text { content }\end{array}$ & 0.0050 & 0.0050 & 0.0055 & 0.0061 & 0.0066 & 0.0066 & 0.0055 & $\begin{array}{l}\text { total } \mathrm{wt} \% \text { dry } \\
\text { basis after } \\
\text { trim }\end{array}$ \\
\hline $\begin{array}{l}\text { Trimmed Sludge } \\
\text { Target Rh metal } \\
\text { content }\end{array}$ & 0.0177 & 0.0177 & 0.0195 & 0.0214 & 0.0233 & 0.0233 & 0.0195 & $\begin{array}{l}\text { total } \mathrm{wt} \% \text { dry } \\
\text { basis after } \\
\text { trim }\end{array}$ \\
\hline $\begin{array}{l}\text { Trimmed Sludge } \\
\text { Target Ru metal }\end{array}$ & 0.0850 & 0.0850 & 0.0937 & 0.1030 & 0.1121 & 0.1121 & 0.0937 & $\begin{array}{l}\text { total } \mathrm{wt} \% \text { dry } \\
\text { basis after }\end{array}$ \\
\hline
\end{tabular}




\begin{tabular}{|c|c|c|c|c|c|c|c|c|}
\hline \multicolumn{9}{|c|}{ Table A-1. SRNL Acid, Trim Chemical, Dewater and Redox Calculations } \\
\hline Run \# & SB10-1 & SB10-2 & SB10-3 & SB10-5 & SB10-7 & SB10-8 & SB10-9 & Units \\
\hline content & & & & & & & & trim \\
\hline $\begin{array}{l}\text { Trimmed Sludge } \\
\text { Target Wt\% Coal- } \\
\text { carbon/carbon source } \\
\text { dry basis }\end{array}$ & 9.4406 & 9.4406 & 6.1032 & 2.8744 & 0.0000 & 0.0000 & 6.1036 & $\begin{array}{l}\text { total } \mathrm{wt} \% \text { dry } \\
\text { basis after } \\
\text { trim }\end{array}$ \\
\hline $\begin{array}{l}\text { Trimmed Sludge } \\
\text { Target oxalate after } \\
\text { trim (wt \% not } \mathrm{mg} / \mathrm{kg} \text { ) }\end{array}$ & 0.0892 & 0.0892 & 0.0576 & 0.0272 & 0.0000 & 0.0000 & 0.0447 & $\begin{array}{l}\text { total wt } \% \text { dry } \\
\text { basis after } \\
\text { trim }\end{array}$ \\
\hline $\begin{array}{l}\text { Water to dilute fresh } \\
\text { sludge and/or rinse } \\
\text { trim chemicals }\end{array}$ & 100.00 & 100.00 & 100.00 & 100.00 & 100.00 & 100.00 & 100.00 & $\mathrm{~g}$ \\
\hline $\begin{array}{l}\text { Mass of SRAT cycle } \\
\text { samples }\end{array}$ & 250.00 & 250.00 & 250.00 & 250.00 & 250.00 & 250.00 & 250.00 & $\mathrm{~g}$ \\
\hline $\begin{array}{l}\text { Wt } \% \text { Active Agent In } \\
\text { Antifoam Solution }\end{array}$ & 10 & 10 & 10 & 10 & 10 & 10 & 10 & $\%$ \\
\hline $\begin{array}{l}\text { Basis Antifoam } \\
\text { Addition for SRAT } \\
\text { (generally } 100 \mathrm{mg} \\
\text { antifoam/kg slurry) }\end{array}$ & 100 & 100 & 100 & 100 & 100 & 100 & 100 & $\mathrm{mg} / \mathrm{kg}$ slurry \\
\hline $\begin{array}{l}\text { Number of basis } \\
\text { antifoam additions } \\
\text { added during SRAT } \\
\text { cycle }\end{array}$ & 8 & 8 & 8 & 8 & 8 & 8 & 12 & \\
\hline SRAT air purge & 230 & 230 & 230 & 230 & 230 & 230 & 230 & scfm \\
\hline SRAT boil-up rate & 5000 & 5000 & 5000 & 5000 & 5000 & 5000 & 5000 & $\mathrm{lbs} / \mathrm{hr}$ \\
\hline $\begin{array}{l}\text { SRAT total boil-up } \\
\text { (reflux) }\end{array}$ & 60,000 & 60,000 & 60,000 & 60,000 & 60,000 & 60,000 & 60,000 & lbs \\
\hline $\begin{array}{l}\text { SRAT Steam } \\
\text { Stripping Factor }\end{array}$ & 750 & 750 & 750 & 750 & 750 & 750 & 750 & $\begin{array}{l}\text { (g steam/g } \\
\text { mercury) }\end{array}$ \\
\hline \multicolumn{9}{|c|}{ Table 3 -- SME Processing Assumptions } \\
\hline Frit type & 418 & 418 & 418 & 418 & 418 & 418 & 418 & \\
\hline $\begin{array}{l}\text { Destruction of Formic } \\
\text { acid in SME }\end{array}$ & 5.00 & 5.00 & 5.00 & 5.00 & 5.00 & 5.00 & 5.00 & $\begin{array}{l}\% \text { Formate } \\
\text { converted to } \\
\mathrm{CO}_{2} \text { etc. }\end{array}$ \\
\hline
\end{tabular}




\begin{tabular}{|c|c|c|c|c|c|c|c|c|}
\hline \multicolumn{9}{|c|}{ Table A-1. SRNL Acid, Trim Chemical, Dewater and Redox Calculations } \\
\hline Run \# & SB10-1 & SB10-2 & SB10-3 & SB10-5 & SB10-7 & SB10-8 & SB10-9 & Units \\
\hline $\begin{array}{l}\text { Destruction of Nitrate } \\
\text { in SME }\end{array}$ & 5.00 & 5.00 & 5.00 & 5.00 & 5.00 & 5.00 & 5.00 & $\begin{array}{l}\text { \% Nitrate } \\
\text { destroyed in } \\
\text { SME }\end{array}$ \\
\hline Assumed SME density & 1.450 & 1.450 & 1.450 & 1.450 & 1.450 & 1.450 & 1.450 & $\mathrm{~kg} / \mathrm{L}$ \\
\hline $\begin{array}{l}\text { Sludge Oxide } \\
\text { Contribution in SME } \\
\text { (Waste Loading) }\end{array}$ & 38.00 & 38.00 & 38.00 & 38.00 & 38.00 & 38.00 & 38.00 & $\%$ \\
\hline $\begin{array}{l}\text { Frit Slurry Formic } \\
\text { Acid Ratio }\end{array}$ & 1.50 & 1.50 & 1.50 & 1.50 & 1.50 & 1.50 & 1.50 & $\begin{array}{l}\text { g } 90 \mathrm{wt} \% \\
\text { FA/100 g Frit }\end{array}$ \\
\hline $\begin{array}{l}\text { Target SME Solids } \\
\text { total } \mathrm{Wt} \%\end{array}$ & 50.0 & 50.0 & 50.0 & 50.0 & 50.0 & 50.0 & 50.0 & $\mathrm{wt} \%$ \\
\hline $\begin{array}{l}\text { Number of frit } \\
\text { additions in SME } \\
\text { Cycle }\end{array}$ & 2 & 2 & 2 & 2 & 2 & 2 & 2 & \\
\hline $\begin{array}{l}\text { \# DWPF Canister } \\
\text { decons simulated }\end{array}$ & 0.0 & 0.0 & 0.0 & 0.0 & 0.0 & 0.0 & 0.0 & \\
\hline $\begin{array}{l}\text { Volume of water per } \\
\text { deconned can }\end{array}$ & 1,000 & 1,000 & 1,000 & 1,000 & 1,000 & 1,000 & 1,000 & $\begin{array}{l}\text { gal at DWPF } \\
\text { scale }\end{array}$ \\
\hline $\begin{array}{l}\text { Water flush volume } \\
\text { after frit slurry } \\
\text { addition }\end{array}$ & 0.0 & 0.0 & 0.0 & 0.0 & 0.0 & 0.0 & 0.0 & gal \\
\hline SME air purge & 74 & 74 & 74 & 74 & 74 & 74 & 74 & scfm \\
\hline SME boil-up rate & 5000 & 5000 & 5000 & 5000 & 5000 & 5000 & 5000 & $\mathrm{lbs} / \mathrm{hr}$ \\
\hline \multicolumn{9}{|c|}{ Acid and Glass Calculation Base Values } \\
\hline Total nitrite & 0.458 & 0.458 & 0.522 & 0.592 & 0.663 & 0.663 & 0.452 & gmol \\
\hline $\begin{array}{l}\text { Total Mn minus } \\
\text { soluble Mn }\end{array}$ & 0.390 & 0.389 & 0.409 & 0.431 & 0.453 & 0.452 & 0.351 & gmol \\
\hline Total carbonate & 0.583 & 0.582 & 0.513 & 0.438 & 0.362 & 0.362 & 0.455 & gmol \\
\hline Total hydroxide & 1.861 & 1.860 & 2.075 & 2.311 & 2.548 & 2.547 & 1.947 & gmol \\
\hline Total mercury & 0.030 & 0.030 & 0.035 & 0.040 & 0.047 & 0.047 & 0.028 & gmol \\
\hline Total oxalate & 0.005 & 0.005 & 0.003 & 0.002 & 0.000 & 0.000 & 0.122 & gmol \\
\hline $\begin{array}{l}\text { Total grams of } \\
\text { calcined oxides }\end{array}$ & 367.465 & 367.314 & 397.471 & 430.905 & 464.364 & 464.191 & 397.891 & $\mathrm{~g}$ \\
\hline Trim Chemicals & 7.9623 & 7.9590 & 9.2829 & 10.8328 & 12.4809 & 12.4762 & 9.5685 & \\
\hline
\end{tabular}




\begin{tabular}{|c|c|c|c|c|c|c|c|c|}
\hline \multicolumn{9}{|c|}{ Table A-1. SRNL Acid, Trim Chemical, Dewater and Redox Calculations } \\
\hline Run \# & SB10-1 & SB10-2 & SB10-3 & SB10-5 & SB10-7 & SB10-8 & SB10-9 & Units \\
\hline \multicolumn{9}{|l|}{ Calculations } \\
\hline $\begin{array}{l}\text { Fresh Sludge Calcine } \\
\text { Factor }\left(1100^{\circ} \mathrm{C}\right), \mathrm{g} \\
\text { oxide/g dry solids } \\
\text { (calculated) }\end{array}$ & 0.7543 & 0.7543 & 0.7723 & 0.7897 & 0.8053 & 0.8053 & 0.7723 & $\mathrm{~g} / \mathrm{g}$ \\
\hline ARP calcine factor & 0.0000 & 0.0000 & 0.0000 & 0.0000 & 0.0000 & 0.0000 & 0.6727 & $\mathrm{~g} / \mathrm{g}$ \\
\hline $\begin{array}{l}\text { Total solids before } \\
\text { trim addition }\end{array}$ & 487.1300 & 486.9291 & 514.6610 & 545.6458 & 576.6522 & 576.4380 & 530.5815 & $\mathrm{~g}$ \\
\hline $\begin{array}{l}\text { Total solids before } \\
\text { trim less } \mathrm{HgO} \text {, } \\
\text { NaOxalate, coal- } \\
\text { carbon) }\end{array}$ & 439.73 & 439.55 & 482.23 & 529.42 & 576.65 & 576.44 & 497.25 & $\mathrm{~g}$ \\
\hline $\begin{array}{l}\text { Predicted total solids } \\
\text { at target levels }\end{array}$ & 495.0923 & 494.8882 & 523.9439 & 556.4786 & 589.1330 & 588.9143 & 540.1500 & $\mathrm{~g}$ \\
\hline $\begin{array}{l}\text { Predicted total mass at } \\
\text { target levels }\end{array}$ & $3,261.4623$ & $3,261.7956$ & $3,285.1926$ & $3,315.8625$ & $3,346.6510$ & $3,345.4454$ & $5,339.3161$ & $\mathrm{~g}$ \\
\hline $\begin{array}{l}\text { Target Ag metal } \\
\text { content in trimmed } \\
\text { sludge }\end{array}$ & 0.010765 & 0.010765 & 0.011865 & 0.013043 & 0.014200 & 0.014200 & 0.011865 & $\begin{array}{l}\text { total } \mathrm{wt} \% \text { dry } \\
\text { basis }\end{array}$ \\
\hline $\begin{array}{l}\mathrm{AgNO}_{3} \text { to add } \\
(\mathrm{CF}=0.682)\end{array}$ & 0.00000 & 0.08390 & 0.09790 & 0.11430 & 0.13174 & 0.13170 & 0.08959 & $\mathrm{~g}$ \\
\hline Ag2O calcined solids & 0.00000 & 0.05723 & 0.06678 & 0.07796 & 0.08986 & 0.08983 & 0.06111 & $\mathrm{~g}$ \\
\hline Water added with Ag & 0.00000 & 0.00000 & 0.00000 & 0.00000 & 0.00000 & 0.00000 & 0.00000 & $\mathrm{~g}$ \\
\hline $\begin{array}{l}\text { Target } \mathrm{wt} \% \mathrm{Hg} \text { dry } \\
\text { basis }\end{array}$ & 1.227 & 1.227 & 1.353 & 1.487 & 1.619 & 1.619 & 1.353 & $\begin{array}{l}\text { total } \mathrm{wt} \% \text { dry } \\
\text { basis }\end{array}$ \\
\hline $\begin{array}{l}\text { Total } \mathrm{HgO} \text { in fresh } \\
\text { Sludge }\end{array}$ & 0.000 & 0.000 & 0.000 & 0.000 & 0.000 & 0.000 & 0.000 & $\mathrm{~g}$ \\
\hline $\begin{array}{l}\text { Total } \mathrm{HgO} \text { in trimmed } \\
\text { Sludge }\end{array}$ & 6.56029 & 6.55758 & 7.65205 & 8.93374 & 10.29730 & 10.29348 & 7.88867 & $\mathrm{~g}$ \\
\hline $\mathrm{HgO}$ to add & 0.00000 & 6.55758 & 7.65205 & 8.93374 & 10.29730 & 10.29348 & 7.00246 & $\mathrm{~g}$ \\
\hline HgO calcined solids & 0.00000 & 0.00000 & 0.00000 & 0.00000 & 0.00000 & 0.00000 & 0.00000 & $\mathrm{~g}$ \\
\hline Water added with $\mathrm{Hg}$ & 0.00000 & 0.00000 & 0.00000 & 0.00000 & 0.00000 & 0.00000 & 0.00000 & $\mathrm{~g}$ \\
\hline Calculated total $\mathrm{wt} \%$ & 0.0000 & 1.2272 & 1.3526 & 1.4868 & 1.6188 & 1.6188 & 1.2006 & $\mathrm{wt} \%$ dry basis \\
\hline
\end{tabular}


SRNL-STI-2010-00589

Revision 0

\begin{tabular}{|c|c|c|c|c|c|c|c|c|}
\hline \multicolumn{9}{|c|}{ Table A-1. SRNL Acid, Trim Chemical, Dewater and Redox Calculations } \\
\hline Run \# & SB10-1 & SB10-2 & SB10-3 & SB10-5 & SB10-7 & SB10-8 & SB10-9 & Units \\
\hline \multicolumn{9}{|l|}{ Hg dry basis } \\
\hline $\begin{array}{l}\text { Target Pd metal } \\
\text { content in trimmed } \\
\text { sludge }\end{array}$ & 0.0050 & 0.0050 & 0.0055 & 0.0061 & 0.0066 & 0.0066 & 0.0055 & $\begin{array}{l}\text { total } w t \% \text { dry } \\
\text { basis }\end{array}$ \\
\hline $\begin{array}{l}\mathrm{Wt} \% \mathrm{Pd} \text { in reagent } \\
\text { solution }\end{array}$ & 15.2700 & 15.2700 & 15.2700 & 15.2700 & 15.2700 & 15.2700 & 15.2700 & $\begin{array}{l}\mathrm{wt} \% \text { in } \\
\text { solution }\end{array}$ \\
\hline $\begin{array}{l}\mathrm{Pd}\left(\mathrm{NO}_{3}\right)_{2} * \mathrm{H}_{2} \mathrm{O} \\
\text { solution to add } \\
(\mathrm{CF}=1.150 \text { g metal } \\
\text { oxide/g metal })\end{array}$ & 0.00000 & 0.16216 & 0.18922 & 0.22092 & 0.25464 & 0.25454 & 0.17316 & $\mathrm{~g}$ of solution \\
\hline $\mathrm{Pd}(\mathrm{NO} 3) 2$ to add & 0.00000 & 0.05362 & 0.06256 & 0.07304 & 0.08419 & 0.08416 & 0.05725 & $\mathrm{~g}$ \\
\hline PdO calcined solids & 0.00000 & 0.02848 & 0.03324 & 0.03881 & 0.04473 & 0.04471 & 0.03042 & $\mathrm{~g}$ \\
\hline Water added with $\mathrm{Pd}$ & 0.000 & 0.109 & 0.127 & 0.148 & 0.170 & 0.170 & 0.116 & $\mathrm{~g}$ \\
\hline $\begin{array}{l}\text { Target Rh metal } \\
\text { content in trimmed } \\
\text { sludge }\end{array}$ & 0.0177 & 0.0177 & 0.0195 & 0.0214 & 0.0233 & 0.0233 & 0.0195 & $\begin{array}{l}\text { total } \mathrm{wt} \% \text { dry } \\
\text { basis }\end{array}$ \\
\hline $\begin{array}{l}\mathrm{Wt} \% \mathrm{Rh} \text { in reagent } \\
\text { solution }\end{array}$ & 4.93 & 4.93 & 4.93 & 4.93 & 4.93 & 4.93 & 4.93 & $\begin{array}{l}\mathrm{wt}^{\%} \% \text { in } \\
\text { solution }\end{array}$ \\
\hline $\begin{array}{l}\mathrm{Rh}\left(\mathrm{NO}_{3}\right)_{3} * 2 \mathrm{H}_{2} \mathrm{O} \\
(\mathrm{CF}=1.311 \mathrm{~g} \text { metal } \\
\text { oxide/g metal })\end{array}$ & 0.0000 & 1.7731 & 2.0691 & 2.4156 & 2.7843 & 2.7833 & 1.8934 & $\mathrm{~g}$ of solution \\
\hline $\mathrm{Rh}(\mathrm{NO} 3) 3$ to add & 0.00000 & 0.24543 & 0.28639 & 0.33436 & 0.38540 & 0.38525 & 0.26208 & $\mathrm{~g}$ \\
\hline Rh2O3 calcined solids & 0.00000 & 0.10780 & 0.12579 & 0.14686 & 0.16928 & 0.16922 & 0.11512 & $\mathrm{~g}$ \\
\hline Water added with $\mathrm{Rh}$ & 0.000 & 1.528 & 1.783 & 2.081 & 2.399 & 2.398 & 1.631 & $\mathrm{~g}$ \\
\hline $\begin{array}{l}\text { Target Ru metal } \\
\text { content in trimmed } \\
\text { sludge }\end{array}$ & 0.0850 & 0.0850 & 0.0937 & 0.1030 & 0.1121 & 0.1121 & 0.0937 & $\begin{array}{l}\text { total } \mathrm{wt} \% \text { dry } \\
\text { basis }\end{array}$ \\
\hline $\begin{array}{l}\mathrm{Wt} \% \mathrm{Ru} \text { in } \mathrm{RuCl}_{3} \\
\text { reagent solids }\end{array}$ & 41.74 & 41.74 & 41.74 & 41.74 & 41.74 & 41.74 & 41.74 & $\mathrm{wt} \%$ in solids \\
\hline $\mathrm{RuCl}_{3}$ to add $(\mathrm{CF}=1.0)$ & 0.0000 & 1.0076 & 1.1758 & 1.3727 & 1.5822 & 1.5816 & 1.0760 & g solid \\
\hline $\begin{array}{l}\text { Target wt } \% \text { Coal- } \\
\text { carbon/carbon source } \\
\text { in trimmed sludge, dry } \\
\text { basis }\end{array}$ & 9.44 & 9.44 & 6.10 & 2.87 & 0.00 & 0.00 & 6.10 & $\begin{array}{l}\text { total } \mathrm{wt} \% \text { dry } \\
\text { basis }\end{array}$ \\
\hline
\end{tabular}




\begin{tabular}{|c|c|c|c|c|c|c|c|c|}
\hline \multicolumn{9}{|c|}{ Table A-1. SRNL Acid, Trim Chemical, Dewater and Redox Calculations } \\
\hline Run \# & SB10-1 & SB10-2 & SB10-3 & SB10-5 & SB10-7 & SB10-8 & SB10-9 & Units \\
\hline $\begin{array}{l}\text { Total Coal-carbon in } \\
\text { fresh Sludge }\end{array}$ & 46.740 & 46.720 & 31.977 & 15.995 & 0.000 & 0.000 & 25.561 & $\mathrm{~g}$ \\
\hline $\begin{array}{l}\text { Total Coal-carbon in } \\
\text { trimmed Sludge }\end{array}$ & 46.739 & 46.720 & 31.977 & 15.995 & 0.000 & 0.000 & 32.969 & $\mathrm{~g}$ \\
\hline $\begin{array}{l}\text { Mass of Coal to add } \\
(\mathrm{CF}=.08)\end{array}$ & 0.00 & 0.00 & 0.00 & 0.00 & 0.00 & 0.00 & 0.00 & $\mathrm{~g}$ \\
\hline $\begin{array}{l}\text { Calculated wt } \% \text { coal } \\
\text { after trim additions }\end{array}$ & 9.44 & 9.44 & 6.10 & 2.87 & 0.00 & 0.00 & 6.10 & $\mathrm{wt} \%$ \\
\hline $\begin{array}{l}\text { Target sodium oxalate } \\
\text { in trimmed sludge per } \\
\text { gm total solids }\end{array}$ & 0.14 & 0.14 & 0.09 & 0.04 & 0.00 & 0.00 & 0.07 & $\begin{array}{l}\text { total } w t \% \text { dry } \\
\text { basis }\end{array}$ \\
\hline $\begin{array}{l}\text { Total Sodium Oxalate } \\
\text { in fresh Sludge }\end{array}$ & 0.672 & 0.672 & 0.460 & 0.230 & 0.000 & 0.000 & 0.368 & $\mathrm{~g}$ \\
\hline $\begin{array}{l}\text { Total Sodium Oxalate } \\
\text { in trimmed Sludge }\end{array}$ & 0.672 & 0.672 & 0.460 & 0.230 & 0.000 & 0.000 & 0.368 & $\mathrm{~g}$ \\
\hline $\begin{array}{l}\text { Sodium oxalate to add } \\
(\mathrm{CF}=0.463)\end{array}$ & -0.0000015 & -0.0000015 & 0.0000000 & -0.0000012 & 0.0000000 & 0.0000000 & -0.0000038 & $\mathrm{~g}$ \\
\hline $\begin{array}{l}\text { Calculated oxalate } \\
\text { conc. after trim } \\
\text { chemical additions }\end{array}$ & 0.14 & 0.14 & 0.09 & 0.04 & 0.00 & 0.00 & 0.07 & $\begin{array}{l}\text { total } w t \% \text { dry } \\
\text { basis }\end{array}$ \\
\hline $\begin{array}{l}\mathrm{Na} 2 \mathrm{O} \text { calcined solids } \\
\text { from sodium oxalate }\end{array}$ & 0.31088 & 0.31075 & 0.21269 & 0.10639 & 0.00000 & 0.00000 & 0.17001 & \\
\hline $\begin{array}{l}\text { Total mass of trim } \\
\text { chemicals added }\end{array}$ & 0.0 & 9.6 & 11.2 & 13.1 & 15.1 & 15.0 & 10.2 & $\mathrm{~g}$ \\
\hline $\begin{array}{l}\text { Calcined oxides added } \\
\text { in trim chemicals }\end{array}$ & 0.00 & 1.20 & 1.40 & 1.64 & 1.89 & 1.89 & 1.28 & $\mathrm{~g}$ \\
\hline $\begin{array}{l}\text { Total solids after trim } \\
\text { addition }\end{array}$ & 487.13 & 494.88 & 523.94 & 556.47 & 589.13 & 588.91 & 539.07 & $\mathrm{~g}$ \\
\hline $\begin{array}{l}\text { Match of actual to } \\
\text { predicted total solids } \\
\text { mass }\end{array}$ & $101.61 \%$ & $100.00 \%$ & $100.00 \%$ & $100.00 \%$ & $100.00 \%$ & $100.00 \%$ & $100.20 \%$ & \\
\hline $\begin{array}{l}\text { Total Calcined solids } \\
\text { after trim }\end{array}$ & 367.47 & 368.51 & 398.87 & 432.54 & 466.25 & 466.08 & 399.17 & $\mathrm{~g}$ \\
\hline
\end{tabular}




\begin{tabular}{|c|c|c|c|c|c|c|c|c|}
\hline \multicolumn{9}{|c|}{ Table A-1. SRNL Acid, Trim Chemical, Dewater and Redox Calculations } \\
\hline Run \# & SB10-1 & SB10-2 & SB10-3 & SB10-5 & SB10-7 & SB10-8 & SB10-9 & Units \\
\hline $\begin{array}{l}\text { Water added to dilute } \\
\text { and/or rinse trim } \\
\text { chemicals }\end{array}$ & 100.0 & 100.0 & 100.0 & 100.0 & 100.0 & 100.0 & 100.0 & $\mathrm{~g}$ \\
\hline $\begin{array}{l}\text { Mass of trimmed } \\
\text { sludge }\end{array}$ & $3,253.50$ & $3,261.78$ & $3,285.18$ & $3,315.86$ & $3,346.65$ & $3,345.44$ & $5,338.23$ & $\mathrm{~g}$ \\
\hline $\begin{array}{l}\text { Calculated } w t \% \text { total } \\
\text { solids in SRAT receipt } \\
\text { sludge }\end{array}$ & 15.4 & 15.4 & 16.2 & 17.0 & 17.8 & 17.8 & 16.2 & $\mathrm{wt} \%$ \\
\hline $\begin{array}{l}\text { Sample mass of } \\
\text { trimmed sludge }\end{array}$ & 0.00 & 0.00 & 0.00 & 0.00 & 0.00 & 0.00 & 0.00 & $\mathrm{~g}$ \\
\hline $\begin{array}{l}\text { Mass of trimmed } \\
\text { feeds reacted }\end{array}$ & $3,253.50$ & $3,261.78$ & $3,285.18$ & $3,315.86$ & $3,346.65$ & $3,345.44$ & $5,338.23$ & $\mathrm{~g}$ \\
\hline $\begin{array}{l}\text { Mass of equivalent } \\
\text { sludge w/o ARP }\end{array}$ & $3,153.50$ & $3,203.65$ & $3,231.20$ & $3,266.36$ & $3,301.54$ & $3,300.32$ & $3,324.54$ & $\begin{array}{l}\mathrm{g}, \text { used to } \\
\text { calculate } \\
\text { scaling } \\
\text { factors, etc. }\end{array}$ \\
\hline $\begin{array}{l}\text { Sample removal ratio } \\
\text { at start of ARP boil }\end{array}$ & 1.000 & 1.000 & 1.000 & 1.000 & 1.000 & 1.000 & 1.000 & \\
\hline $\begin{array}{l}\text { Sample removal ratio } \\
\text { at start of SRAT }\end{array}$ & 1.000 & 1.000 & 1.000 & 1.000 & 1.000 & 1.000 & 1.000 & \\
\hline $\begin{array}{l}\text { Calcined solids at start } \\
\text { of SRAT }\end{array}$ & 367.5 & 368.5 & 398.9 & 432.5 & 466.3 & 466.1 & 399.2 & $\mathrm{~g}$ \\
\hline \multicolumn{9}{|c|}{ STOICHIOMETRIC ACID CALCULATIONS } \\
\hline Fresh feed $\mathrm{NO}_{2}^{-}$ & 0.46 & 0.46 & 0.52 & 0.59 & 0.66 & 0.66 & 0.45 & gmol \\
\hline Fresh feed Manganese & 0.38962 & 0.38946 & 0.40892 & 0.43075 & 0.45259 & 0.45242 & 0.35123 & gmol \\
\hline $\begin{array}{l}\text { Fresh feed slurry } \\
\text { Carbonate }\end{array}$ & 0.5827 & 0.5824 & 0.5126 & 0.4376 & 0.3624 & 0.3623 & 0.4550 & gmol \\
\hline Fresh feed $\mathrm{OH}^{-}$ & 1.8610 & 1.8603 & 2.0748 & 2.3114 & 2.5482 & 2.5473 & 1.9465 & gmol \\
\hline Fresh feed $\mathrm{H}+$ & 0.0000 & 0.0000 & 0.0000 & 0.0000 & 0.0000 & 0.0000 & -0.0984 & gmol \\
\hline Total Sludge Mercury & 0.030289 & 0.030277 & 0.035330 & 0.041247 & 0.047543 & 0.047525 & 0.036422 & gmol \\
\hline $\begin{array}{l}\text { Acid requirement per } \\
\text { mole of Oxalate }\end{array}$ & 0.01 & 0.01 & 0.00 & 0.00 & 0.00 & 0.00 & 0.12 & gmol \\
\hline
\end{tabular}




\begin{tabular}{|c|c|c|c|c|c|c|c|c|}
\hline \multicolumn{9}{|c|}{ Table A-1. SRNL Acid, Trim Chemical, Dewater and Redox Calculations } \\
\hline Run \# & SB10-1 & SB10-2 & SB10-3 & SB10-5 & SB10-7 & SB10-8 & SB10-9 & Units \\
\hline $\begin{array}{l}\text { Fresh Feed Supernate } \\
\text { Carbonate }\end{array}$ & 0.38 & 0.38 & 0.35 & 0.30 & 0.26 & 0.26 & 0.31 & gmol \\
\hline Fresh Feed Calcium & 0.27 & 0.27 & 0.27 & 0.28 & 0.29 & 0.29 & 0.24 & gmol \\
\hline $\begin{array}{l}\text { Fresh Feed } \\
\text { Magnesium }\end{array}$ & 0.06 & 0.06 & 0.06 & 0.06 & 0.06 & 0.06 & 0.07 & gmol \\
\hline Fresh Feed Sodium & 2.17 & 2.17 & 2.42 & 2.70 & 2.98 & 2.98 & 2.90 & gmol \\
\hline Fresh Feed Potassium & 0.02 & 0.02 & 0.02 & 0.02 & 0.02 & 0.02 & 0.02 & gmol \\
\hline Fresh Feed Cesium & 0.00 & 0.00 & 0.00 & 0.00 & 0.00 & 0.00 & 0.00 & gmol \\
\hline Fresh Feed Strontium & 0.00 & 0.00 & 0.00 & 0.00 & 0.00 & 0.00 & 0.00 & gmol \\
\hline Fresh Feed Nickel & 0.05 & 0.05 & 0.05 & 0.06 & 0.06 & 0.06 & 0.05 & gmol \\
\hline Fresh Feed Nitrate & 0.25 & 0.25 & 0.26 & 0.28 & 0.30 & 0.30 & 0.49 & gmol \\
\hline Fresh Feed Sulfate & 0.01 & 0.01 & 0.01 & 0.01 & 0.01 & 0.01 & 0.03 & gmol \\
\hline Fresh Feed Chloride & 0.03 & 0.03 & 0.02 & 0.01 & 0.00 & 0.00 & 0.02 & gmol \\
\hline Fresh Feed Formate & 0.00 & 0.00 & 0.00 & 0.00 & 0.00 & 0.00 & 0.00 & gmol \\
\hline Fresh Feed Phosphate & 0.00 & 0.00 & 0.00 & 0.00 & 0.00 & 0.00 & 0.00 & gmol \\
\hline $\begin{array}{l}\text { Hsu Total } \\
\text { Stoichiometric Acid } \\
\text { required }\end{array}$ & 3.8676 & 3.8660 & 4.0174 & 4.1889 & 4.3608 & 4.3592 & 3.6532 & gmol \\
\hline $\begin{array}{l}\text { Koopman Nominal } \\
\text { Stoichiometric Acid } \\
\text { required }\end{array}$ & 4.5135 & 4.5117 & 4.8365 & 5.1977 & 5.5594 & 5.5573 & 4.3798 & gmol \\
\hline $\begin{array}{l}\text { Koopman Minimum } \\
\text { Stoichiometric Acid } \\
\text { required }\end{array}$ & 3.8026 & 3.8011 & 4.0880 & 4.4068 & 4.7261 & 4.7243 & 3.7310 & gmol \\
\hline $\begin{array}{l}\text { Cation Nominal } \\
\text { Stoichiometric Acid } \\
\text { required }\end{array}$ & 3.7406 & 3.7391 & 4.0671 & 4.4307 & 4.7950 & 4.7932 & 4.0595 & gmol \\
\hline $\begin{array}{l}\text { Cation Minimum } \\
\text { Stoichiometric Acid } \\
\text { required }\end{array}$ & 3.1562 & 3.1549 & 3.4537 & 3.7846 & 4.1161 & 4.1146 & 3.5327 & gmol \\
\hline $\begin{array}{l}\text { Percent Acid in } \\
\text { Excess Stoichiometric } \\
\text { Ratio }\end{array}$ & 96.780 & 150.000 & 100.000 & 100.000 & 100.000 & 150.000 & 150.000 & $\%$ \\
\hline
\end{tabular}


SRNL-STI-2010-00589

Revision 0

\begin{tabular}{|l|c|c|c|c|c|c|c|c|}
\hline \multicolumn{7}{|c|}{ Table A-1. SRNL Acid, Trim Chemical, Dewater and Redox Calculations } \\
\hline \multicolumn{1}{|c|}{ Run \# } & SB10-1 & SB10-2 & SB10-3 & SB10-5 & SB10-7 & SB10-8 & SB10-9 & Units \\
\hline $\begin{array}{l}\text { Actual acid to add to } \\
\text { SRAT }\end{array}$ & 3.6802 & 5.7016 & 4.0880 & 4.4068 & 4.7261 & 7.0865 & 5.5964 & gmol \\
\hline $\begin{array}{l}\text { Acid required in } \\
\text { moles per liter of } \\
\text { starting sludge } \\
\text { (untrimmed, less } \\
\text { receipt samples) }\end{array}$ & 1.3129 & 2.0349 & 1.4604 & 1.5735 & 1.6867 & 2.5300 & 2.5013 & gmol/L \\
\hline
\end{tabular}


SRNL-STI-2010-00589

Revision 0

Appendix B: Analytical Results from Experiments 
Table B-1. Analytical Results for SRAT Product and SME Product Filtered Slurries

\begin{tabular}{|c|c|c|c|c|c|c|c|c|c|}
\hline \multicolumn{10}{|c|}{ Process Science Analytical Laboratory } \\
\hline \multicolumn{10}{|c|}{ Date: $7 / 12 / 10$} \\
\hline \multicolumn{10}{|c|}{ ICP-AES elemental supernate (mg/L) } \\
\hline Sample ID & Lab ID & Ag & $\underline{\text { Al }}$ & $\underline{\text { Ba }}$ & Ca & Cd & $\underline{\mathrm{Cr}}$ & Cu & Fe \\
\hline 10-SB10-1-3566 (A) & $10-0793$ & $<0.100$ & 3.39 & 128 & 3270 & $<0.010$ & 0.354 & 1.68 & $<0.010$ \\
\hline 10-SB10-1-3566 (B) & $10-0793$ & $<0.100$ & 2.67 & 128 & 3270 & $<0.010$ & 0.391 & 1.63 & $<0.010$ \\
\hline 10-SB10-1-3570 (A) & $10-0794$ & $<0.100$ & 2.09 & 132 & 5460 & $<0.010$ & 0.261 & 2.18 & $<0.010$ \\
\hline 10-SB10-1-3570 (B) & $10-0794$ & $<0.100$ & 2.07 & 131 & 5380 & $<0.010$ & 0.381 & 2.20 & $<0.010$ \\
\hline 10-SB10-2-3588 (A) & $10-0797$ & $<0.100$ & 543 & 197 & 3180 & $<0.010$ & 5.52 & 42.7 & 510 \\
\hline 10-SB10-2-3588 (B) & $10-0797$ & $<0.100$ & 536 & 203 & 3200 & $<0.010$ & 5.40 & 41.9 & 532 \\
\hline 10-SB10-2-3592 (A) & $10-0798$ & $<0.100$ & 30.3 & 178 & 4860 & 0.958 & 0.501 & 9.60 & 4850 \\
\hline 10-SB10-2-3592 (B) & $10-0798$ & $<0.100$ & 30.5 & 176 & 4830 & 1.01 & 0.654 & 9.51 & 4780 \\
\hline 10-SB10-3-3837 (A) & $10-0912$ & $<0.100$ & 4.88 & 126 & 3383 & $<0.010$ & 0.383 & NM & $<0.010$ \\
\hline 10-SB10-3-3837 (B) & $10-0912$ & $<0.100$ & 4.92 & 130 & 3426 & $<0.010$ & 0.470 & NM & $<0.010$ \\
\hline 10-SB10-3-3841 (A) & $10-0913$ & $<0.100$ & 2.00 & 111 & 5174 & $<0.010$ & 0.295 & NM & $<0.010$ \\
\hline 10-SB10-3-3841 (B) & $10-0913$ & $<0.100$ & 1.97 & 111 & 5189 & $<0.010$ & 0.192 & NM & $<0.010$ \\
\hline 10-SB10-5-3859 (A) & $10-0914$ & $<0.100$ & 4.10 & 70.4 & 3663 & $<0.010$ & 0.160 & NM & $<0.010$ \\
\hline 10-SB10-5-3859 (B) & $10-0914$ & $<0.100$ & 4.22 & 71.1 & 3648 & $<0.010$ & 0.270 & NM & $<0.010$ \\
\hline 10-SB10-5-3863 (A) & $10-0915$ & $<0.100$ & 2.03 & 41.5 & 4808 & $<0.010$ & $<0.010$ & NM & $<0.010$ \\
\hline 10-SB10-5-3863 (B) & $10-0915$ & $<0.100$ & 1.93 & 41.1 & 4784 & $<0.010$ & $<0.010$ & NM & $<0.010$ \\
\hline 10-SB10-7-3611 (A) & $10-0795$ & $<0.100$ & 1.81 & $<0.010$ & 3880 & $<0.010$ & $<0.010$ & 0.940 & $<0.010$ \\
\hline 10-SB10-7-3611 (B) & $10-0795$ & $<0.100$ & 1.81 & $<0.010$ & 3890 & $<0.010$ & $<0.010$ & 0.936 & $<0.010$ \\
\hline 10-SB10-7-3615 (A) & $10-0796$ & $<0.100$ & 1.96 & 30.4 & 4710 & $<0.010$ & $<0.010$ & 1.05 & $<0.010$ \\
\hline 10-SB10-7-3615 (B) & $10-0796$ & $<0.100$ & 1.84 & 30.4 & 4590 & $<0.010$ & $<0.010$ & 1.06 & $<0.010$ \\
\hline 10-SB10-8-3632 (A) & $10-0799$ & $<0.100$ & 192 & 78.5 & 3830 & $<0.010$ & 5.85 & 43.6 & 17.4 \\
\hline 10-SB10-8-3632 (B) & $10-0799$ & $<0.100$ & 186 & 77.9 & 3910 & $<0.010$ & 5.75 & 43.5 & 17.4 \\
\hline 10-SB10-8-3637 (A) & $10-0800$ & $<0.100$ & 2.61 & 82.0 & 5060 & $<0.010$ & 0.461 & 1.26 & 235 \\
\hline 10-SB10-8-3637 (B) & $10-0800$ & $<0.100$ & 2.39 & 81.6 & 5270 & $<0.010$ & 0.430 & 1.22 & 236 \\
\hline 10-SB10-9-3815 (A) & $10-0916$ & $<0.100$ & 169 & 7.62 & 2322 & $<0.010$ & 4.66 & NM & 34.4 \\
\hline 10-SB10-9-3815 (B) & $10-0916$ & $<0.100$ & 164 & 7.63 & 2345 & $<0.010$ & 4.56 & $\mathrm{NM}$ & 35.0 \\
\hline 10-SB10-9-3819 (A) & $10-0917$ & $<0.100$ & 125 & 7.75 & 2388 & $<0.010$ & 4.08 & NM & 751 \\
\hline 10-SB10-9-3819 (B) & $10-0917$ & $<0.100$ & 126 & 7.59 & 2339 & $<0.010$ & 4.00 & NM & 762 \\
\hline
\end{tabular}




\begin{tabular}{|c|c|c|c|c|c|c|c|c|}
\hline Sample ID & Lab ID & $\underline{\mathrm{K}}$ & $\mathrm{Mg}$ & $\mathrm{Mn}$ & $\mathrm{Ni}$ & $\underline{\mathrm{P}}$ & $\underline{\mathrm{Pb}}$ & $\underline{P d}$ \\
\hline 10-SB10-1-3566 (A) & $10-0793$ & 424 & 287 & 4620 & 90.0 & $<1.00$ & $<0.010$ & $<1.00$ \\
\hline 10-SB10-1-3566 (B) & $10-0793$ & 423 & 290 & 4620 & 92.1 & $<1.00$ & $<0.010$ & $<1.00$ \\
\hline 10-SB10-1-3570 (A) & $10-0794$ & 896 & 525 & 4610 & 3.29 & $<1.00$ & 0.185 & $<1.00$ \\
\hline 10-SB10-1-3570 (B) & $10-0794$ & 867 & 526 & 4560 & 3.42 & $<1.00$ & $<0.010$ & $<1.00$ \\
\hline 10-SB10-2-3588 (A) & $10-0797$ & 448 & 331 & 7240 & 494 & $<1.00$ & 11.1 & $<1.00$ \\
\hline 10-SB10-2-3588 (B) & $10-0797$ & 438 & 342 & 7280 & 496 & $<1.00$ & 11.3 & $<1.00$ \\
\hline $10-\mathrm{SB} 10-2-3592(\mathrm{~A})$ & $10-0798$ & 780 & 586 & 10800 & 670 & $<1.00$ & 5.03 & $<1.00$ \\
\hline 10-SB10-2-3592 (B) & $10-0793$ & 782 & 576 & 10700 & 672 & $<1.00$ & 4.88 & $<1.00$ \\
\hline 10-SB10-3-3837 (A) & $10-0912$ & 451 & 299 & 4846 & 158 & $<1.00$ & $<0.010$ & 0.225 \\
\hline 10-SB10-3-3837 (B) & $10-0912$ & 464 & 307 & 5018 & 162 & $<1.00$ & $<0.010$ & 0.208 \\
\hline 10-SB10-3-3841 (A) & $10-0913$ & 994 & 520 & 4905 & 2.51 & $<1.00$ & $<0.010$ & 0.128 \\
\hline 10-SB10-3-3841 (B) & $10-0913$ & 1020 & 518 & 4811 & 2.47 & $<1.00$ & $<0.010$ & 0.138 \\
\hline $10-\mathrm{SB} 10-5-3859$ (A) & $10-0914$ & 457 & 329 & 3612 & 119 & $<1.00$ & $<0.010$ & 0.159 \\
\hline 10-SB10-5-3859 (B) & $10-0914$ & 458 & 336 & 3662 & 123 & $<1.00$ & $<0.010$ & 0.136 \\
\hline 10-SB10-5-3863 (A) & $10-0915$ & 860 & 480 & 1577 & 1.22 & $<1.00$ & $<0.010$ & 0.149 \\
\hline 10-SB10-5-3863 (B) & $10-0915$ & 856 & 484 & 1589 & 1.21 & $<1.00$ & $<0.010$ & 0.189 \\
\hline 10-SB10-7-3611 (A) & $10-0795$ & 501 & 380 & 3730 & $<0.010$ & $<1.00$ & $<0.010$ & $<1.00$ \\
\hline 10-SB10-7-3611 (B) & $10-0795$ & 505 & 387 & 3700 & $<0.010$ & $<1.00$ & $<0.010$ & $<1.00$ \\
\hline $10-\mathrm{SB} 10-7-3615$ (A) & $10-0796$ & 819 & 495 & 1180 & 1.04 & $<1.00$ & $<0.010$ & $<1.00$ \\
\hline 10-SB10-7-3615 (B) & $10-0796$ & 808 & 494 & 1180 & 1.13 & $<1.00$ & $<0.010$ & $<1.00$ \\
\hline 10-SB10-8-3632 (A) & $10-0799$ & 496 & 423 & 8640 & 487 & $<1.00$ & 3.56 & $<1.00$ \\
\hline 10-SB10-8-3632 (B) & $10-0799$ & 477 & 421 & 8730 & 476 & $<1.00$ & 3.28 & $<1.00$ \\
\hline 10-SB10-8-3637 (A) & $10-0800$ & 762 & 583 & 8380 & 54.5 & $<1.00$ & 0.803 & $<1.00$ \\
\hline 10-SB10-8-3637 (B) & $10-0800$ & 757 & 584 & 8440 & 54.6 & $<1.00$ & 1.25 & $<1.00$ \\
\hline 10-SB10-9-3815 (A) & $10-0916$ & 445 & 399 & 6546 & 283 & $<1.00$ & $<0.010$ & 0.144 \\
\hline 10-SB10-9-3815 (B) & $10-0916$ & 429 & 398 & 6497 & 282 & $<1.00$ & $<0.010$ & 0.140 \\
\hline 10-SB10-9-3819 (A) & $10-0917$ & 445 & 406 & 6715 & 319 & $<1.00$ & 0.988 & 0.125 \\
\hline 10-SB10-9-3819 (B) & $10-0917$ & 448 & 406 & 6548 & 320 & $<1.00$ & 0.771 & 0.096 \\
\hline
\end{tabular}




\begin{tabular}{|c|c|c|c|c|c|c|c|c|c|}
\hline Sample ID & Lab ID & $\underline{\operatorname{Pr}}$ & $\underline{\mathrm{Rh}}$ & $\underline{\mathrm{Ru}}$ & $\underline{\mathrm{S}}$ & $\underline{\mathrm{Si}}$ & $\underline{\mathrm{Ti}}$ & $\underline{\mathrm{Zn}}$ & $\underline{\mathrm{Zr}}$ \\
\hline 10-SB10-1-3566 (A) & $10-0793$ & 1.02 & 9.23 & $<1.00$ & 8.26 & 155 & $<0.010$ & $<0.010$ & 0.030 \\
\hline 10-SB10-1-3566 (B) & $10-0793$ & 0.967 & 9.01 & $<1.00$ & 13.8 & 159 & $<0.010$ & $<0.010$ & 0.017 \\
\hline 10-SB10-1-3570 (A) & $10-0794$ & 3.23 & 0.521 & $<1.00$ & 23.3 & 42.9 & $<0.010$ & $<0.010$ & 0.030 \\
\hline 10-SB10-1-3570 (B) & $10-0794$ & 3.29 & 0.512 & $<1.00$ & 24.6 & 42.1 & $<0.010$ & $<0.010$ & 0.020 \\
\hline $10-\mathrm{SB} 10-2-3588(\mathrm{~A})$ & $10-0797$ & 2.20 & 2.94 & 1.57 & 18.6 & 168 & $<0.010$ & 14.9 & 0.560 \\
\hline $10-S B 10-2-3588$ (B) & $10-0797$ & 2.22 & 2.94 & 1.59 & 21.8 & 166 & $<0.010$ & 14.4 & 0.581 \\
\hline 10-SB10-2-3592 (A) & $10-0798$ & 4.41 & 0.665 & $<1.00$ & 23.3 & 83.0 & $<0.010$ & 20.1 & 0.355 \\
\hline 10-SB10-2-3592 (B) & $10-0798$ & 4.47 & 0.625 & $<1.00$ & 32.0 & 83.8 & $<0.010$ & 20.1 & 0.379 \\
\hline $10-\mathrm{SB} 10-3-3837$ (A) & $10-0912$ & 1.17 & 14.2 & 0.210 & 20.8 & 73.1 & $<0.010$ & 0.308 & 0.036 \\
\hline 10-SB10-3-3837 (B) & $10-0912$ & 1.23 & 14.2 & 0.332 & 25.3 & 74.0 & $<0.010$ & 0.203 & 0.027 \\
\hline $10-$ SB10-3-3841 (A) & $10-0913$ & 2.98 & 0.494 & $<0.010$ & 31.8 & 32.4 & $<0.010$ & $<0.010$ & 0.025 \\
\hline 10-SB10-3-3841 (B) & $10-0913$ & 2.94 & 0.484 & $<0.010$ & 25.9 & 32.3 & $<0.010$ & $<0.010$ & 0.018 \\
\hline $10-\mathrm{SB} 10-5-3859$ (A) & $10-0914$ & 1.41 & 17.7 & 1.29 & 33.2 & 31.7 & $<0.010$ & $<0.010$ & 0.029 \\
\hline 10-SB10-5-3859 (B) & $10-0914$ & 1.37 & 18.1 & 0.976 & 33.8 & 32.0 & $<0.010$ & $<0.010$ & 0.023 \\
\hline $10-\mathrm{SB} 10-5-3863$ (A) & $10-0915$ & 2.59 & 0.667 & $<0.010$ & 41.8 & 19.6 & $<0.010$ & $<0.010$ & 0.023 \\
\hline $10-\mathrm{SB} 10-5-3863$ (B) & $10-0915$ & 2.63 & 0.660 & $<0.010$ & 33.7 & 19.4 & $<0.010$ & $<0.010$ & 0.023 \\
\hline $10-\mathrm{SB} 10-7-3611$ (A) & $10-0795$ & $<0.010$ & 0.447 & $<1.00$ & 0.912 & 0.603 & $<0.010$ & $<0.010$ & 0.008 \\
\hline 10-SB10-7-3611 (B) & $10-0795$ & $<0.010$ & 0.447 & $<1.00$ & 0.967 & 0.436 & $<0.010$ & $<0.010$ & 0.012 \\
\hline $10-\mathrm{SB} 10-7-3615$ (A) & $10-0796$ & 2.45 & 0.966 & $<1.00$ & 48.6 & 36.2 & $<0.010$ & $<0.010$ & 0.022 \\
\hline 10-SB10-7-3615 (B) & $10-0796$ & 2.54 & 0.954 & $<1.00$ & 50.4 & 36.4 & $<0.010$ & $<0.010$ & 0.017 \\
\hline $10-\mathrm{SB} 10-8-3632$ (A) & $10-0799$ & 2.05 & 32.5 & 21.7 & 32.6 & 25.4 & $<0.010$ & 13.9 & 0.170 \\
\hline $10-\mathrm{SB} 10-8-3632(\mathrm{~B})$ & $10-0799$ & 2.04 & 32.5 & 21.4 & 38.4 & 25.7 & $<0.010$ & 13.8 & 0.203 \\
\hline $10-\mathrm{SB} 10-8-3637$ (A) & $10-0800$ & 3.28 & 0.600 & $<1.00$ & 32.9 & 105 & $<0.010$ & 2.56 & 0.059 \\
\hline 10-SB10-8-3637 (B) & $10-0800$ & 3.28 & 0.604 & $<1.00$ & 32.8 & 107 & $<0.010$ & 2.58 & 0.060 \\
\hline 10-SB10-9-3815 (A) & $10-0916$ & 0.478 & 2.16 & 0.270 & 169 & 141 & 0.087 & 5.69 & 0.050 \\
\hline 10-SB10-9-3815 (B) & $10-0916$ & 0.457 & 2.13 & $<0.010$ & 160 & 140 & 0.086 & 5.61 & 0.046 \\
\hline 10-SB10-9-3819 (A) & $10-0917$ & 0.572 & 1.88 & $<0.010$ & 165 & 161 & 0.041 & 9.30 & 0.080 \\
\hline 10-SB10-9-3819 (B) & $10-0917$ & 0.571 & 1.85 & $<0.010$ & 166 & 155 & 0.040 & 8.99 & 0.073 \\
\hline
\end{tabular}




\begin{tabular}{|c|c|c|c|c|c|c|c|c|}
\hline \multicolumn{9}{|l|}{ Anions, mg/L } \\
\hline Sample ID & Lab ID & F & $\mathrm{Cl}$ & $\mathrm{NO} 2$ & $\mathrm{NO} 3$ & SO4 & $\mathrm{C} 2 \mathrm{O} 4$ & $\mathrm{HCO} 2$ \\
\hline 10-SB10-1-3566 (A) & $10-0793$ & $<100$ & 144 & 1610 & 56600 & $<100$ & $<100$ & 84500 \\
\hline 10-SB10-1-3566 (B) & $10-0793$ & $<100$ & 144 & 1640 & 58100 & $<100$ & $<100$ & 84800 \\
\hline 10-SB10-1-3570 (A) & $10-0794$ & $<100$ & 401 & $<100$ & 100000 & $<100$ & $<100$ & 11400 \\
\hline 10-SB10-1-3570 (B) & $10-0794$ & $<100$ & 401 & $<100$ & 102000 & $<100$ & $<100$ & 11300 \\
\hline 10-SB10-2-3588 (A) & $10-0797$ & $<100$ & 200 & $<100$ & 75300 & $<100$ & $<100$ & 40000 \\
\hline 10-SB10-2-3588 (B) & $10-0797$ & $<100$ & 200 & $<100$ & 74200 & $<100$ & $<100$ & 39600 \\
\hline 10-SB10-2-3592 (A) & $10-0798$ & $<100$ & 366 & $<100$ & 109000 & 377 & $<100$ & 41400 \\
\hline 10-SB10-2-3592 (B) & $10-0798$ & $<100$ & 366 & $<100$ & 109000 & 377 & $<100$ & 40000 \\
\hline 10-SB10-3-3837 (A) & $10-0912$ & $<100$ & 214 & 2060 & 57700 & $<1000$ & $<100$ & 17900 \\
\hline 10-SB10-3-3837 (B) & $10-0912$ & $<100$ & 214 & 2090 & 56200 & $<1000$ & $<100$ & 18200 \\
\hline 10-SB10-3-3841 (A) & $10-0913$ & $<100$ & 443 & $<100$ & 93600 & $<1000$ & $<100$ & 25100 \\
\hline 10-SB10-3-3841 (B) & $10-0913$ & $<100$ & 443 & $<100$ & 92100 & $<1000$ & $<100$ & 24900 \\
\hline 10-SB10-5-3859 (A) & $10-0914$ & $<100$ & 238 & 5230 & 38000 & $<1000$ & $<100$ & 33600 \\
\hline 10-SB10-5-3859 (B) & $10-0914$ & $<100$ & 238 & 5180 & 37500 & $<1000$ & $<100$ & 34200 \\
\hline $10-\mathrm{SB} 10-5-3863(\mathrm{~A})$ & $10-0915$ & $<100$ & 364 & 1030 & 57900 & $<1000$ & $<100$ & 49200 \\
\hline 10-SB10-5-3863 (B) & $10-0915$ & $<100$ & 364 & 1030 & 56100 & $<1000$ & $<100$ & 49100 \\
\hline $10-\mathrm{SB} 10-7-3611(\mathrm{~A})$ & $10-0795$ & $<100$ & 261 & 6440 & 20000 & $<100$ & $<100$ & 48500 \\
\hline 10-SB10-7-3611 (B) & $10-0795$ & $<100$ & 261 & 6420 & 21500 & $<100$ & $<100$ & 49400 \\
\hline 10-SB10-7-3615 (A) & $10-0796$ & $<100$ & 366 & 2920 & 28100 & $<100$ & $<100$ & 66400 \\
\hline 10-SB10-7-3615 (B) & $10-0796$ & $<100$ & 366 & 2960 & 27000 & $<100$ & $<100$ & 66400 \\
\hline $10-\mathrm{SB} 10-8-3632(\mathrm{~A})$ & $10-0799$ & $<100$ & 247 & 404 & 26000 & 319 & $<100$ & 83300 \\
\hline 10-SB10-8-3632 (B) & 10-0799 & $<100$ & 247 & 404 & 25800 & 319 & $<100$ & 83400 \\
\hline 10-SB10-8-3637 (A) & $10-0800$ & $<100$ & 346 & $<100$ & 33400 & 226 & $<100$ & 86400 \\
\hline 10-SB10-8-3637 (B) & $10-0800$ & $<100$ & 346 & $<100$ & 32000 & 226 & $<100$ & 84900 \\
\hline 10-SB10-9-3815 (A) & $10-0916$ & $<100$ & 219 & $<100$ & 59300 & $<1000$ & 724 & 56000 \\
\hline $10-\mathrm{SB} 10-9-3815(\mathrm{~B})$ & $10-0916$ & $<100$ & 219 & $<100$ & 56000 & $<1000$ & 724 & 56100 \\
\hline 10-SB10-9-3819 (A) & $10-0917$ & $<100$ & 212 & $<100$ & 56800 & $<1000$ & 703 & 49900 \\
\hline 10-SB10-9-3819 (B) & $10-0917$ & $<100$ & 212 & $<100$ & 57000 & $<1000$ & 703 & 49400 \\
\hline
\end{tabular}




\begin{tabular}{|c|c|c|c|}
\hline Sample & Lab ID & Density & pH \\
\hline 10-SB10-1-3566 (A) & $10-0793$ & 1.0635 & 4.83 \\
\hline 10-SB10-1-3566 (B) & $10-0793$ & 1.0633 & \\
\hline 10-SB10-1-3570 (A) & $10-0794$ & 1.1044 & 5.46 \\
\hline 10-SB10-1-3570 (B) & $10-0794$ & 1.1043 & \\
\hline 10-SB10-2-3588 (A) & $10-0797$ & 1.0784 & 2.84 \\
\hline 10-SB10-2-3588 (B) & $10-0797$ & 1.0784 & \\
\hline 10-SB10-2-3592 (A) & $10-0798$ & 1.1202 & 3.46 \\
\hline 10-SB10-2-3592 (B) & $10-0798$ & 1.1202 & \\
\hline 10-SB10-3-3837 (A) & $10-0912$ & 1.0677 & \multirow[t]{2}{*}{4.31} \\
\hline 10-SB10-3-3837 (B) & $10-0912$ & 1.0677 & \\
\hline 10-SB10-3-3841 (A) & $10-0913$ & 1.1027 & \multirow[t]{2}{*}{5.88} \\
\hline 10-SB10-3-3841 (B) & $10-0913$ & 1.1027 & \\
\hline 10-SB10-5-3859 (A) & $10-0914$ & 1.0673 & \multirow[t]{2}{*}{4.74} \\
\hline 10-SB10-5-3859 (B) & $10-0914$ & 1.0673 & \\
\hline $10-\mathrm{SB} 10-5-3863$ (A) & $10-0915$ & 1.0929 & \multirow[t]{2}{*}{6.22} \\
\hline 10-SB10-5-3863 (B) & $10-0915$ & 1.0929 & \\
\hline 10-SB10-7-3611 (A) & $10-0795$ & 1.0690 & 5.22 \\
\hline 10-SB10-7-3611 (B) & $10-0795$ & 1.0689 & \\
\hline 10-SB10-7-3615 (A) & $10-0796$ & 1.0896 & 6.49 \\
\hline 10-SB10-7-3615 (B) & $10-0796$ & 1.0896 & \\
\hline $10-\mathrm{SB} 10-8-3632(\mathrm{~A})$ & $10-0799$ & 1.0831 & 4.01 \\
\hline 10-SB10-8-3632 (B) & $10-0799$ & 1.0831 & \\
\hline 10-SB10-8-3637 (A) & $10-0800$ & 1.0998 & 4.63 \\
\hline 10-SB10-8-3637 (B) & $10-0800$ & 1.0998 & \\
\hline 10-SB10-9-3815 (A) & $10-0916$ & 1.0752 & \multirow[t]{2}{*}{3.47} \\
\hline 10-SB10-9-3815 (B) & $10-0916$ & 1.0753 & \\
\hline $10-\mathrm{SB} 10-9-3819$ (A) & $10-0917$ & 1.0766 & \multirow[t]{2}{*}{3.59} \\
\hline 10-SB10-9-3819 (B) & $10-0917$ & 1.0766 & \\
\hline
\end{tabular}


Table B-2. Analytical Results for Composite Dewater Samples

\begin{tabular}{l} 
Process Science Analytical Laboratory \\
\hline Date: 6/10/10, 7/13/10 \\
\hline
\end{tabular}


Table B-3. Analytical Results for REDOX Samples

\begin{tabular}{|c|c|c|c|c|c|c|}
\hline \multicolumn{7}{|c|}{ SRNL Process Science Analytical Laboratory } \\
\hline \multicolumn{7}{|c|}{ Lab ID: 10-1013 through 10-1029 } \\
\hline Units: absorbance & & & & & $\mathrm{Fe}(2+)$ & $\mathrm{Fe}(2+)$ \\
\hline Sample & Lab ID & $\operatorname{Fe}(2+)$ & $\mathrm{Fe}(3+)$ & Fe(total) & $\mathbf{F e}(3+)$ & Fe(total) \\
\hline EA & & 0.026 & 0.093 & 0.119 & 0.280 & 0.218 \\
\hline 10-SB10-3890 (A) & $10-1013$ & 0.050 & 0.207 & 0.257 & 0.242 & 0.195 \\
\hline 10-SB10-3890 (B) & $10-1013$ & 0.051 & 0.207 & 0.258 & 0.246 & 0.198 \\
\hline 10-SB10-3891 (A) & $10-1014$ & 0.096 & 0.192 & 0.288 & 0.500 & 0.333 \\
\hline 10-SB10-3891 (B) & $10-1014$ & 0.096 & 0.192 & 0.288 & 0.500 & 0.333 \\
\hline 10-SB10-3892 (A) & $10-1015$ & 0.112 & 0.193 & 0.305 & 0.580 & 0.367 \\
\hline 10-SB10-3892 (B) & $10-1015$ & 0.113 & 0.190 & 0.303 & 0.595 & 0.373 \\
\hline 10-SB10-3893 (A) & $10-1016$ & 0.053 & 0.286 & 0.339 & 0.185 & 0.156 \\
\hline 10-SB10-3893 (B) & $10-1016$ & 0.054 & 0.286 & 0.340 & 0.189 & 0.159 \\
\hline 10-SB10-3894 (A) & $10-1017$ & 0.053 & 0.213 & 0.266 & 0.249 & 0.199 \\
\hline 10-SB10-3894 (B) & $10-1017$ & 0.053 & 0.212 & 0.265 & 0.250 & 0.200 \\
\hline 10-SB10-3895 (A) & $10-1018$ & 0.079 & 0.220 & 0.299 & 0.359 & 0.264 \\
\hline 10-SB10-3895 (B) & $10-1018$ & 0.080 & 0.219 & 0.299 & 0.365 & 0.268 \\
\hline 10-SB10-3896 (A) & $10-1019$ & 0.033 & 0.239 & 0.272 & 0.138 & 0.121 \\
\hline 10-SB10-3896 (B) & $10-1019$ & 0.034 & 0.236 & 0.270 & 0.144 & 0.126 \\
\hline 10-SB10-3897 (A) & $10-1020$ & 0.080 & 0.167 & 0.247 & 0.479 & 0.324 \\
\hline 10-SB10-3897 (B) & $10-1020$ & 0.081 & 0.166 & 0.247 & 0.488 & 0.328 \\
\hline 10-SB10-3898 (A) & $10-1021$ & $<0.010$ & 0.230 & 0.230 & All Fe3+ & All Fe3+ \\
\hline 10-SB10-3898 (B) & $10-1021$ & $<0.010$ & 0.231 & 0.231 & All Fe3+ & All Fe3+ \\
\hline 10-SB10-3899 (A) & $10-1022$ & 0.083 & 0.182 & 0.265 & 0.456 & 0.313 \\
\hline 10-SB10-3899 (B) & $10-1022$ & 0.080 & 0.185 & 0.265 & 0.432 & 0.302 \\
\hline 10-SB10-3900 (A) & $10-1023$ & 0.012 & 0.231 & 0.243 & 0.052 & 0.049 \\
\hline 10-SB10-3900 (B) & $10-1023$ & 0.011 & 0.233 & 0.244 & 0.047 & 0.045 \\
\hline 10-SB10-3901 (A) & $10-1024$ & 0.102 & 0.191 & 0.293 & 0.534 & 0.348 \\
\hline
\end{tabular}




\begin{tabular}{|c|c|c|c|c|c|c|}
\hline \multicolumn{7}{|c|}{ SRNL Process Science Analytical Laboratory } \\
\hline \multicolumn{7}{|c|}{ Date: $7 / 15 / 10$} \\
\hline \multicolumn{7}{|c|}{ Lab ID: 10-1013 through 10-1029 } \\
\hline Units: absorbance & & & & & $\mathrm{Fe}(2+)$ & $\mathbf{F e}(2+)$ \\
\hline Sample & Lab ID & $\underline{\mathrm{Fe}(2+)}$ & $\underline{\mathrm{Fe}(3+)}$ & Fe(total) & $\mathrm{Fe}(3+)$ & Fe(total) \\
\hline$\overline{10-S B 10-3901(B)}$ & $\overline{10-1024}$ & $\widetilde{0.103}$ & 0.190 & 0.293 & 0.542 & 0.352 \\
\hline 10-SB10-3902(A) & $10-1025$ & 0.077 & 0.194 & 0.271 & 0.397 & 0.284 \\
\hline 10-SB10-3902 (B) & $10-1025$ & 0.078 & 0.193 & 0.271 & 0.404 & 0.288 \\
\hline 10-SB10-3903 (A) & $10-1026$ & 0.058 & 0.224 & 0.282 & 0.259 & 0.206 \\
\hline 10-SB10-3903 (B) & $10-1026$ & 0.057 & 0.224 & 0.281 & 0.254 & 0.203 \\
\hline $10-\mathrm{SB} 10-3904(\mathrm{~A})$ & $10-1027$ & 0.074 & 0.264 & 0.338 & 0.280 & 0.219 \\
\hline 10-SB10-3904 (B) & $10-1027$ & 0.074 & 0.262 & 0.336 & 0.282 & 0.220 \\
\hline 10-SB10-3905 (A) & $10-1028$ & 0.058 & 0.210 & 0.268 & 0.276 & 0.216 \\
\hline 10-SB10-3905 (B) & $10-1028$ & 0.059 & 0.210 & 0.269 & 0.281 & 0.219 \\
\hline 10-SB10-3908 (A) & $10-1029$ & 0.087 & 0.174 & 0.261 & 0.500 & 0.333 \\
\hline 10-SB10-3908 (B) & $10-1029$ & 0.087 & 0.176 & 0.263 & 0.494 & 0.331 \\
\hline
\end{tabular}


Table B-4. Analytical Results for NaOH Quenched Samples

\begin{tabular}{|c|c|c|c|c|c|c|c|c|}
\hline \multicolumn{9}{|c|}{ Process Science Analytical Laboratory } \\
\hline \multicolumn{9}{|c|}{ Date: $6 / 11 / 10$} \\
\hline \multicolumn{9}{|c|}{ Lab ID: 10-0777-0788, 10-0930-0941 } \\
\hline \multicolumn{9}{|c|}{ Units: mg/L } \\
\hline Sample ID & Lab ID & $\mathbf{F}$ & $\mathbf{C l}$ & NO2 & NO3 & SO4 & $\mathrm{C} 204$ & HCO2 \\
\hline $10-$ SB10-1-3567 (A) & $10-0777$ & $<100$ & $<100$ & 1750 & 41400 & $<100$ & $<100$ & 10200 \\
\hline 10-SB10-1-3567 (B) & $10-0777$ & $<100$ & $<100$ & 1780 & 40900 & $<100$ & $<100$ & 9950 \\
\hline 10-SB10-1-3572(A) & $10-0778$ & $<100$ & $<100$ & $<100$ & 68900 & $<100$ & $<100$ & 13100 \\
\hline 10-SB10-1-3572 (B) & $10-0778$ & $<100$ & $<100$ & $<100$ & 66900 & $<100$ & $<100$ & 13100 \\
\hline $10-\mathrm{SB} 10-1-3575(\mathrm{~A})$ & $10-0779$ & $<100$ & $<100$ & $<100$ & 67600 & $<100$ & $<100$ & 11900 \\
\hline 10-SB10-1-3575 (B) & $10-0779$ & $<100$ & $<100$ & $<100$ & 68600 & $<100$ & $<100$ & 11700 \\
\hline 10-SB10-2-3589 (A) & $10-0783$ & $<100$ & $<100$ & $<100$ & 47800 & $<100$ & $<100$ & 27400 \\
\hline 10-SB10-2-3589 (B) & $10-0783$ & $<100$ & $<100$ & $<100$ & 49100 & $<100$ & $<100$ & 26900 \\
\hline 10-SB10-2-3594 (A) & $10-0784$ & $<100$ & $<100$ & $<100$ & 66900 & $<100$ & $<100$ & 27300 \\
\hline 10-SB10-2-3594 (B) & $10-0784$ & $<100$ & $<100$ & $<100$ & 68000 & $<100$ & $<100$ & 28100 \\
\hline 10-SB10-2-3597 (A) & $10-0785$ & $<100$ & $<100$ & $<100$ & 64400 & $<100$ & $<100$ & 24500 \\
\hline 10-SB10-2-3597 (B) & $10-0785$ & $<100$ & $<100$ & $<100$ & 66500 & $<100$ & $<100$ & 25100 \\
\hline 10-SB10-3-3838 (A) & $10-0930$ & $<100$ & 184 & 2190 & 43000 & $<100$ & $<100$ & 14900 \\
\hline 10-SB10-3-3838 (B) & $10-0930$ & $<100$ & 185 & 2190 & 41400 & $<100$ & $<100$ & 14700 \\
\hline 10-SB10-3-3843 (A) & $10-0931$ & $<100$ & 345 & $<100$ & 67100 & $<100$ & $<100$ & 19700 \\
\hline 10-SB10-3-3843 (B) & $10-0931$ & $<100$ & 346 & $<100$ & 67300 & $<100$ & $<100$ & 19600 \\
\hline 10-SB10-3-3844 (A) & $10-0932$ & $<100$ & 360 & $<100$ & 64300 & $<100$ & $<100$ & 18400 \\
\hline 10-SB10-3-3844 (B) & $10-0932$ & $<100$ & 361 & $<100$ & 63900 & $<100$ & $<100$ & 18300 \\
\hline $10-S B 10-3-3852(\mathrm{~A})$ & $10-0933$ & $<100$ & 368 & $<100$ & 63000 & $<100$ & $<100$ & 20100 \\
\hline 10-SB10-3-3852 (B) & $10-0933$ & $<100$ & 367 & $<100$ & 63700 & $<100$ & $<100$ & 20400 \\
\hline 10-SB10-5-3860 (A) & $10-0934$ & $<100$ & 185 & 4600 & 28100 & $<100$ & $<100$ & 26800 \\
\hline 10-SB10-5-3860 (B) & $10-0934$ & $<100$ & 185 & 4560 & 28100 & $<100$ & $<100$ & 27100 \\
\hline $10-\mathrm{SB} 10-5-3865(\mathrm{~A})$ & $10-0935$ & $<100$ & 286 & 635 & 41400 & $<100$ & $<100$ & 39500 \\
\hline 10-SB10-5-3865 (B) & $10-0935$ & $<100$ & 285 & 635 & 41600 & $<100$ & $<100$ & 40600 \\
\hline
\end{tabular}




\begin{tabular}{|c|c|c|c|c|c|c|c|c|}
\hline \multicolumn{9}{|c|}{ Process Science Analytical Laboratory } \\
\hline \multicolumn{9}{|c|}{ Date: $6 / 11 / 10$} \\
\hline \multicolumn{9}{|c|}{ Lab ID: 10-0777-0788, 10-0930-0941 } \\
\hline \multicolumn{9}{|c|}{ Units: $\mathrm{mg} / \mathrm{L}$} \\
\hline Sample ID & Lab ID & $\underline{\mathbf{F}}$ & $\underline{\mathrm{Cl}}$ & $\underline{\mathrm{NO} 2}$ & $\underline{\mathrm{NO3}}$ & $\underline{\mathrm{SO4}}$ & $\underline{\mathrm{C} 2 \mathrm{O} 4}$ & $\underline{\mathrm{HCO} 2}$ \\
\hline 10-SB10-5-3866 (A) & $\overline{10-0936}$ & $<100$ & $\overline{290}$ & $\overline{<100}$ & $\overline{41300}$ & $\overline{<100}$ & $\overline{<100}$ & $\overline{37100}$ \\
\hline 10-SB10-5-3866 (B) & $10-0936$ & $<100$ & 292 & $<100$ & 41600 & $<100$ & $<100$ & 37100 \\
\hline 10-SB10-5-3874 (A) & $10-0937$ & $<100$ & 283 & $<100$ & 39700 & $<100$ & $<100$ & 36900 \\
\hline 10-SB10-5-3874 (B) & $10-0937$ & $<100$ & 283 & $<100$ & 40300 & $<100$ & $<100$ & 39200 \\
\hline $10-\mathrm{SB} 10-7-3612(\mathrm{~A})$ & $10-0780$ & $<100$ & $<100$ & 5800 & 13400 & $<100$ & $<100$ & 41600 \\
\hline 10-SB10-7-3612 (B) & $10-0780$ & $<100$ & $<100$ & 5930 & 13600 & $<100$ & $<100$ & 41100 \\
\hline 10-SB10-7-3617 (A) & $10-0781$ & $<100$ & $<100$ & 2300 & 18700 & $<100$ & $<100$ & 55500 \\
\hline 10-SB10-7-3617 (B) & $10-0781$ & $<100$ & $<100$ & 2220 & 18800 & $<100$ & $<100$ & 56300 \\
\hline 10-SB10-7-3620 (A) & $10-0782$ & $<100$ & $<100$ & 1250 & 18000 & $<100$ & $<100$ & 52700 \\
\hline 10-SB10-7-3620 (B) & $10-0782$ & $<100$ & $<100$ & 1380 & 18300 & $<100$ & $<100$ & 53800 \\
\hline $10-\mathrm{SB} 10-8-3633$ (A) & $10-0786$ & $<100$ & $<100$ & 830 & 17200 & $<100$ & $<100$ & 61300 \\
\hline 10-SB10-8-3633 (B) & $10-0786$ & $<100$ & $<100$ & 843 & 16900 & $<100$ & $<100$ & 61500 \\
\hline 10-SB10-8-3639 (A) & $10-0787$ & $<100$ & $<100$ & $<100$ & 19900 & $<100$ & $<100$ & 67500 \\
\hline 10-SB10-8-3639 (B) & $10-0787$ & $<100$ & $<100$ & $<100$ & 20000 & $<100$ & $<100$ & 68000 \\
\hline 10-SB10-8-3642 (A) & $10-0788$ & $<100$ & $<100$ & $<100$ & 17200 & $<100$ & $<100$ & 58800 \\
\hline 10-SB10-8-3642 (B) & $10-0788$ & $<100$ & $<100$ & $<100$ & 17100 & $<100$ & $<100$ & 59800 \\
\hline 10-SB10-9-3816 (A) & $10-0938$ & $<100$ & 182 & $<100$ & 42700 & $<100$ & $<100$ & 33500 \\
\hline 10-SB10-9-3816 (B) & $10-0938$ & $<100$ & 182 & $<100$ & 42500 & $<100$ & $<100$ & 33100 \\
\hline 10-SB10-9-3821 (A) & $10-0939$ & $<100$ & 198 & $<100$ & 42200 & $<100$ & $<100$ & 29700 \\
\hline 10-SB10-9-3821 (B) & $10-0939$ & $<100$ & 198 & $<100$ & 42400 & $<100$ & $<100$ & 30200 \\
\hline 10-SB10-9-3822 (A) & $10-0940$ & $<100$ & 295 & $<100$ & 56600 & $<100$ & $<100$ & 34700 \\
\hline 10-SB10-9-3822 (B) & $10-0940$ & $<100$ & 294 & $<100$ & 57000 & $<100$ & $<100$ & 37700 \\
\hline $10-S B 10-9-3830$ (A) & $10-0941$ & $<100$ & 313 & $<100$ & 57900 & $<100$ & $<100$ & 37400 \\
\hline 10-SB10-9-3830 (B) & $10-0941$ & $<100$ & 310 & $<100$ & 58600 & $<100$ & $<100$ & 37800 \\
\hline
\end{tabular}


SRNL-STI-2010-00589

Revision 0

Appendix C: Offgas Composition Results from Experiments 


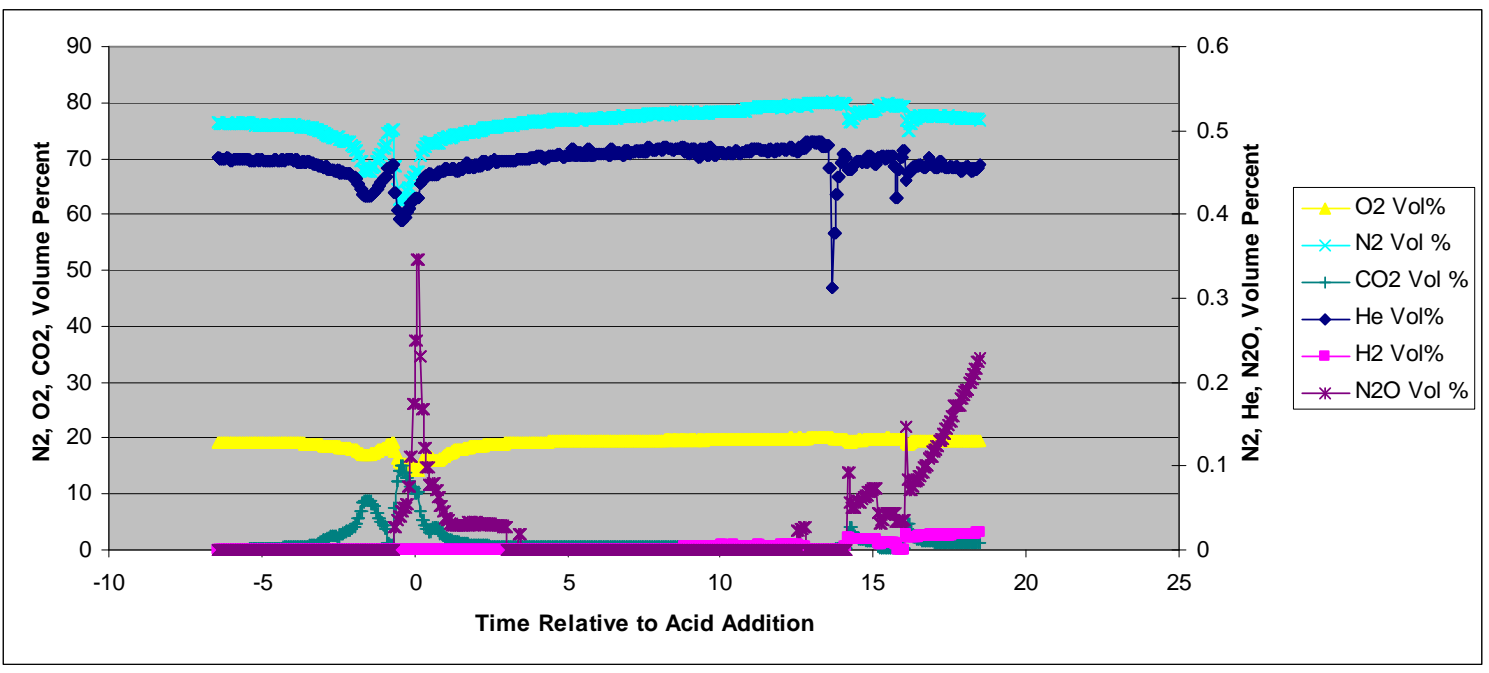

Figure C-1. SB10-1 Offgas Graph

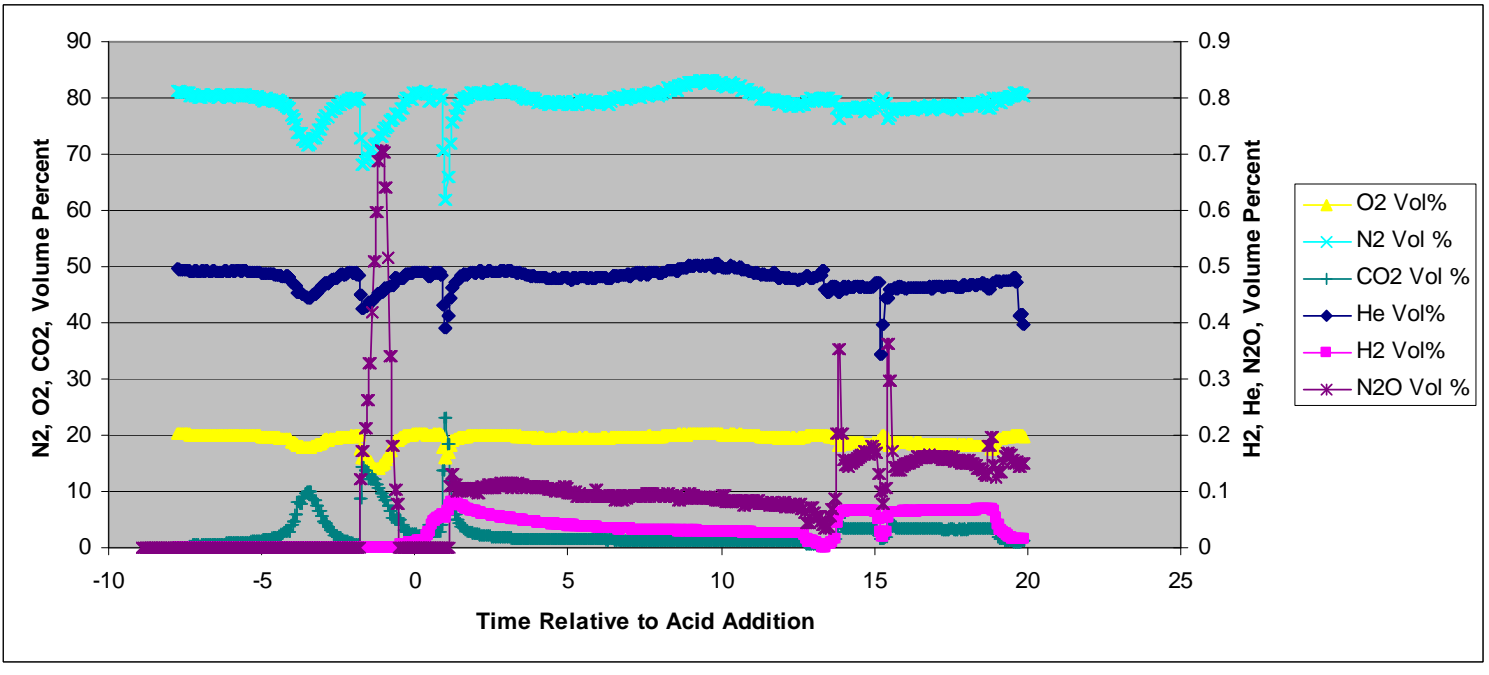

Figure C-2. SB10-2 Offgas Graph 


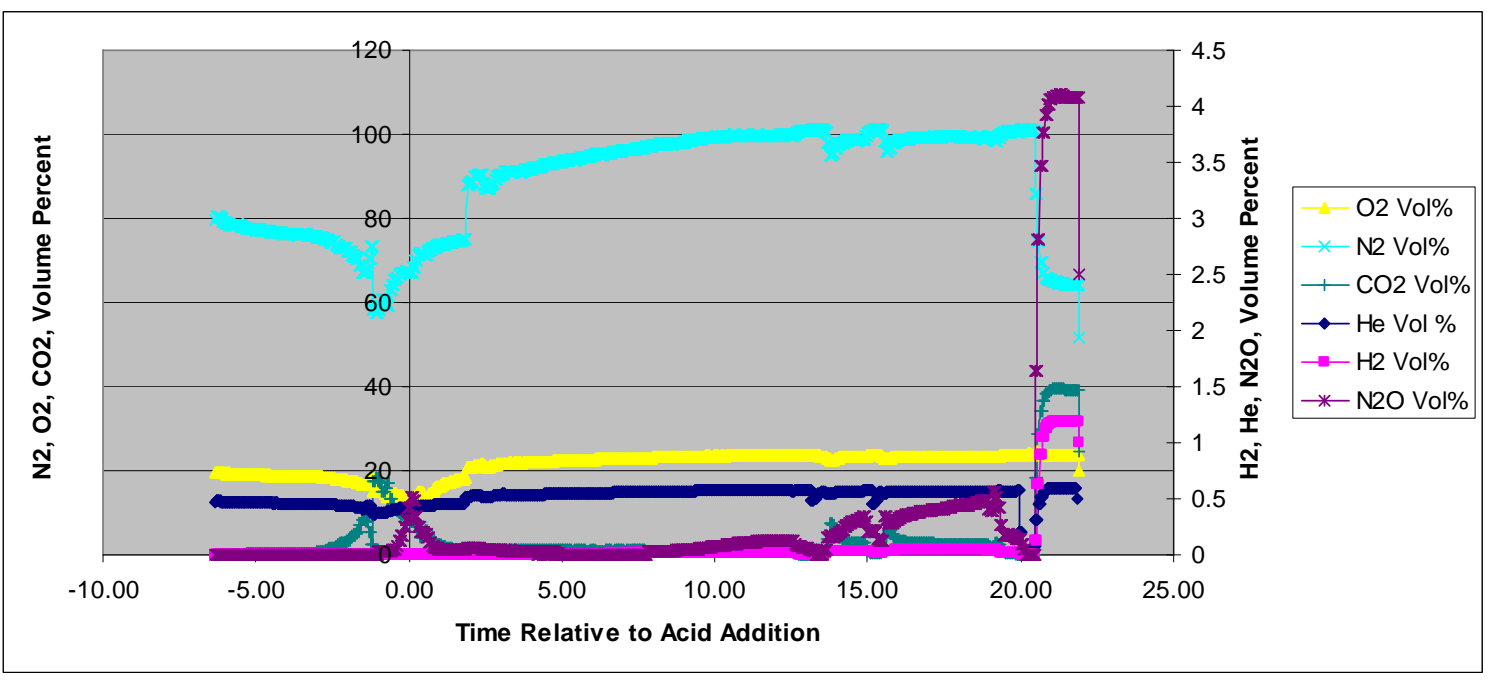

Figure C-3. SB10-3 Offgas Graph

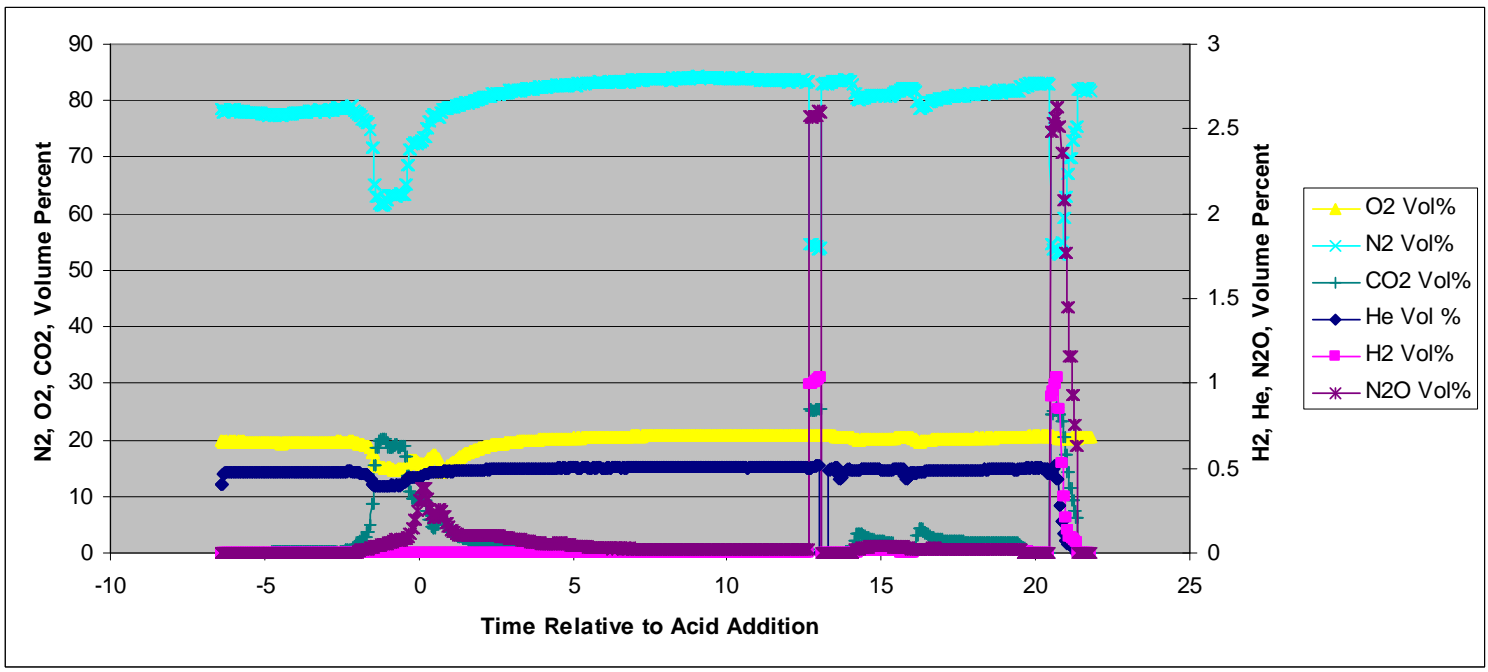

Figure C-4. SB10-5 Offgas Graph 


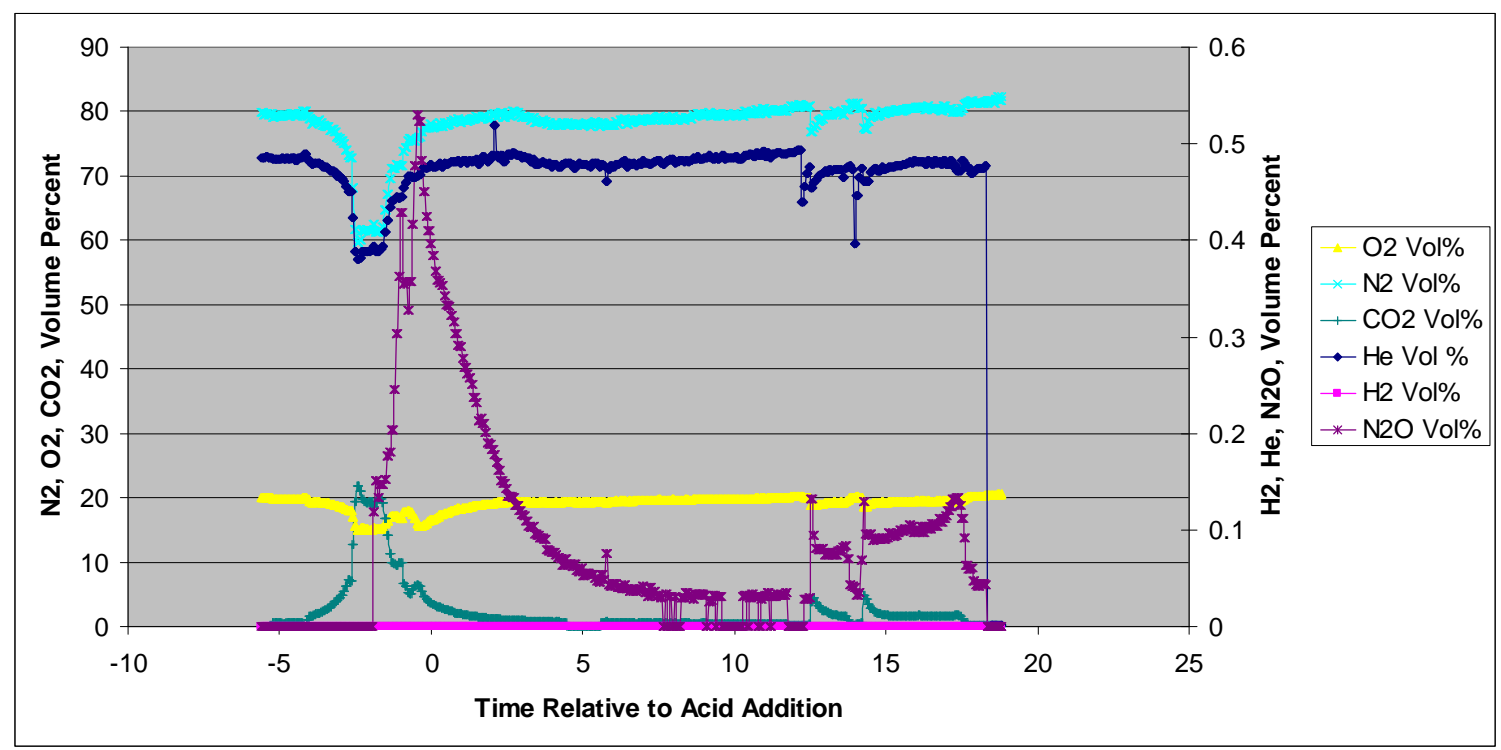

Figure C-5. SB10-7 Offgas Graph

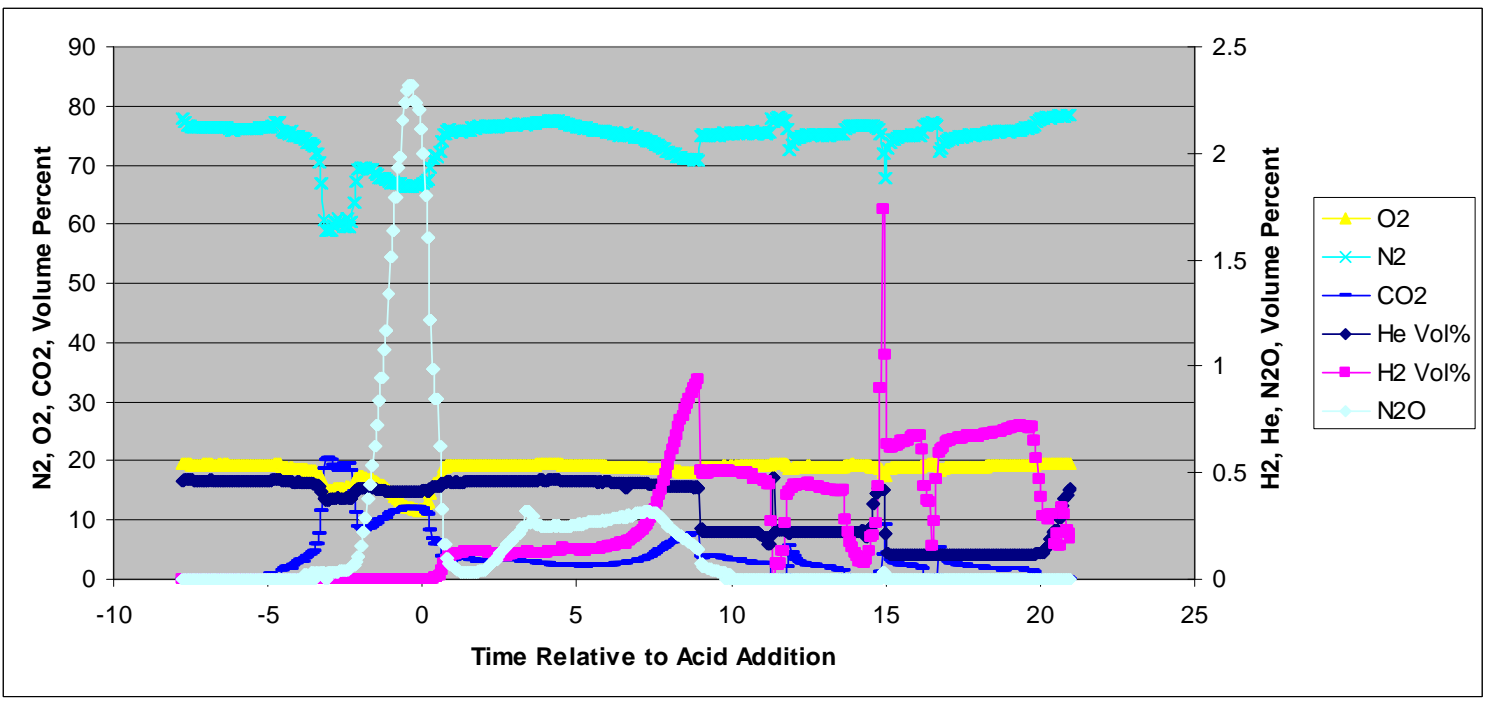

Figure C-6. SB10-8 Offgas Graph 
SRNL-STI-2010-00589

Revision 0

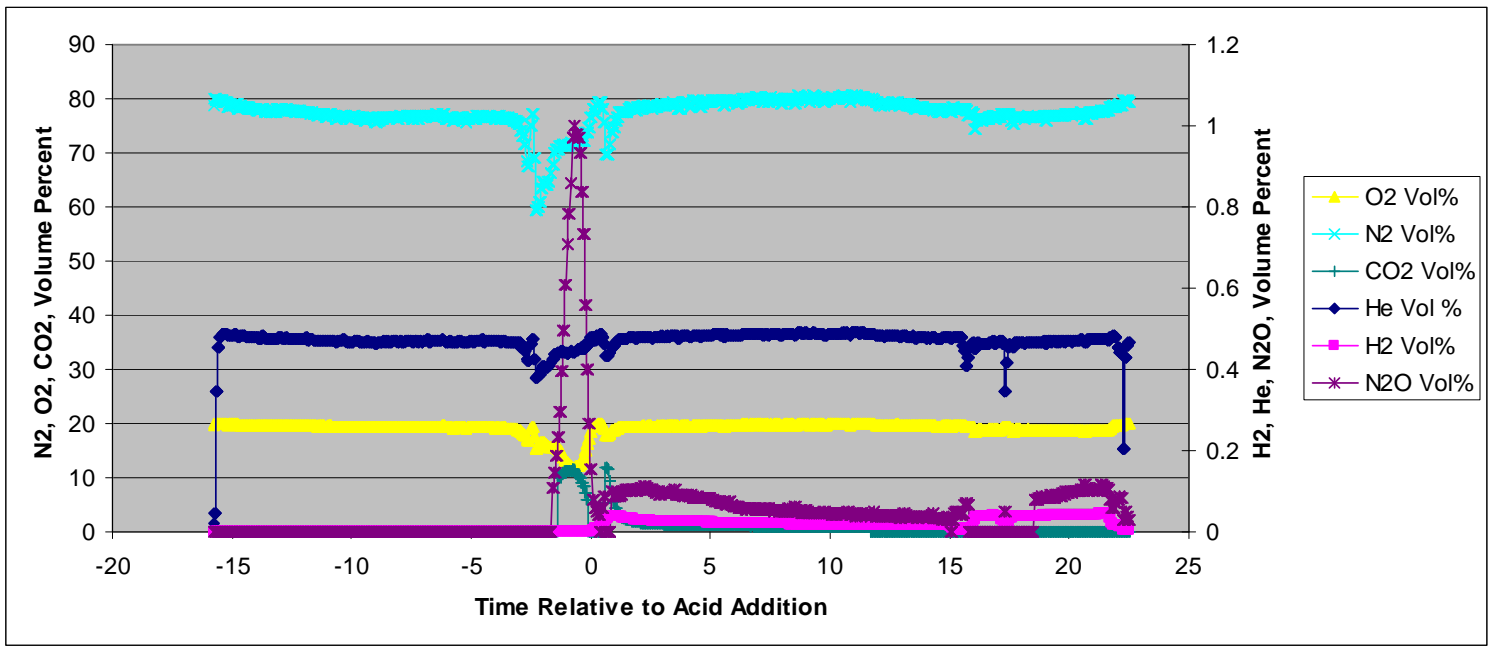

Figure C-7. SB10-9 Offgas Graph 
SRNL-STI-2010-00589

Revision 0

Appendix D: Predicted Compositions of SB10 Baseline Melter Feeds 
Table D-1. Composition of SB10-1 Baseline Melter Feed at 1.5 GPM

\begin{tabular}{|c|c|c|c|}
\hline Insoluble Solids & $\mathrm{lb} / \mathrm{hr}$ & Soluble Solids & $\mathrm{lb} / \mathrm{hr}$ \\
\hline $\mathrm{Fe}(\mathrm{OH}) 3$ & 113.4707 & $\mathrm{Ca}(\mathrm{COOH}) 2$ & \\
\hline $\mathrm{Al}(\mathrm{OH}) 3$ & 28.2329 & $\mathrm{Ca}(\mathrm{NO} 3) 2$ & 19.0638 \\
\hline $\mathrm{MnO} 2$ & 11.6667 & $\mathrm{Cu}(\mathrm{COOH}) 2$ & \\
\hline $\mathrm{Ca}(\mathrm{OH}) 2$ & 1.5115 & $\mathrm{Cu}(\mathrm{NO} 3) 2$ & \\
\hline $\mathrm{Mg}(\mathrm{OH}) 2$ & 0.6035 & $\mathrm{KCOOH}$ & \\
\hline $\mathrm{HgO}$ & 0.0137 & KNO3 & 1.2778 \\
\hline $\mathrm{Ni}(\mathrm{OH}) 2$ & 2.4969 & $\mathrm{Mg}(\mathrm{COOH}) 2$ & 0.0000 \\
\hline $\mathrm{Cr}(\mathrm{OH}) 3$ & 0.6266 & $\mathrm{Mg}(\mathrm{NO} 3) 2$ & 2.9267 \\
\hline $\mathrm{Cu}(\mathrm{OH}) 2$ & 0.1821 & $\mathrm{Mn}(\mathrm{COOH}) 2$ & 9.4924 \\
\hline TiO2 & 0.4514 & $\mathrm{Mn}(\mathrm{NO} 3) 2$ & \\
\hline $\mathrm{SiO} 2$ & 223.7553 & $\mathrm{NaCl}$ & \\
\hline $\mathrm{Na} 2 \mathrm{O}$ & 22.1956 & $\mathrm{NaF}$ & \\
\hline $\mathrm{Zn}(\mathrm{OH}) 2$ & 0.2404 & $\mathrm{NaCOOH}$ & 9.1568 \\
\hline $\mathrm{K} 2 \mathrm{O}$ & & NaNO3 & 70.4007 \\
\hline $\mathrm{RuO} 2$ & & NaNO2 & \\
\hline $\mathrm{RhO} 2$ & 0.0518 & $\mathrm{Na3PO} 4$ & \\
\hline $\mathrm{PdO}$ & & $\mathrm{Ni}(\mathrm{COOH}) 2$ & \\
\hline $\mathrm{B} 2 \mathrm{O} 3$ & 22.1956 & $\mathrm{Ni}(\mathrm{NO} 3) 2$ & \\
\hline $\mathrm{Li} 2 \mathrm{O}$ & 22.1956 & $\mathrm{La}(\mathrm{COOH}) 3$ & \\
\hline BaSO4 & 0.8063 & $\mathrm{La}(\mathrm{NO} 3) 3$ & \\
\hline $\mathrm{PbSO} 4$ & & $\mathrm{Zn}(\mathrm{COOH}) 2$ & \\
\hline $\mathrm{La}(\mathrm{OH}) 3$ & & $\mathrm{Zn}(\mathrm{NO} 3) 2$ & \\
\hline $\mathrm{ZrO} 2$ & 1.1749 & $\mathrm{Na} 2 \mathrm{CO} 3$ & \\
\hline $\mathrm{CaCO} 3$ & & $\mathrm{Na} 2 \mathrm{C} 2 \mathrm{O} 4$ & \\
\hline CaSO4 & 0.1381 & $\mathrm{Na} 2 \mathrm{SO} 4$ & 0.0659 \\
\hline $\mathrm{MgO}$ & 0.0000 & $\mathrm{Fe}(\mathrm{NO} 3) 3$ & \\
\hline Coal-carbon & 19.8558 & $\mathrm{Si}(\mathrm{OH}) 4$ & \\
\hline NaTi2O5H & & $\mathrm{HCOOH}$ & \\
\hline \multirow[t]{3}{*}{ Total_1 } & 471.8653 & Total_2 & 112.3841 \\
\hline & & $\mathrm{H} 2 \mathrm{O}$ & 527.3363 \\
\hline & & Total & 1111.5857 \\
\hline
\end{tabular}


Table D-2. Composition of SB10-2 Baseline Melter Feed at 1.5 GPM

\begin{tabular}{|c|c|c|c|}
\hline Insoluble Solids & $\mathrm{lb} / \mathrm{hr}$ & Soluble Solids & $\mathrm{lb} / \mathrm{hr}$ \\
\hline $\mathrm{Fe}(\mathrm{OH}) 3$ & 101.2382 & $\mathrm{Ca}(\mathrm{COOH}) 2$ & \\
\hline $\mathrm{Al}(\mathrm{OH}) 3$ & 26.7981 & $\mathrm{Ca}(\mathrm{NO} 3) 2$ & 18.0661 \\
\hline $\mathrm{MnO} 2$ & 1.7851 & $\mathrm{Cu}(\mathrm{COOH}) 2$ & \\
\hline $\mathrm{Ca}(\mathrm{OH}) 2$ & 1.8592 & $\mathrm{Cu}(\mathrm{NO} 3) 2$ & \\
\hline $\mathrm{Mg}(\mathrm{OH}) 2$ & 0.5217 & $\mathrm{KCOOH}$ & \\
\hline $\mathrm{HgO}$ & 0.0097 & KNO3 & 1.1436 \\
\hline $\mathrm{Ni}(\mathrm{OH}) 2$ & 1.6126 & $\mathrm{Mg}(\mathrm{COOH}) 2$ & \\
\hline $\mathrm{Cr}(\mathrm{OH}) 3$ & 0.6477 & $\mathrm{Mg}(\mathrm{NO} 3) 2$ & 3.2482 \\
\hline $\mathrm{Cu}(\mathrm{OH}) 2$ & 0.1386 & $\mathrm{Mn}(\mathrm{COOH}) 2$ & 24.7226 \\
\hline $\mathrm{TiO} 2$ & 0.4027 & $\mathrm{Mn}(\mathrm{NO} 3) 2$ & \\
\hline $\mathrm{SiO} 2$ & 213.0266 & $\mathrm{NaCl}$ & \\
\hline $\mathrm{Na} 2 \mathrm{O}$ & 21.1309 & $\mathrm{NaF}$ & \\
\hline $\mathrm{Zn}(\mathrm{OH}) 2$ & 0.2140 & $\mathrm{NaCOOH}$ & 10.8766 \\
\hline $\mathrm{K} 2 \mathrm{O}$ & & NaNO3 & 36.3974 \\
\hline $\mathrm{RuO} 2$ & & $\mathrm{NaNO} 2$ & \\
\hline $\mathrm{RhO} 2$ & 0.0504 & $\mathrm{Na3PO} 4$ & \\
\hline $\mathrm{PdO}$ & & $\mathrm{Ni}(\mathrm{COOH}) 2$ & \\
\hline $\mathrm{B} 2 \mathrm{O} 3$ & 21.1309 & $\mathrm{Ni}(\mathrm{NO} 3) 2$ & 1.7887 \\
\hline $\mathrm{Li} 2 \mathrm{O}$ & 21.1309 & $\mathrm{La}(\mathrm{COOH}) 3$ & \\
\hline $\mathrm{BaSO} 4$ & 0.7516 & $\mathrm{La}(\mathrm{NO} 3) 3$ & \\
\hline $\mathrm{PbSO} 4$ & & $\mathrm{Zn}(\mathrm{COOH}) 2$ & \\
\hline $\mathrm{La}(\mathrm{OH}) 3$ & 0 & $\mathrm{Zn}(\mathrm{NO} 3) 2$ & 0.0379 \\
\hline $\mathrm{ZrO} 2$ & 1.1429 & $\mathrm{Na} 2 \mathrm{CO} 3$ & \\
\hline $\mathrm{CaCO} 3$ & & $\mathrm{Na} 2 \mathrm{C} 2 \mathrm{O} 4$ & \\
\hline CaSO4 & 0.1444 & $\mathrm{Na} 2 \mathrm{SO} 4$ & 0.0735 \\
\hline $\mathrm{MgO}$ & & $\mathrm{Fe}(\mathrm{NO} 3) 3$ & 19.0370 \\
\hline Coal-carbon & 15.1481 & $\mathrm{Si}(\mathrm{OH}) 4$ & 0.2245 \\
\hline NaTi2O5H & 0.0981 & $\mathrm{HCOOH}$ & \\
\hline \multirow[t]{3}{*}{ Total_1 } & 428.9824 & Total_2 & 115.6236 \\
\hline & & $\mathrm{H} 2 \mathrm{O}$ & 533.1815 \\
\hline & & Total & 1077.7875 \\
\hline
\end{tabular}


Table D-3. Composition of SB10-3 Baseline Melter Feed at 1.5 GPM.

\begin{tabular}{|c|c|c|c|}
\hline Insoluble Solids & $\mathrm{lb} / \mathrm{hr}$ & Soluble Solids & $\mathrm{lb} / \mathrm{hr}$ \\
\hline $\mathrm{FeOOH}$ & 135.9715 & $\mathrm{Ca}(\mathrm{COOH}) 2$ & \\
\hline $\mathrm{Al}(\mathrm{OH}) 3$ & 37.7853 & $\mathrm{Ca}(\mathrm{NO} 3) 2$ & 20.8762 \\
\hline $\mathrm{MnO} 2$ & 8.2320 & $\mathrm{Cu}(\mathrm{COOH}) 2$ & \\
\hline $\mathrm{Ca}(\mathrm{OH}) 2$ & & $\mathrm{Cu}(\mathrm{NO} 3) 2$ & \\
\hline $\mathrm{Mg}(\mathrm{OH}) 2$ & 0.7428 & $\mathrm{KCOOH}$ & \\
\hline $\mathrm{HgO}$ & 0.0186 & KNO3 & 1.6559 \\
\hline $\mathrm{Ni}(\mathrm{OH}) 2$ & 2.6964 & $\mathrm{Mg}(\mathrm{COOH}) 2$ & \\
\hline $\mathrm{Cr}(\mathrm{OH}) 3$ & 0.6579 & $\mathrm{Mg}(\mathrm{NO} 3) 2$ & 2.7410 \\
\hline $\mathrm{Cu}(\mathrm{OH}) 2$ & & $\mathrm{Mn}(\mathrm{COOH}) 2$ & 9.5532 \\
\hline $\mathrm{TiO} 2$ & 0.3678 & $\mathrm{Mn}(\mathrm{NO} 3) 2$ & \\
\hline $\mathrm{SiO} 2$ & 228.4196 & $\mathrm{NaCl}$ & 0.5853 \\
\hline $\mathrm{Na} 2 \mathrm{O}$ & 24.0115 & $\mathrm{NaF}$ & \\
\hline $\mathrm{Zn}(\mathrm{OH}) 2$ & 0.2524 & $\mathrm{NaCOOH}$ & 18.3139 \\
\hline $\mathrm{K} 2 \mathrm{O}$ & & NaNO3 & 60.2865 \\
\hline $\mathrm{RuO} 2$ & & NaNO2 & \\
\hline $\mathrm{RhO} 2$ & 0.2798 & $\mathrm{Na} 3 \mathrm{PO} 4$ & \\
\hline $\mathrm{PdO}$ & & $\mathrm{Ni}(\mathrm{COOH}) 2$ & \\
\hline $\mathrm{B} 2 \mathrm{O} 3$ & 24.0115 & $\mathrm{Ni}(\mathrm{NO} 3) 2$ & \\
\hline Li2O & 24.0115 & $\mathrm{La}(\mathrm{COOH}) 3$ & \\
\hline $\mathrm{BaSO} 4$ & 0.9271 & $\mathrm{La}(\mathrm{NO} 3) 3$ & \\
\hline $\mathrm{PbSO} 4$ & 0.2430 & $\mathrm{Zn}(\mathrm{COOH}) 2$ & \\
\hline $\mathrm{La}(\mathrm{OH}) 3$ & & $\mathrm{Zn}(\mathrm{NO} 3) 2$ & \\
\hline $\mathrm{ZrO} 2$ & 1.4097 & $\mathrm{Na} 2 \mathrm{CO} 3$ & \\
\hline $\mathrm{CaCO} 3$ & & $\mathrm{Na} 2 \mathrm{C} 2 \mathrm{O} 4$ & \\
\hline CaSO4 & & $\mathrm{Na} 2 \mathrm{SO} 4$ & 0.0813 \\
\hline $\mathrm{MgO}$ & & $\mathrm{Fe}(\mathrm{NO} 3) 3$ & \\
\hline Coal-carbon & 12.6492 & $\mathrm{Si}(\mathrm{OH}) 4$ & 0.0723 \\
\hline NaTi2O5H & & $\mathrm{HCOOH}$ & \\
\hline \multirow[t]{3}{*}{ Total_1 } & 502.6879 & Total_2 & 114.1588 \\
\hline & & $\mathrm{H} 2 \mathrm{O}$ & 517.2712 \\
\hline & & Total & 1134.1179 \\
\hline
\end{tabular}


Table D- 4. Composition of SB10-5 Baseline Melter Feed at 1.5 GPM.

\begin{tabular}{|c|c|c|c|}
\hline Insoluble Solids & $\mathrm{lb} / \mathrm{hr}$ & Soluble Solids & $\mathrm{lb} / \mathrm{hr}$ \\
\hline $\mathrm{Fe}(\mathrm{OH}) 3$ & 127.5660 & $\mathrm{Ca}(\mathrm{COOH}) 2$ & \\
\hline $\mathrm{Al}(\mathrm{OH}) 3$ & 41.3559 & $\mathrm{Ca}(\mathrm{NO} 3) 2$ & 19.3947 \\
\hline $\mathrm{MnO} 2$ & 12.1037 & $\mathrm{Cu}(\mathrm{COOH}) 2$ & \\
\hline $\mathrm{Ca}(\mathrm{OH}) 2$ & & $\mathrm{Cu}(\mathrm{NO} 3) 2$ & \\
\hline $\mathrm{Mg}(\mathrm{OH}) 2$ & 0.6730 & $\mathrm{KCOOH}$ & \\
\hline $\mathrm{HgO}$ & 0.0186 & KNO3 & 1.2368 \\
\hline $\mathrm{Ni}(\mathrm{OH}) 2$ & 2.5534 & $\mathrm{Mg}(\mathrm{COOH}) 2$ & \\
\hline $\mathrm{Cr}(\mathrm{OH}) 3$ & 0.6318 & $\mathrm{Mg}(\mathrm{NO} 3) 2$ & 2.5957 \\
\hline $\mathrm{Cu}(\mathrm{OH}) 2$ & & $\mathrm{Mn}(\mathrm{COOH}) 2$ & 2.5951 \\
\hline $\mathrm{TiO} 2$ & 0.1710 & $\mathrm{Mn}(\mathrm{NO} 3) 2$ & \\
\hline $\mathrm{SiO} 2$ & 222.0141 & $\mathrm{NaCl}$ & 0.5162 \\
\hline $\mathrm{Na} 2 \mathrm{O}$ & 23.3420 & $\mathrm{NaF}$ & \\
\hline $\mathrm{Zn}(\mathrm{OH}) 2$ & 0.2424 & $\mathrm{NaCOOH}$ & 57.8967 \\
\hline $\mathrm{K} 2 \mathrm{O}$ & & NaNO3 & 37.0447 \\
\hline $\mathrm{RuO} 2$ & & $\mathrm{NaNO} 2$ & \\
\hline $\mathrm{RhO} 2$ & 0.2687 & $\mathrm{Na} 3 \mathrm{PO} 4$ & \\
\hline $\mathrm{PdO}$ & & $\mathrm{Ni}(\mathrm{COOH}) 2$ & \\
\hline $\mathrm{B} 2 \mathrm{O} 3$ & 23.3420 & $\mathrm{Ni}(\mathrm{NO} 3) 2$ & \\
\hline $\mathrm{Li} 2 \mathrm{O}$ & 23.3420 & $\mathrm{La}(\mathrm{COOH}) 3$ & \\
\hline $\mathrm{BaSO} 4$ & 0.8516 & $\mathrm{La}(\mathrm{NO} 3) 3$ & \\
\hline $\mathrm{PbSO} 4$ & 0.3000 & $\mathrm{Zn}(\mathrm{COOH}) 2$ & \\
\hline $\mathrm{La}(\mathrm{OH}) 3$ & 0.0000 & $\mathrm{Zn}(\mathrm{NO} 3) 2$ & \\
\hline $\mathrm{ZrO} 2$ & 1.4153 & $\mathrm{Na} 2 \mathrm{CO} 3$ & \\
\hline $\mathrm{CaCO} 3$ & & $\mathrm{Na} 2 \mathrm{C} 2 \mathrm{O} 4$ & \\
\hline $\mathrm{CaSO} 4$ & & $\mathrm{Na} 2 \mathrm{SO} 4$ & 0.1263 \\
\hline $\mathrm{MgO}$ & & $\mathrm{Fe}(\mathrm{NO} 3) 3$ & \\
\hline Coal-carbon & 6.7266 & $\mathrm{Si}(\mathrm{OH}) 4$ & 0.0437 \\
\hline NaTi2O5H & & $\mathrm{HCOOH}$ & \\
\hline \multirow[t]{3}{*}{ Total_1 } & 486.9181 & Total_2 & 121.3776 \\
\hline & & $\mathrm{H} 2 \mathrm{O}$ & 521.3157 \\
\hline & & Total & 1129.6114 \\
\hline
\end{tabular}


Table D- 5. Composition of SB10-7 Baseline Melter Feed at 1.5 GPM.

\begin{tabular}{|c|c|c|c|}
\hline Insoluble Solids & $\mathrm{lb} / \mathrm{hr}$ & Soluble Solids & $\mathrm{lb} / \mathrm{hr}$ \\
\hline $\mathrm{Fe}(\mathrm{OH}) 3$ & 111.5852 & $\mathrm{Ca}(\mathrm{COOH}) 2$ & \\
\hline $\mathrm{Al}(\mathrm{OH}) 3$ & 41.0774 & $\mathrm{Ca}(\mathrm{NO} 3) 2$ & 16.0985 \\
\hline $\mathrm{MnO} 2$ & 16.6026 & $\mathrm{Cu}(\mathrm{COOH}) 2$ & \\
\hline $\mathrm{Ca}(\mathrm{OH}) 2$ & 2.6461 & $\mathrm{Cu}(\mathrm{NO} 3) 2$ & \\
\hline $\mathrm{Mg}(\mathrm{OH}) 2$ & 0.6256 & $\mathrm{KCOOH}$ & \\
\hline $\mathrm{HgO}$ & 0.0301 & KNO3 & 0.8421 \\
\hline $\mathrm{Ni}(\mathrm{OH}) 2$ & 2.4425 & $\mathrm{Mg}(\mathrm{COOH}) 2$ & \\
\hline $\mathrm{Cr}(\mathrm{OH}) 3$ & 0.6453 & $\mathrm{Mg}(\mathrm{NO} 3) 2$ & 2.7549 \\
\hline $\mathrm{Cu}(\mathrm{OH}) 2$ & 0.1875 & $\mathrm{Mn}(\mathrm{COOH}) 2$ & 1.5869 \\
\hline $\mathrm{TiO} 2$ & & $\mathrm{Mn}(\mathrm{NO} 3) 2$ & \\
\hline $\mathrm{SiO} 2$ & 229.7239 & $\mathrm{NaCl}$ & \\
\hline $\mathrm{Na} 2 \mathrm{O}$ & 23.2556 & $\mathrm{NaF}$ & \\
\hline $\mathrm{Zn}(\mathrm{OH}) 2$ & 0.2166 & $\mathrm{NaCOOH}$ & 89.8018 \\
\hline $\mathrm{K} 2 \mathrm{O}$ & & NaNO3 & 7.6854 \\
\hline $\mathrm{RuO} 2$ & & $\mathrm{NaNO} 2$ & 2.2379 \\
\hline $\mathrm{RhO} 2$ & 0.0534 & $\mathrm{Na} 3 \mathrm{PO} 4$ & \\
\hline $\mathrm{PdO}$ & & $\mathrm{Ni}(\mathrm{COOH}) 2$ & \\
\hline $\mathrm{B} 2 \mathrm{O} 3$ & 23.2556 & $\mathrm{Ni}(\mathrm{NO} 3) 2$ & \\
\hline $\mathrm{Li} 2 \mathrm{O}$ & 23.2556 & $\mathrm{La}(\mathrm{COOH}) 3$ & \\
\hline BaSO4 & 0.7264 & $\mathrm{La}(\mathrm{NO} 3) 3$ & \\
\hline $\mathrm{PbSO} 4$ & & $\mathrm{Zn}(\mathrm{COOH}) 2$ & \\
\hline $\mathrm{La}(\mathrm{OH}) 3$ & & $\mathrm{Zn}(\mathrm{NO} 3) 2$ & \\
\hline $\mathrm{ZrO} 2$ & 1.2923 & $\mathrm{Na} 2 \mathrm{CO} 3$ & \\
\hline $\mathrm{CaCO} 3$ & & $\mathrm{Na} 2 \mathrm{C} 2 \mathrm{O} 4$ & \\
\hline CaSO4 & 0.0336 & $\mathrm{Na} 2 \mathrm{SO} 4$ & 0.1541 \\
\hline $\mathrm{MgO}$ & & $\mathrm{Fe}(\mathrm{NO} 3) 3$ & \\
\hline Coal-carbon & & $\mathrm{Si}(\mathrm{OH}) 4$ & \\
\hline NaTi2O5H & & $\mathrm{HCOOH}$ & \\
\hline \multirow[t]{3}{*}{ Total_1 } & 477.6553 & Total_2 & 121.1616 \\
\hline & & $\mathrm{H} 2 \mathrm{O}$ & 524.0349 \\
\hline & & Total & 1122.8518 \\
\hline
\end{tabular}


Table D- 6. Composition of SB10-8 Baseline Melter Feed at 1.5 GPM.

\begin{tabular}{|c|c|c|c|}
\hline Insoluble Solids & $\mathrm{lb} / \mathrm{hr}$ & Soluble Solids & $\mathrm{lb} / \mathrm{hr}$ \\
\hline $\mathrm{Fe}(\mathrm{OH}) 3$ & 112.3814 & $\mathrm{Ca}(\mathrm{COOH}) 2$ & \\
\hline $\mathrm{Al}(\mathrm{OH}) 3$ & 41.6885 & $\mathrm{Ca}(\mathrm{NO} 3) 2$ & 16.6232 \\
\hline $\mathrm{MnO} 2$ & 13.8747 & $\mathrm{Cu}(\mathrm{COOH}) 2$ & \\
\hline $\mathrm{Ca}(\mathrm{OH}) 2$ & 2.5273 & $\mathrm{Cu}(\mathrm{NO} 3) 2$ & \\
\hline $\mathrm{Mg}(\mathrm{OH}) 2$ & 0.7532 & $\mathrm{KCOOH}$ & \\
\hline $\mathrm{HgO}$ & 0.0003 & KNO3 & 0.8571 \\
\hline $\mathrm{Ni}(\mathrm{OH}) 2$ & 2.7477 & $\mathrm{Mg}(\mathrm{COOH}) 2$ & \\
\hline $\mathrm{Cr}(\mathrm{OH}) 3$ & 0.6978 & $\mathrm{Mg}(\mathrm{NO} 3) 2$ & 3.1397 \\
\hline $\mathrm{Cu}(\mathrm{OH}) 2$ & & $\mathrm{Mn}(\mathrm{COOH}) 2$ & 6.2181 \\
\hline $\mathrm{TiO} 2$ & & $\mathrm{Mn}(\mathrm{NO} 3) 2$ & \\
\hline $\mathrm{SiO} 2$ & 240.2285 & $\mathrm{NaCl}$ & \\
\hline $\mathrm{Na} 2 \mathrm{O}$ & 24.3356 & $\mathrm{NaF}$ & \\
\hline $\mathrm{Zn}(\mathrm{OH}) 2$ & 0.2519 & $\mathrm{NaCOOH}$ & 93.4471 \\
\hline $\mathrm{K} 2 \mathrm{O}$ & & NaNO3 & 4.5075 \\
\hline $\mathrm{RuO} 2$ & & $\mathrm{NaNO} 2$ & \\
\hline $\mathrm{RhO} 2$ & 0.0543 & $\mathrm{Na} 3 \mathrm{PO} 4$ & \\
\hline $\mathrm{PdO}$ & & $\mathrm{Ni}(\mathrm{COOH}) 2$ & \\
\hline $\mathrm{B} 2 \mathrm{O} 3$ & 24.3356 & $\mathrm{Ni}(\mathrm{NO} 3) 2$ & \\
\hline $\mathrm{Li} 2 \mathrm{O}$ & 24.3356 & $\mathrm{La}(\mathrm{COOH}) 3$ & \\
\hline $\mathrm{BaSO} 4$ & 0.7746 & $\mathrm{La}(\mathrm{NO} 3) 3$ & \\
\hline $\mathrm{PbSO} 4$ & & $\mathrm{Zn}(\mathrm{COOH}) 2$ & \\
\hline $\mathrm{La}(\mathrm{OH}) 3$ & & $\mathrm{Zn}(\mathrm{NO} 3) 2$ & \\
\hline $\mathrm{ZrO} 2$ & 1.4272 & $\mathrm{Na} 2 \mathrm{CO} 3$ & \\
\hline $\mathrm{CaCO} 3$ & & $\mathrm{Na} 2 \mathrm{C} 2 \mathrm{O} 4$ & \\
\hline $\mathrm{CaSO} 4$ & 0.1412 & $\mathrm{Na} 2 \mathrm{SO} 4$ & 0.1156 \\
\hline $\mathrm{MgO}$ & & $\mathrm{Fe}(\mathrm{NO} 3) 3$ & \\
\hline Coal-carbon & & $\mathrm{Si}(\mathrm{OH}) 4$ & \\
\hline NaTi2O5H & & $\mathrm{HCOOH}$ & \\
\hline \multirow[t]{3}{*}{ Total_1 } & 490.5552 & Total_2 & 124.9082 \\
\hline & & $\mathrm{H} 2 \mathrm{O}$ & 517.1523 \\
\hline & & Total & 1132.6157 \\
\hline
\end{tabular}


Table D- 7. Composition of SB10-9 Baseline Melter Feed at 1.5 GPM.

\begin{tabular}{|c|c|c|c|}
\hline Insoluble Solids & $\mathrm{lb} / \mathrm{hr}$ & Soluble Solids & $\mathrm{lb} / \mathrm{hr}$ \\
\hline $\mathrm{Fe}(\mathrm{OH}) 3$ & 103.6527 & $\mathrm{Ca}(\mathrm{COOH}) 2$ & \\
\hline $\mathrm{Al}(\mathrm{OH}) 3$ & 36.5090 & $\mathrm{Ca}(\mathrm{NO} 3) 2$ & 15.8231 \\
\hline $\mathrm{MnO} 2$ & & $\mathrm{Cu}(\mathrm{COOH}) 2$ & \\
\hline $\mathrm{Ca}(\mathrm{OH}) 2$ & & $\mathrm{Cu}(\mathrm{NO} 3) 2$ & \\
\hline $\mathrm{Mg}(\mathrm{OH}) 2$ & 0.3780 & $\mathrm{KCOOH}$ & \\
\hline $\mathrm{HgO}$ & 0.0083 & KNO3 & 1.1239 \\
\hline $\mathrm{Ni}(\mathrm{OH}) 2$ & 1.8241 & $\mathrm{Mg}(\mathrm{COOH}) 2$ & \\
\hline $\mathrm{Cr}(\mathrm{OH}) 3$ & 0.5167 & $\mathrm{Mg}(\mathrm{NO} 3) 2$ & 3.9443 \\
\hline $\mathrm{Cu}(\mathrm{OH}) 2$ & & $\mathrm{Mn}(\mathrm{COOH}) 2$ & 18.1184 \\
\hline $\mathrm{TiO} 2$ & 0.2804 & $\mathrm{Mn}(\mathrm{NO} 3) 2$ & \\
\hline $\mathrm{SiO} 2$ & 212.2828 & $\mathrm{NaCl}$ & 0.5163 \\
\hline $\mathrm{Na} 2 \mathrm{O}$ & 22.2792 & $\mathrm{NaF}$ & \\
\hline $\mathrm{Zn}(\mathrm{OH}) 2$ & 0.2198 & $\mathrm{NaCOOH}$ & 41.0757 \\
\hline $\mathrm{K} 2 \mathrm{O}$ & & NaNO3 & 57.0053 \\
\hline $\mathrm{RuO} 2$ & & $\mathrm{NaNO} 2$ & \\
\hline $\mathrm{RhO} 2$ & 0.1994 & $\mathrm{Na} 3 \mathrm{PO} 4$ & \\
\hline $\mathrm{PdO}$ & & $\mathrm{Ni}(\mathrm{COOH}) 2$ & \\
\hline $\mathrm{B} 2 \mathrm{O} 3$ & 22.2792 & $\mathrm{Ni}(\mathrm{NO} 3) 2$ & 0.5307 \\
\hline $\mathrm{Li} 2 \mathrm{O}$ & 22.2792 & $\mathrm{~Pb}(\mathrm{NO} 3) 2$ & 0.3127 \\
\hline $\mathrm{BaSO} 4$ & 0.7387 & $\mathrm{La}(\mathrm{COOH}) 3$ & \\
\hline $\mathrm{PbSO} 4$ & & $\mathrm{La}(\mathrm{NO} 3) 3$ & \\
\hline $\mathrm{Ce}(\mathrm{OH}) 3$ & & $\mathrm{Zn}(\mathrm{COOH}) 2$ & \\
\hline $\mathrm{La}(\mathrm{OH}) 3$ & & $\mathrm{Zn}(\mathrm{NO} 3) 2$ & 0.0218 \\
\hline $\mathrm{ZrO} 2$ & 1.1743 & $\mathrm{Na} 2 \mathrm{CO} 3$ & 0.0221 \\
\hline $\mathrm{CaCO} 3$ & & $\mathrm{Na} 2 \mathrm{C} 2 \mathrm{O} 4$ & \\
\hline $\mathrm{CaSO} 4$ & 1.8575 & $\mathrm{Na} 2 \mathrm{SO} 4$ & 0.9643 \\
\hline $\mathrm{MgO}$ & & $\mathrm{Fe}(\mathrm{NO} 3) 3$ & 2.9719 \\
\hline Coal-carbon & 9.6223 & $\mathrm{Si}(\mathrm{OH}) 4$ & 0.3299 \\
\hline NaTi2O5H & 10.2108 & $\mathrm{HCOOH}$ & \\
\hline \multirow[t]{3}{*}{ Total_1 } & 446.3124 & Total_2 & 142.7604 \\
\hline & & $\mathrm{H} 2 \mathrm{O}$ & 511.9979 \\
\hline & & Total & 1101.0707 \\
\hline
\end{tabular}




\section{Distribution:}
A. B. Barnes, 999-W
D. A. Crowley, 773-43A
S. D. Fink, 773-A
B. J. Giddings, 786-5A
C. C. Herman, 999-W
S. L. Marra, 773-A
F. M. Pennebaker, 773-42A
C. J. Bannochie, 773-42A
J. M. Gillam, 766-H
B. A. Hamm, 766-H
J. F. Iaukea, 704-30S
A. V. Staub, 704-27S
J. E. Occhipinti, 704-S
D. K. Peeler, 999-W
J. W. Ray, 704-S
H. B. Shah, 766-H
D. C. Sherburne, 704-S
M. E. Stone, 999-W

J. M. Bricker, 704-27S

T. L. Fellinger, 704-26S

E. W. Holtzscheiter, 704-15S

M. T. Keefer, 766-H

C. L. Atseff, 766-H

C. J. Johnson, 766-H

R. T. McNew, 766-H

S. C Shah, 766-H

A. Samadi-Dezfouli, 766-H

C. I. Aponte, 766-H

E. W. Daniel, 999-W

J. D. Newell, 999-W

A I. Fernandez, 999-W

D. C. Koopman, 999-W

J. M. Pareizs, 773-A

C. J. Bannochie, 773-42A

D. P. Lambert, 999-W

A. S. Choi, 773-42A

R. E. Eibling, 999-W 